Prepared in cooperation with the U.S. Environmental Protection Agency and the North Carolina Department of Environment and Natural Resources

\title{
Hydraulic Properties of the Surficial Aquifer at Five Selected Sites in the Little Contentnea Creek Basin, North Carolina, 2002-03
}

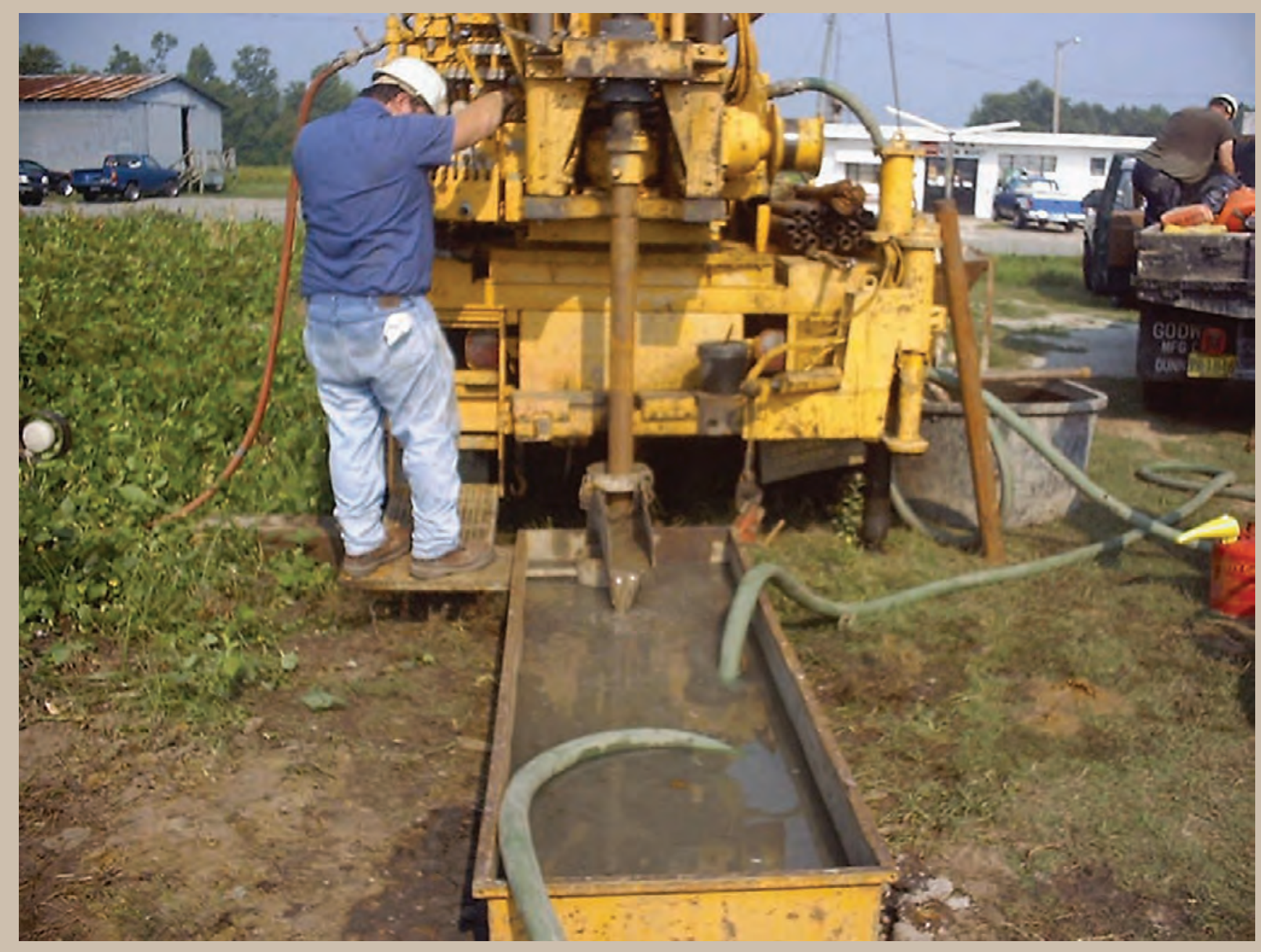

Scientific Investigations Report 2005-5238 
Cover. Truck-mounted drill rig used to install wells at aquifer-test sites in the Little Contentnea Creek basin, North Carolina. 


\section{Hydraulic Properties of the Surficial Aquifer at Five Selected Sites in the Little Contentnea Creek Basin, North Carolina, 2002-03}

By Douglas G. Smith and Melinda J. Chapman

Prepared in cooperation with the U.S. Environmental Protection Agency and the North Carolina Department of Environment and Natural Resources

Scientific Investigations Report 2005-5238 


\section{U.S. Department of the Interior \\ Gale A. Norton, Secretary \\ U.S. Geological Survey \\ P. Patrick Leahy, Acting Director}

U.S. Geological Survey, Reston, Virginia: 2005

For product and ordering information:

World Wide Web: http://www.usgs.gov/pubprod

Telephone: 1-888-ASK-USGS

For more information on the USGS--the Federal source for science about the Earth, its natural and living resources, natural hazards, and the environment:

World Wide Web: http://www.usgs.gov

Telephone: 1-888-ASK-USGS

Any use of trade, product, or firm names is for descriptive purposes only and does not imply endorsement by the U.S. Government.

Although this report is in the public domain, permission must be secured from the individual copyright owners to reproduce any copyrighted materials contained within this report.

Suggested citation:

Smith, D.G., and Chapman, M.J., 2005, Hydraulic properties of the surficial aquifer at five selected sites in the Little Contentnea Creek basin, North Carolina, 2002-03: U.S. Geological Survey Scientific Investigations Report 2005-5238, $104 \mathrm{p}$. 


\section{Contents}

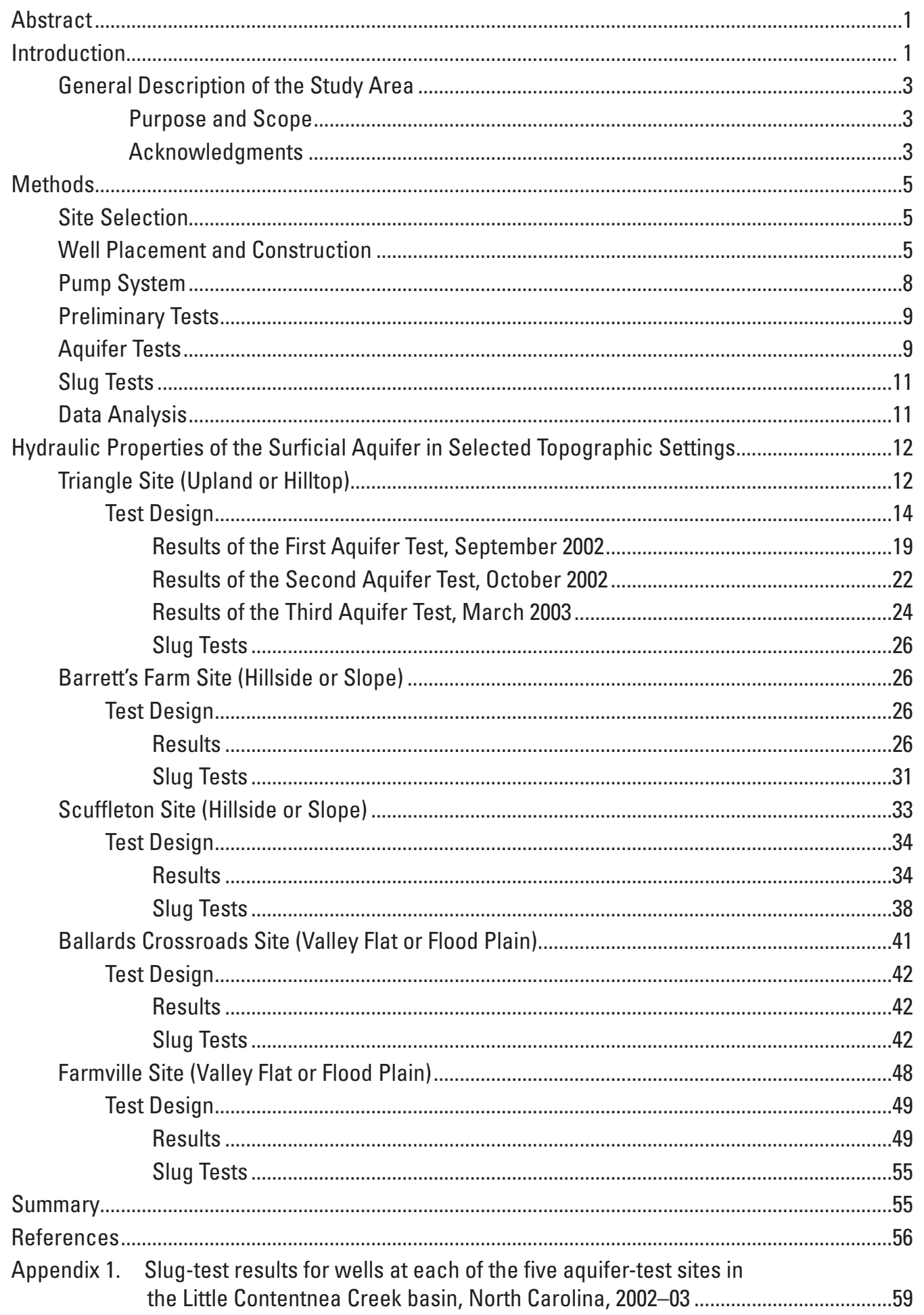




\section{Figures}

1. Locations of surficial aquifer-test study sites in the Little Contentnea Creek basin of North Carolina

2. Hydrogeologic cross section of area from Johnston County to Pamlico County, North Carolina .... .4

3. Photograph of truck-mounted drill rig used to install wells at aquifer-test sites ..............5

4. Photographs of $(A)$ North Carolina Geological Survey personnel collecting core samples at the Triangle aquifer-test site in the Little Contentnea Creek basin and (B) sediment samples after being placed in plastic-lined storage boxes.

5. Generalized illustration of typical well construction used for shallow and deep test wells

6. Photograph of an observation well being developed using compressed air in the Little Contentnea Creek basin

7. Photograph of trailer-mounted generator that was used to supply electricity to the pump and data-recording equipment at the aquifer-test sites in the Little Contentnea Creek basin.

8. Photograph of control box used to regulate variable-speed submersible pumps during preliminary pumping tests and aquifer tests conducted in the Little Contentnea Creek basin .

9. Graphical method used to determine sustainable pumping rate during preliminary testing

10. Photograph of instrumentation and recording equipment at the Triangle aquifer-test site in the Little Contentnea Creek basin

11. Maps showing locations of wells at the Triangle aquifer-test site in Greene County, North Carolina.

12. Photograph of water in roadside ditch about 70 feet north and west of test wells at the Triangle aquifer-test site

13. Field description of subsurface sediment layers and geophysical logs collected at the Triangle aquifer-test site in the Little Contentnea Creek basin

14. Photograph of instrument shelter atop concrete casing of abandoned residential well used for monitoring background water-level fluctuations during aquifer tests at the Triangle site.

15. Cartesian coordinates for the pumping well and observation wells at the Triangle site for the (A) first and second, and (B) third aquifer tests..

16. Drawdown data from observation wells during the first Triangle site aquifer test matched to the Neuman (1974) solution.

17. Moench (1997) type-curve overlay for the first Triangle site aquifer test........................21

18. Drawdown data from observation wells during the second Triangle site aquifer test matched to the Neuman (1974) solution.

19. Moench (1997) type-curve overlay for the second Triangle site aquifer test........

20. Drawdown data from observation wells during the third Triangle site aquifer test matched to the Neuman (1974) solution.

21. Moench (1997) type-curve overlay for the third Triangle site aquifer test. .25

22. Maps showing locations of wells at the Barrett's Farm aquifer-test site in Greene County, North Carolina.

23. Field description of subsurface sediment layers and geophysical logs collected at the Barrett's Farm aquifer-test site in the Little Contentnea Creek basin. 
24. Cartesian coordinates for the pumping well and observation wells at the Barrett's Farm aquifer-test site..

25. Drawdown data from observation wells during the Barrett's Farm aquifer test matched to the Neuman (1974) solution

26. Moench (1997) type-curve overlay for the Barrett's Farm site aquifer test.....................32

27. Maps showing locations of wells at the Scuffleton aquifer-test site in Pitt County, North Carolina

28. Field description of subsurface sediment layers and geophysical logs collected at the Scuffleton aquifer-test site in the Little Contentnea Creek basin

29. Cartesian coordinates for the pumping well and observation wells at the Scuffleton aquifer-test site.

30. Graph of water level in Scuffleton pumping well MFW-1A showing an increased rate of drawdown after reaching about 20 feet below land surface in the Little Contentnea Creek basin

31. Drawdown data from observation wells during the Scuffleton site aquifer test matched to the Neuman (1974) solution.

32. Moench (1997) type-curve overlay for the Scuffleton site aquifer test. .40

33. Maps showing locations of wells at the Ballards Crossroads aquifer-test site in Pitt County, North Carolina

34. Field description of subsurface sediment layers and geophysical logs collected at the Ballards Crossroads aquifer-test site in the Little Contentnea Creek basin.......

35. Cartesian coordinates for the pumping well and observation wells at the Ballards

Crossroads aquifer-test site.

36. Drawdown data from observation wells during the Ballards Crossroads aquifer test matched to the Neuman (1974) solution.

37. Moench (1997) type-curve overlay for the Ballards Crossroads site aquifer test...........47

38. Maps showing locations of wells at the Farmville aquifer-test site in Pitt County, North Carolina

39. Field description of subsurface sediment layers and geophysical logs collected at the Farmville aquifer-test site in the Little Contentnea Creek basin

40. Cartesian coordinates for the pumping well and observation wells at the Farmville aquifer-test site

41. Drawdown data from observation wells during the Farmville site aquifer test matched to the Neuman (1974) solution.

42. Moench (1997) type-curve overlay for the Farmville site aquifer test

\section{Tables}

1. Descriptions of wells used in the aquifer tests at the Triangle site in the Little Contentnea Creek basin of North Carolina.

2. Transmissivity, hydraulic conductivity, and specific yield estimates for aquifer tests conducted in the Little Contentnea Creek basin of North Carolina.

3. Descriptions of wells used in the aquifer test at the Barrett's Farm site in the Little Contentnea Creek basin of North Carolina 
4. Descriptions of wells used in the aquifer test at the Scuffleton site in the Little Contentnea Creek basin of North Carolina...

5. Descriptions of wells used in the aquifer test at the Ballards Crossroads site in the Little Contentnea Creek basin of North Carolina.

6. Descriptions of wells used in the aquifer test at the Farmville site in the Little Contentnea Creek basin of North Carolina.

\section{Conversion Factors, Datums, and Acronyms and Abbreviations}

\begin{tabular}{|c|c|c|}
\hline Multiply & By & To obtain \\
\hline \multicolumn{3}{|c|}{ Length } \\
\hline inch (in.) & 25.4 & millimeter (mm) \\
\hline foot $(\mathrm{ft})$ & 0.3048 & meter $(\mathrm{m})$ \\
\hline mile (mi) & 1.609 & kilometer (km) \\
\hline \multicolumn{3}{|c|}{ Area } \\
\hline square foot $\left(\mathrm{ft}^{2}\right)$ & 0.0929 & square meter $\left(\mathrm{m}^{2}\right)$ \\
\hline square mile $\left(\mathrm{mi}^{2}\right)$ & 2.590 & square kilometer $\left(\mathrm{km}^{2}\right)$ \\
\hline \multicolumn{3}{|c|}{ Volume } \\
\hline gallon (gal) & 3.785 & liter (L) \\
\hline \multicolumn{3}{|c|}{ Flow } \\
\hline foot per day $(\mathrm{ft} / \mathrm{d})$ & 0.3048 & meter per day (m/d) \\
\hline gallon per minute (gal/min) & 0.06309 & liter per second (L/s) \\
\hline \multicolumn{3}{|c|}{ Transmissivity } \\
\hline foot squared per day $\left(\mathrm{ft}^{2} / \mathrm{d}\right)$ & 0.0929 & meter squared per day $\left(\mathrm{m}^{2} / \mathrm{d}\right)$ \\
\hline
\end{tabular}

Vertical Datum: In this report, vertical coordinate information is referenced to the National Geodetic Vertical Datum of 1929 (NGVD 29).

Horizontal Datum: In this report, horizontal coordinate information is referenced to the North American Datum of 1983 (NAD 83).

\section{Acronyms and Abbreviations:}

$\mathrm{NC}$

North Carolina

NCDENR North Carolina Department of Environment and Natural Resources

NCGS

PVC North Carolina Geological Survey

USEPA U.S. Environmental Protection Agency

USGS

WD

U.S. Geological Survey

WDP well-bore storage delayed drawdown response 


\title{
Hydraulic Properties of the Surficial Aquifer at Five Selected Sites in the Little Contentnea Creek Basin, North Carolina, 2002-03
}

\author{
By Douglas G. Smith and Melinda J. Chapman
}

\section{Abstract}

Aquifer tests of the surficial aquifer were conducted from June 2002 to June 2003 at selected sites in the Little Contentnea Creek drainage basin in the Coastal Plain Physiographic Province of North Carolina. These tests were designed to evaluate the variability of unconfined, surficial aquifer properties at selected sites across the Little Contentnea Creek basin and determine if relations exist between the hydraulic properties of the surficial aquifer and the topographic setting. Five sites were tested in three generalized topographic or geomorphic settings — upland or hilltop (one site), hillside or slope (two sites), and valley flat or flood plain (two sites).

Each aquifer test was conducted by continuously pumping water from the surficial aquifer at a constant rate for a period of 24 to 72 hours. For each test, water was withdrawn from one well that was constructed to fully penetrate the surficial aquifer. Water levels were measured in the pumping well and in multiple observation wells at each test site. Pumping rates for the five aquifer tests ranged from 1.8 to 13.6 gallons per minute. Water-table depths measured under static conditions at the five test sites ranged from about 1.4 to 10.8 feet below land surface. The saturated thickness of the surficial aquifer at most test sites generally was less than 19 feet, and the lower boundary of the surficial aquifer (top of the uppermost confining layer) generally was less than 25 feet below land surface.

Estimates of transmissivity at the five test sites ranged from 55 to 500 feet squared per day. Hydraulic conductivity values were not estimated from aquifer-test data because of the large reductions in saturated thickness, which ranged from about 25 to 56 percent. Based on slug tests, hydraulic conductivity estimates at the five test sites ranged from 3 to 21 feet per day. Specific yields calculated for the test sites ranged from less than 1 percent to 10 percent. The lowest estimated transmissivity ( 55 feet squared per day) was determined for a site that was located in a valley-flat setting. The highest estimated transmissivity (500 feet squared per day) determined during this investigation was at one of the hillside sites. The lowest estimated hydraulic conductivity was determined for one of the hillside settings. The highest hydraulic conductivity estimate determined was at one of the valley-flat sites. Using results from the five sites tested in the Little Contentnea Creek basin, no relation was identified between topographic setting and hydraulic properties of the surficial aquifer.

\section{Introduction}

In 1999, the U.S. Geological Survey (USGS) began an investigation in cooperation with the U.S. Environmental Protection Agency (USEPA) and the North Carolina Department of Environment and Natural Resources (NCDENR) of the movement and characteristics of nitrogen in ground water in the Coastal Plain Physiographic Province of North Carolina (fig. 1). The investigation was conducted at a 0.57 -square-mile $\left(\mathrm{mi}^{2}\right)$ site in Greene County near Lizzie, North Carolina (Lizzie Research Station, fig. 1). This study area, located a few miles south of the town of Farmville, is in the drainage basin of Sandy Run, a tributary to Little Contentnea Creek. The Little Contentnea Creek basin drains about 18 percent of the Contentnea Creek basin, which in turn drains into the Neuse River. Contentnea Creek has been identified as a major contributor of both nitrogen and phosphorus to the Neuse River (Spruill and others, 1998).

Since 1999, various types of hydrologic data have been collected, and a large number of ground-water wells have been installed at the Lizzie Research Station. As part of the project, hydraulic properties of the shallow and deep aquifer systems have been studied at the Lizzie site. Some of the deep aquifers studied underlie large areas of the Coastal Plain and commonly serve as public water-supply sources. As a result, the hydraulic properties of these deep aquifers have been studied in many other areas of the Coastal Plain. In contrast, much less information is available about the surficial aquifer of the Coastal Plain. Although the surficial aquifer has been studied at the Lizzie site, hydraulic properties of the surficial aquifer in other areas of the Coastal Plain are largely unknown. Because ground water is estimated to contribute 50 percent or more of the total annual flow in Coastal Plain streams 


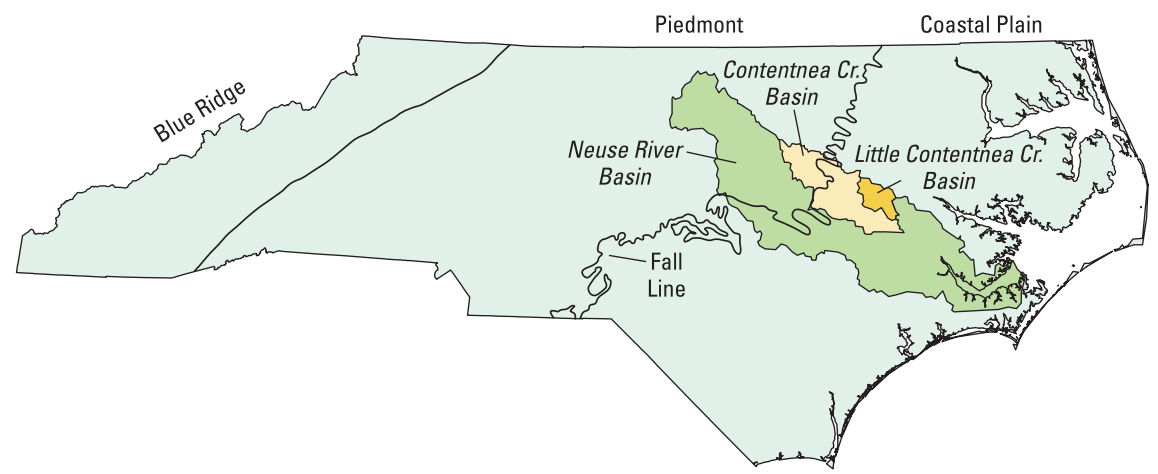

LOCATIONS OF PHYSIOGRAPHIC PROVINCES, NEUSE RIVER BASIN, CONTENTNEA CREEK BASIN, AND LITTLE CONTENTNEA CREEK BASIN IN NORTH CAROLINA

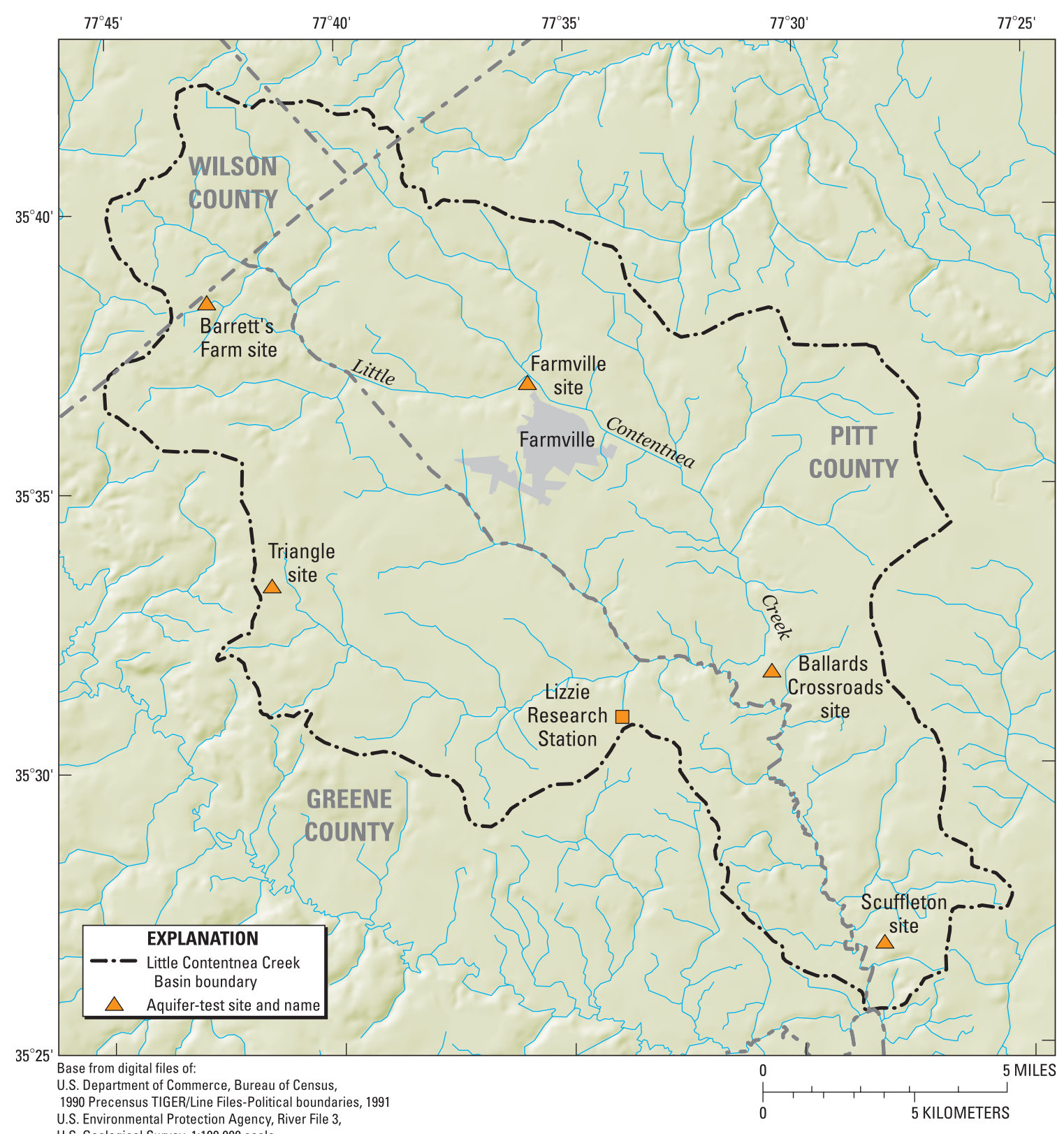

Figure 1. Locations of surficial aquifer-test study sites in the Little Contentnea Creek basin of North Carolina. 
(McMahon and Lloyd, 1995; Spruill and others, 1998), a more regional understanding of the relation between the surficial aquifer and streams in the Neuse River basin is needed by water-resources scientists and managers.

To define hydraulic characteristics of the surficial aquifer on a larger scale, the USGS in cooperation with the NCDENR conducted an investigation of the surficial aquifer at selected sites in the Little Contentnea Creek basin. Tests of the surficial aquifer were conducted at five selected sites from June 2002 to June 2003. The test results were compared to identify possible relations between topographic setting and surficial aquifer properties.

\section{General Description of the Study Area}

The study area in the Little Contentnea Creek drainage basin encompasses a large part of Pitt and Greene Counties and a smaller area in Wilson County (fig. 1). The Little Contentnea Creek basin covers an area of about $181 \mathrm{mi}^{2}$ and includes elevations ranging from about 118 to 20 feet (ft) above National Geodetic Vertical Datum of 1929 (NGVD 29; Farrell and others, 2003). Terrain in the study area generally consists of a "....series of paleoshorelines and intervening terraces that step down in elevation and age toward the coast and into drainages" (Farrell and others, 2003). All of the aquifer-test sites are located in the Wicomico Plain, a relict marine terrace described by Daniels and others (1984) and more recently by Ator and others (in press).

The Little Contentnea Creek basin receives an average of 49 inches of precipitation annually (Southeast Regional Climate Center, 2002). It should be noted that climatic extremes occurred during the course of this study, which may have affected the results. A prolonged drought occurred from 1998 to 2002 and resulted in lower-than-normal ground-water levels. In contrast, above-normal rainfall occurred in early 2003, which resulted in higher ground-water levels in the study area.

The geology of the Little Contentnea Creek basin is composed primarily of sedimentary rock and unconsolidated sediment layers. The basin lies in the central Coastal Plain area, which was described by Heath (1980) as having "numerous thin layers of water-bearing sand complexly interbedded with clay." The near-surface sediments are composed of unconsolidated sands, silts, and clays. Deeper sediment layers in the area commonly consist of a mixture of sand, clay, and silt particles. Over time, the area has been affected by multiple sea-level transgressions and regressions; as a result, the properties of near-surface and deeper sediment layers can vary substantially from place to place.

The hydrogeology of the Little Contentnea Creek basin is thought to be similar to that shown in cross section B-B' in figure 2, which extends across the Coastal Plain region south of the study area from Johnston County to Pamlico County. In general, the hydrogeologic framework of the area consists of an unconfined, near-surface, shallow aquifer that is underlain by several deeper confined aquifers. In this report, the unconfined, shallow aquifer is referred to as the surficial aquifer. In rural parts of the study area, the surficial aquifer serves as a source of domestic drinking water. Some public-supply systems and industries in the area withdraw water from the deeper confined aquifers for water supply.

\section{Purpose and Scope}

This report presents the results of surficial aquifer tests conducted in three topographic settings in the Little Contentnea Creek drainage basin from June 2002 to June 2003. The focus of the study was limited to the surficial aquifer, and the results are intended to enhance previous aquifer studies conducted at the Lizzie Research Station in the Little Contentnea Creek basin (H.E. Mew, Jr., North Carolina Department of Environment and Natural Resources, written commun., 2002). The aquifer-test results also can be used to improve understanding of the ground-water and surface-water interactions in the Coastal Plain of North Carolina. Although largely controlled by sediment and geologic characteristics, hydraulic properties from each aquifer test were compared to determine if relations exist between the hydraulic properties of the surficial aquifer and topographic setting.

A total of six sites were selected for testing with two sites located in each of three generalized topographic or geomorphic settings-upland or hilltops, hillsides or slopes, and valley-flat or flood-plain settings. Because of problems with equipment and limited site access, one test site in an upland area near the Lizzie Research Station was abandoned, and aquifer tests at only five of the six selected sites were completed.

\section{Acknowledgments}

The authors thank the many landowners in Greene, Pitt, and Wilson Counties who graciously and generously allowed access to their private properties in order to conduct this investigation. The authors also thank the following NCDENR personnel for their help in well drilling and conducting the aquifer tests during this investigation: Timothy Hill, Bill Todd, Jessie Martin, Thomas King, Dennis Foyles, Billy Casper, and Kevin Bubak; and the following NCDENR personnel who assisted in the data-collection activities during each of the aquifer tests: David Eudy, Walt Haven, the late Ted Mew, and Ray Milosh. Further thanks are extended to Kathleen M. Farrell and Amy Keyworth of the North Carolina Geological Survey for collecting core samples and providing detailed descriptions of sediment layers at each test site. The authors appreciate assistance provided by Brad Huffman of the USGS with instrumentation and field operations during each aquifer test. Special thanks are extended to Ronald W. Coble (USGS retired), who offered valuable guidance throughout the course of this investigation. In addition, the authors thank Edwin 


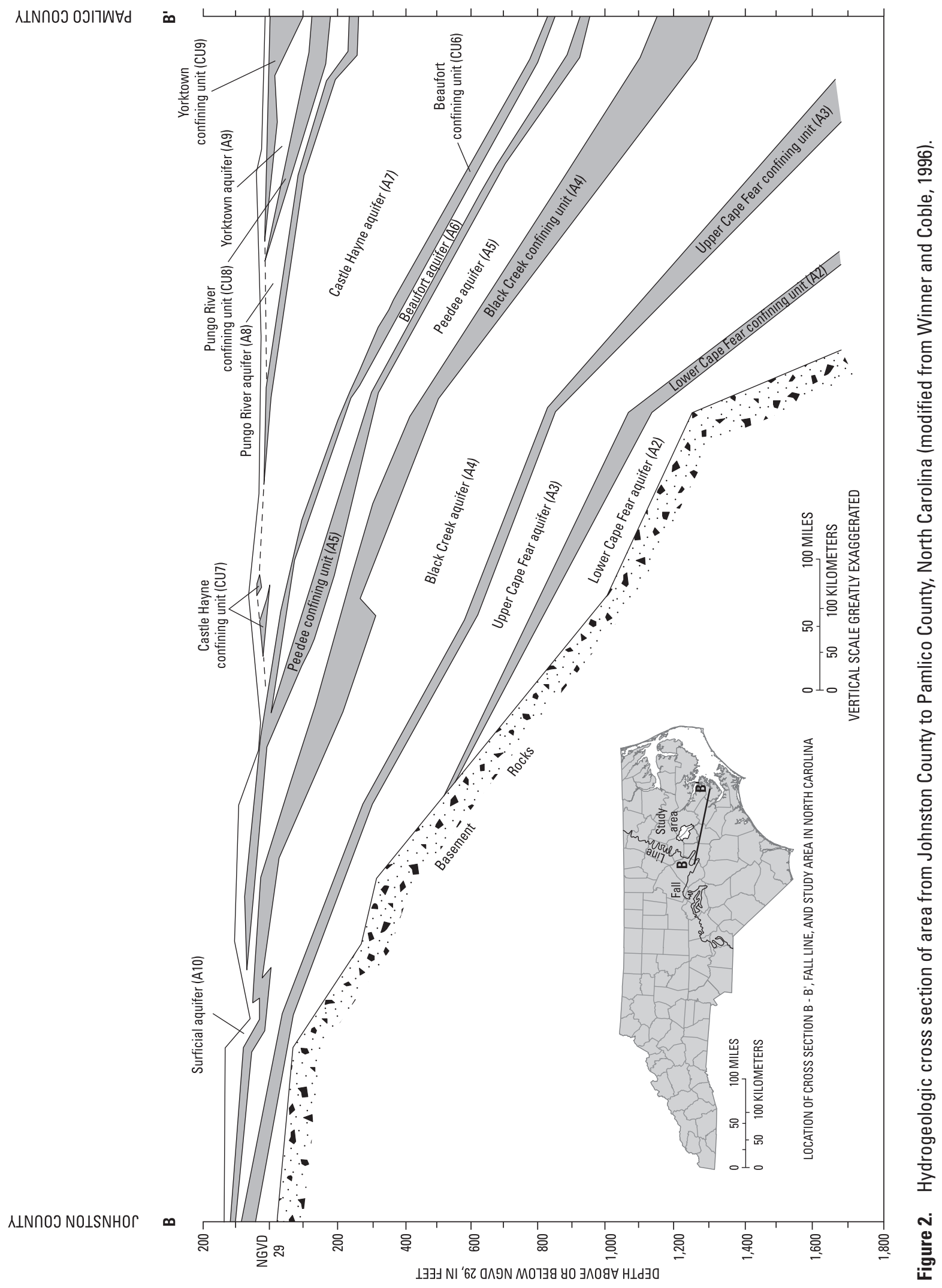


Weeks of the USGS Branch of Regional Research, Central Region, in Lakewood, Colorado, for his insight and guidance with the analyses of the aquifer-test data.

\section{Methods}

The methods used to select sites, install wells, conduct the aquifer tests, and analyze the data collected at the five study sites are presented here.

\section{Site Selection}

Areas in the Little Contentnea Creek drainage basin that were located on hilltops, hillsides, and valley bottoms were considered for testing. Because the North Carolina Geological Survey (NCGS) was conducting a concurrent stratigraphic investigation in the study area, sites that were near proposed NCGS study areas were given first consideration. During the initial field reconnaissance, areas were identified near the proposed NCGS study sites and in targeted topographic settings that were accessible by heavy equipment. Final site selection was based on topographic setting, accessibility, proximity to NCGS study areas, hydrologic conditions, and spatial distribution within the Little Contentnea Creek drainage basin. After selecting potential test sites, permission to gain access to the sites was obtained from the landowners. During the course of this study, preliminary investigations were conducted at
11 sites. Ultimately, 5 of the 11 sites were not tested because of the unsuitable nature of physical or hydrologic conditions at the sites.

\section{Well Placement and Construction}

At each site, a core of sediment samples was collected to determine the depth and thickness of the surficial aquifer. These samples were collected from a test hole drilled at each site using a truck-mounted drill rig (fig. 3) equipped with a wire-line core barrel and hollow-stem auger. As each test hole was drilled, the hollow-stem auger cut away the surrounding sediments leaving an undisturbed core in the hollow center of the auger. As the auger progressed deeper into the ground, the undisturbed sediments in the core were encapsulated by a removable steel core barrel that was placed inside the auger. Samples were collected from the core barrel at 5-ft increments as drilling continued (fig. 4). Drilling fluid composed of bentonite mud slurry was used at each site to prevent collapse and to maintain the integrity of the core hole wall during the collection of sediment samples. At each test site, the collection of core samples proceeded considerably beyond the lower boundary of the surficial aquifer to support the concurrent stratigraphic investigation conducted by the NCGS in the Little Contentnea Creek basin.

All core samples collected during this investigation were taken to the NCGS office in Raleigh, North Carolina, for further analysis and storage. Geophysical logs, including natural gamma, resistivity, and electrical conductivity, were

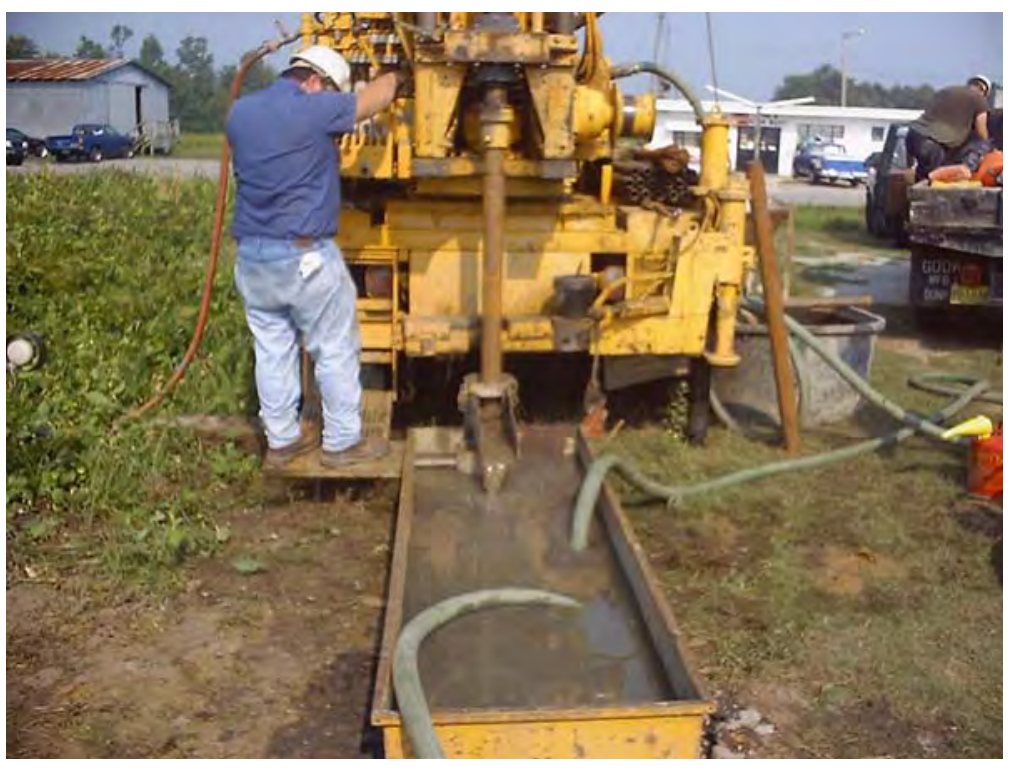

Figure 3. Truck-mounted drill rig used to install wells at aquifer-test sites (photograph by D.G. Smith, U.S. Geological Survey, 2002). 
A.

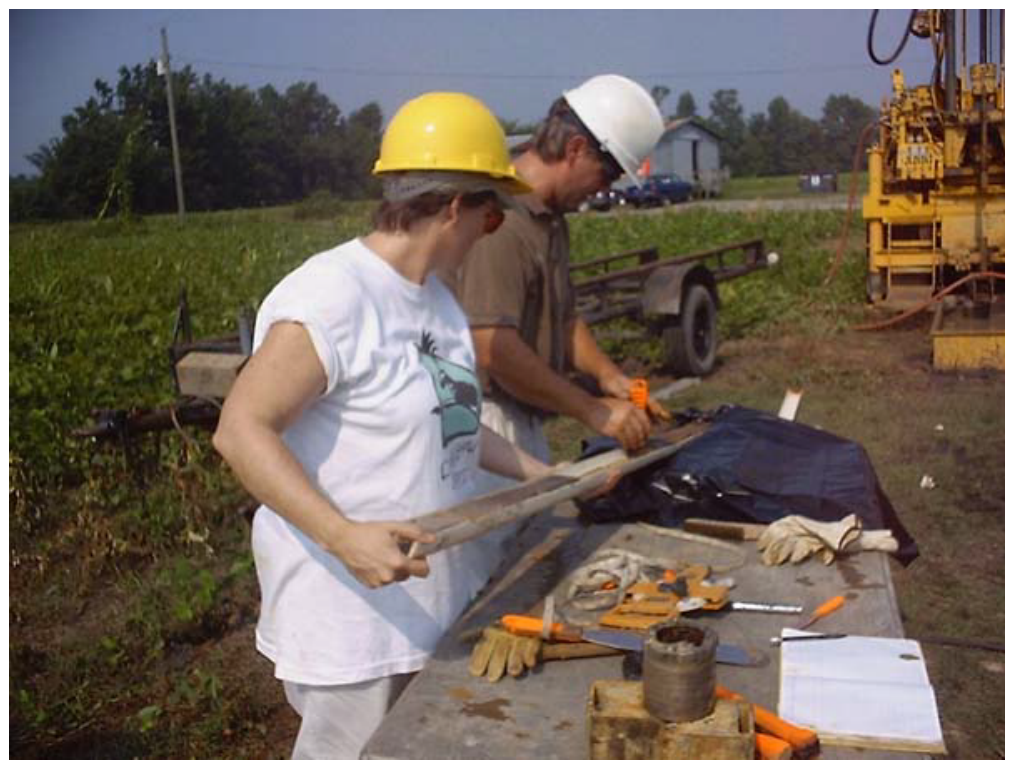

B.

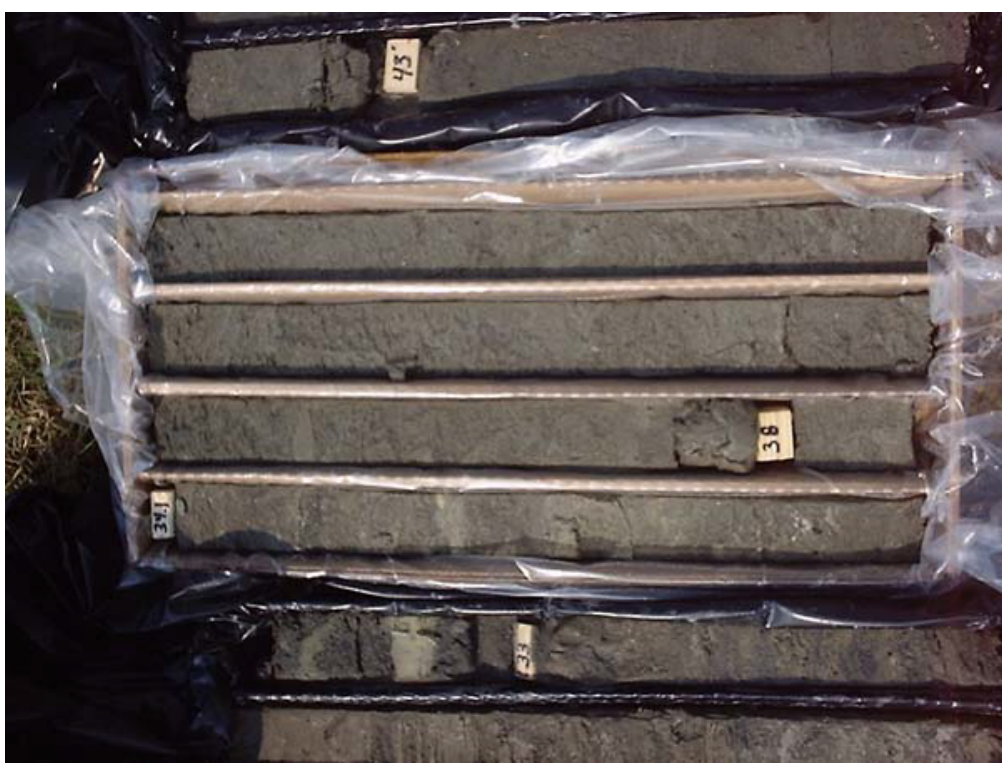

Figure 4. (A) North Carolina Geological Survey personnel collecting core samples at the Triangle aquifer-test site in the Little Contentnea Creek basin and (B) sediment samples after being placed in plastic-lined storage boxes (photograph by D.G. Smith, U.S. Geological Survey, 2002).

collected by NCDENR or USGS personnel. Copies of the geophysical well logs for each test site are on file at the USGS North Carolina Water Science Center in Raleigh.

During this investigation, five sites were abandoned and eliminated from consideration for further testing. The core samples collected at each of these sites indicated extensive near-surface clay layers and limited water-bearing sediments. With insufficient quantities of water available in the surficial aquifer, these sites were considered unsuitable for conducting aquifer tests.

At the remaining sites selected for testing, the core hole produced by coring was used to install a deep observation well. These deep wells generally were constructed by placing a length of well casing into the deeper zones of the core hole (fig. 5). A section of slotted well screen was attached to the top of the lower length of casing. At most sites the screen of 
TYPICAL WELL CONSTRUCTION

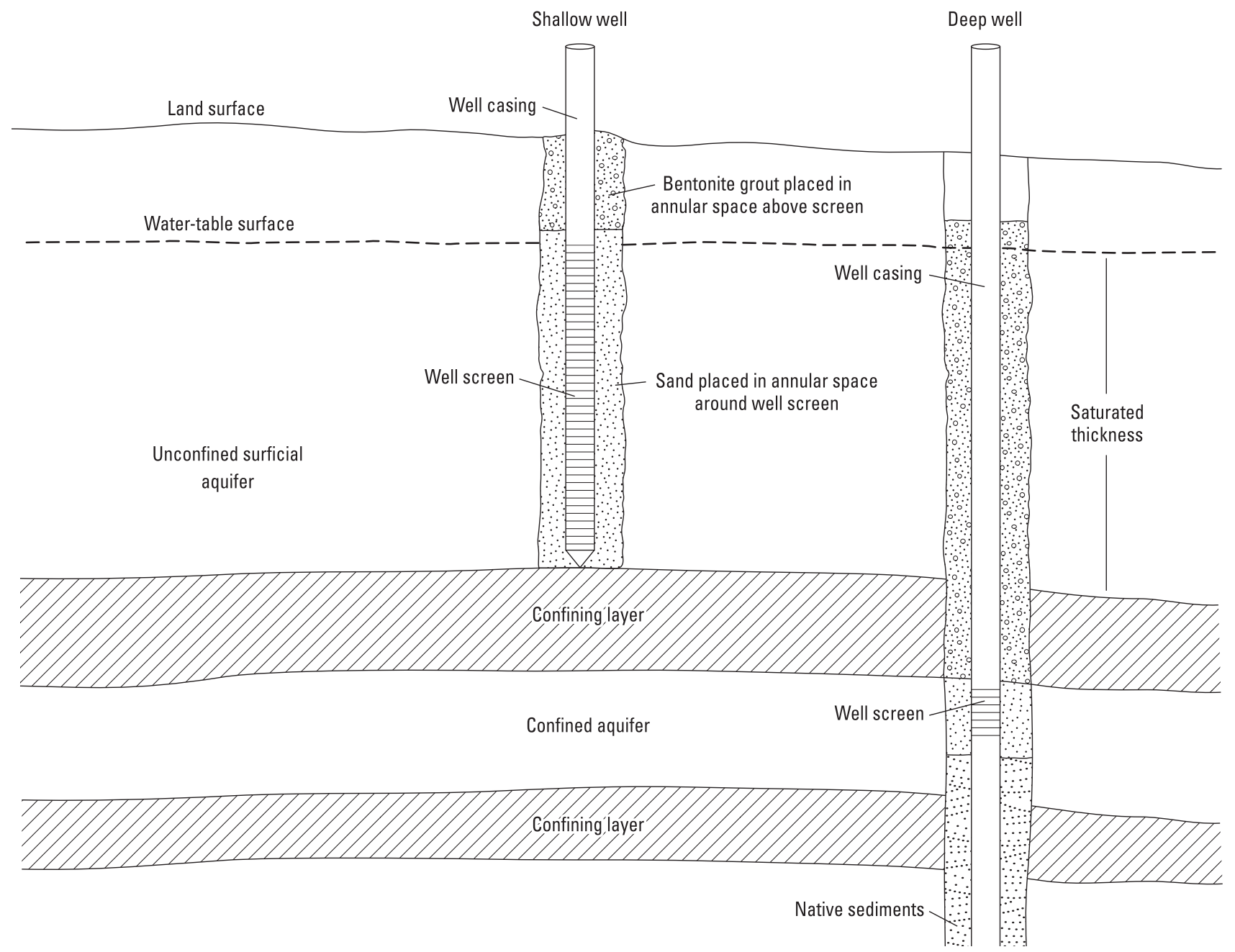

Figure 5. Generalized illustration of typical well construction used for shallow and deep test wells.

the deep well was placed directly beneath the confining unit of the surficial aquifer (fig. 5). Another length of well casing was attached to the top of the screen to extend the well above land surface. In these deeper wells, bentonite grout was placed in the annular space above the screen to isolate the screened zone from the surficial aquifer. Water-level data collected from the deeper wells were used to indicate the general amount of interconnection between the surficial aquifer and deeper sediments but were not used to quantify hydraulic properties.

After collecting core samples and installing the relatively deep well, at least five shallow wells were installed at each test site by using a truck-mounted drill rig and hollow-stem augers. One of the shallow wells at each site was designed and constructed to serve as the pumping well during an aquifer test. All of the shallow wells were constructed to fully penetrate the surficial aquifer. The shallow wells generally were installed in an " $X$ " pattern, with the pumping well in the center and shallow observa- tion wells drilled at varied distances from the pumping well. At most sites, the shallow observation wells were installed approximately $5,10,15$, and $20 \mathrm{ft}$ from the pumping well. The distance between the deep well and the pumping well was different at each site.

All observation wells were constructed by using 2-inchdiameter polyvinyl chloride (PVC) casing and \#10-slot (0.010-inch openings) screens with fine sand and(or) native sediments placed in the annular space of the screened interval. The pumping well at each site was constructed of 4-inchdiameter PVC using a \#20-slot (0.020-inch openings) well screen with a coarse sand pack placed in the annular space of the screened interval. Above the screened interval of each well, bentonite grout was used to backfill the annular space (fig. 5).

Compressed air was used to develop the wells at each test site. At most test sites, a large trailer-mounted air compressor was used to provide compressed air. After placing the air hose near the well bottom, the volume of air flow was set to 
produce periodic expulsion of water from the well casing (fig. 6). The air introduced into the well created turbulence and increased pressure, which raised the water level in the well and served to clear the screen openings of fine sediments. To further clear well screens, the air supply was periodically pinched-off near the compressor. By this method, air pressure was surged in the well to further clear the screen openings and assure a good connection with the aquifer.

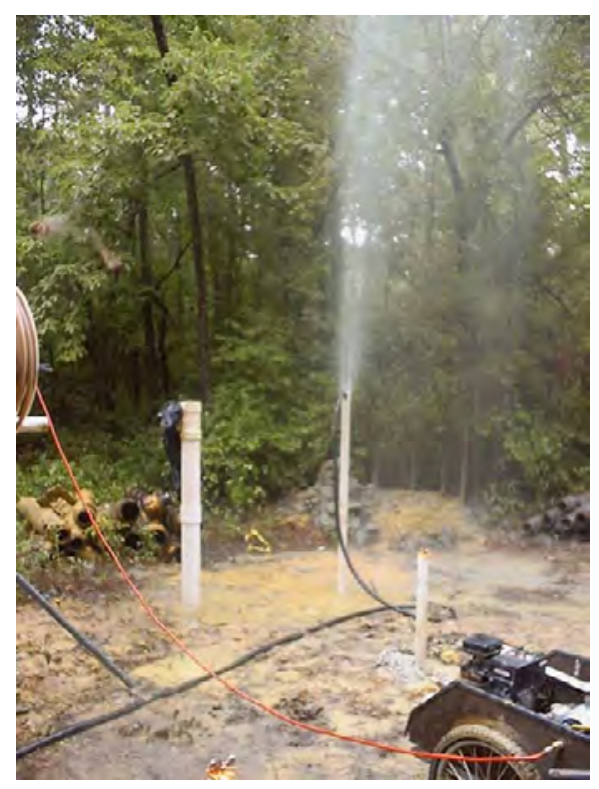

Figure 6. An observation well being developed using compressed air in the Little Contentnea Creek basin (photograph by D.G. Smith, U.S. Geological Survey, 2002).

All wells were installed and developed by personnel from the NCDENR Groundwater Section using NCDENRprovided equipment, supplies, and materials. USGS personnel were onsite during most of the drilling activities to assist NCGS personnel in collecting core samples and to document well construction.

\section{Pump System}

Aquifer tests and preliminary testing at each site were conducted by using an electric, variable-speed submersible pump that was regulated by a specifically designed control box. A diesel-powered trailer-mounted generator supplied electricity to the pump (fig. 7). A low-volume, variable-speed, submersible pump (rated from 0 to 7 gallons per minute (gal/min)) was used at four of the test sites. A similarly designed but higher-volume variable-speed submersible pump (rated from 0 to $50 \mathrm{gal} / \mathrm{min}$ ) was used at the Scuffleton test site to withdraw $13.6 \mathrm{gal} / \mathrm{min}$.

During preliminary testing at each site, the control box was used to adjust the speed of the pump. The variable-speed pump and digital control-box system allowed precise adjustments to the pump speed during preliminary testing and also provided a constant low-volume pumping rate throughout each aquifer test. To define flow rates, manual volumetric measurements of pump discharge were made at least hourly during each aquifer test. These volumetric measurements were made using a stopwatch and a graduated plastic bucket. The bucket used for volumetric measurements had been carefully marked to a volume of 5.02 gallons by using a graduated cylinder. To further verify pumping rates, a digital flowmeter rated from 2 to $20 \mathrm{gal} / \mathrm{min}$ was used to monitor the pump discharge. Throughout the duration of each aquifer test, with the exception of the first two tests at the Triangle site (fig. 1), the flowmeter was used to verify that the pumping rate remained constant. The flowmeter was designed to provide accurate readings within 1 percent. During each aquifer test, all volumetric flow measurements were systematically documented in field notes. Observed flowmeter readings also were documented.

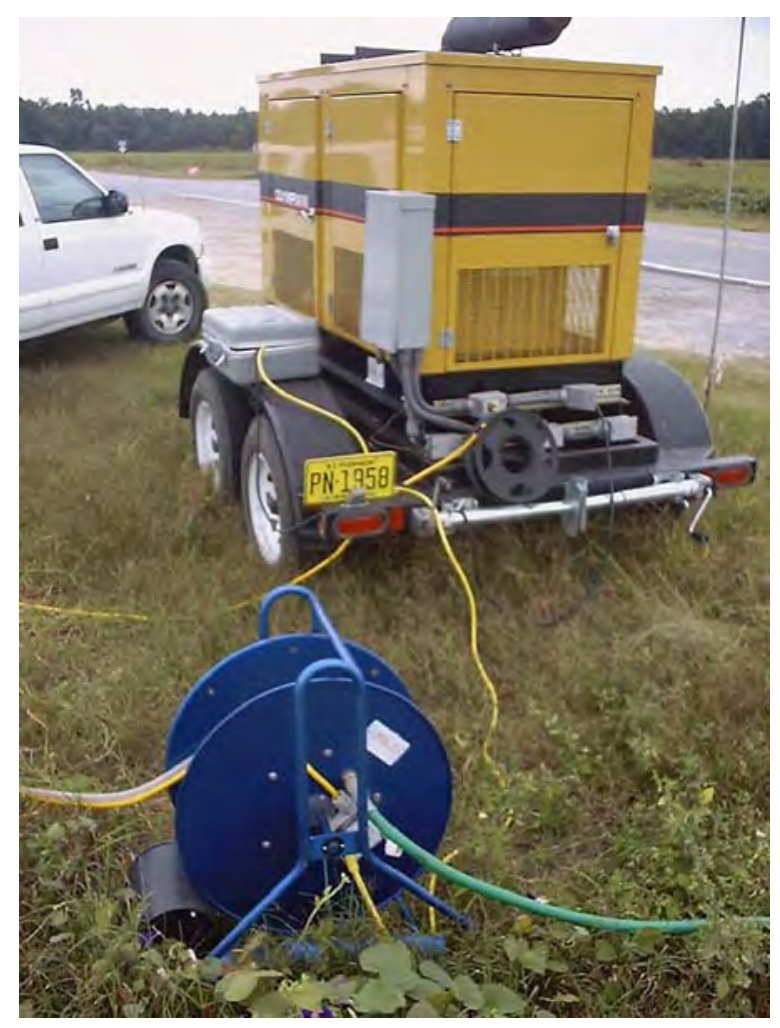

Figure 7. The trailer-mounted generator that was used to supply electricity to the pump and datarecording equipment at the aquifer-test sites in the Little Contentnea Creek basin (photograph by D.G. Smith, U.S. Geological Survey, 2002). 
Throughout this investigation, flowmeter and volumetric readings were consistently in agreement with values differingeless than 8.2 percent. During one aquifer test and other preliminary testing, sediment particles became lodged in moving parts of the flowmeter, which caused the meter to under-register the actual pumping rate. As a result of this potential for sediment-induced problems with the flowmeter, all pumping rates presented in this report are based on the volumetric measurements. Pumping rates were held constant during each aquifer test in accordance with USGS guidelines (Stallman, 1971).

\section{Preliminary Tests}

After the wells were installed and developed, a preliminary pumping test was conducted at each site to determine a pumping rate that could be sustained for the duration of an aquifer test. While developing wells at each test site, the driller estimated the yield of the well designated for pumping. This estimate of well yield was then used as a guide for pump-rate settings in the preliminary test. At the beginning of each preliminary test, the pump was set to withdraw water at a rate below the driller's estimate of yield. Over the course of a preliminary test, the pumping rate was periodically increased by using the control box in conjunction with the variablespeed pump (fig. 8). Eventually, a satisfactory pumping rate was reached at each test site and the control-box setting used to produce the desired pumping rate was documented.

During preliminary tests, water levels were measured in the pumping well and in some observation wells. Water-level measurements from the pumping well were plotted by hand in the field on semilog graph paper. Changes made to the pumping rate produced changes in the rate of drawdown in the pumping well. Immediately following an increase in the pumping rate, water levels in the pumping well fell rapidly. After several minutes, the rate of drawdown in the pumping well decreased and became more constant (fig. 9). Assuming that the reduced rate of drawdown would remain constant, the plotted line of water-level measurements from the pumping well was projected across the time scale on the semilog graph. At each test site, this projected line was used to estimate the amount of drawdown that could be expected in a pumping well after 72 hours of pumping (fig. 9) during an aquifer test. Using the projected graph of long-term drawdown, pumping rates were adjusted until a sustainable pumping rate was reached that would provide sufficient stress on the aquifer without overpumping the pumping well. The final pumping rate determined by preliminary testing was documented for each site and subsequently used to conduct the aquifer test.

Manipulating the length of discharge hose placed on the outlet side of the variable-speed pumps substantially affected the pumping rate. In addition to using the variable-speed pump and control-box system, the pumping rate was tailored for most preliminary tests by varying the length of the discharge hose. During preliminary tests at each site, pumping rates were monitored with a flowmeter and verified by volumetric measurements.

\section{Aquifer Tests}

The aquifer tests were conducted several days after the preliminary tests were completed. An aquifer test was conducted at each site by continuously pumping water from one well completed in the surficial aquifer for a period of

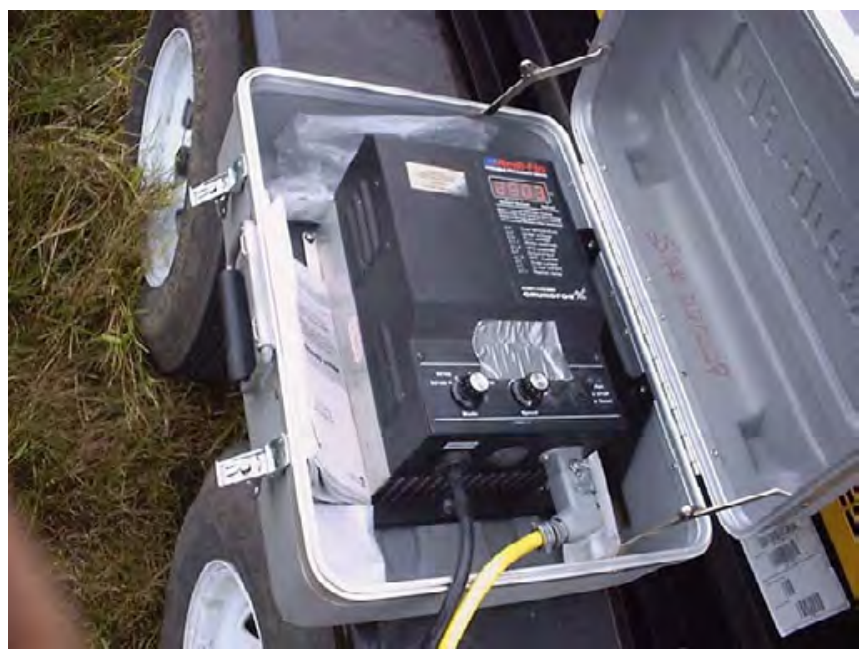

Figure 8. Control box used to regulate the variable-speed submersible pumps during preliminary pumping tests and aquifer tests conducted in the Little Contentnea Creek basin (photograph by D.G. Smith, U.S. Geological Survey, 2002). 


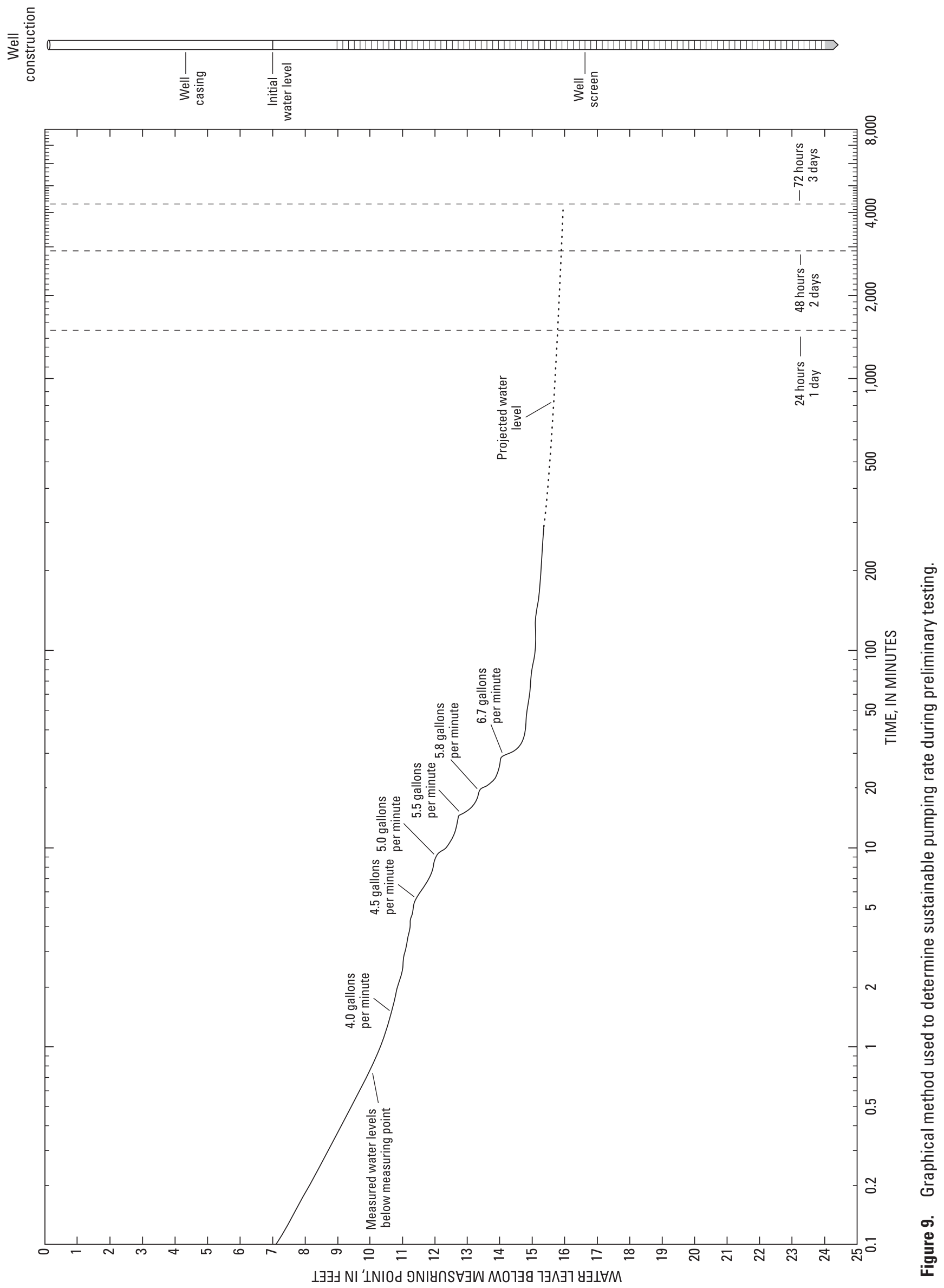


24 to 72 hours. All tests completed for this investigation were conducted while maintaining a constant pumping rate. The pumping well was pumped at a rate determined by preliminary testing at each site. During aquifer tests, water levels were monitored in the pumping well and in multiple observation wells. Because of funding constraints, aquifer tests conducted in the latter phases of this investigation were of shorter duration than the earlier tests.

Water levels in the pumping well and in all observation wells were recorded during the aquifer tests using submersible pressure transducers and an electronic data logger furnished by NCDENR (fig. 10). A laptop computer connected to the data logger was used to store aquifer-test data. A trailer-mounted generator was used to supply electric power to the laptop and recording equipment (fig. 7). To verify the accuracy of pressure-transducer readings, water levels also were measured using steel or electric tapes throughout the duration of each aquifer test. Water-level measurements were recorded at relatively short time intervals near the beginning of each test and during the early recovery phase at the end of each test. Background water levels also were monitored in a nearby shallow well throughout the duration of each aquifer test.

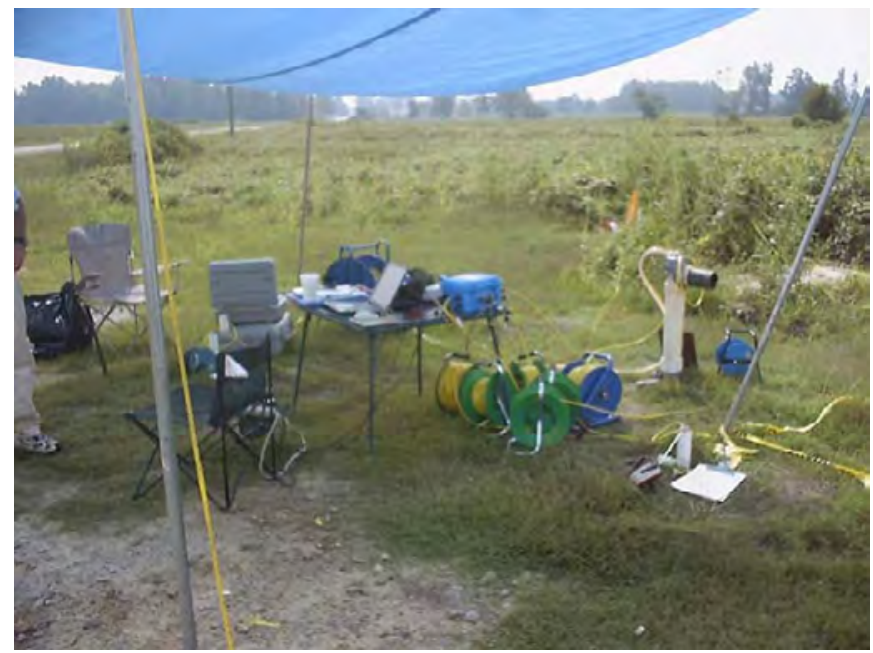

Figure 10. Instrumentation and recording equipment at the Triangle aquifer-test site in the Little Contentnea Creek basin (photograph by D.G. Smith, U.S. Geological Survey, 2002).

\section{Slug Tests}

Rising- and falling-head slug tests were conducted in wells at each aquifer-test site to derive an estimate of hydraulic conductivity (appendix 1). Solid slugs were used to displace water inside the wells. One of three solid slugs was used to conduct the slug tests-a 5-ft-long, 1.0-inch-diameter solid slug; a 5-ft-long, 2.5-inch-diameter solid slug; or a 3-ft-long, 1.0-inch-diameter solid slug. A pressure transducer and data logger were used to measure and record water levels during each slug test.
The falling-head test measured the rate at which water levels returned to static conditions after the introduction of the solid PVC slug; whereas, the rising-head test measured the recovery of water levels to static conditions after the slug was removed. Efforts were made to avoid splashing effects during the introduction of the slug. The tests were terminated after water levels recovered to within 95 percent of the pre-test static levels. Only rising-head tests were evaluated for hydraulic conductivity when the static water level was below the top of the well screen, as recommended by Butler (1998).

The slug-test data were analyzed by using the Bouwer and Rice (1976) solution, which accounts for the effects of partial penetration and changing aquifer thickness (water-table conditions). A basic assumption of this analytical method is that the aquifer is representative of a porous medium and is considered isotropic, having no directional variation in hydraulic properties within the zone being tested. Additional assumptions are that the effects of elastic storage can be neglected and the position of the water table does not change during the slug test (Butler, 1998). Spreadsheets developed by Halford and Kuniansky (2002) were used for analysis of the slug-test data. Multiple slug tests were performed in all shallow wells at each aquifer-test site. The results of the slug tests from individual wells at each test site were averaged to derive an estimate of hydraulic conductivity for the surficial aquifer at the site.

\section{Data Analysis}

Water-level data were recorded in multiple wells during each aquifer test. Drawdown data calculated for shallow wells at each test site were analyzed with aquifer-test analytical software. The surficial aquifer at each site was unconfined. Initial analyses were conducted using AQTESOLVTM software (HydroSOLVE, Inc., 2003) and applying the Neuman (1974) solution. Further analyses were then conducted using WTAQ software (Barlow and Moench, 1999) and applying the Moench (1997) analytical solution.

The Neuman (1974) solution is based on the following assumptions: (1) the aquifer has infinite areal extent; (2) the aquifer is homogeneous and has uniform thickness; (3) the aquifer is unconfined; (4) the potentiometric surface initially is horizontal; (5) the flow is unsteady; (6) the pumping well can penetrate, fully or partially, the saturated thickness of the aquifer; (7) the aquifer is pumped at a constant rate; and (8) the diameter of the pumping well is very small, allowing for storage inside the pumping well to be neglected. Assumptions of the Moench (1997) analytical solution are similar to Neuman (1974) as follows: (1) the aquifer is homogeneous, infinite in lateral extent, horizontal, and of uniform thickness; (2) the aquifer can be anisotropic provided the principal directions of the hydraulic conductivity tensor are parallel to the coordinate axes; (3) vertical flow across the lower boundary of the aquifer is negligible; (4) a well discharges at a constant rate from a specified zone below an initially 
horizontal water table; (5) the change in saturated thickness of the aquifer caused by pumping is small compared with the initial saturated thickness; (6) the porous medium and fluid are slightly compressible and have constant physical properties; and (7) the initial hydraulic head is the same everywhere. Although required by the theoretical solutions, one or more of these assumptions likely were not met at each of the sites tested during this investigation.

Data collected from multiple observation wells during each aquifer test were plotted collectively on the same graph and visually fitted to analytical curves based on the Neuman (1974) solution using AQTESOLVTM software (HydroSOLVE, Inc., 2003) and the Moench (1997) solution using the WTAQ software (Barlow and Moench, 1999). Estimates of transmissivity were derived using both software packages, and estimates of specific yield were derived from the Neuman (1974) solution. Estimates of hydraulic conductivity were not derived from aquifer test data because of the large change in saturated thickness ( 25 to 56 percent) observed during the aquifer tests.

Estimates of transmissivity were derived using drawdown data collected from at least three shallow observation wells at each aquifer-test site. Analysis of drawdown data from the pumping well at each site produced significantly lower transmissivity values than analysis of data from the observation wells. As a result, drawdown data from the pumping well at each test site were not used to determine aquifer properties. Drawdown data from observation wells installed within about $5 \mathrm{ft}$ of the pumping well were corrected using an adjustment for saturated thickness (Jacob, 1944). In some instances, however, drawdown from observation wells within $5 \mathrm{ft}$ remained excessive, even after the saturated thickness correction, and were not included in the analyses.

No corrections or adjustments were made to aquifer-test data based on water levels measured in nearby background wells. Likewise, no corrections were made to aquifer-test data as a result of water levels measured in the deep observation well at each site. Water-level and barometric-pressure data were not collected prior to the aquifer tests. Barometric pressure was monitored during each aquifer test, and no effects on water levels were observed. In general, barometric efficiency commonly is negligible for unconfined aquifers (Walton, 1996).

Estimates of the ratio of vertical to horizontal hydraulic conductivity $\left(\mathrm{K}_{\mathrm{z}} / \mathrm{K}_{\mathrm{r}}\right)$ and specific yield $\left(\mathrm{S}_{\mathrm{y}}\right)$ were obtained by applying the Neuman (1974) solution to intermediate and late-time drawdown data. The early-time data from most of the aquifer tests did not fit well with the Neuman (1974) solution. Therefore, estimates of specific storage $\left(\mathrm{S}_{\mathrm{s}}\right)$ derived by using this solution likely were in error. Additionally, the analysis of drawdown data collected from observation wells placed at different radial distances from the pumping well did not correlate well using the Neuman (1974) solution.

Estimates of aquifer hydraulic properties derived from the Neuman (1974) analytical solution $\left(\mathrm{K}_{\mathrm{z}} / \mathrm{K}_{\mathrm{r}}\right.$ and $\left.\mathrm{S}_{\mathrm{y}}\right)$ were then used for input into initial WTAQ (Barlow and Moench, 1999) program runs. The WTAQ (1999) program incorporates wellbore storage in the pumped well and delayed drawdown response at an observation well using the Moench (1997) analytical solution. The program initially was run in dimensional mode using initial values of $\mathrm{S}_{\mathrm{s}}$ and $\mathrm{S}_{\mathrm{y}}$ from the Neuman (1974) solution and by calculating $\mathrm{K}_{\mathrm{z}}$ from the Neuman (1974) $\mathrm{K}_{\mathrm{z}} / \mathrm{K}_{\mathrm{r}}$ ratio and slug test $\left(\mathrm{K}_{\mathrm{r}}\right)$ values. Instantaneous drawdown at the water table was assumed. Values of $\mathrm{S}_{\mathrm{s}}$ and $\mathrm{K}_{\mathrm{z}}$ were adjusted until dimensional fits were obtained for the observation well dataset. The WTAQ (Barlow and Moench, 1999) dimensional mode solution generally fit the early-time drawdown data much better than the Neuman (1974) solution. The observation well response delay (Moench, 1997) was applied, resulting in a steepening of the early-time drawdown data, and a narrowing of the time differences between the response of the nearest and farthest observation wells (E.P. Weeks, U.S. Geological Survey, written commun., 2005).

The final step in the WTAQ (1999) program runs focused on the generation of type curves for a more detailed fit to observation-well drawdown data. For type-curve generation, dimensional mode results for $\mathrm{K}_{\mathrm{z}} / \mathrm{K}_{\mathrm{r}}$ and $\mathrm{S}_{\mathrm{s}} / \mathrm{S}_{\mathrm{y}}(\operatorname{sigma}(\sigma))$ were used. Additionally, factors for wellbore storage in the pumping well and response delay in the observation wells were incorporated in the solution. These parameters were adjusted until reasonable fits to the observation-well data were obtained. Transmissivity was then calculated following procedures outlined in Barlow and Moench (1999). In general, analysis of the aquifer-test data using the WTAQ (1999) program produced a better fit for the early-time data (affected by wellbore storage) and for drawdown data collected from observation wells installed at different radial distances from the pumping well (delayed observation-well response; E.P. Weeks, U.S. Geological Survey, written commun., 2005) and, thus, provided a better estimate of transmissivity.

\section{Hydraulic Properties of the Surficial Aquifer in Selected Topographic Settings}

Hydraulic properties were determined for the surficial aquifer at five test sites in three selected topographic settings. One test site was located in an upland or hilltop setting (Triangle site). Two test sites were located on a hillside or slope setting (Barrett's Farm and Scuffleton), and two sites were located in a valley-flat or flood-plain setting (Ballards Crossroads and Farmville).

\section{Triangle Site (Upland or Hilltop)}

The Triangle site is located in Greene County, North Carolina (NC), in an upland area at the intersection of NC Highway 91 and Fire Tower Road, approximately 3 miles south of the town of Walstonburg (fig. 11). Wells at the 

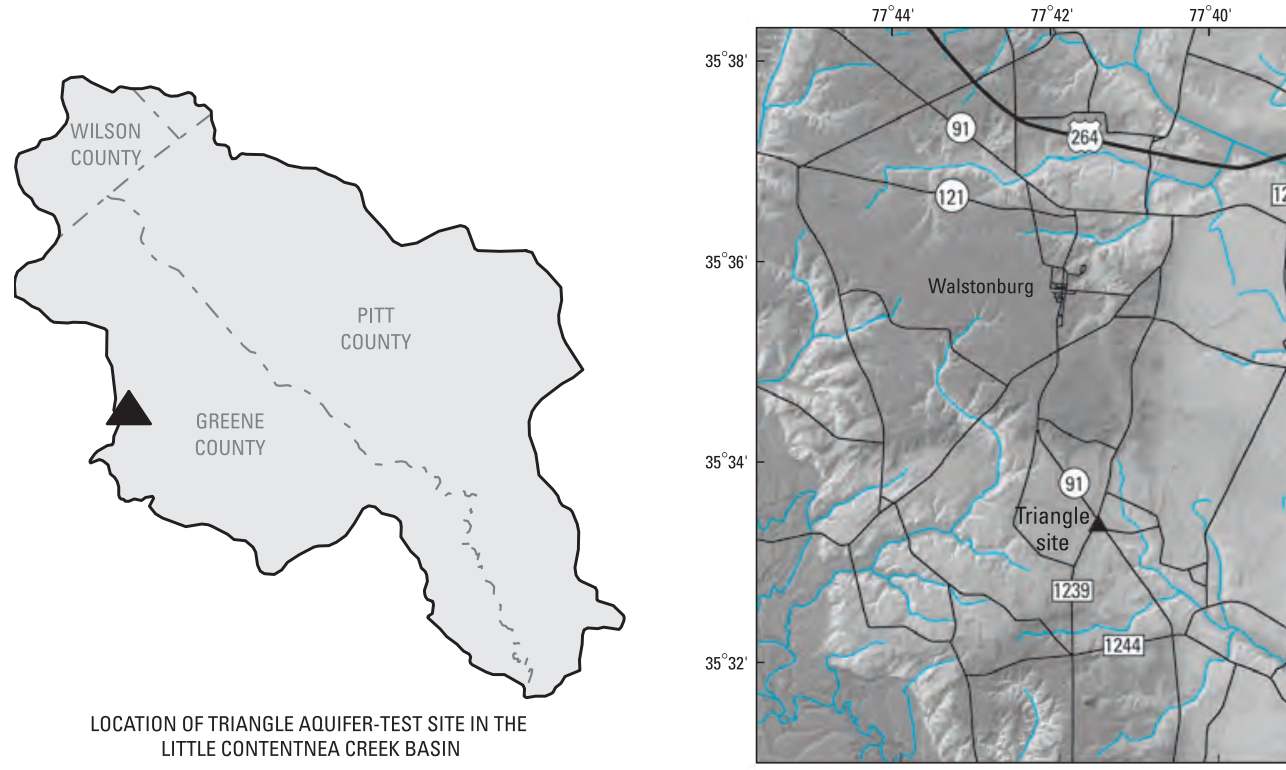
LITTLE CONTENTNEA CREEK BASIN

$$
\begin{aligned}
& \text { Base from digital files of: } \\
& \text { U.S. Department of Commerce, } \\
& \text { Bureau of Census, } 1990 \text { Precensus } \\
& \text { TIGER/Line Files-Political boundaries, } 1991 \\
& \text { 2001 LIDAR elevation data, North Carolina } \\
& \text { Floodplain Mapping Program }
\end{aligned}
$$

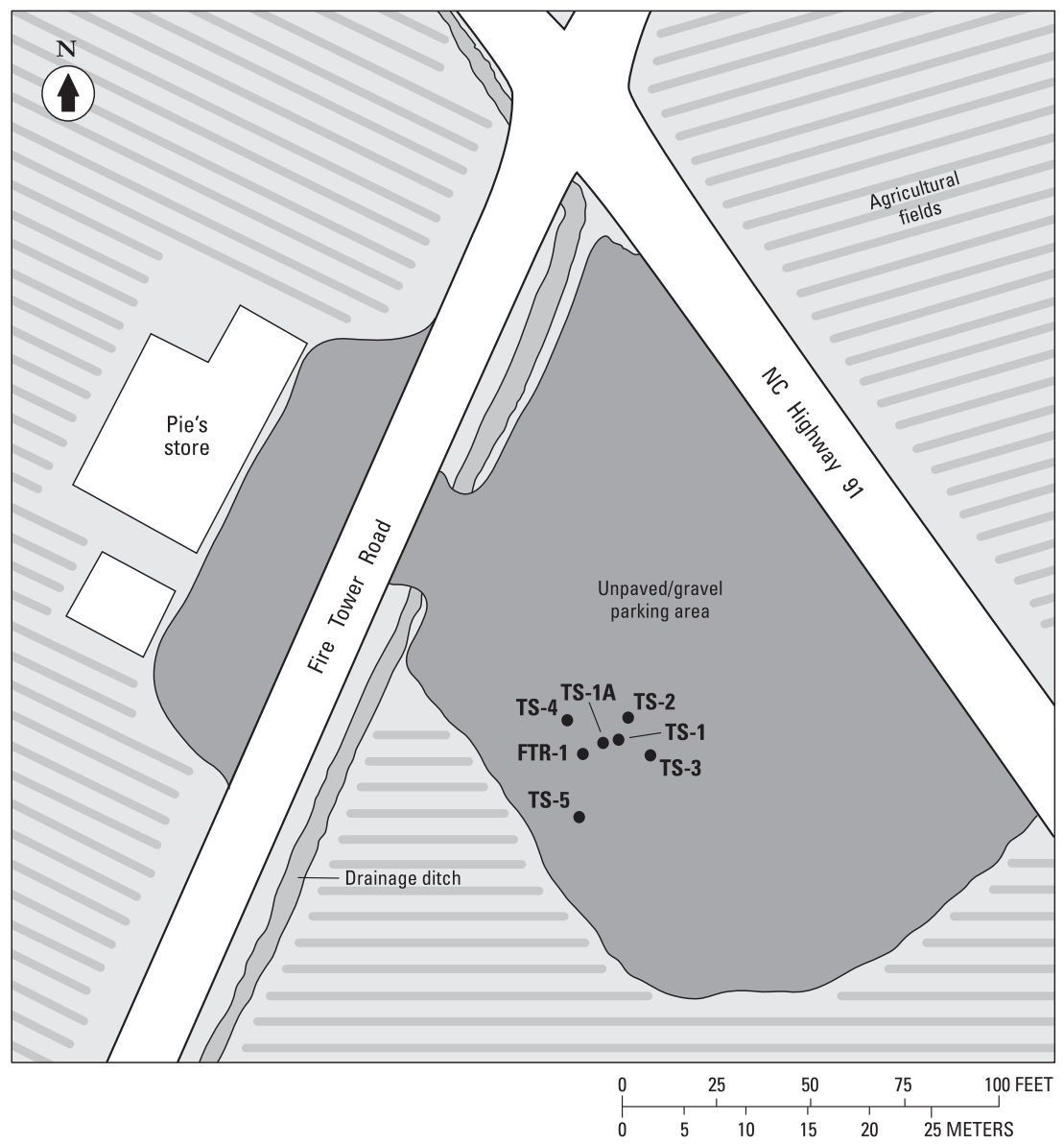

Figure 11. Locations of wells at the Triangle aquifer-test site in Greene County, North Carolina. 
Triangle site were drilled about $80 \mathrm{ft}$ west of NC Highway 91 on an unpaved parking lot that is partially covered with gravel (fig. 11). Cultivated fields occupy most of the surrounding area. During each aquifer test at the Triangle site, a few inches of water was present in the bottom of a roadside drainage ditch that runs parallel to Fire Tower Road (fig. 12). This ditch is about $70 \mathrm{ft}$ north and west of the test wells. Water levels in this ditch were measured throughout the duration of the first aquifer test conducted at the Triangle site. The water level in the ditch remained relatively stable and did not decline rapidly as a result of pumping during the course of the aquifer test. As a result, no substantial connection was considered to exist between the drainage ditch and the surficial aquifer, and water levels in the ditch were not monitored during subsequent aquifer tests conducted at the site.

\section{Test Design}

At the Triangle site, wire-line core samples and geophysical logs were collected to a depth of about $64 \mathrm{ft}$ below land surface. Geophysical well logs and field descriptions of core samples collected at the Triangle site are given in figure 13 . The core samples and well logs collected at the Triangle site indicate that the surficial aquifer is composed of multiple sediment layers. Each of these layers contains a mixture of sediment particles with grain sizes that range from clay to coarse sand. A well-defined confining layer composed of greenish-gray clay is about $22 \mathrm{ft}$ below land surface, marking the lower boundary of the surficial aquifer. Sediments high in clay content are present in the core samples collected from 22 to $48 \mathrm{ft}$ below land surface. Sandy sediments were observed in the core samples collected from 48 to $64 \mathrm{ft}$ below land surface.

After collecting core samples and geophysical logs, well screen and casing were installed in the core hole to monitor water levels in sediment layers beneath the surficial aquifer. This deeper well was screened from 49 to $64 \mathrm{ft}$ below land surface. All of the shallow wells at the Triangle site were drilled to a depth of about $24 \mathrm{ft}$ below land surface and were screened from approximately 9 to $24 \mathrm{ft}$ below land surface (table 1).

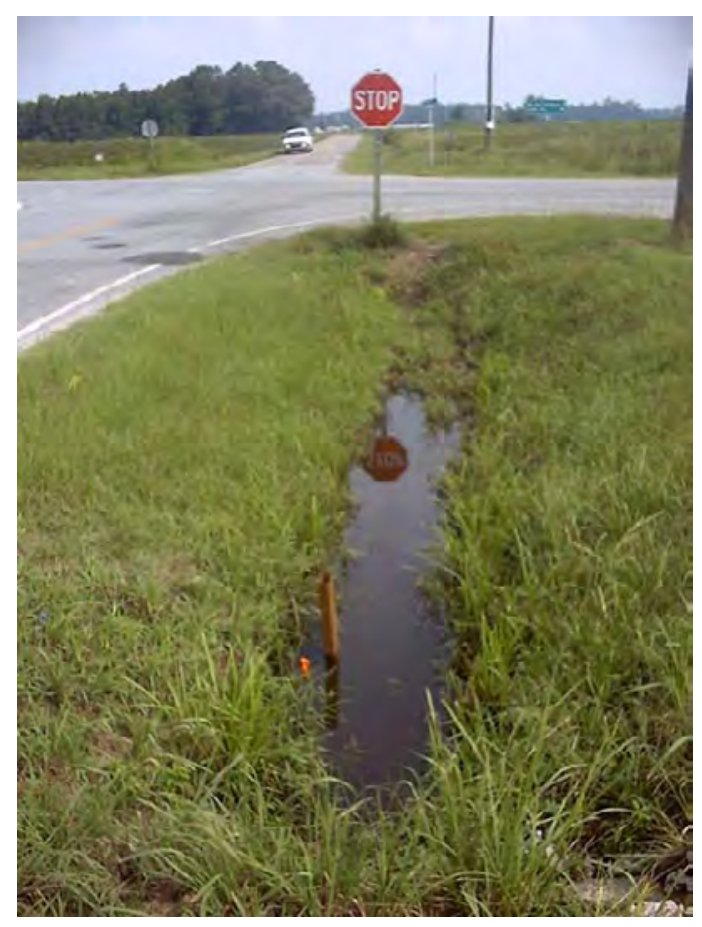

Figure 12. Water in roadside ditch about 70 feet north and west of test wells at the Triangle aquifertest site (photograph by D.G. Smith, U.S. Geological Survey, 2002). 

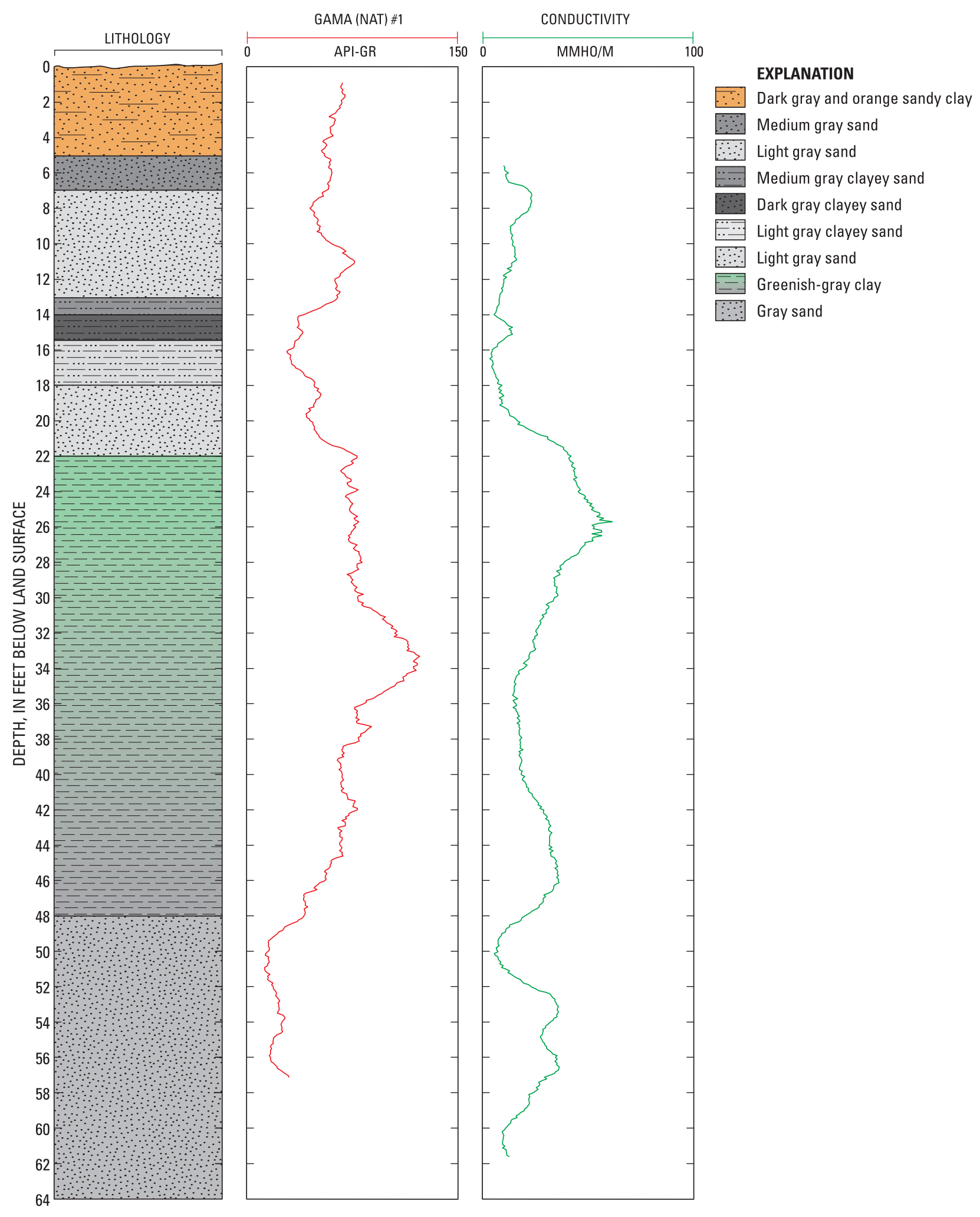

Figure 13. Field description of subsurface sediment layers and geophysical logs collected at the Triangle aquifer-test site in the Little Contentnea Creek basin. 


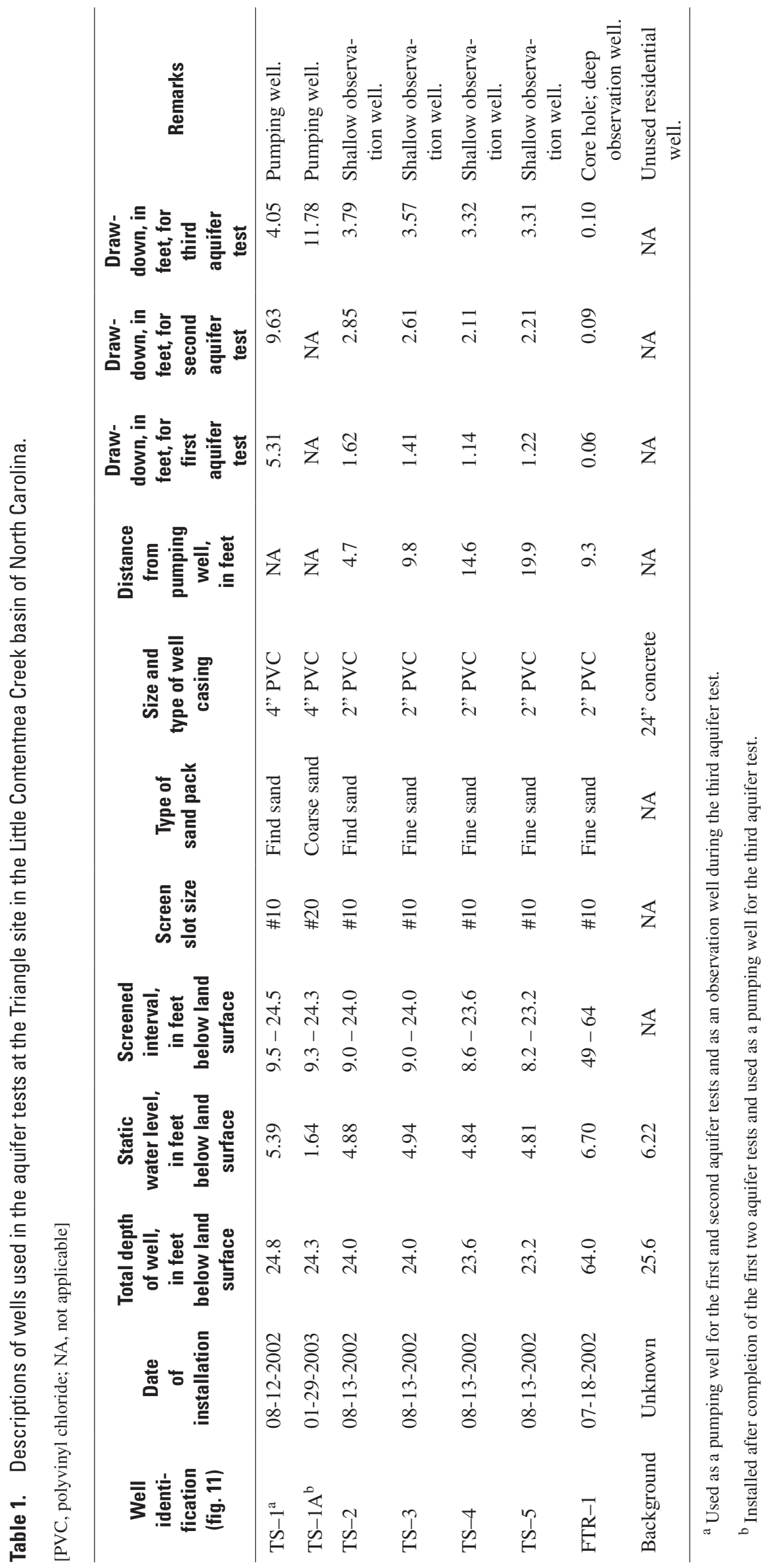


An abandoned shallow well, located about 0.6 mile east of the Triangle test site (fig. 14), was used to record background water levels in the surficial aquifer throughout the duration of each aquifer test at this site. The total depth of this well was measured at $25.6 \mathrm{ft}$ below land surface. This well originally was constructed as a 24-inch-diameter bored residential well.

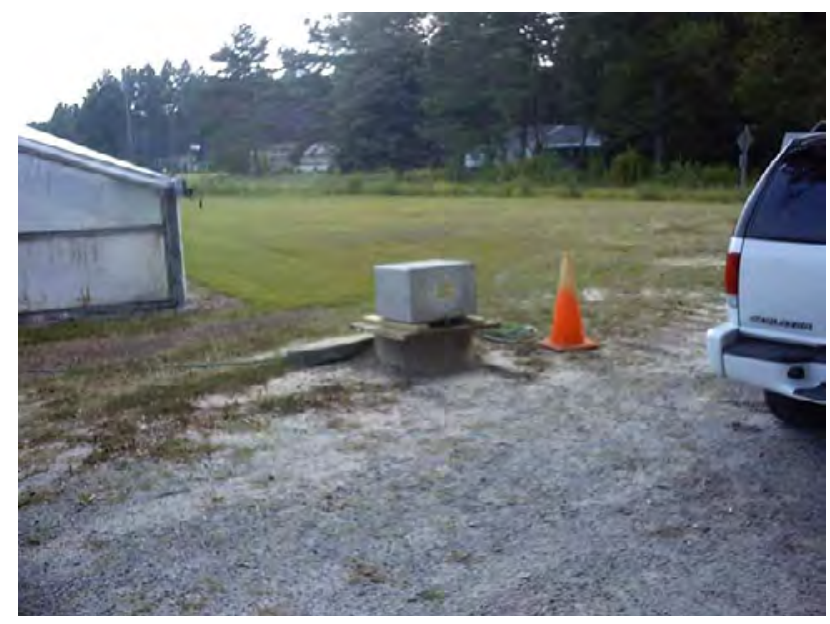

Figure 14. Instrument shelter atop concrete casing of abandoned residential well used for monitoring background water-level fluctuations during aquifer tests at the Triangle site (photograph by D.G. Smith, U.S. Geological Survey, 2002).

The Triangle site was the first site to be tested during this investigation. Three different aquifer tests were conducted independently at the Triangle site using successively increased pumping rates, different pumping wells, and different test durations. The first two tests at the site were conducted using well TS-1 as the pumping well (fig. 15A), constructed with a \#10-slot screen and fine sand pack (table 1). The third test was conducted using a newly installed well (TS-1A) as the pumping well (fig. 15B). Well TS-1A was installed to the same depth as well TS- 1 but was constructed with a \#20-slot screen and coarse sand pack (table 1). The varied durations of the three aquifer tests conducted at the Triangle site were 42,72 , and 24 hours, respectively. The pumping rates used to complete these three tests were 1.8, 3.0, and 5.0 $\mathrm{gal} / \mathrm{min}$, respectively. During each aquifer test at the Triangle site, water that was pumped from the surficial aquifer was discharged about 450 to $750 \mathrm{ft}$ south of the test site into a drainage ditch that lies parallel to NC Highway 91.

The first aquifer test at the Triangle site was scheduled to be conducted for a period of 72 hours but was shut down after 42 hours of pumping. This test was stopped earlier than planned because the pumping rate was lower than specified by preliminary testing and because the typical delayed-yield response was not observed in drawdown data. A second aquifer test was conducted at the Triangle site at the pumping rate of $3.0 \mathrm{gal} / \mathrm{min}$ for a period of 72 hours. The typical delayed-yield response also was not observed in the data collected during the second test. In order to maximize the stress applied to the surficial aquifer and increase drawdown in observation wells, a third test was conducted by pumping well TS-1A (with increased screen-slot size) for a period of 24 hours at the rate of $5.0 \mathrm{gal} / \mathrm{min}$. Although the length of the third test was shortened, the increased pumping rate produced greater drawdown. A typical delayed-yield response, however, was not observed in data collected during the third test at the Triangle site. Although the aquifer tests at the Triangle site were conducted using different wells, pumping rates, and test durations, the aquifer properties derived by using the Neuman (1974) and Moench (1997) solutions from these three different tests were essentially the same (table 2). Drawdown data collected from observation well TS-4 were not used in the aquifer-test analyses because of potential construction problems identified during later slug testing. 
A.

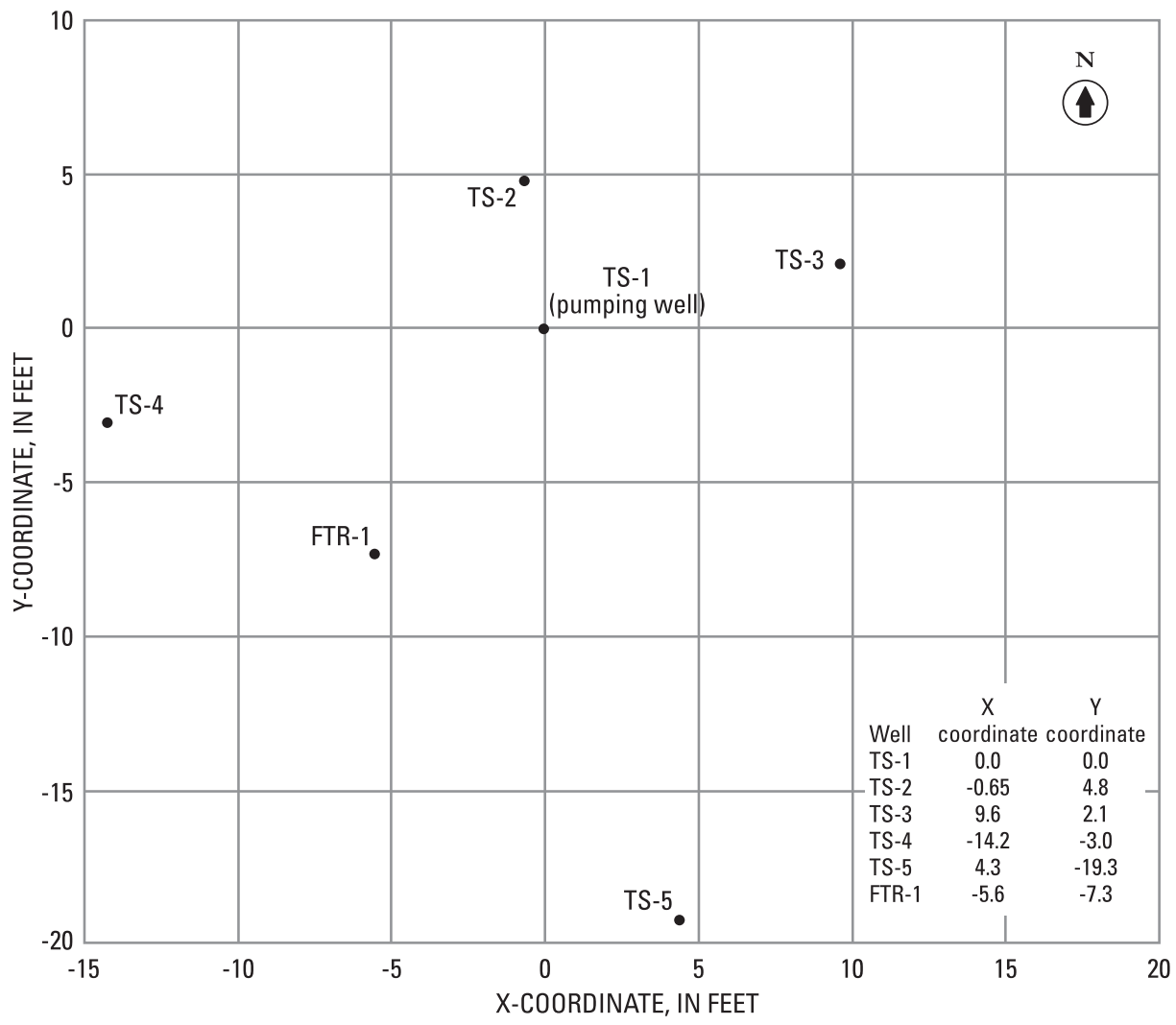

B.

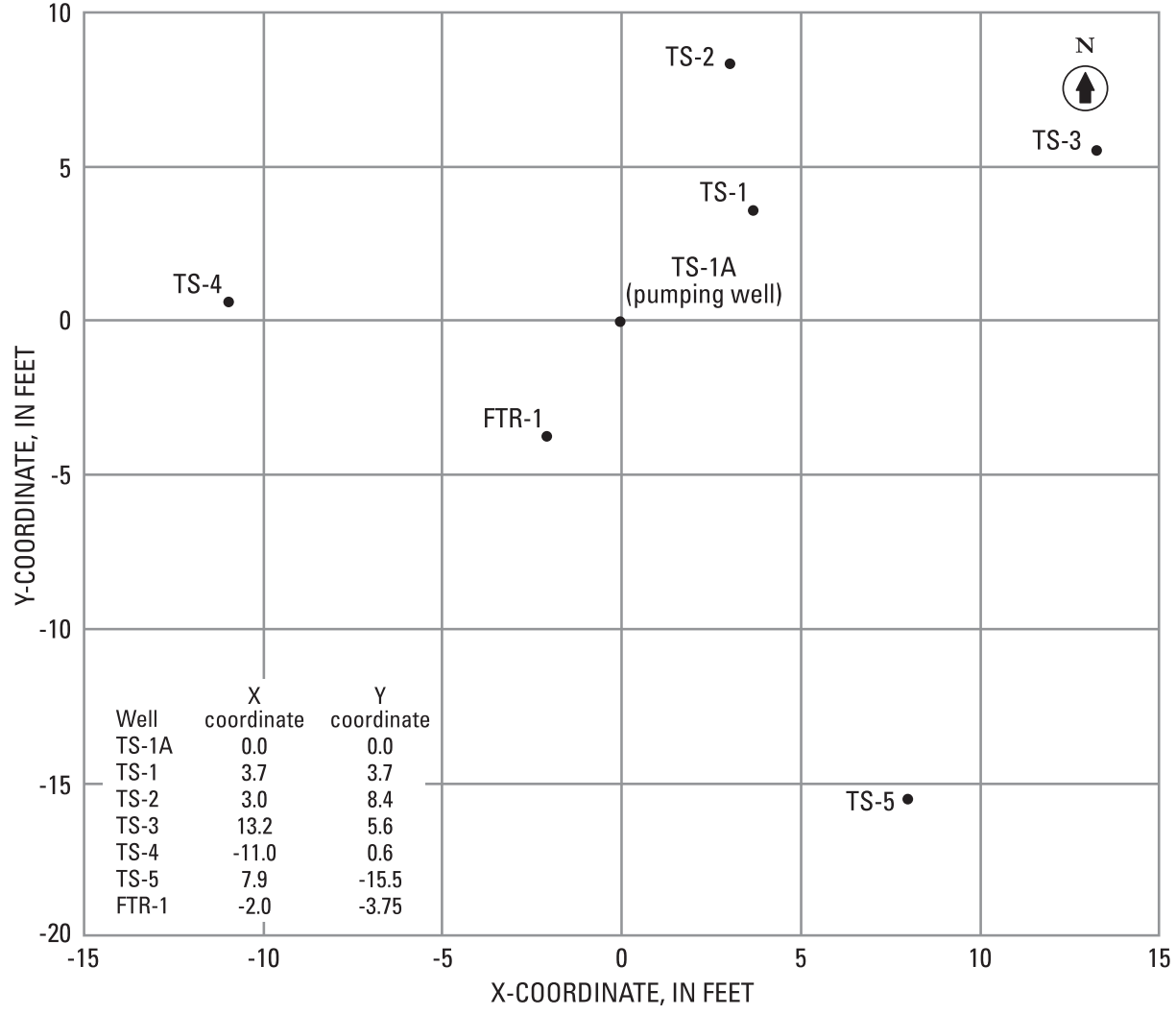

Figure 15. Cartesian coordinates for the pumping well and observation wells at the Triangle site for the (A) first and second, and (B) third aquifer tests. 
Table 2. Transmissivity, hydraulic conductivity, and specific yield estimates for aquifer tests conducted in the Little Contentnea Creek basin of North Carolina.

[All values were derived by using data from multiple shallow observation wells at each test site]

\begin{tabular}{|c|c|c|c|c|c|c|c|}
\hline \multirow{3}{*}{$\begin{array}{l}\text { Analytical } \\
\text { method }\end{array}$} & \multirow{2}{*}{\multicolumn{3}{|c|}{$\begin{array}{c}\text { Hilltop setting } \\
\text { Triangle site }\end{array}$}} & \multicolumn{2}{|c|}{ Hillside setting } & \multicolumn{2}{|c|}{$\begin{array}{c}\text { Valley bottom / flood-plain } \\
\text { setting }\end{array}$} \\
\hline & & & & \multirow{2}{*}{$\begin{array}{c}\text { Barrett's Farm } \\
\text { site }\end{array}$} & \multirow{2}{*}{$\begin{array}{c}\text { Scuffleton } \\
\text { site }\end{array}$} & \multirow{2}{*}{$\begin{array}{c}\text { Ballards } \\
\text { Crossroads } \\
\text { site }\end{array}$} & \multirow{2}{*}{$\begin{array}{l}\text { Farmville } \\
\text { site }\end{array}$} \\
\hline & Test 1 & Test 2 & Test 3 & & & & \\
\hline \multicolumn{8}{|c|}{ Transmissivity, in feet squared per day } \\
\hline $\begin{array}{l}\text { Neuman }(1974) \\
\text { solution }^{\mathrm{a}}\end{array}$ & 130 & 120 & 130 & 200 & 450 & 55 & 210 \\
\hline Moench (1997) & 160 & 150 & 170 & 200 & 500 & 89 & 310 \\
\hline \multicolumn{8}{|c|}{ Hydraulic conductivity, in feet per day } \\
\hline Slug tests ${ }^{b}$ & & 5.8 & & 4.1 & 3.3 & 4.6 & 21 \\
\hline \multicolumn{8}{|c|}{ Specific yield, unitless } \\
\hline $\begin{array}{l}\text { Neuman }(1974) \\
\text { solution }^{\mathrm{a}}\end{array}$ & 0.02 & 0.03 & 0.1 & 0.08 & 0.06 & 0.02 & 0.009 \\
\hline $\begin{array}{r}{ }^{\mathrm{a}} \text { Values are base } \\
{ }^{\mathrm{b}} \text { Average values } \\
\text { Kuniansky (2002). }\end{array}$ & $\begin{array}{l}\text { collectiv } \\
\text { ased on }\end{array}$ & $\begin{array}{l}\text { natching } \\
\text { of data } f\end{array}$ & ole shall & $\begin{array}{l}\text { rvation wells. } \\
\text { d shallow observ }\end{array}$ & wells using & d Rice (1976 & lford and \\
\hline
\end{tabular}

\section{Results of the First Aquifer Test, September 2002}

The first aquifer test at the Triangle site was conducted over a period of 42 hours September 17-19, 2002. During this test, water was pumped from well TS-1 (fig. 15A) at a rate of $1.8 \mathrm{gal} / \mathrm{min}$. Saturated thickness measured in the surficial aquifer at the beginning of this test was $19.4 \mathrm{ft}$. Water levels measured in the background well declined by $0.09 \mathrm{ft}$ during the test. No corrections were made to the drawdown data collected in the observation wells as a result of this trend. Water levels measured in the deep well, FTR-1, declined by $0.06 \mathrm{ft}$ during the aquifer test, similar to the declines observed in the shallow background well. No corrections were made to the drawdown data from the observation wells based on water-level changes measured in the deep well.
Drawdown values calculated for shallow observation wells TS-2, TS-3, and TS-5 (fig.15A) were fitted collectively to theoretical curves based on the Neuman (1974; fig. 16) and Moench (1997; fig. 17) solutions. Excluding the pumping well (TS-1) and well TS-4, transmissivity estimates of 130 and 160 feet squared per day $\left(\mathrm{ft}^{2} / \mathrm{d}\right)$ were calculated for the first Triangle site test using the Neuman (1974) and Moench (1997) solutions, respectively (table 2). The Neuman (1974) typecurve fit represented the intermediate to late-time drawdown data better (fig. 16) and, thus, was used to determine specific yield. The specific yield estimate calculated for the first Triangle site test was 2 percent from the Neuman (1974) solution, which is representative of clayey sediments (Walton, 1970). 


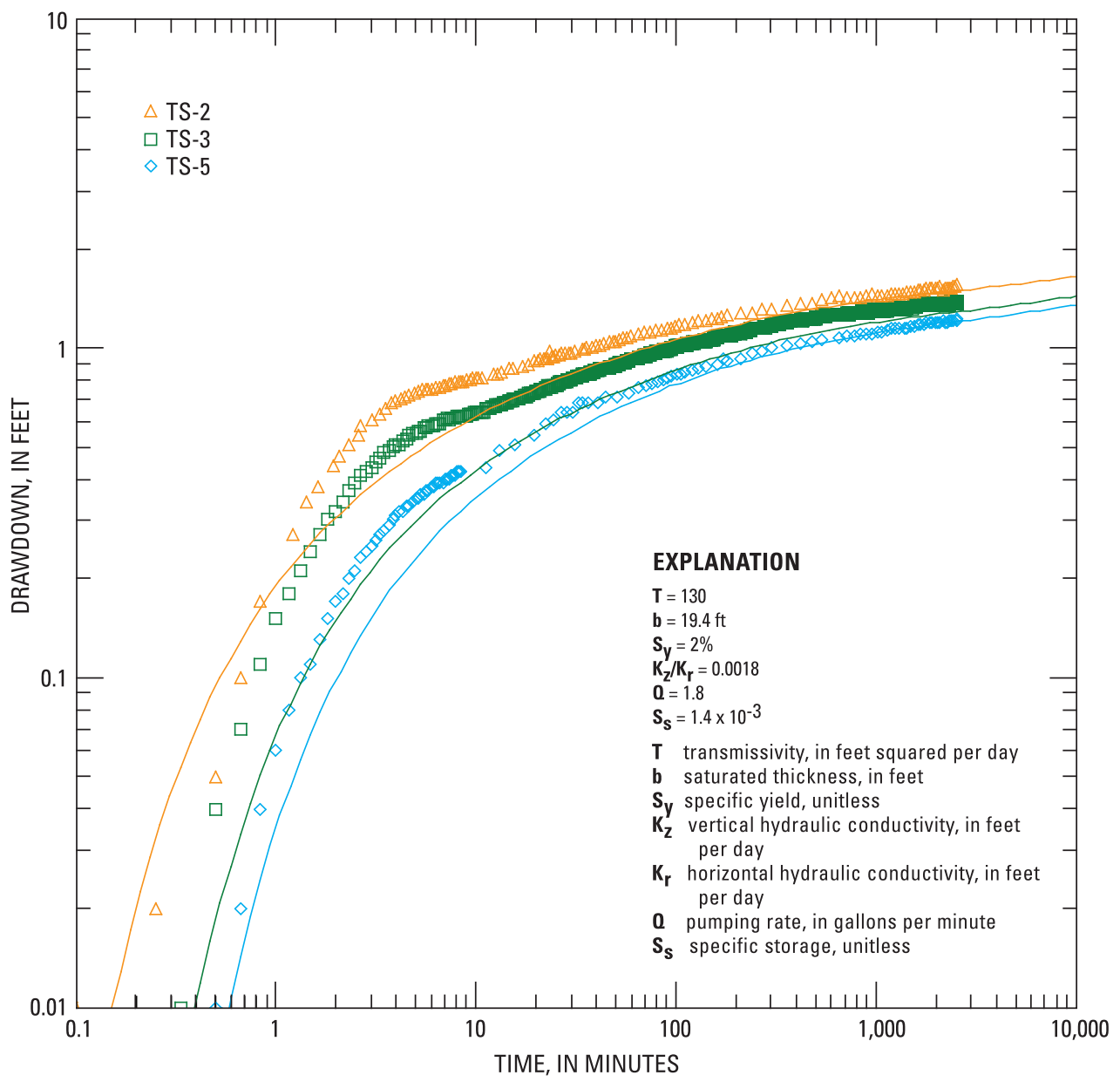

Figure 16. Drawdown data from observation wells during the first Triangle site aquifer test matched to the Neuman (1974) solution. 


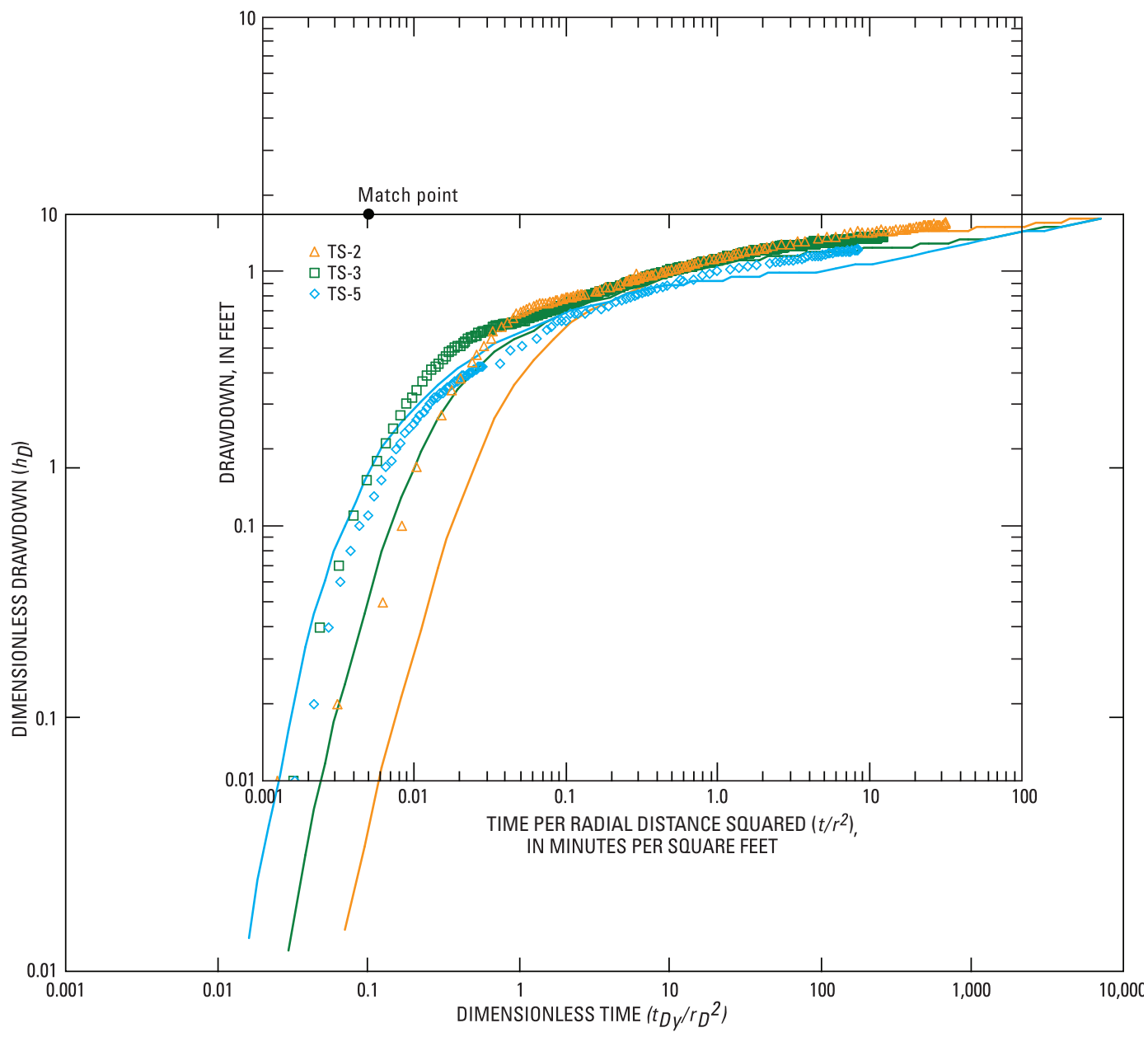

EXPLANATION

$\mathbf{T}=160$

b $=19.4 \mathrm{ft}$

$\mathrm{K}_{\mathbf{z}} / \mathrm{K}_{\mathbf{r}}=0.0017$

$\sigma\left(\mathrm{S}_{\mathrm{S}} / \mathrm{S}_{\mathrm{y}}\right)=0.007$

$\mathbf{0}=1.8$

WD $=160$

WDP $=450$

T transmissivity, in feet squared per day

b saturated thickness, in feet

$\mathbf{K}_{\mathbf{Z}}$ vertical hydraulic conductivity, in feet per day

$\mathbf{K}_{\mathbf{r}}$ horizontal hydraulic conductivity, in feet per day

$\boldsymbol{\sigma} \mathrm{S}_{\mathrm{S}} / \mathrm{S}_{\mathrm{y}}$, ratio of specific storage to specific yield, unitless

0 pumping rate, in gallons per minute

WD wellbore storage parameter

WDP delayed response factor

${ }^{t}{ }_{D y} / r_{D}{ }^{2}, h_{D} \quad$ (Barlow and Moench, 1999)

Figure 17. Moench (1997) type-curve overlay for the first Triangle site aquifer test. 


\section{Results of the Second Aquifer Test, October 2002}

The second aquifer test at the Triangle site was conducted over a period of 72 hours during October 8-11, 2002. During this test, water was pumped from well TS-1 (fig. 15A) at a rate of $3.0 \mathrm{gal} / \mathrm{min}$. Saturated thickness measured in the surficial aquifer at the beginning of the test was $18.6 \mathrm{ft}$. Water levels measured in the background well declined by $0.06 \mathrm{ft}$ during the test, and no corrections were made to the drawdown measured in the observation wells as a result of this trend. Water levels measured in the deep well (FTR-1) declined by $0.08 \mathrm{ft}$ during the aquifer test, similar to the declines observed in the shallow background well. No corrections were made to the drawdown data measured in the observation wells based on water-level changes measured in the deep well.
Drawdown data collected from shallow observation wells TS-2, TS-3, and TS-5 (fig. 15A) were fitted collectively to theoretical curves based on the Neuman (1974) and Moench (1997) solutions (figs. 18 and 19, respectively). Excluding the pumping well (TS-1) and well TS-4, transmissivity estimates of 120 and $150 \mathrm{ft}^{2} / \mathrm{d}$ were calculated for the second test at the Triangle site (table 2). As with the first Triangle aquifer test, intermediate and late-time drawdown data fit the Neuman (1974) solution (fig. 18). Specific yield for the second aquifer test was calculated at 3 percent from the Neuman (1974) solution, which is representative of clayey sediments (Walton, 1970).

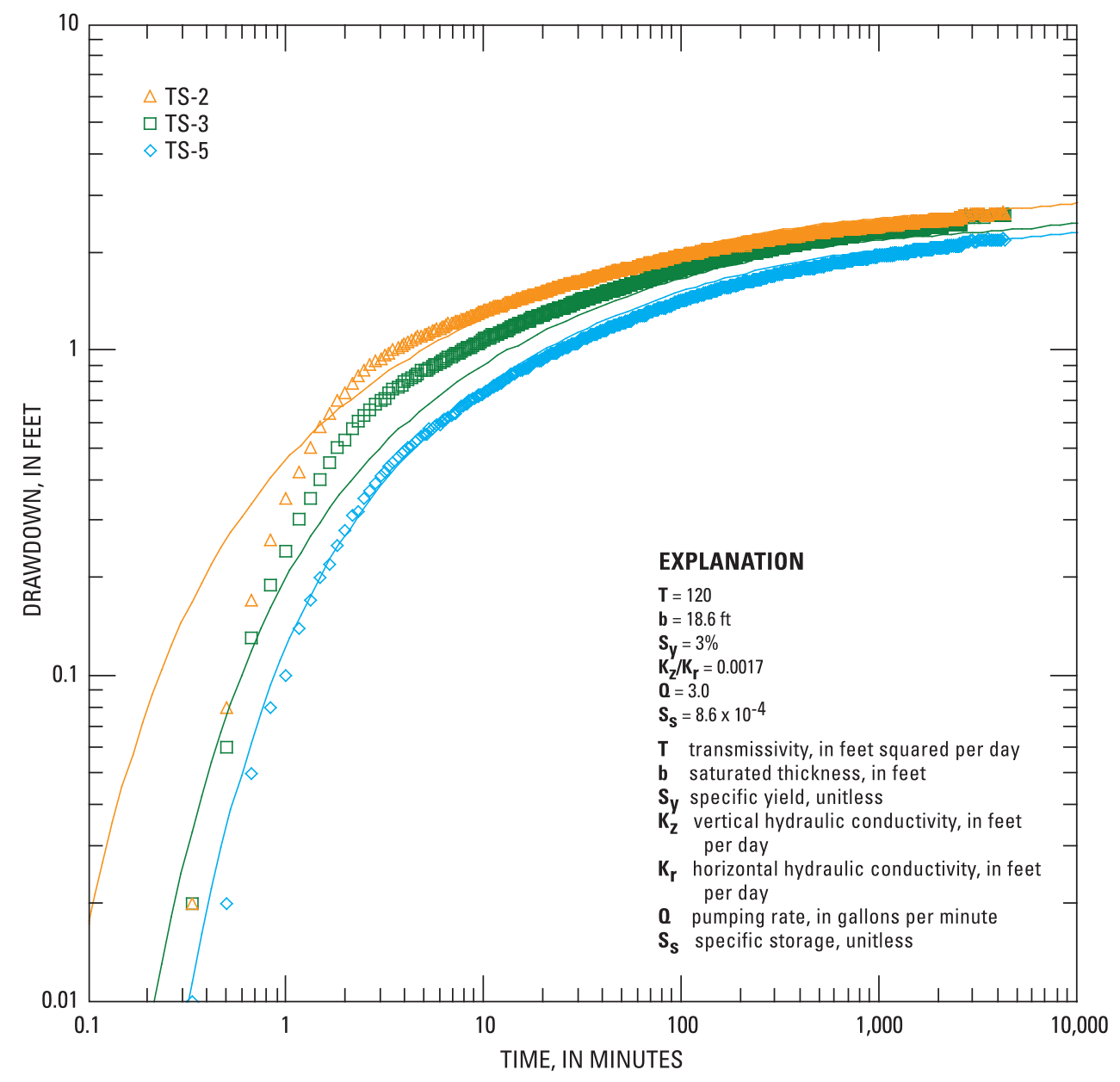

Figure 18. Drawdown data from observation wells during the second Triangle site aquifer test matched to the Neuman (1974) solution. 


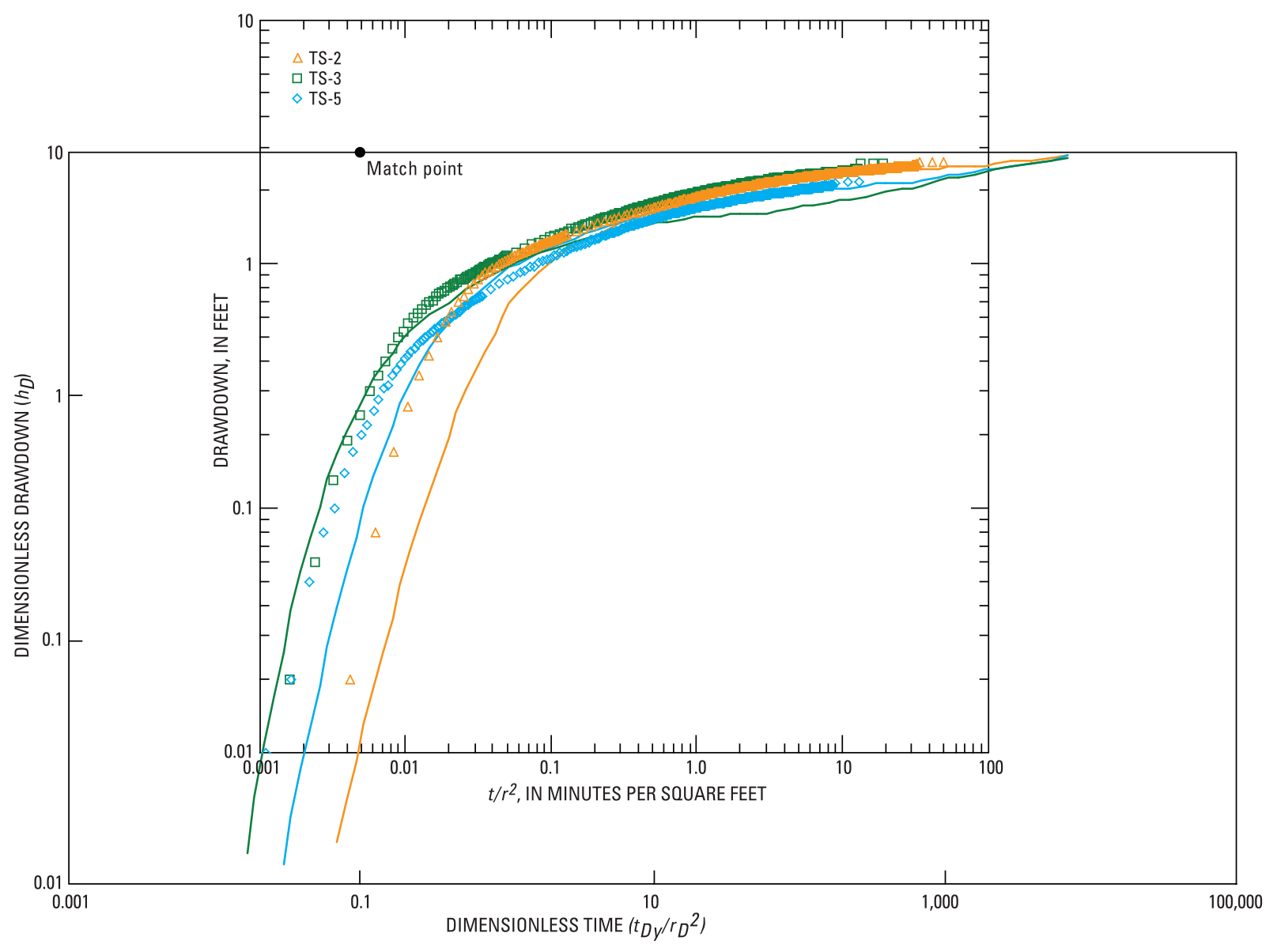

\footnotetext{
EXPLANATION

$T=150$

$\mathbf{b}=18.6 \mathrm{ft}$
$\mathbf{K}_{\mathbf{Z}} / \mathbf{K}_{\mathbf{r}}=0.0017$

$\sigma\left(S_{s} / S_{y}\right)=0.007$

WDP $=450$

T transmissivity, in feet squared per day

b saturated thickness, in feet

$\mathbf{K} \mathbf{z}$ vertical hydraulic conductivity, in feet per day

$\mathbf{K}_{\mathbf{r}}$ horizontal hydraulic conductivity, in feet per day

$\sigma S_{S} / S_{y}$, ratio of specific storage to specific yield, unitless

0 pumping rate, in gallons per minute

WD wellbore storage parameter

WDP delayed response factor

${ }^{t}{ }_{D y} / r_{D}{ }^{2}, h_{D} \quad$ (Barlow and Moench, 1999)
}

Figure 19. Moench (1997) type-curve overlay for the second Triangle site aquifer test. 


\section{Results of the Third Aquifer Test, March 2003}

The third test at the Triangle site was conducted March 27-28, 2003. For this test, well TS-1A (fig. 15B) was installed with a \#20-slot well screen and coarse sand pack placed in the annular space of the screened interval (table 1). This new well was designed to provide an increased pumping rate. As a result of funding constraints, the test was concluded after a 24-hour period. During this test, water was withdrawn at a rate of $5.0 \mathrm{gal} / \mathrm{min}$. The saturated thickness of the surficial aquifer at the beginning of the test was $22.7 \mathrm{ft}$. Water levels measured in the background well declined by $0.03 \mathrm{ft}$ during the test. Water levels measured in the deep well (FTR-1) declined by $0.10 \mathrm{ft}$ during the aquifer test, which was somewhat higher than the declines observed in the background well and may indicate slight leakage across the confining layer. No corrections were made to the drawdown data from the observation wells based on water-level changes measured in the background well or deep observation well.

As in the two previous tests at the Triangle site, drawdown values calculated for shallow observation wells during the third test were fitted collectively to theoretical curves based on the Neuman (1974) and Moench (1997) solutions (figs. 20 and 21, respectively). Excluding the pumping well (TS-1A), well TS-1 (located $5.0 \mathrm{ft}$ from the pumping well and used as an observation well during this test), and well TS-4, transmissivity estimates of 130 and $170 \mathrm{ft}^{2} / \mathrm{d}$ were calculated for the third test at the Triangle site (table 2). The Neuman (1974) solution fit the early-time drawdown slope fairly well (fig. 20). Specific yield for the third aquifer test was calculated to be 10 percent from the Neuman (1974) solution, which is representative of clayey sediments (Walton, 1970).

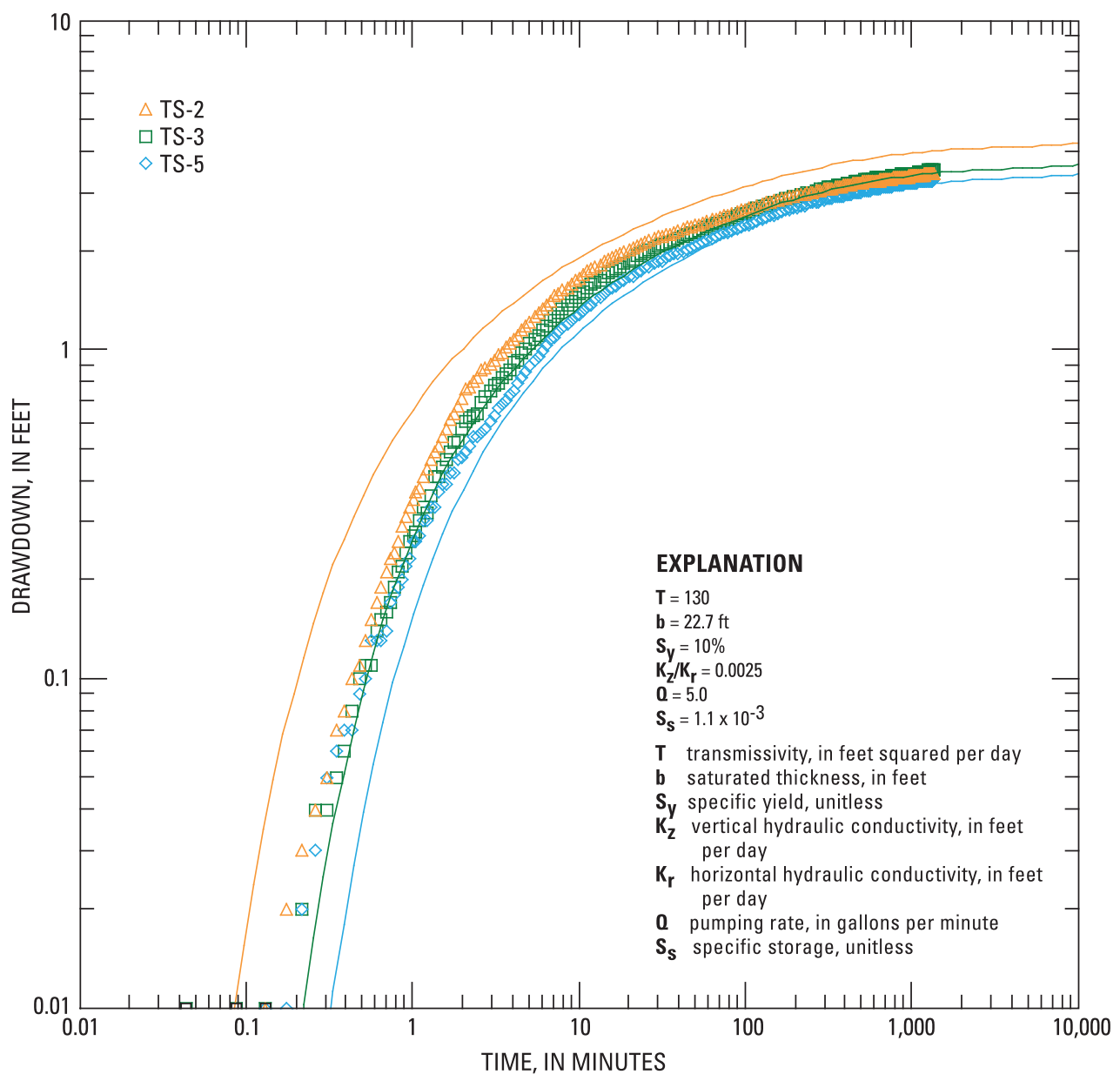

Figure 20. Drawdown data from observation wells during the third Triangle site aquifer test matched to the Neuman (1974) solution. 


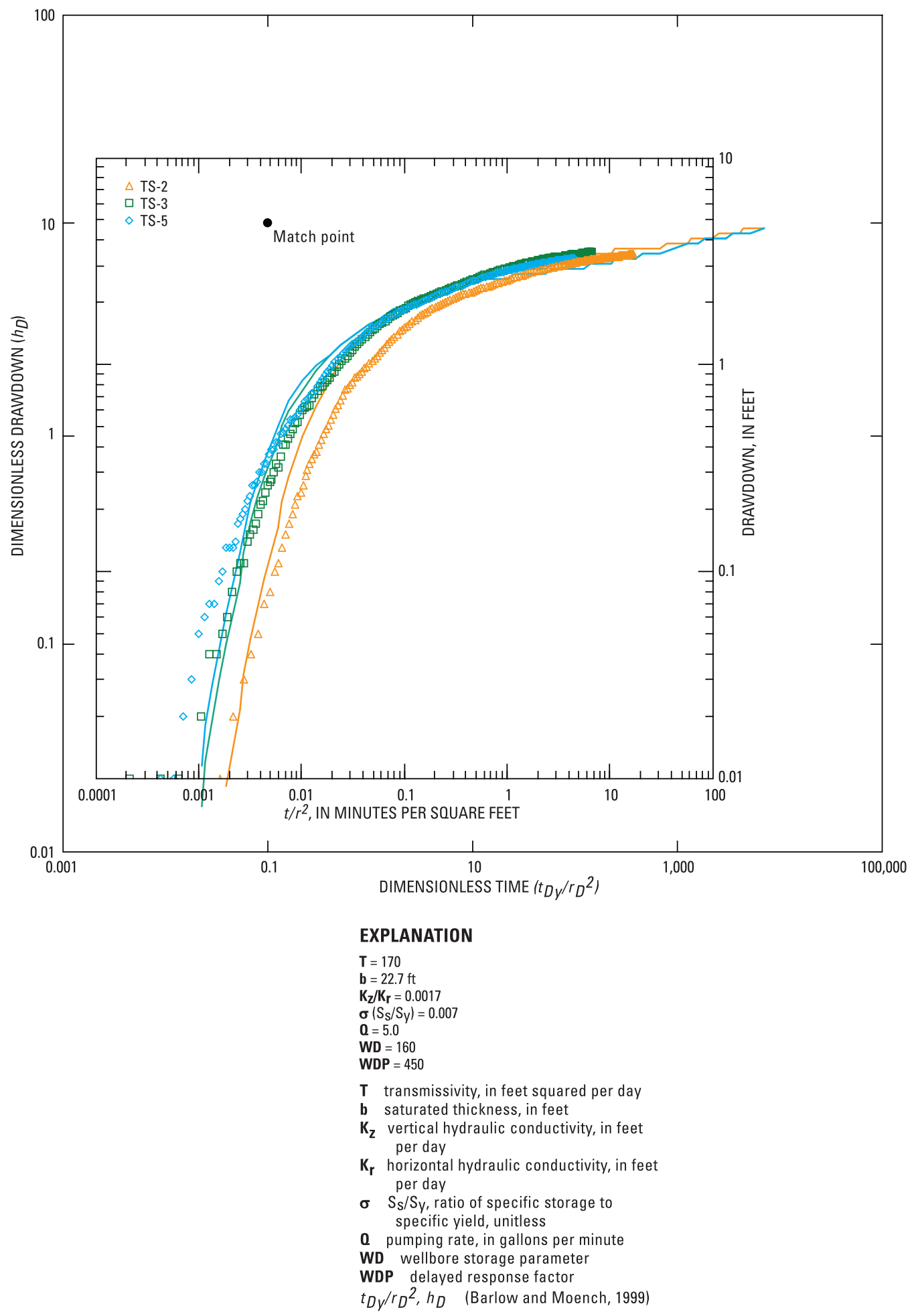

Figure 21. Moench (1997) type-curve overlay for the third Triangle site aquifer test. 


\section{Slug Tests}

In April 2004, slug tests were conducted on all shallow wells at the Triangle site. A solid slug was used to produce falling (slug-in) and rising (slug-out) head tests in each shallow well. Because of the substantial change in saturated thickness of about 25 to 51 percent during the Triangle aquifer tests, hydraulic conductivity is not reported from the Neuman (1974) and Moench (1997) solutions. Hydraulic conductivity estimates derived from application of the Bouwer and Rice (1976) analytical solution to the slug test data ranged from 3.0 to $10 \mathrm{ft} / \mathrm{d}$ and averaged $5.8 \mathrm{ft} / \mathrm{d}$ (table 2; appendix 1A). Slugtest results for one of the shallow observation wells (TS-4) at the Triangle site were unreasonably low. The hydraulic conductivity estimate for this well was not used to calculate the average hydraulic conductivity estimate for the site.

\section{Barrett's Farm Site (Hillside or Slope)}

The Barrett's Farm aquifer-test site is located on a tree farm about 3.5 miles east of the town of Saratoga, near the Greene County-Wilson County line (fig. 22). All wells at the Barrett's Farm site were installed on the side of a small hill in a cultivated field. The hill on which wells were installed slopes downward into a broad low-lying swampy area about $150 \mathrm{ft}$ south of the site (fig. 22). Standing water was present across much of this low-lying area during the aquifer test. This swampy area may have contributed water to the surficial aquifer during pumping, thereby producing less drawdown and higher transmissivity estimates than would have been determined otherwise. No provisions were made to monitor water levels in the swampy area during the aquifer test.

Wire-line core samples collected from areas within 2 miles of the Barrett's Farm site as part of the test-site selection process were markedly different from core samples collected at the selected test site. As a result of the local variability in the near-surface sediment layers, the surficial aquifer at the Barrett's Farm site is not considered to be of infinite areal extent. Likewise, some interconnection between the surficial aquifer and deeper aquifers may be possible at this site because of the discontinuity of sediment layers in the area. Determining the areal extent or defining the lateral boundaries of the surficial aquifer and confining layer at the Barrett's Farm site was beyond the scope of this investigation.

\section{Test Design}

At the Barrett's Farm site, core samples and geophysical logs were collected to a depth of about $80 \mathrm{ft}$ below land surface. Geophysical well logs and field descriptions of core samples collected at the Barrett's Farm site are given in figure 23. The core samples and well logs collected at the Barrett's Farm site indicate that the surficial aquifer is composed of multiple sediment layers. Each of these layers contains a mixture of sediments that is high in sand content and described as silty to medium sands. A well-defined confining layer composed of gray clay is about $24 \mathrm{ft}$ below land surface, marking the lower boundary of the surficial aquifer. Sediments high in clay content are present in the core samples collected from about 24 to $28 \mathrm{ft}$ below land surface. Sandy sediments are predominant in core samples collected from 28 to $34 \mathrm{ft}$ below land surface. Sediment layers from 34 to 72 feet below land surface are generally high in clay content. Gray sand and clayey sand are present in the core samples collected below $72 \mathrm{ft}$.

After collecting core samples and geophysical logs, well screen and casing were installed in the core hole to provide a means of monitoring water levels in sediments beneath the surficial aquifer. This deeper well was screened from 30 to $35 \mathrm{ft}$ below land surface. The pumping well and four shallow observation wells were drilled to a depth of about $24 \mathrm{ft}$ below land surface and were screened from approximately 9 to $24 \mathrm{ft}$ below land surface (table 3).

An abandoned shallow well, located about 0.8 mile northeast of the test site, was used to record background water levels in the surficial aquifer throughout the duration of the aquifer test. The total depth of the background well was measured at $30.9 \mathrm{ft}$ below land surface. This well originally was constructed as a 24 -inch-diameter bored residential well.

\section{Results}

The aquifer test at the Barrett's Farm site was conducted February 24-27, 2003, over a period of 72 hours. During this test, water was withdrawn from pumping well CBW-1 (fig. 24) at the rate of $7.0 \mathrm{gal} / \mathrm{min}$. Water pumped from the aquifer was discharged about $150 \mathrm{ft}$ south and downhill from the test wells to the nearby swampy area. Saturated thickness measured in the surficial aquifer at the beginning of this test was $19.7 \mathrm{ft}$. Water levels measured in the background well declined by about $0.20 \mathrm{ft}$ during the test. No corrections were made to the drawdown measured in the observation wells as a result of this trend. Water levels measured in the deep well, CBC-3, declined by $1.29 \mathrm{ft}$ during the test. This larger amount of drawdown in the deep well indicates that leakage may have occurred across the confining layer beneath the surficial aquifer. This amount of drawdown in the deep well also may indicate some degree of interconnection between the surficial aquifer and deeper sediment layers at this site as a result of local discontinuity of the confining layer, or it may indicate a poor seal above the screen in the annular space of 


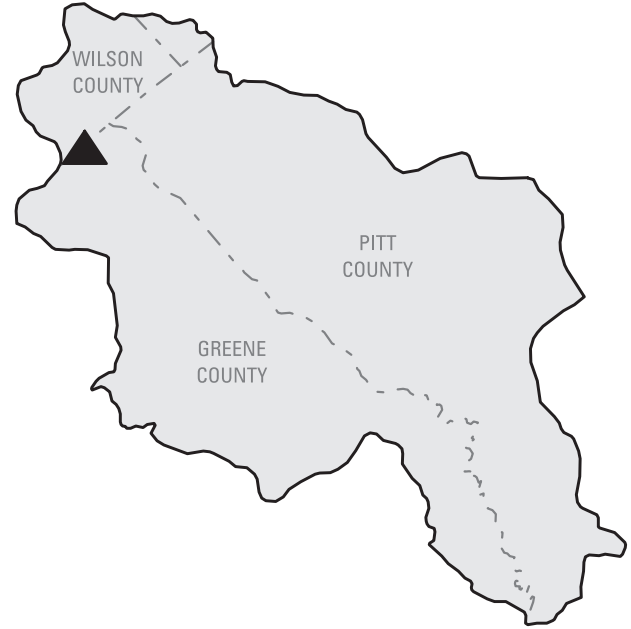

LOCATION OF BARRETT'S FARM AQUIFER-TEST SITE IN THE LITTLE CONTENTNEA CREEK BASIN
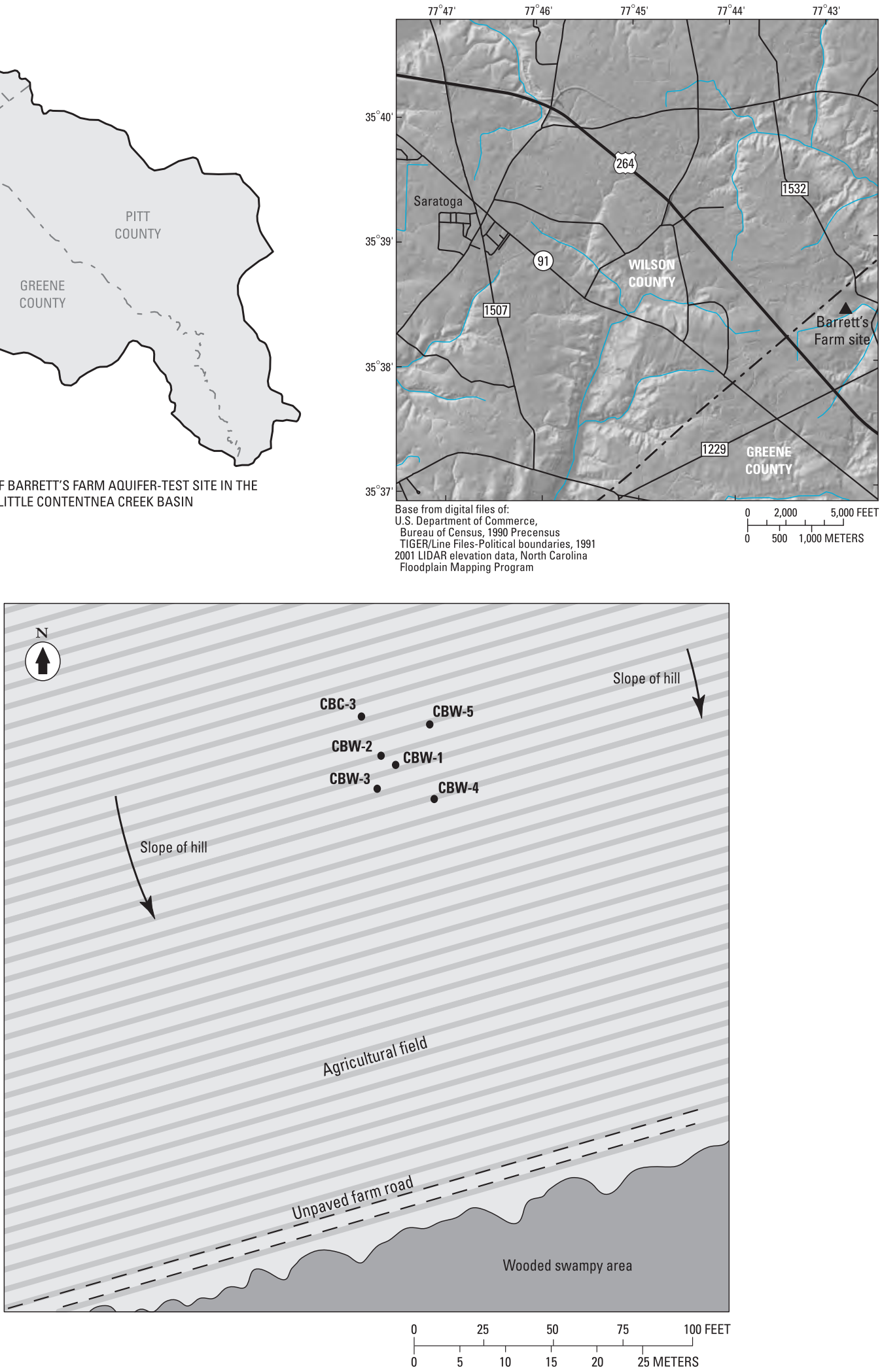

Figure 22. Locations of wells at the Barrett's Farm aquifer-test site in Greene County, North Carolina. 

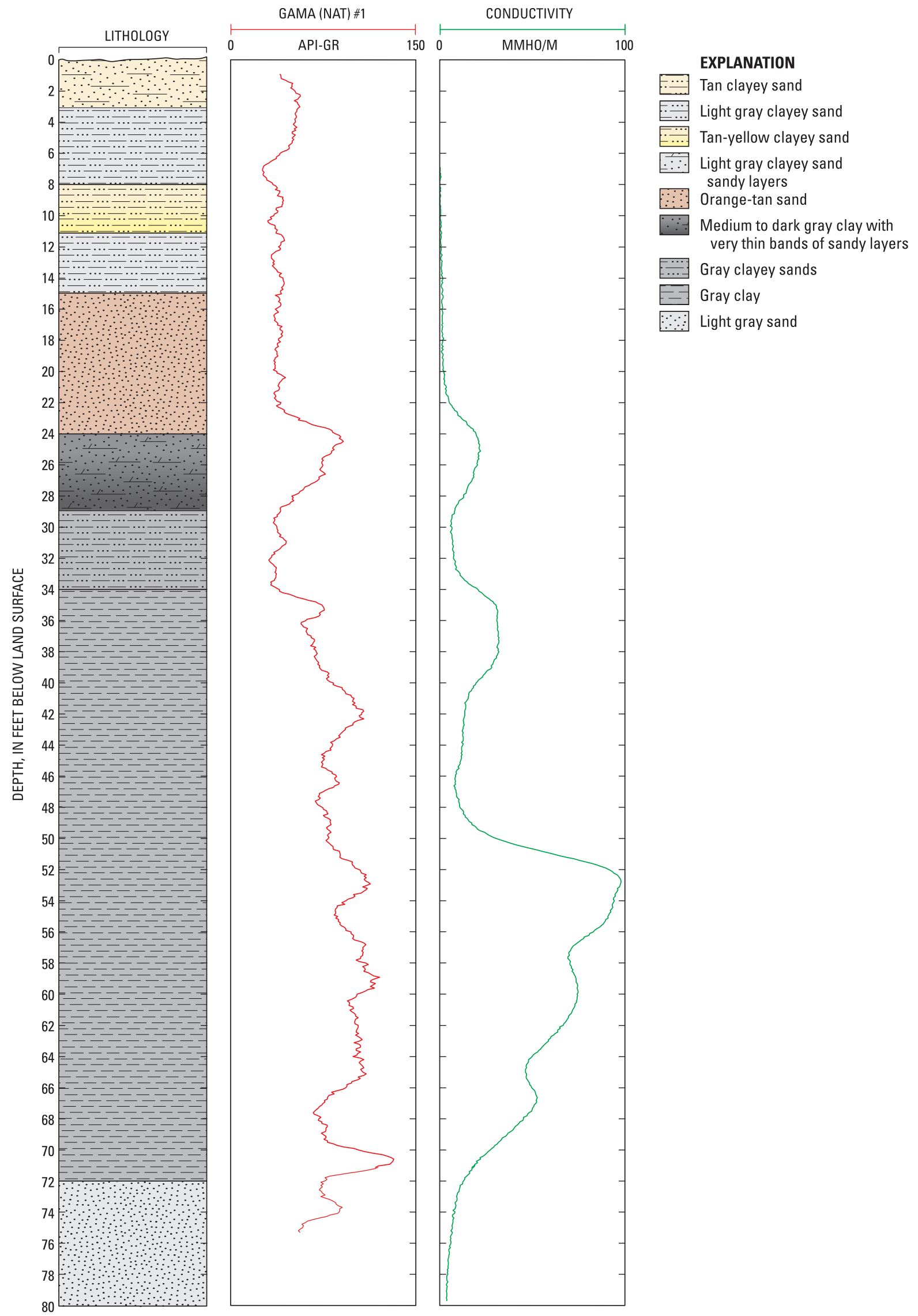

Figure 23. Field description of subsurface sediment layers and geophysical logs collected at the Barrett's Farm aquifertest site in the Little Contentnea Creek basin. 


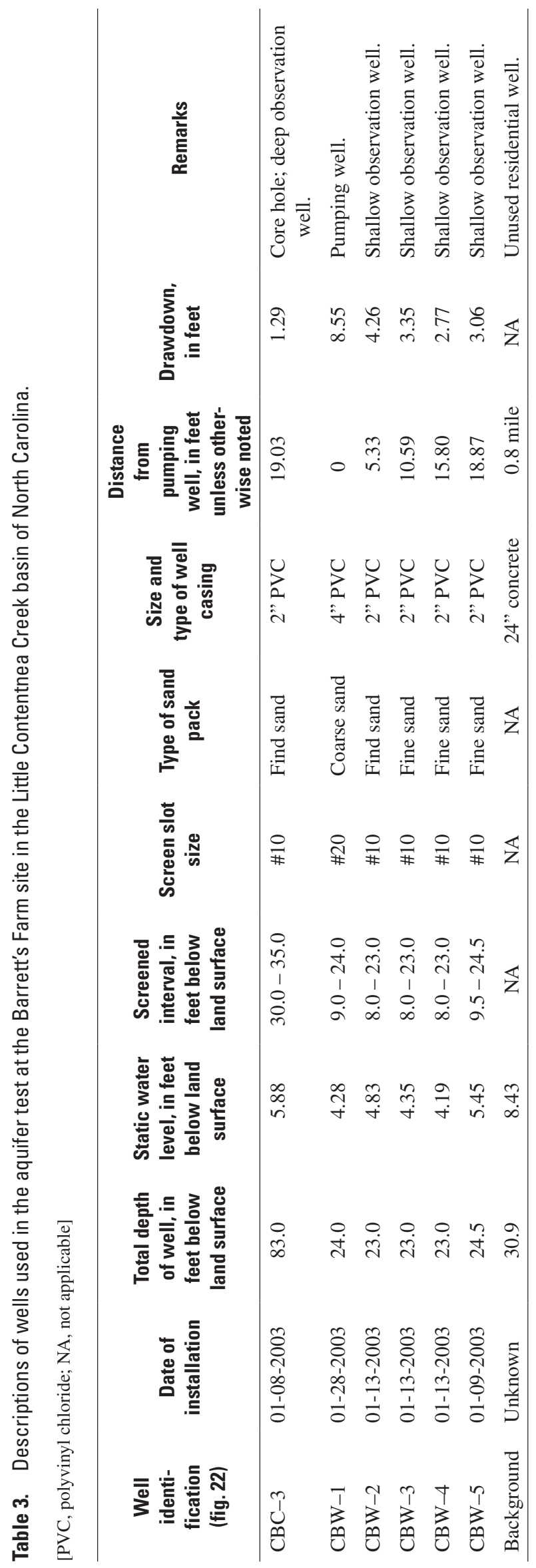




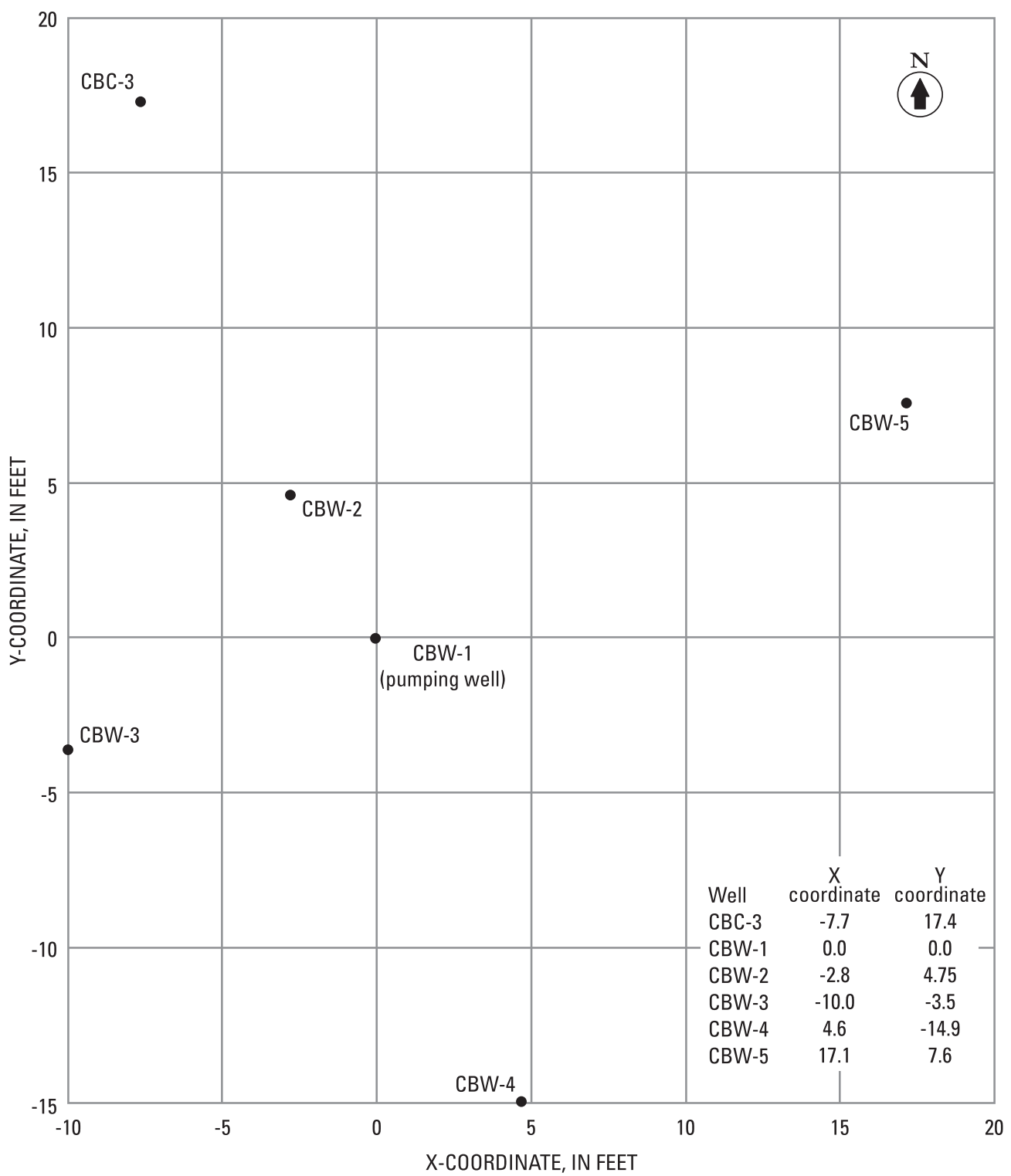

Figure 24. Cartesian coordinates for the pumping well and observation wells at the Barrett's Farm aquifer-test site. 
well $\mathrm{CBC}-3$. No adjustments were made to the drawdown data collected from the shallow wells based on water-level measurements made in the deep well.

Drawdown values calculated for shallow observation wells CBW-2, CBW-3, CBW-4, and CBW-5 (fig. 24) were fitted collectively to theoretical curves based on the Neuman (1974) and Moench (1997) solutions (figs. 25 and 26, respectively). Excluding the pumping well (CBW-1), a transmissivity estimate of $200 \mathrm{ft}^{2} / \mathrm{d}$ was calculated (using both analytical solutions) for the test site (table 2). The Neuman (1974) type-curve fit did not represent well the early-time drawdown data and the observation well response time differences (fig. 25), which indicated larger wellbore storage and observation well response delay as represented by the Moench (1997) type-curve fit (fig. 26). The Moench (1997) solution provided a better fit of early-time data and better represented drawdown responses at the closest (CBW-2) and farthest (CBW-5) observation wells (fig. 26). Data from this test had the highest values of wellbore storage and observation well response delay of the five test sites. Drawdown data from well CBW-3 did not fit the group Moench (1997) solution well, potentially because of local differences in aquifer properties. The specific yield was calculated to be 8 percent, which is representative of sandy sediments (Walton, 1970).

\section{Slug Tests Slug Tests}

In May 2004, slug tests were conducted on all shallow wells at the Barrett's Farm site. A solid slug was used to produce both falling (slug-in) and rising (slug-out) head tests in each shallow well. Because of the significant change of about 35 percent in saturated thickness during the aquifer test at this site, hydraulic conductivity is not reported from the Neuman (1974) and Moench (1997) solutions. Hydraulic conductivity values derived from application of the Bouwer and Rice (1976) analytical solution to the slug tests ranged from 2.9 to $6.1 \mathrm{ft} / \mathrm{d}$ and averaged $4.1 \mathrm{ft} / \mathrm{d}$ (table 2; appendix 1B).

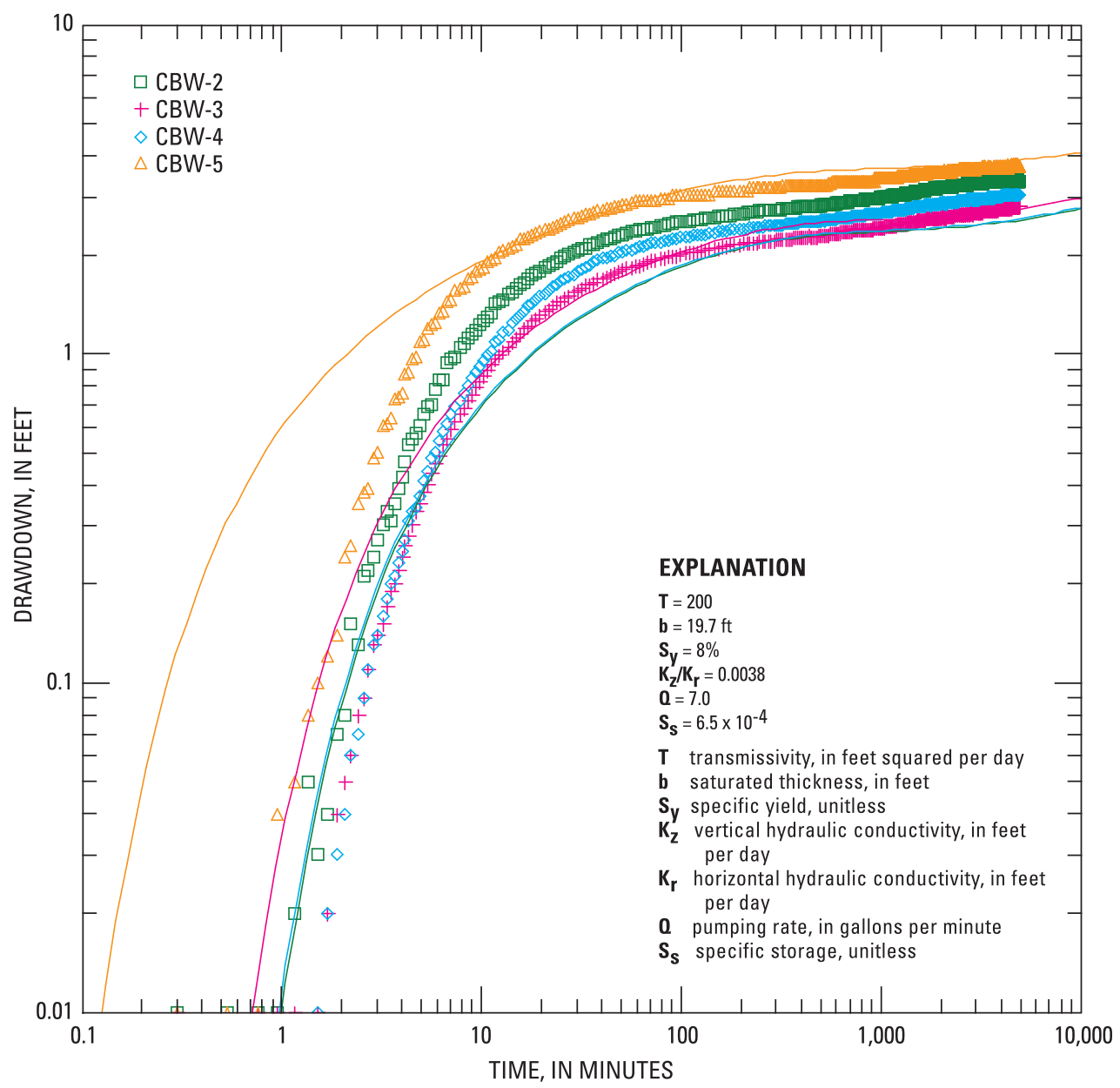

Figure 25. Drawdown data from observation wells during the Barrett's Farm site aquifer test matched to the Neuman (1974) solution. 


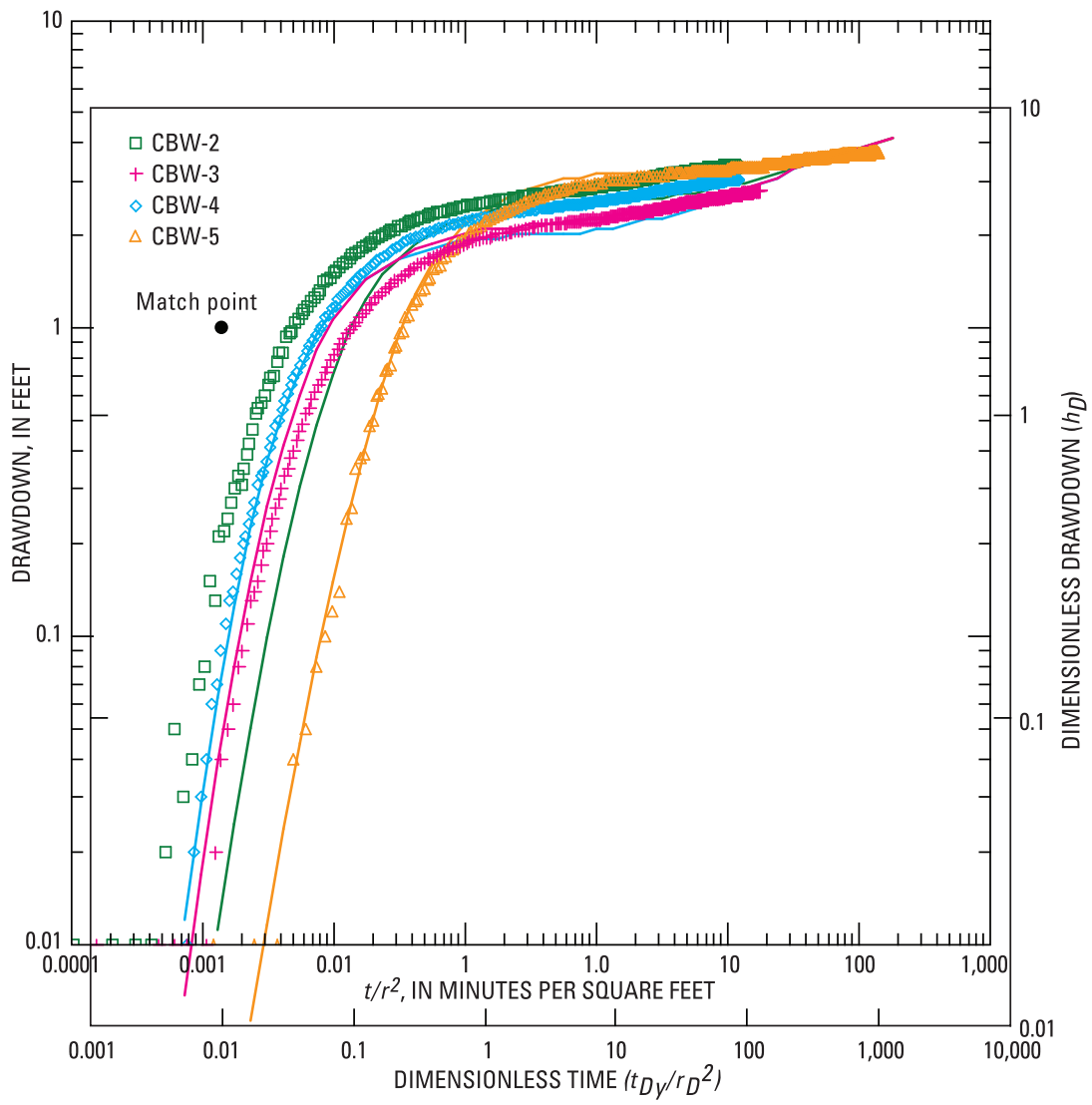

\section{EXPLANATION}

$$
\begin{aligned}
& T=200 \\
& \text { b }=19.7 \mathrm{ft} \\
& \mathrm{K}_{\mathbf{Z}} / \mathrm{K}_{\mathbf{r}}=0.013 \\
& \sigma\left(S_{S} / S_{y}\right)=0.00125 \\
& \text { WD }=390 \\
& \text { WDP }=970
\end{aligned}
$$

Figure 26. Moench (1997) type-curve overlay for the Barrett's Farm site aquifer test. 


\section{Scuffleton Site (Hillside or Slope)}

The Scuffleton test site is located in Pitt County on a hillside about 1.3 miles southeast of the community of Scuffleton and 3 miles southwest of the town of Ayden, near the Greene County and Pitt County line (fig. 27). Wells were installed at this site on the side of a broad, gently sloping hill in an uncultivated grassy field (fig. 27). Most of the surrounding area is cultivated farm fields and woodland.

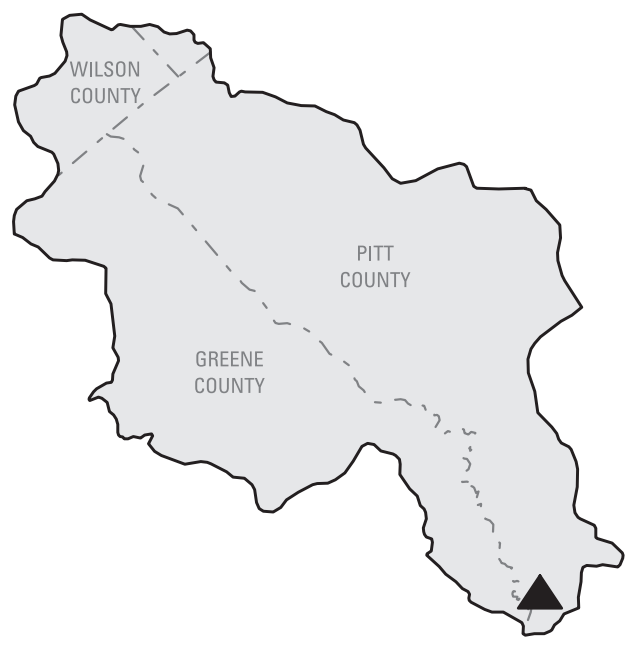

LOCATION OF SCUFFLETON AQUIFER-TEST SITE IN THE LITTLE CONTENTNEA CREEK BASIN
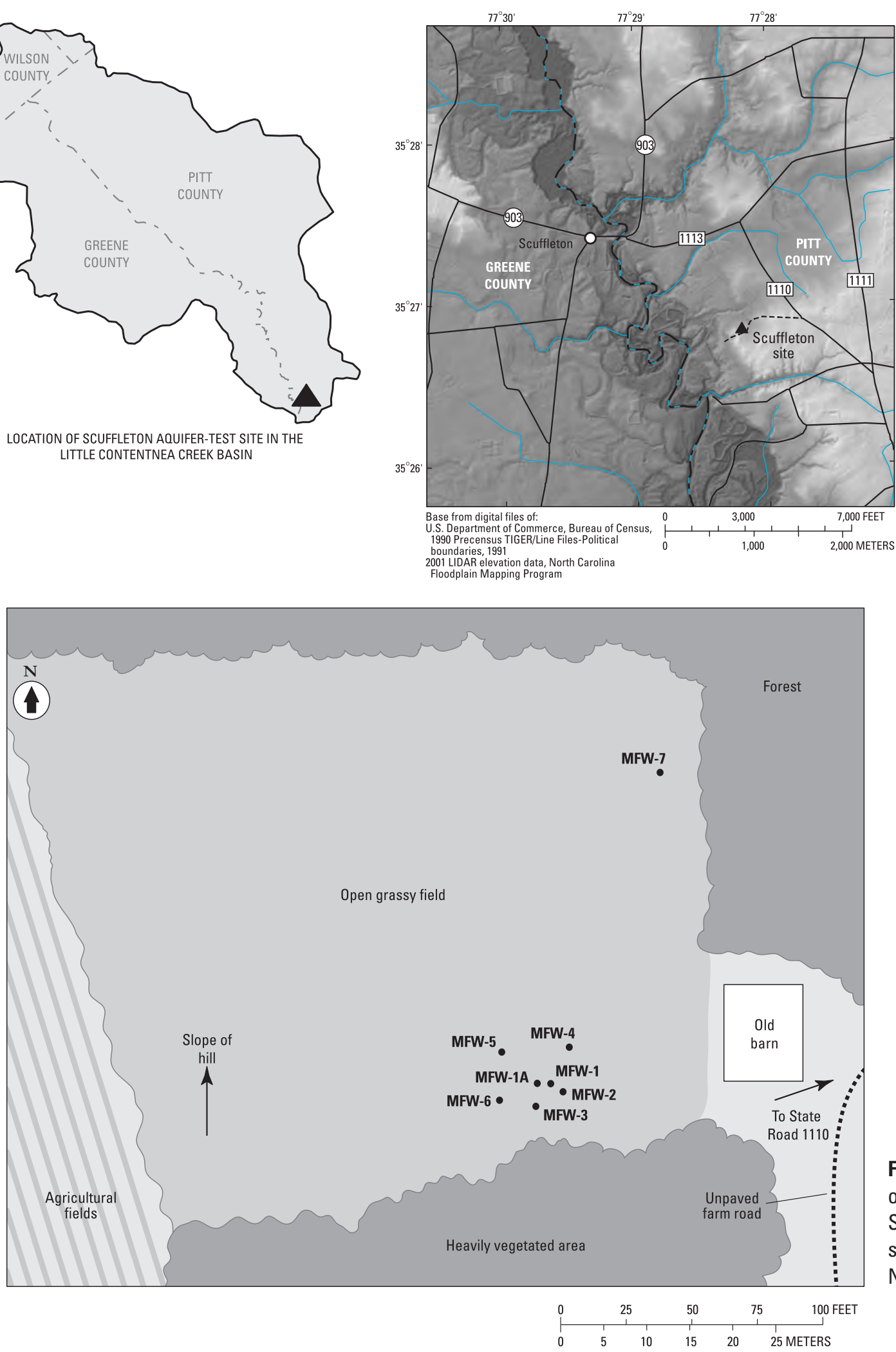

Figure 27. Locations of wells at the Scuffleton aquifer-test site in Pitt County, North Carolina. 


\section{Test Design}

Wire-line core samples and geophysical logs were collected to a depth of about $68 \mathrm{ft}$ below land surface at the Scuffleton site. Geophysical well logs and field descriptions of core samples that were collected at this site are shown in figure 28. The core samples and well logs indicate that the surficial aquifer at the Scuffleton site is composed of several different layers. Each of these layers contains a mixture of sediment particles with grain sizes ranging from sandy silt to medium and slightly gravelly sands. In general, sediment layers in the upper $20 \mathrm{ft}$ at the Scuffleton site have higher sand content than underlying sediments, and the sediment layers from 20 to $42 \mathrm{ft}$ below land surface have higher clay content than the overlying sediments. A well-defined cemented layer with shell fragments is present from about 42 to $43 \mathrm{ft}$ below land surface. Clay layers or sediments high in clay content are present from 43 to about $52 \mathrm{ft}$ below land surface. Although poor recovery occurred in the collection of core samples from 54 to $64 \mathrm{ft}$ below land surface, geophysical logs indicate the presence of sediments high in sand content in this zone. No core samples were recovered from 64 to $68 \mathrm{ft}$ below land surface, and sediments within this zone were reported as hard by the driller. Because of construction problems, the original core hole at the Scuffleton site was abandoned and filled with bentonite grout. After abandoning the original core hole, a deep well was installed at the site to provide a means of monitoring water levels in sediments underlying the surficial aquifer. This well was drilled to a depth of about $60 \mathrm{ft}$ and screened from 55 to $60 \mathrm{ft}$ below land surface (table 4). The pumping well and all shallow observation wells were drilled to a depth of about $42 \mathrm{ft}$ below land surface.

Prior to conducting the aquifer test at the Scuffleton site, experimentation with well-construction materials had taken place at the Ballards Crossroads aquifer-test site. As a result, a new well (MFW-1A) was installed at the Scuffleton site to serve as the pumping well. Well MFW-1A (fig. 29), installed after all other wells at the site had been completed, was constructed with a \#20-slot well screen and coarse sand placed in the annular space of the screened interval. The well that originally had been drilled to serve as the pumping well (well MFW-1; fig. 29) was constructed with a \#10-slot screen and was used as an observation well during the aquifer test (table 4).

Water-level data collected during the aquifer test at the Scuffleton site indicate that the surficial aquifer responded to pumping as if it were composed of two layers, each having different water-bearing characteristics. During the aquifer test, the rate of drawdown in well MFW-1A increased when the water level dropped about $20 \mathrm{ft}$ below land surface (fig. 30). This indicates that the sediments forming the upper $20 \mathrm{ft}$ at the Scuffleton site are capable of producing relatively more water than the deeper, finer grained sediments. As a result, the aquifer properties derived from this test are considered to represent a composite of these two different layers.

An abandoned, shallow well, located $128 \mathrm{ft}$ northeast of the test site (figs. 27, 29), was selected for monitoring background water levels in the surficial aquifer throughout the duration of the aquifer test. The total depth of this well was measured at $29.8 \mathrm{ft}$ below land surface. During the course of the aquifer test, $1.07 \mathrm{ft}$ of drawdown was measured in this well, indicating that the well was affected by pumping during the aquifer test. After observing drawdown in this well, an attempt was made to find another nearby, unused, shallow well that was located outside the influence of pumping. No other accessible shallow wells were found near the test site, however. During analysis of aquifer-test data, the abandoned well that originally had been selected for use as a background well was used as an additional observation well (MFW-7). With no other nearby shallow wells readily available, continuous water-level data recorded during the aquifer test at two shallow wells near the Lizzie Research Station (fig. 1) were used to provide background water-level information for the surficial aquifer at the Scuffleton site test. These wells were less than $22 \mathrm{ft}$ deep and were located about 7 miles northwest of the Scuffleton test site.

\section{Results}

The aquifer test at the Scuffleton site was conducted during March 3-5, 2003, over a period of 48 hours. During this test, water was withdrawn from well MFW-1A at a rate of $13.6 \mathrm{gal} / \mathrm{min}$. During the aquifer test, water pumped from the aquifer was discharged about $350 \mathrm{ft}$ north of the test site at the edge of the wooded area downgradient from the test wells. The saturated thickness of the two-layered composite aquifer measured $34.3 \mathrm{ft}$ at the beginning of the test. Water levels measured by recording equipment in the two shallow background wells at the Lizzie Research Station fluctuated less than $0.25 \mathrm{ft}$ during the aquifer test. No corrections were made to the drawdown data collected in the observation wells as a result of water levels recorded in the background wells. Water levels measured in the deep well, MFW-6, declined by $0.05 \mathrm{ft}$ during the test. No corrections were made to the drawdown measured in the observation wells based on waterlevel changes measured in the deep well. 


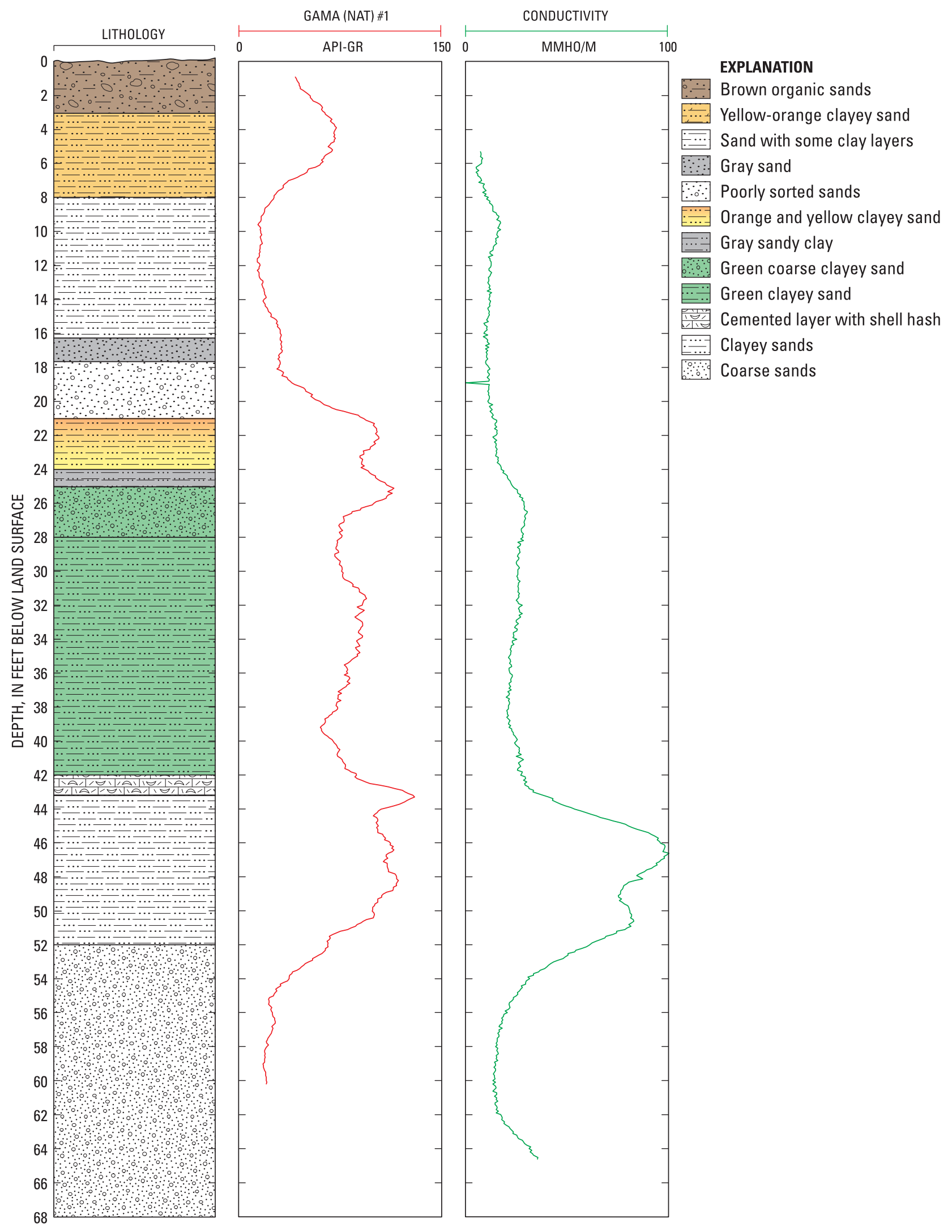

Figure 28. Field description of subsurface sediment layers and geophysical logs collected at the Scuffleton aquifer-test site in the Little Contentnea Creek basin. 


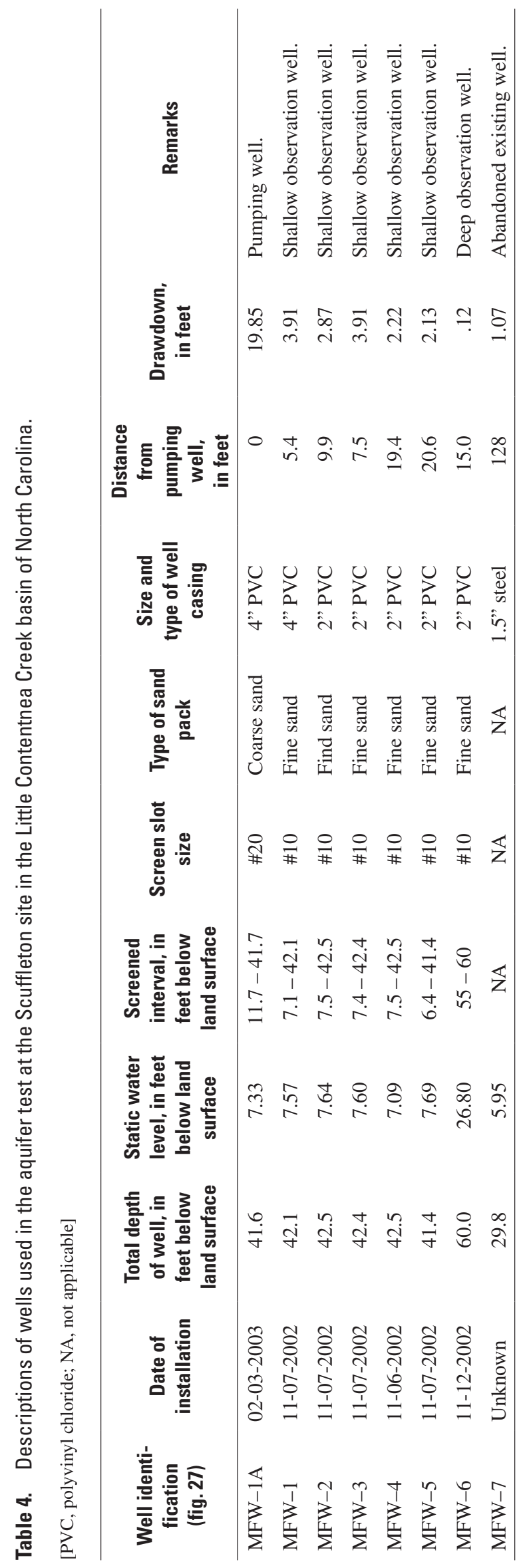




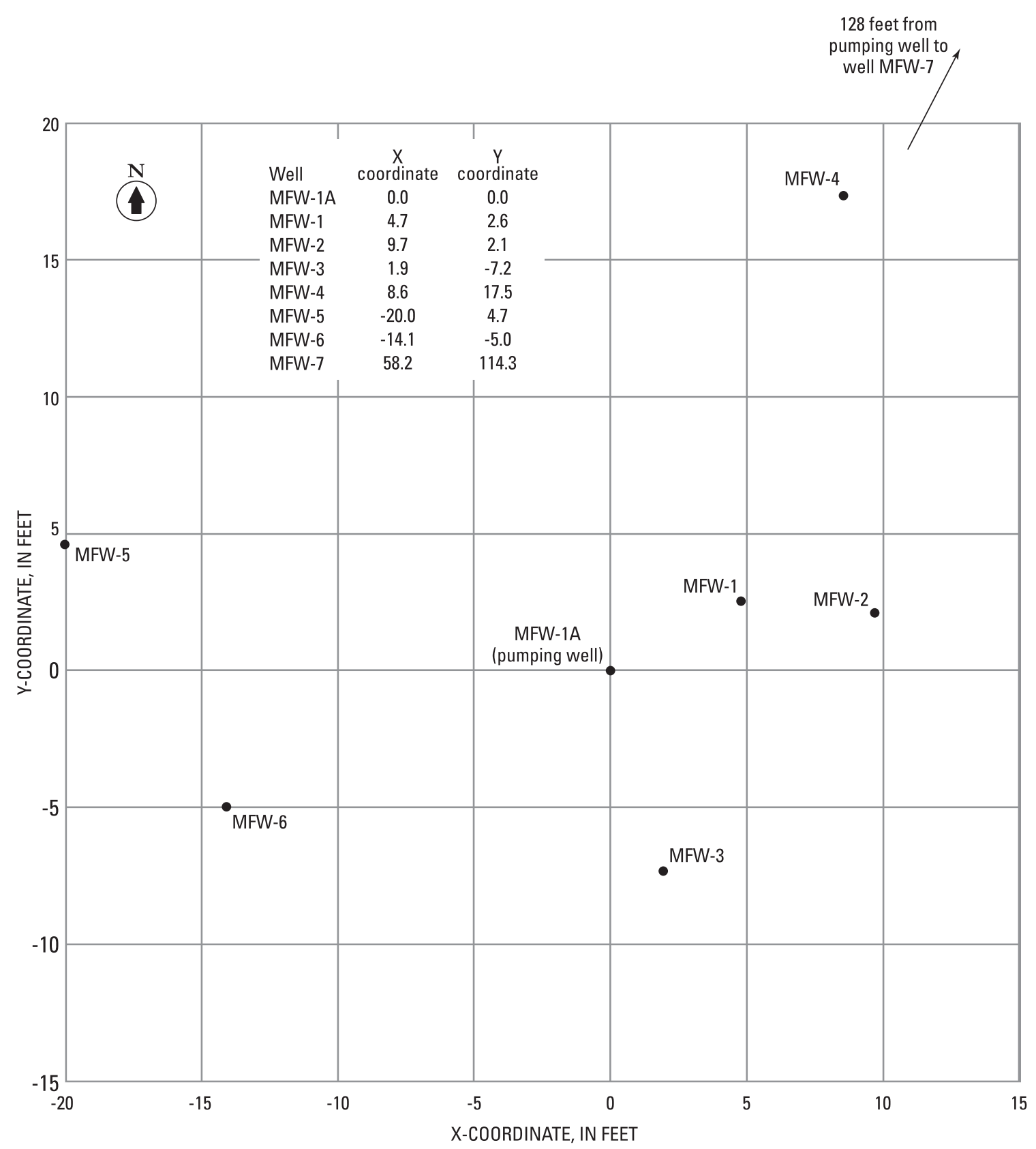

Figure 29. Cartesian coordinates for the pumping well and observation wells at the Scuffleton aquifer-test site. 


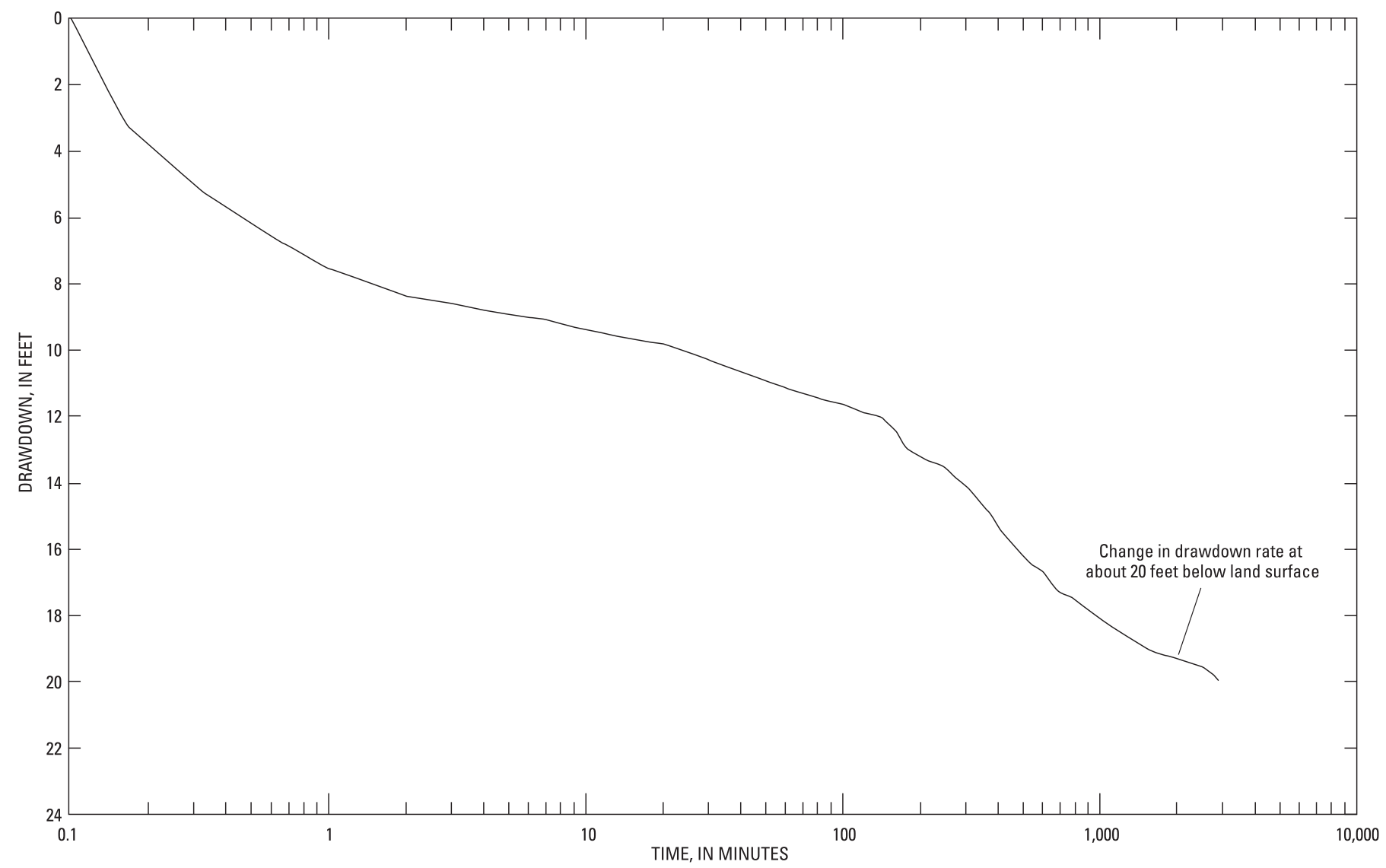

Figure 30. Water level in Scuffleton pumping well MFW-1A showing an increased rate of drawdown after reaching about 20 feet below land surface in the Little Contentnea Creek basin.

Drawdown values calculated for shallow observation wells MFW-1, MFW-2, MFW-3, MFW-4, and MFW-5 were fitted collectively to theoretical curves based on the Neuman (1974) and Moench (1997) solutions (figs. 31 and 32, respectively). Excluding the pumping well (MFW-1A), transmissivity estimates of 450 and $500 \mathrm{ft}^{2} / \mathrm{d}$ were calculated for the test, the highest determined during this investigation (table 2). Similar fits to the data were obtained from both the Neuman (1974; fig. 31) and Moench (1997; fig. 32) solutions as evidenced by the low value (zero) for wellbore storage. Specific yield calculated for the Scuffleton site was 6 percent, which is representative of clayey sediments (Walton, 1970).

If the upper $20 \mathrm{ft}$ of sediments at the Scuffleton site had been tested independently, the hydraulic properties may have differed from those determined for the two-layered composite aquifer. The more linear response of the drawdown data during intermediate time (below the analytical type curves) may be a result of these differences in aquifer properties at depth.

\section{Slug Tests}

In May 2004, slug tests were conducted on all shallow wells at the Scuffleton site (appendix 1C). A solid slug was used to produce both falling (slug-in) and rising (slug-out) head tests in each shallow well. Because water levels in the shallow observation wells were below or near the top of the well screen, only rising head tests were used to calculate hydraulic conductivity estimates for the Scuffleton site. Also, because of the substantial change in saturated thickness of about 56 percent during the aquifer test, hydraulic conductivity is not reported from the Neuman (1974) and Moench (1997) solutions. Slug tests performed on well MFW-1 produced erratic water-level data and excessively high estimates of hydraulic conductivity. As a result, slug test results from well MFW-1 were not used to calculate an average hydraulic conductivity for the site. Hydraulic conductivity values derived from application of the Bouwer and Rice (1976) analytical solution to the slug test data ranged from 0.9 to $6.6 \mathrm{ft} / \mathrm{d}$ and averaged $3.3 \mathrm{ft} / \mathrm{d}$ (table 2). 


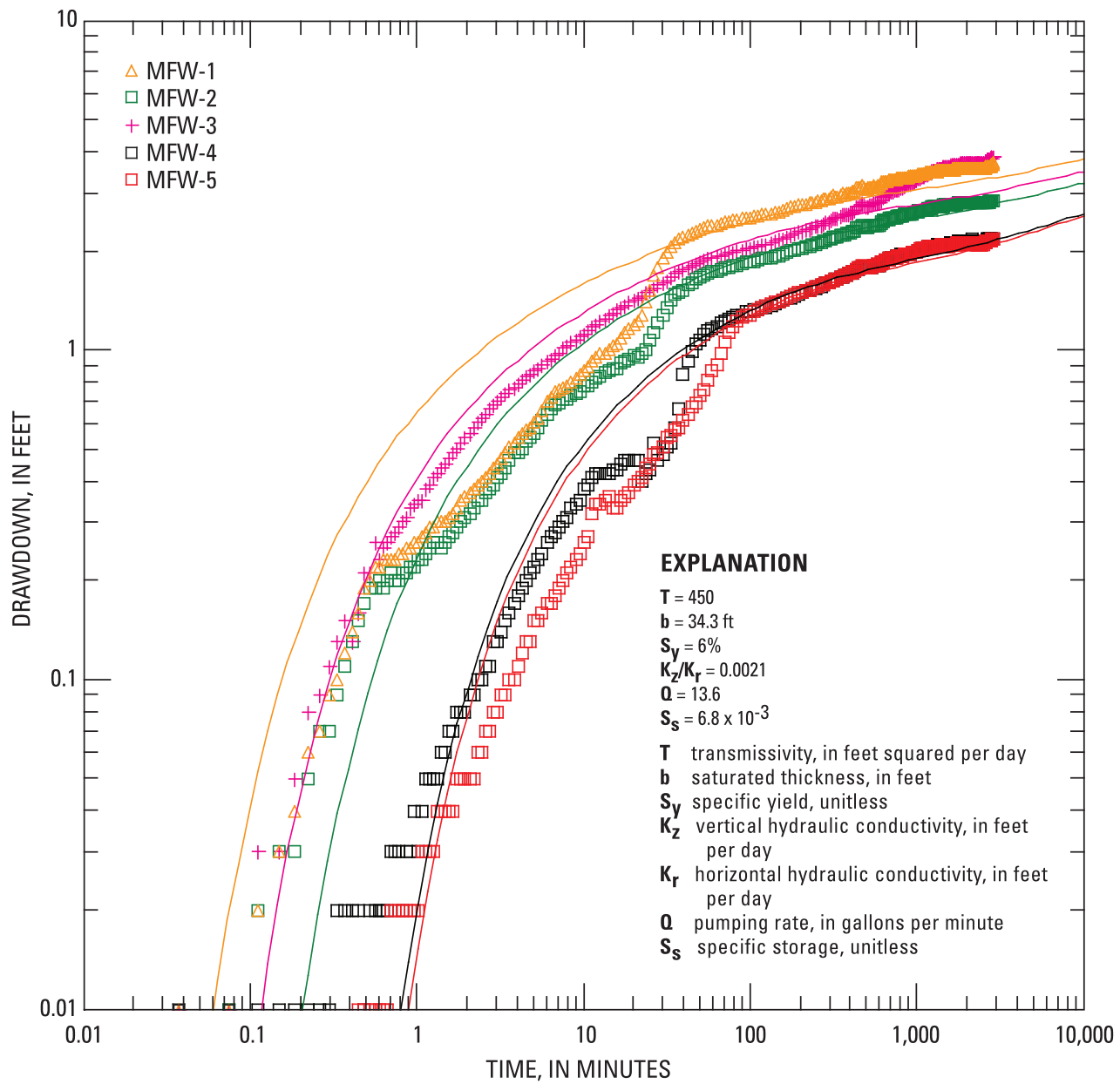

Figure 31. Drawdown data from observation wells during the Scuffleton site aquifer test matched to the Neuman (1974) solution. 


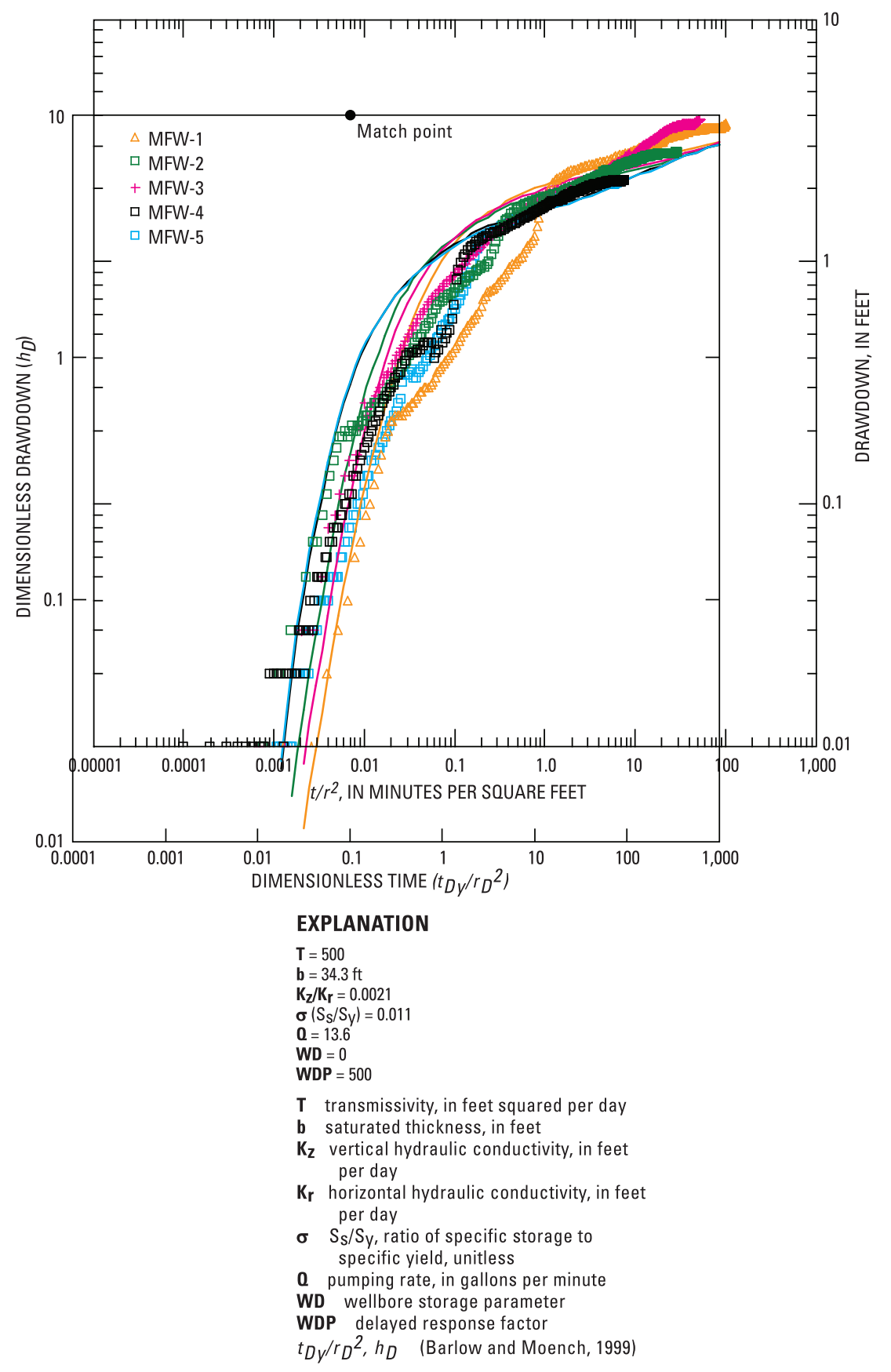

Figure 32. Moench (1997) type-curve overlay for the Scuffleton site aquifer test. 


\section{Ballards Crossroads Site (Valley Flat or Flood Plain)}

The Ballards Crossroads test site is located on a broad flood plain or valley in Pitt County near the intersection of Ballards Crossroads Road and Pocosin Road, about 2 miles south of Ballards Crossroads and 6 miles west of the town of Winterville (fig. 33). Wells at this site were installed within $100 \mathrm{ft}$ of Ballards Crossroads Road on a site once occupied by an old house (fig. 33). Ruins from the old house are a few feet east of where the nearest observation well was installed. Cultivated farm fields occupy most of the surrounding area.

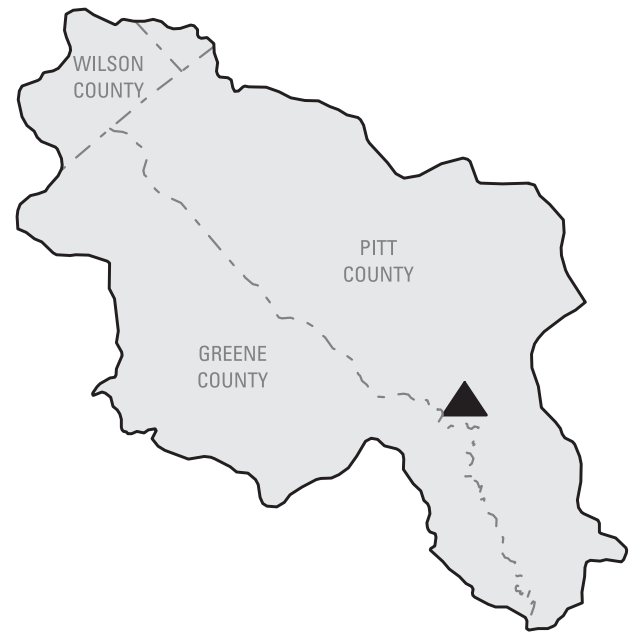

LOCATION OF BALLARDS CROSSROADS AQUIFER-TEST SITE IN THE LITTLE CONTENTNEA CREEK BASIN
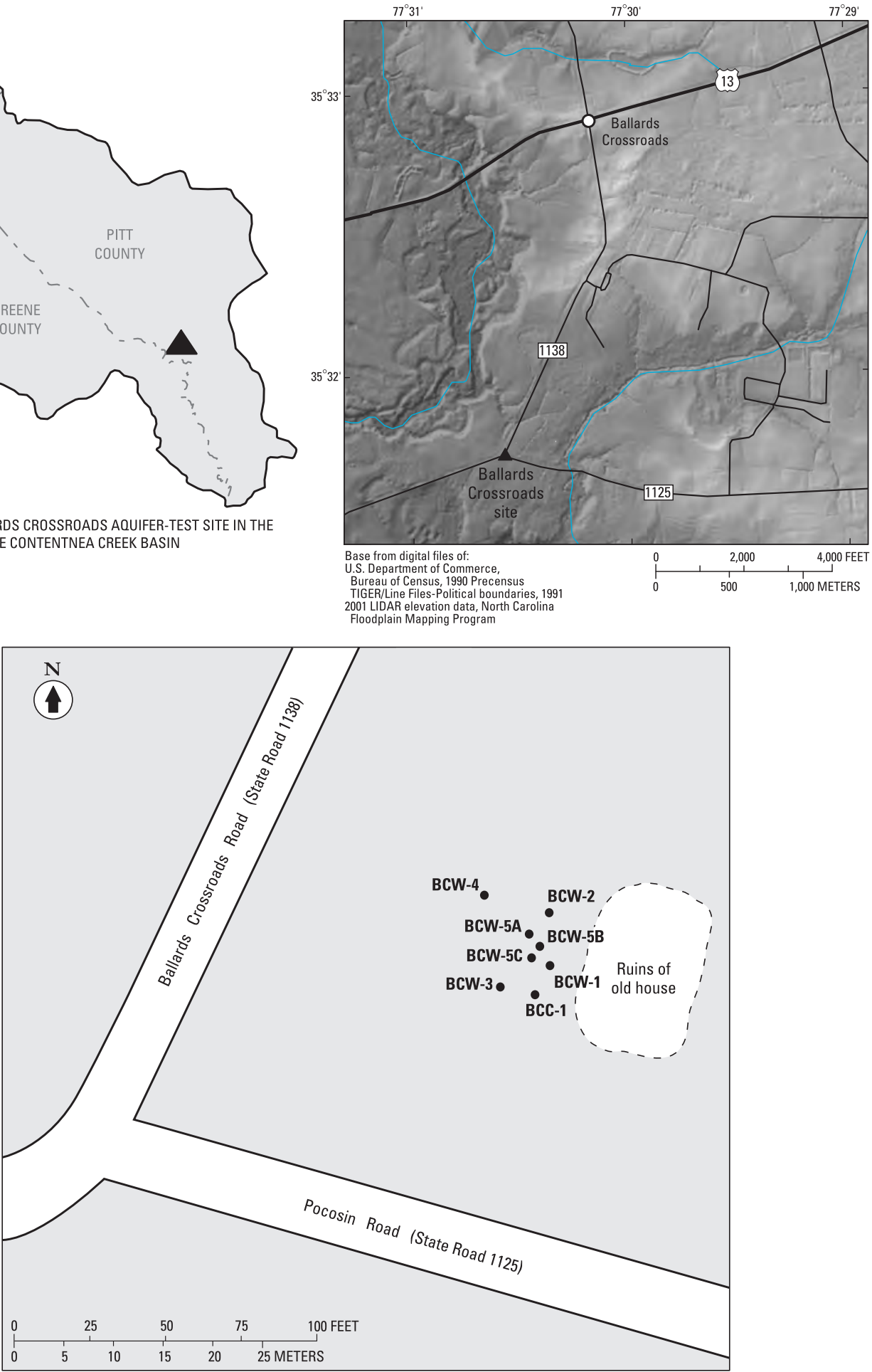

Figure 33. Locations of wells at the Ballards Crossroads aquifer-test site in Pitt County, North Carolina. 
Several farm drainage ditches are in the fields adjacent to the test site, although all of the drainage ditches near the site were dry during the aquifer test.

\section{Test Design}

At the Ballards Crossroads site, wire-line core samples and geophysical logs were collected to a depth of about $56 \mathrm{ft}$ below land surface. Geophysical well logs and field descriptions of the core samples collected at the site are shown in figure 34. Core samples and well logs indicate that the surficial aquifer at the Ballards Crossroads site is composed of multiple sediment layers. These layers contain a mixture of sediment particles with grain sizes ranging from silty sand to medium-grained and gravelly sand. A well-defined confining layer composed of gray clay is about $15 \mathrm{ft}$ below land surface, marking the lower boundary of the surficial aquifer. Sediments high in clay content are present in the core samples collected from 15 to $39 \mathrm{ft}$ below land surface. Although predominantly composed of clay, some thin layers of very coarse sand and shell hash are present from 24 to $39 \mathrm{ft}$ below land surface. Some shell hash and gravel are present in samples collected from 39 to $48 \mathrm{ft}$, and most of the sediments below $39 \mathrm{ft}$ are high in sand content. Green silty sands and fine sandy clay were observed from 48 to $56 \mathrm{ft}$ below land surface. After collecting geophysical logs and core samples, well screen and casing were installed in the core hole to provide a means of monitoring water levels in sediments underlying the surficial aquifer. The deep well, BCC-1, was screened from 20.6 to $30.6 \mathrm{ft}$ below land surface (table 5).

While wells were being installed, an experiment was conducted at the Ballards Crossroads site where well screen openings and sand pack materials were varied to increase well yield from the pumping well. Three 4-inch-diameter PVC wells, with different combinations of screen-slot size and sand pack, were installed at the site. These three wells were installed closely spaced in the center of the test site so that any of the wells could serve as the pumping well for a subsequent aquifer test (fig. 33). Well BCW-5A was constructed with a \#10-slot well screen, and fine sand was backfilled into the annular space around the well screen. Well BCW-5B was installed with a \#10-slot well screen, and coarse sand was backfilled into the annular space of the screened interval. Well BCW-5C was installed with a \#20-slot well screen, and coarse sand was placed in the annular space of the screened interval. While conducting a preliminary test at the site, it was demonstrated that well BCW-5C was capable of producing more water from the surficial aquifer than wells $\mathrm{BCW}-5 \mathrm{~A}$ and BCW-5B. As a result, well BCW-5C was used as the pumping well during the aquifer test at the Ballards Crossroads site. All three 4-inch-diameter wells and four additional 2-inchdiameter PVC-cased shallow observation wells were drilled to a depth of about $16 \mathrm{ft}$ below land surface and screened from approximately 6 to $16 \mathrm{ft}$ below land surface (table 5).

An abandoned shallow well about 0.8 mile north of the test site was used to record background water levels throughout the duration of the aquifer test. The total depth of the background well was measured at $15.2 \mathrm{ft}$ below land surface (table 5). This well originally was constructed as a small diameter hand-driven well.

\section{Results}

The aquifer test at the Ballards Crossroads site was conducted March 24-25, 2003, for 24 hours. During this test, water was withdrawn from well BCW-5C (fig. 35) at a rate of $2.0 \mathrm{gal} / \mathrm{min}$. Water withdrawn from the aquifer was discharged about $600 \mathrm{ft}$ east of the site into a farm drainage ditch that flowed to the northeast, away from the test site. Saturated thickness measured in the surficial aquifer at the beginning of this test was $13.6 \mathrm{ft}$. Water levels measured in the background well declined by about $0.15 \mathrm{ft}$ during the test, and no corrections were made to the drawdown data collected in the observation wells based on this decline. Water levels measured in the deep well (BCC-1) declined by $0.54 \mathrm{ft}$ during the test, indicating that some leakage may have occurred across the confining layer underlying the surficial aquifer at the site. No corrections were made to the drawdown measured in the observation wells based on water-level changes measured in the deep well.

Drawdown values calculated for shallow observation wells BCW-1, BCW-2, BCW-3, BCW-4, BCW-5A, and BCW-5B (fig. 35) were fitted collectively to theoretical curves based on the Neuman (1974) and Moench (1997) solutions (figs. 36 and 37, respectively). Excluding the pumping well (BCW-5C), transmissivity estimates of 55 and $89 \mathrm{ft}^{2} / \mathrm{d}$ were calculated for the test (table 2). The Neuman (1974) solution represented the slope of the drawdown response fairly well (fig. 36). Specific yield calculated for this site was 2 percent, which is representative of clayey sediments (Walton, 1970).

\section{Slug Tests}

In November 2003, slug tests were conducted on all shallow observation wells at the Ballards Crossroads site (appendix 1D). A solid slug was used to produce both falling (slug-in) and rising (slug-out) head tests in each shallow well. Because of the substantial change in saturated thickness of about 50 percent during the Ballards Crossroads aquifer test, hydraulic conductivity is not reported from the Neuman (1974) and Moench (1997) solutions. Hydraulic conductivity values derived from the slug tests using the Bouwer and Rice (1976) solution ranged from 3.0 to $7.0 \mathrm{ft} / \mathrm{d}$ and averaged $4.6 \mathrm{ft} / \mathrm{d}$ (table 2). 


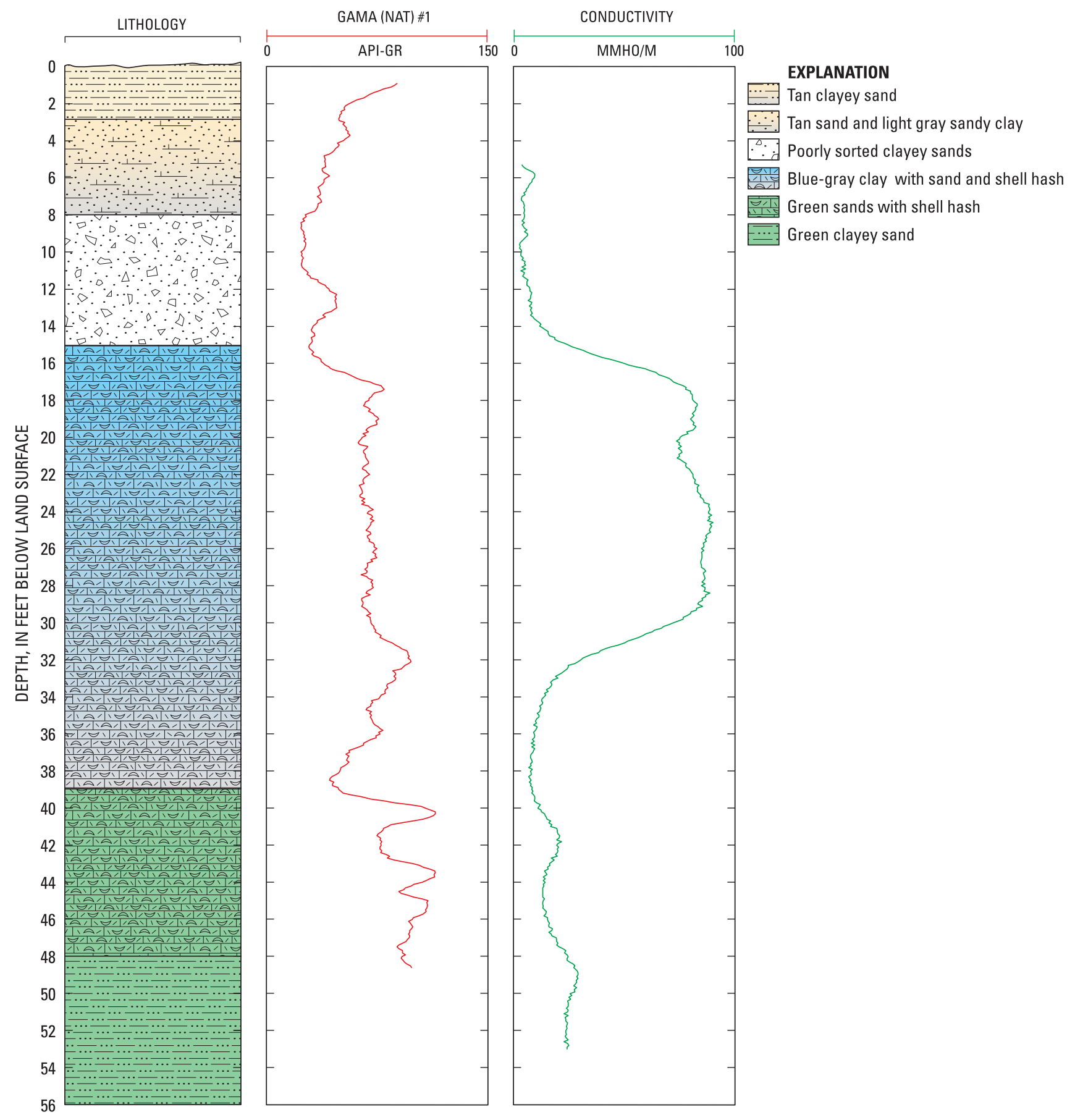

Figure 34. Field description of subsurface sediment layers and geophysical logs collected at the Ballards Crossroads aquifertest site in the Little Contentnea Creek basin. 


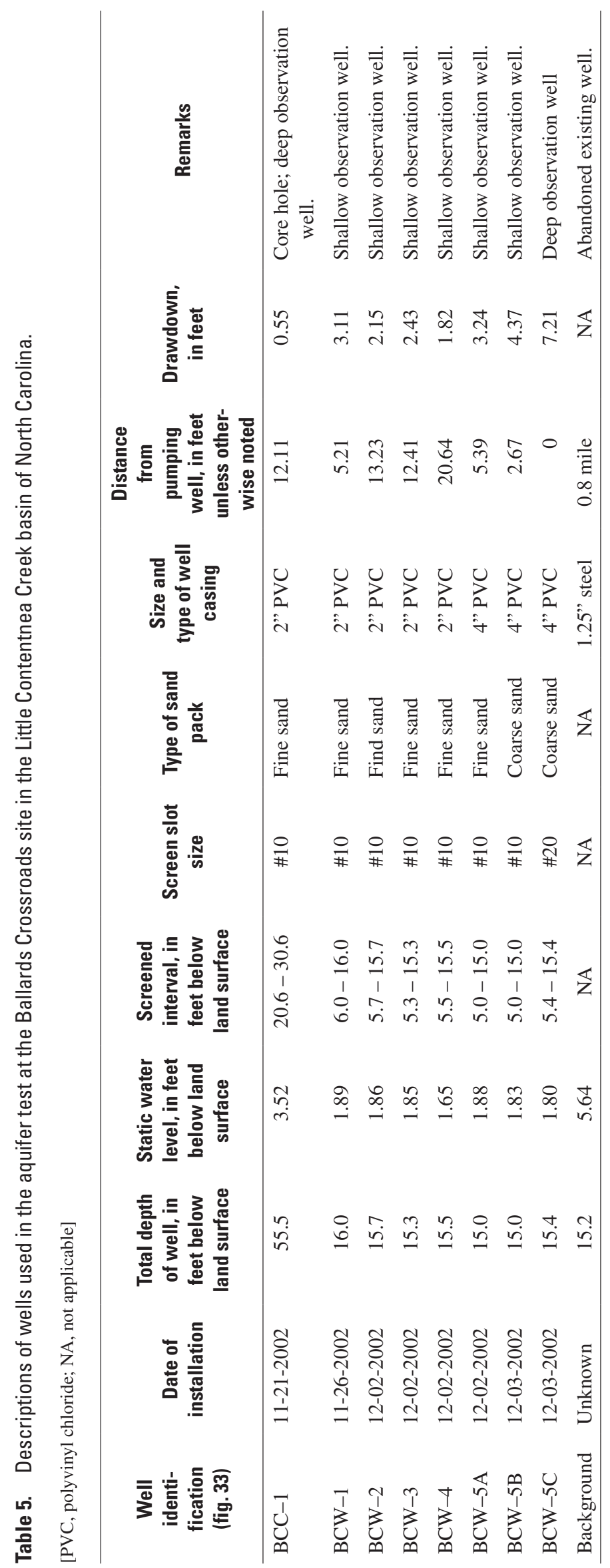




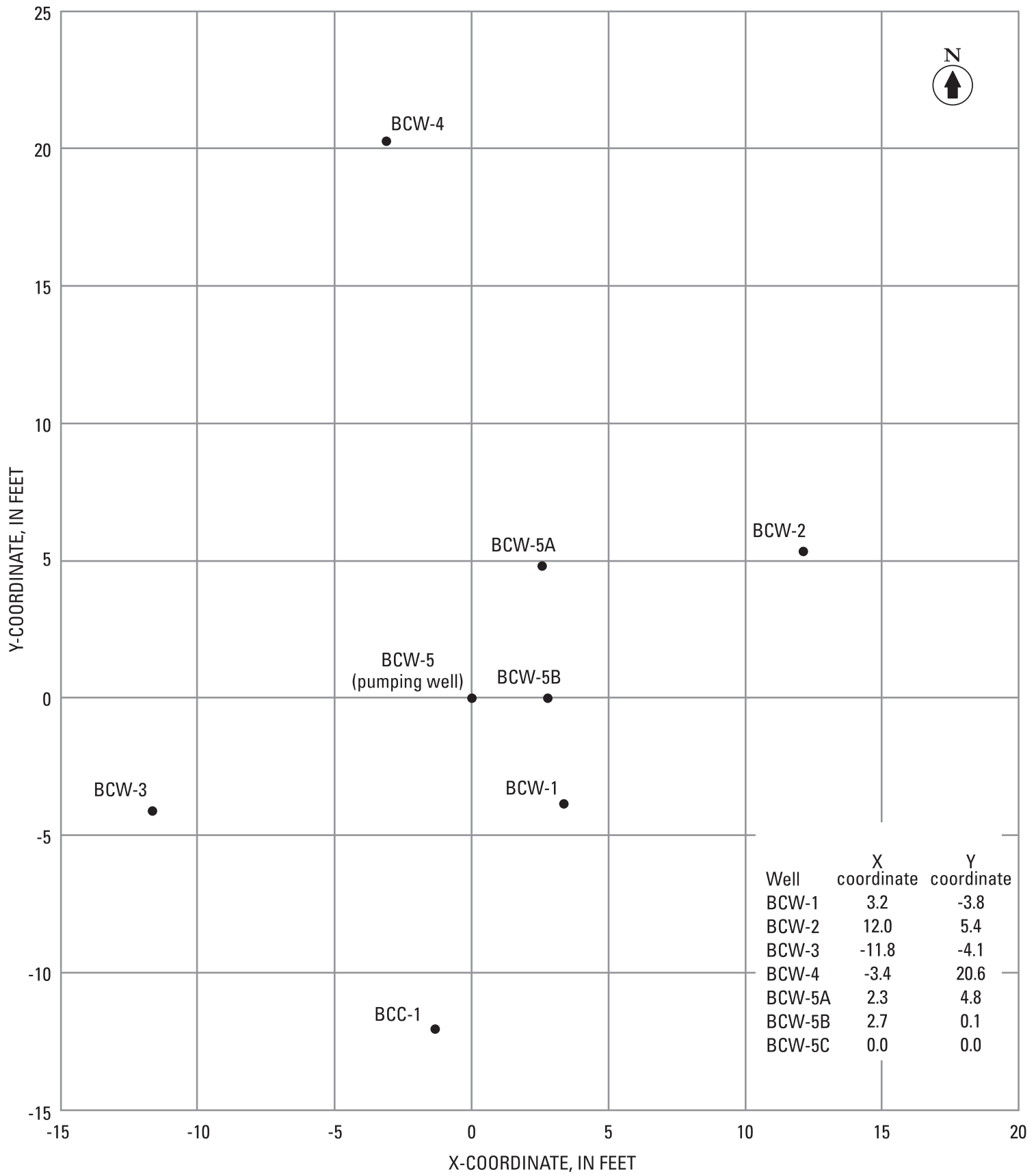

Figure 35. Cartesian coordinates for the pumping well and observation wells at the Ballards Crossroads aquifertest site. 


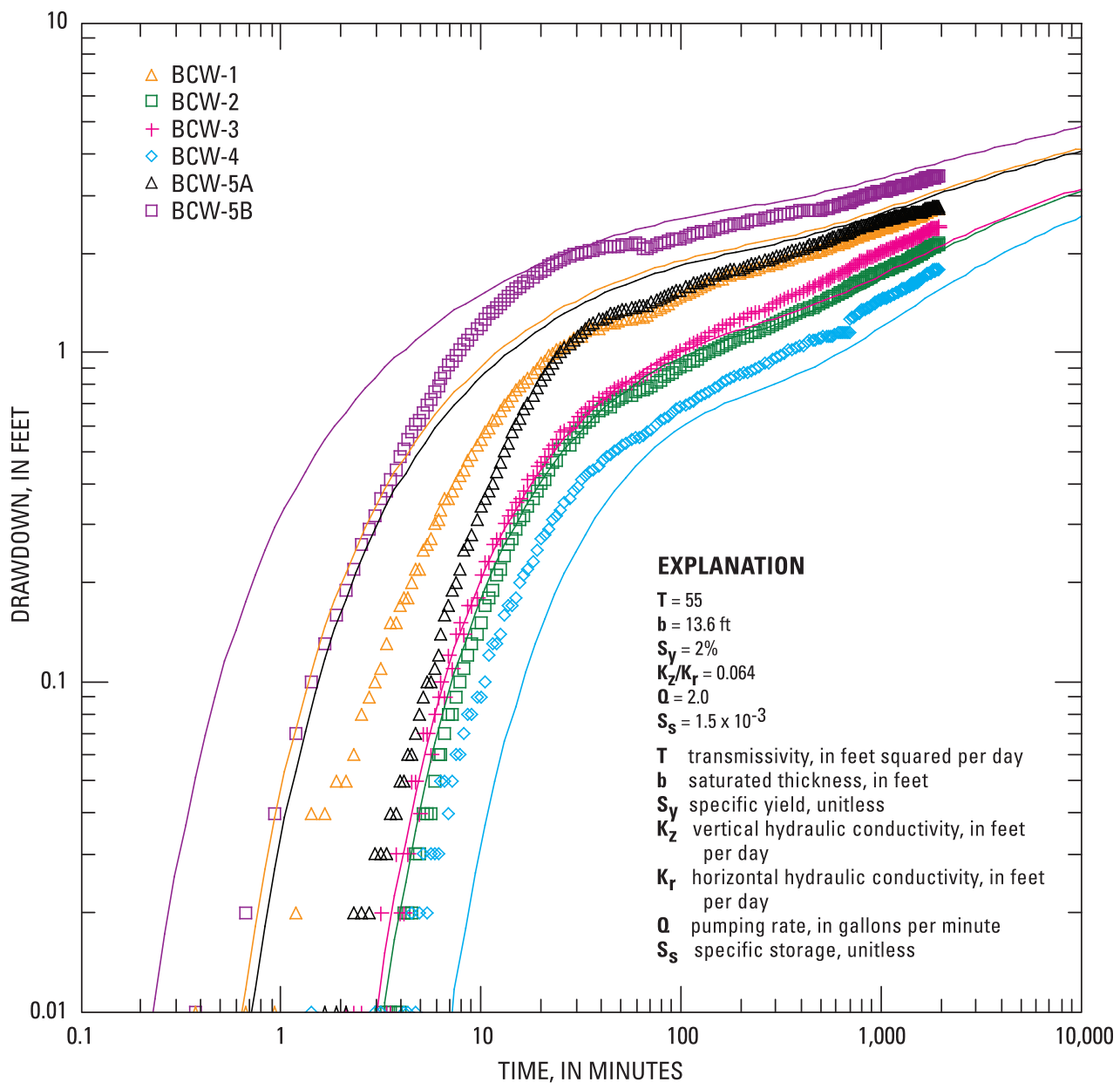

Figure 36. Drawdown data from observation wells during the Ballards Crossroads aquifer test matched to the Neuman (1974) solution. 


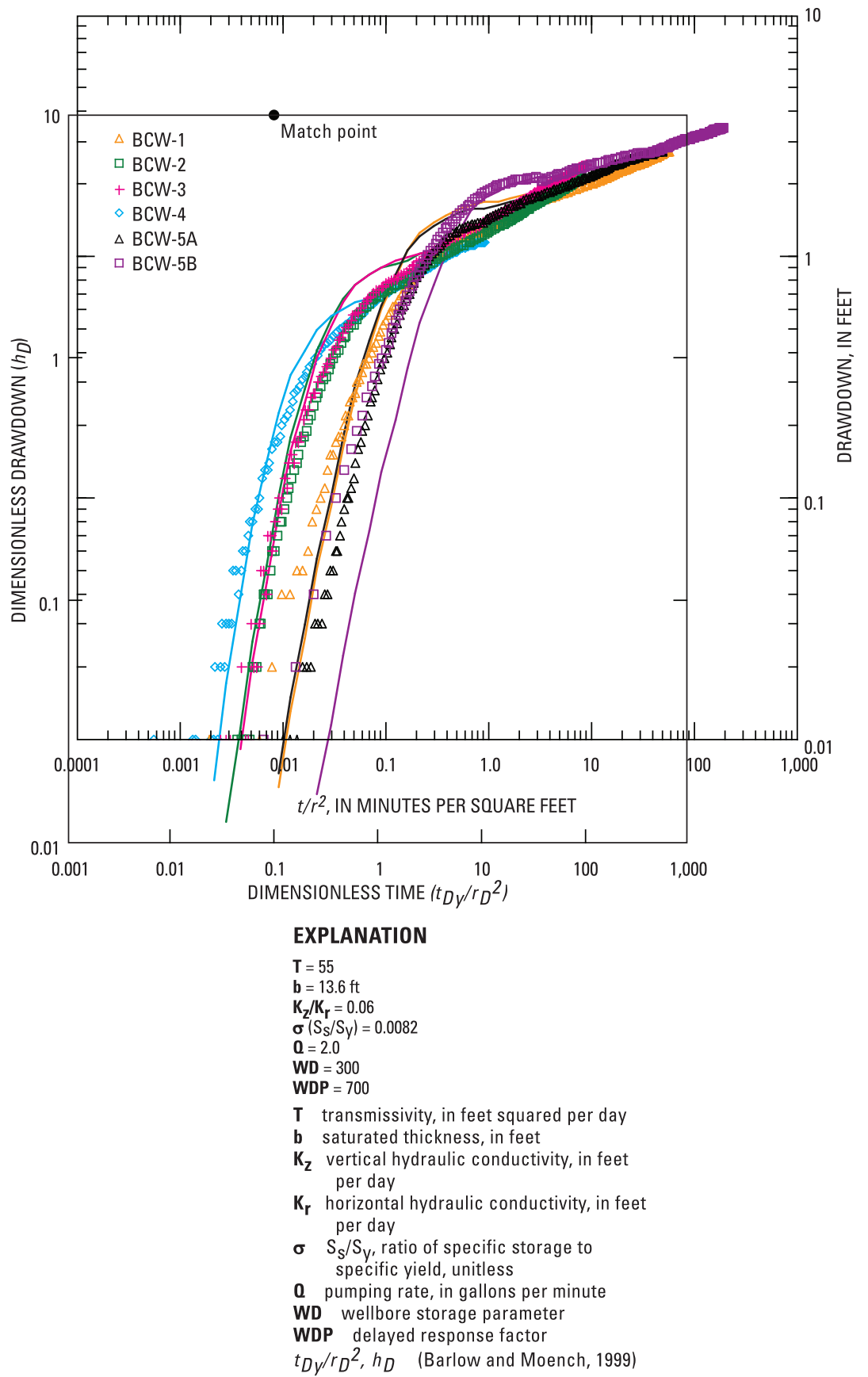

Figure 37. Moench (1997) type-curve overlay for the Balalrds Crossroads site aquifer test. 


\section{Farmville Site (Valley Flat or Flood Plain)}

The Farmville aquifer-test site is located in Pitt County about $600 \mathrm{ft}$ northeast of U.S. Highway 258, just north of the Farmville city limits (fig. 38). At this site, wells were installed in a small clearing on a flat, low-lying wooded area in the Little Contentnea Creek flood plain (fig. 38). All of the surrounding area is heavily wooded. Old demolition debris

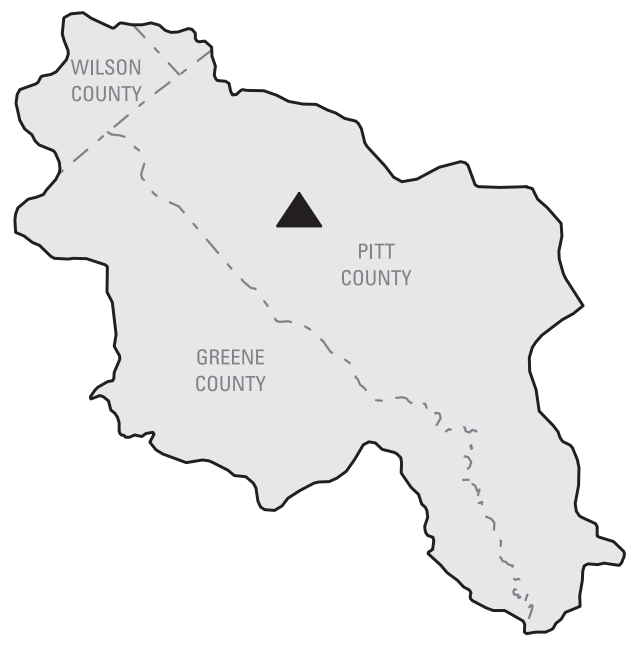

LOCATION OF FARMVILLE AQUIFER-TEST SITE IN THE LITTLE CONTENTNEA CREEK BASIN
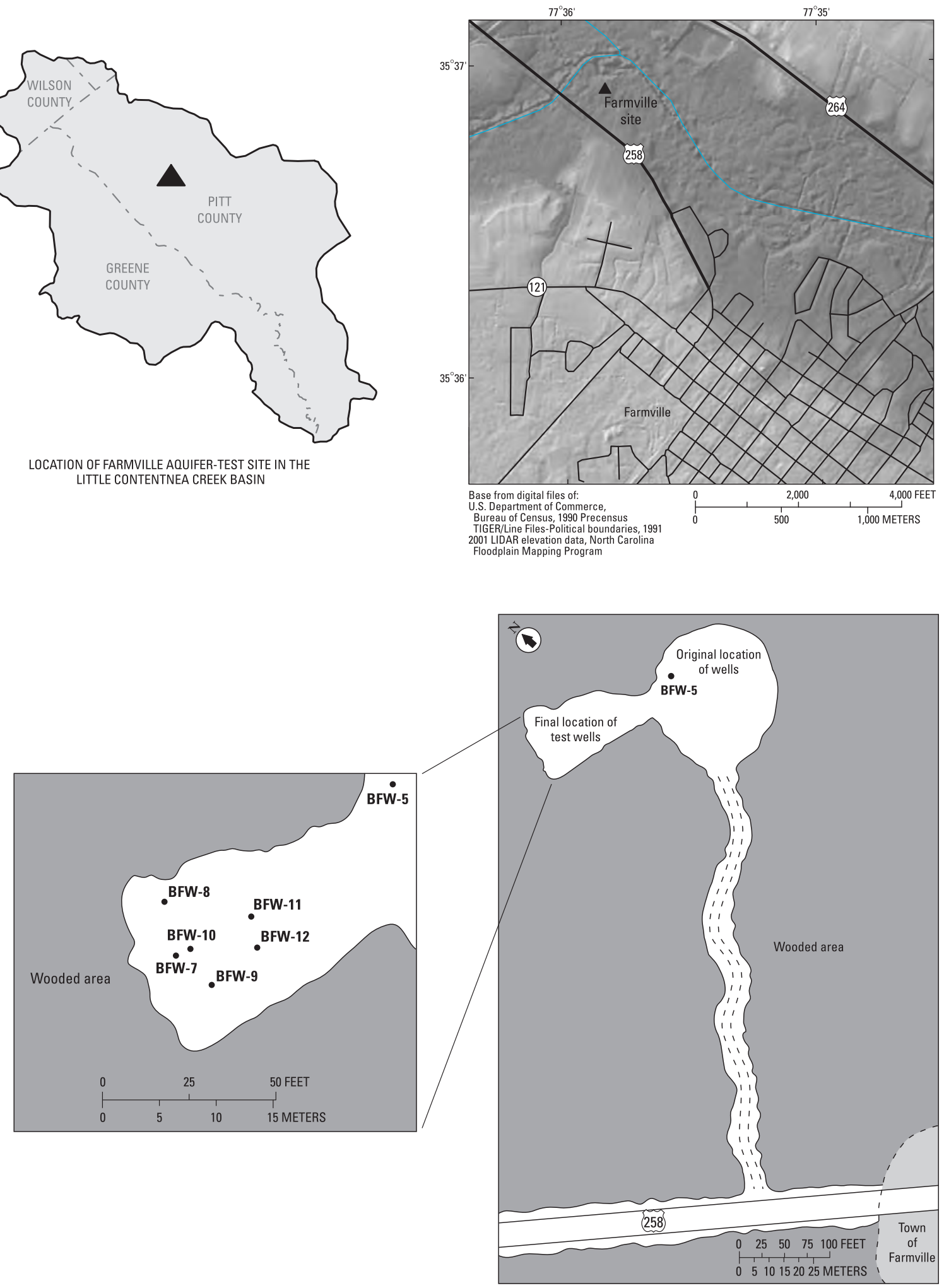

Figure 38. Locations of wells at the Farmville aquifer-test site in Pitt County, North Carolina. 
and other evidence of prior human activity were observed in the wooded area near the test site.

\section{Test Design}

At the Farmville site, wire-line core samples and gamma logs initially were collected from a core hole that was drilled to about $62 \mathrm{ft}$ below land surface. Geophysical well logs and field descriptions of core samples collected at the site are shown in figure 39. Core samples and well logs indicate that the surficial aquifer at this site is composed of multiple sediment layers, each containing a mixture of sediment particles with grain sizes ranging from clayey sand to gravelly sand. The upper $12 \mathrm{ft}$ of sediments at the site are composed of sandy clays and clayey sands. A bluish-gray clay layer is present between 12 and $13 \mathrm{ft}$ below land surface. Other sediment layers high in clay content are present in the core samples from about 12 to $24 \mathrm{ft}$ below land surface, with thin layers of sandy clay and fine sand from 24 to about $32 \mathrm{ft}$ below land surface. Clay layers are present from 32 to $46 \mathrm{ft}$. Clayey and silty sands are present in the core samples collected from 46 to about $62 \mathrm{ft}$ below land surface (fig. 39).

Because of construction problems, the original core hole was abandoned and filled with bentonite grout. Another relatively deep well was drilled to a depth of $53 \mathrm{ft}$ and screened from 48 to $53 \mathrm{ft}$ below land surface. Additional geophysical logs were collected from this deep well, although excessive curvature in the PVC well casing prevented the collection of well logs at depths greater than $27 \mathrm{ft}$ below land surface (fig. 39). Five shallow wells were drilled to a depth of about $24 \mathrm{ft}$ and screened from approximately 9 to $24 \mathrm{ft}$ below land surface.

While performing a preliminary test to establish a sustainable pumping rate for testing the surficial aquifer at the Farmville site, two distinct zones with markedly different water-bearing characteristics were identified in the sediment layers in the upper $24 \mathrm{ft}$. During the preliminary test, sediments above $13 \mathrm{ft}$ below land surface yielded substantially more water than sediment layers below $13 \mathrm{ft}$. As a result, the initial plans for testing all sediment layers in the upper 24 $\mathrm{ft}$ at the Farmville site were canceled, and all but one of the originally installed wells were abandoned. To complete this process, PVC well casings and screens were removed, and the resulting bore holes were backfilled with cement grout.

After abandoning all but one of the originally installed shallow wells, a new site on the same property approximately $100 \mathrm{ft}$ west of the original site was selected for testing. Sediment samples were collected to a depth of about $16 \mathrm{ft}$ at three locations between the original test site and the new test site. These sediment samples indicated that the relative position and characteristics of the shallow sediment layers generally were consistent between the original location and the new test site. Following the collection of core samples at the new test site, another series of shallow wells were installed to a depth of about 12.5 to $13.0 \mathrm{ft}$ below land surface (table 6). One well (BFW-10; fig. 40) was specifically designed to serve as the pumping well and was constructed of 4-inch-diameter PVC casing with a \#20-slot well screen. Four observation wells (BFW-7, BFW-8, BFW-9, and BFW-11; fig. 40) were constructed using 2-inch-diameter PVC screen and casing with \#10-slot screens. The pumping well and all four observation wells were screened from about 3 to $13 \mathrm{ft}$ below land surface. Well BFW-5, the remaining well at the original test site, was used as an additional observation well during the aquifer test and was located about $74 \mathrm{ft}$ from the pumping well (table 6). Because well BFW-5 was screened at a different interval (2.5 to $22.5 \mathrm{ft}$ below land surface), data collected from this well were not used to calculate properties of the surficial aquifer at the Farmville site.

An additional 2-inch-diameter well (BFW-12) was installed to a depth of $21 \mathrm{ft}$ and was screened from 16 to $21 \mathrm{ft}$ below land surface to monitor water levels in the underlying sediment layers. Field observations during construction and drawdown measured in this deeper well during the aquifer test indicate that the screened interval of this well was not isolated from the overlying shallow sediments. Hence, well BFW-12 was not used to evaluate leakage between the different sediment layers or to calculate properties of the surficial aquifer at the test site.

An abandoned shallow well about 2 miles west of the Farmville test site was used to monitor background water levels throughout the duration of the aquifer test. The total depth of this background well was measured at $13.1 \mathrm{ft}$ below land surface (table 6). This well originally was constructed as a 24-inch-diameter bored residential well.

\section{Results}

The aquifer test at the Farmville site was conducted May 20-21, 2003, for a 24-hour period. During this test, water was withdrawn from well BFW-10 (pumping well) at a rate of $6.3 \mathrm{gal} / \mathrm{min}$. During the aquifer test at the Farmville site, water withdrawn from the aquifer was discharged about $200 \mathrm{ft}$ east of the test wells to a low-lying area that was downgradient from the test site. The saturated thickness measured in the surficial aquifer at the beginning of the test was $11.1 \mathrm{ft}$. Water levels in the surficial aquifer measured in the background well declined by about $0.4 \mathrm{ft}$ during the test, and no corrections were made to the drawdown measured in the observation wells based on this decline. During the aquifer test, water-levels measured in the deeper well (BFW-12) declined nearly as much as in the nearest shallow observation well. Since well BFW-12 was not isolated from the overlying sediments, no adjustments or corrections were made to drawdown data from the shallow wells based on the water-levels measured in well BFW-12.

Drawdown values calculated for shallow observation wells BFW-7, BFW-8, BFW-9, and BFW-11 were fitted collectively to theoretical curves based on the Neuman (1974) and Moench (1997) solutions (figs. 41 and 42, respectively). Excluding BFW-10 (the pumping well), transmissivity estimates of 210 and $310 \mathrm{ft}^{2} / \mathrm{d}$ were calculated for the Farmville 


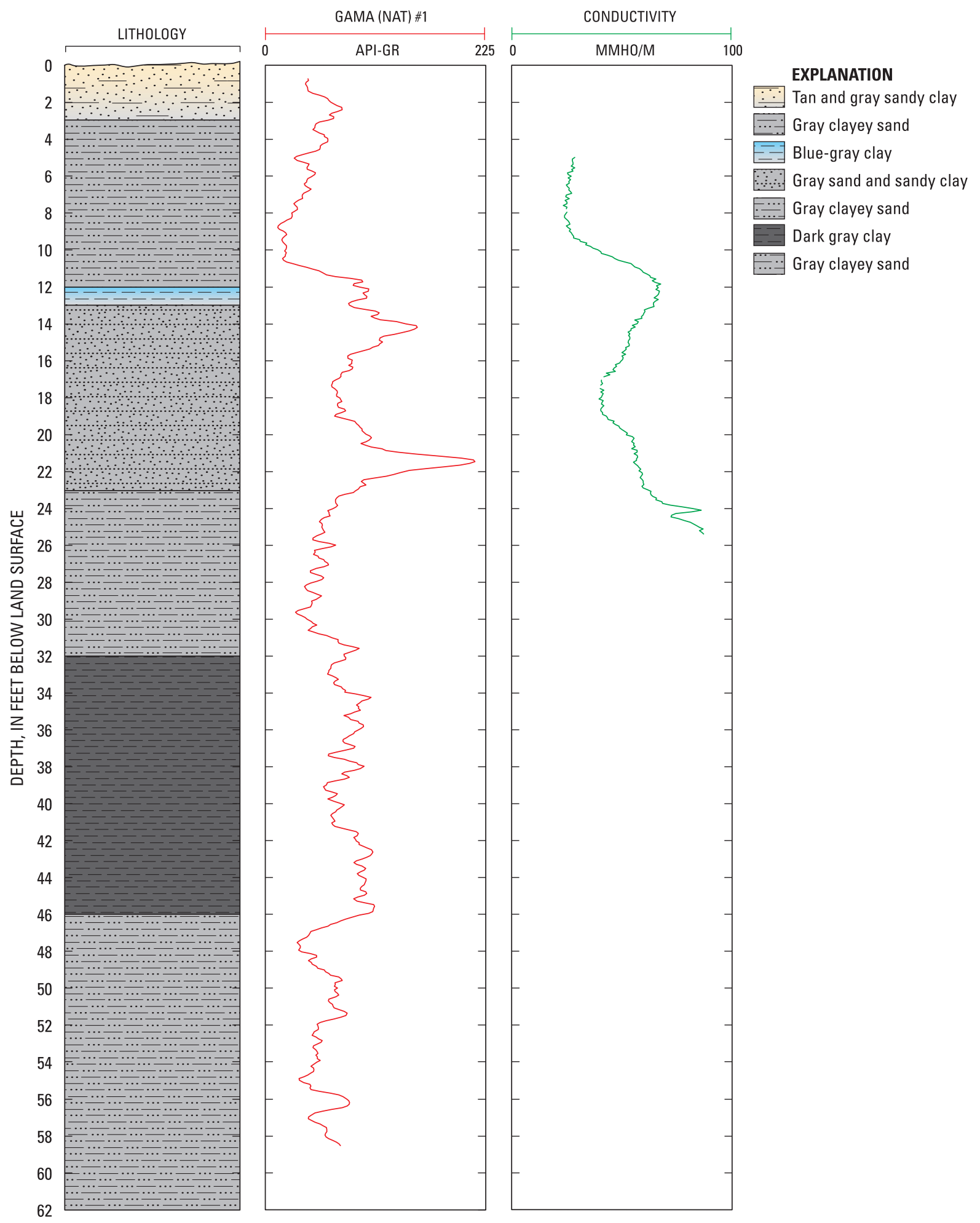

Figure 39. Field description of subsurface sediment layers and geophysical logs collected at the Farmville aquifer-test site in the Little Contentnea Creek basin. 


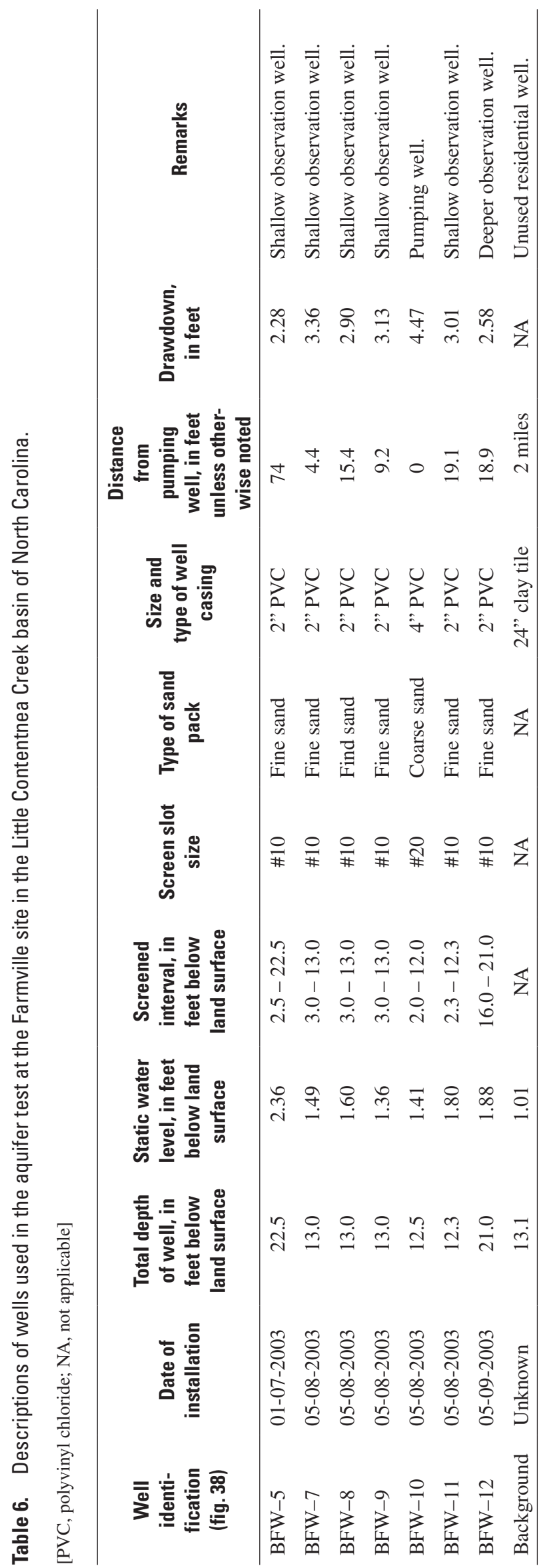




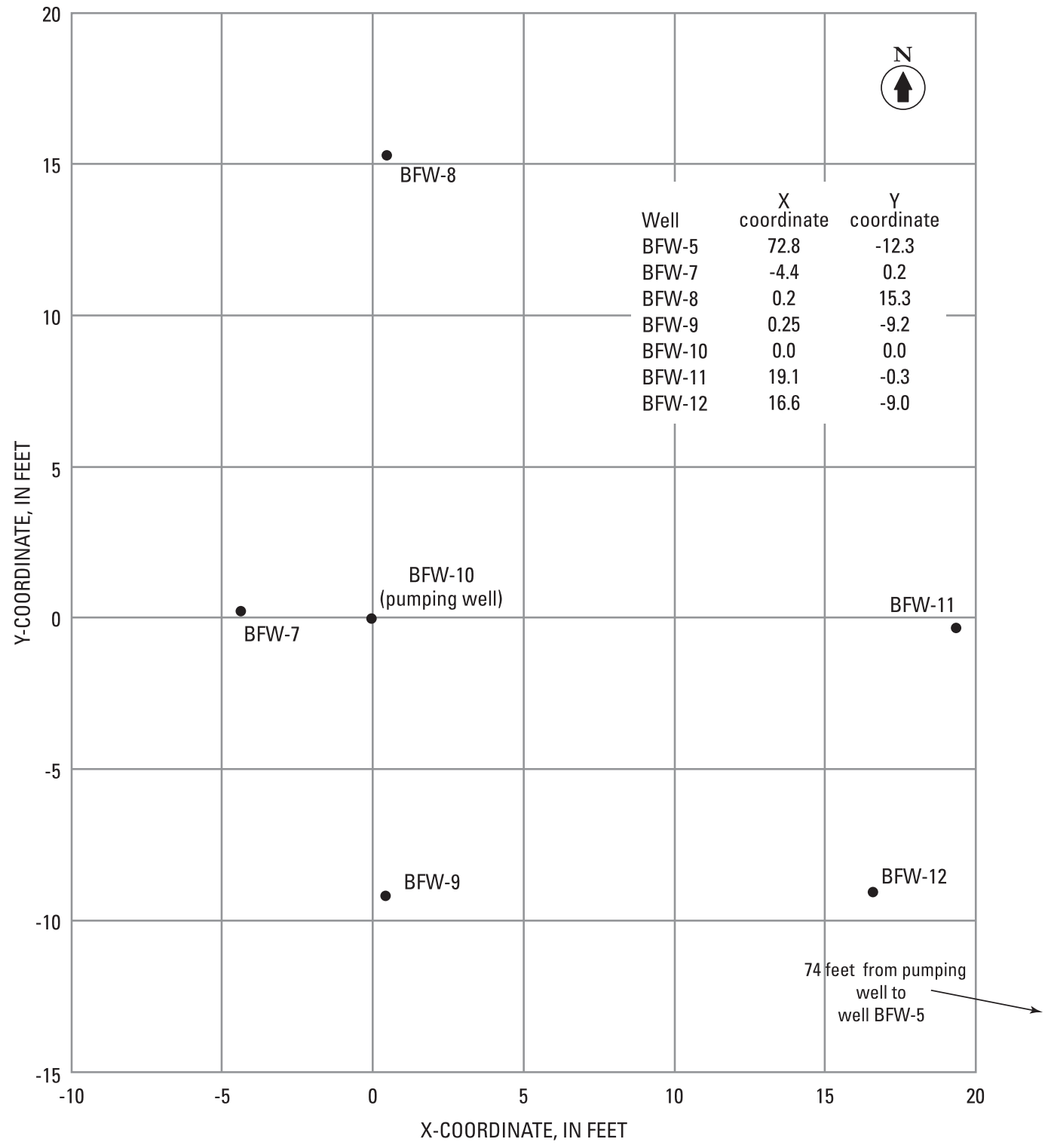

Figure 40. Cartesian coordinates for the pumping well and observation wells at the Farmville aquifer-test site. 


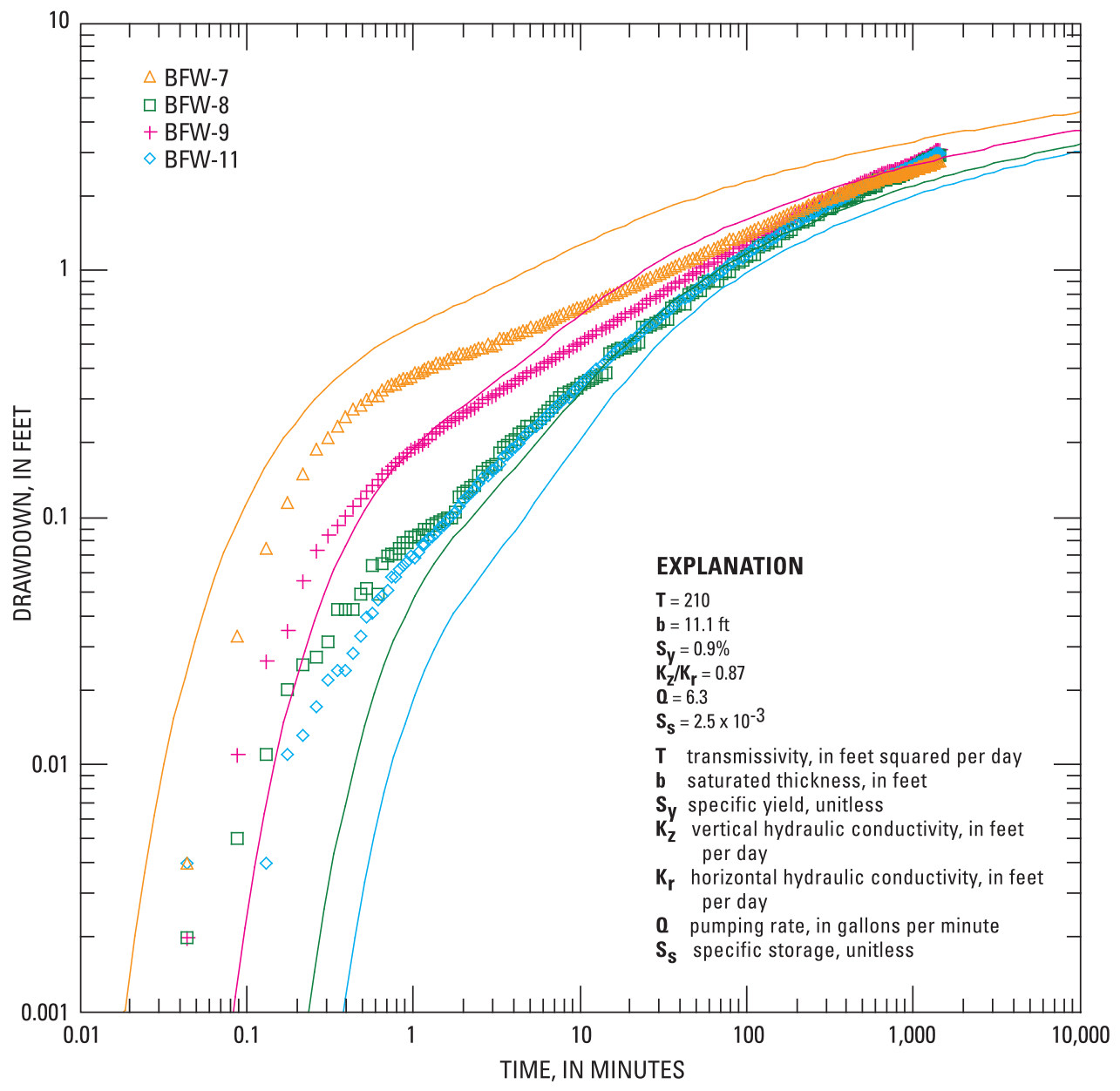

Figure 41. Drawdown data from observation wells during the Farmville site aquifer test matched to the Neuman (1974) solution. 


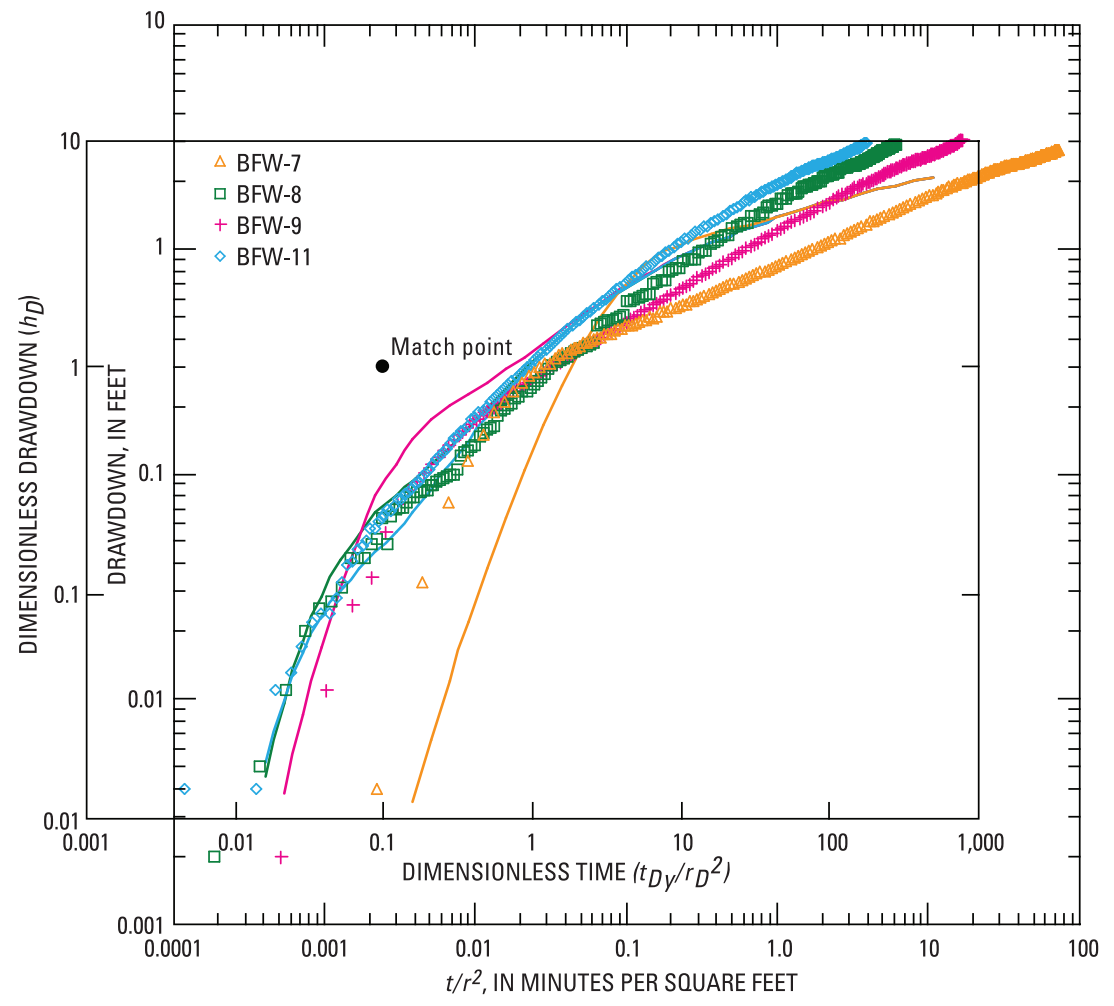

\section{EXPLANATION}

$T=210$

$\mathbf{b}=11.1 \mathrm{ft}$

$\mathrm{K}_{\mathrm{z}} / \mathrm{K}_{\mathrm{r}}=0.87$

$\sigma\left(S_{S} / S_{y}\right)=-0.05$

$\mathbf{0}=6.3$

WD $=50$

WDP $=700$

T transmissivity, in feet squared per day

b saturated thickness, in feet

$\mathbf{K}_{\mathbf{z}}$ vertical hydraulic conductivity, in feet per day

$\mathbf{K}_{\mathbf{r}}$ horizontal hydraulic conductivity, in feet per day

$\sigma \quad \mathrm{S}_{\mathrm{S}} / \mathrm{S}_{\mathrm{y}}$, ratio of specific storage to specific yield, unitless

0 pumping rate, in gallons per minute

WD wellbore storage parameter

WDP delayed response factor

$t_{D Y} / r_{D}{ }^{2}, h_{D} \quad$ (Barlow and Moench, 1999)

Figure 42. Moench (1997) type-curve overlay for the Farmville site aquifer test. 
site (table 2). The $\mathrm{K}_{\mathrm{z}} / \mathrm{K}_{\mathrm{r}}$ value of 0.87 for the type-curve fits is high (fig. 42), indicating a larger vertical component of flow to the pumping well. The type-curve fit for the Neuman (1974) solution matched the late-time drawdown data slope better (fig. 41), while the Moench (1997) solution fit narrowed the observation well time differences (fig. 42). Wellbore storage does not appear to be a large factor during this test (wellbore storage $=50$ ). Neither solution fit the data as well as at the other aquifer-test sites, likely because of the large vertical-flow component. Specific yield calculated for the Farmville site was less than 1 percent, which is representative of clayey sediments (Walton, 1970).

\section{Slug Tests}

In May 2004, slug tests were conducted on all shallow wells at the Farmville site (appendix 1E). A solid slug was used to produce both falling (slug-in) and rising (slug-out) head tests in each shallow well. Because water levels in the shallow observation wells were below the top of the well screen, only rising head tests were used to calculate hydraulic conductivity estimates for the Farmville site. Slug tests performed on well BFW-5 (screened in a different zone from other wells at the site) produced lower-than-expected values of hydraulic conductivity. Slug test results from well BFW-5 were not used to calculate an average hydraulic conductivity estimate for the site. Because of the substantial change in saturated thickness of about 40 percent during the Farmville aquifer test, hydraulic conductivity is not reported from the Neuman (1974) and Moench (1997) solutions. The Bouwer and Rice (1976) analytical solution for unconfined aquifers was used to analyze the slug test data from each well. Hydraulic conductivity values derived from the slug tests ranged from 18 to $26 \mathrm{ft} / \mathrm{d}$ and averaged $21 \mathrm{ft} / \mathrm{d}$ (table 2 ).

\section{Summary}

Hydraulic properties of the surficial aquifer system were determined at five sites located in three different topographic settings in the Little Contentnea Creek drainage basin of the North Carolina Coastal Plain. No relation was found between the topographic setting of the test sites and hydraulic properties of the surficial aquifer. Generally, low values of transmissivity and hydraulic conductivity were determined for the surficial aquifer at each test site.

Each aquifer test was conducted by pumping water from the surficial aquifer at a constant rate for a period of 24 to 72 hours. For each test, a submersible electric pump was used to withdraw water from one well that was constructed to fully penetrate the surficial aquifer. At each site, water levels were measured in the pumping well and in multiple observation wells placed within $25 \mathrm{ft}$ from the pumping well. Pumping rates used for testing the surficial aquifer at the five test sites ranged from 1.8 to $13.6 \mathrm{gal} / \mathrm{min}$. Prior to pumping, water-table depth measured at the five test sites ranged from about 1.4 to
$10.8 \mathrm{ft}$ below land surface. The saturated thickness of the surficial aquifer at most test sites generally was less than $19 \mathrm{ft}$, and the lower boundary of the surficial aquifer (top of the uppermost confining layer) generally was less than $25 \mathrm{ft}$ below land surface.

Transmissivity, hydraulic conductivity, and specific yield were calculated for the surficial aquifer at each of the five test sites. These values were derived by visually and collectively matching drawdown data collected from multiple observation wells at each site to the Neuman (1974) and Moench (1997) solutions using analytical software. The transmissivity estimates determined for the five test sites ranged from 55 to $500 \mathrm{ft}^{2} / \mathrm{d}$. Hydraulic conductivity estimates derived from slug tests (Bouwer and Rice, 1976) for the five test sites ranged from 3.3 to $21 \mathrm{ft} / \mathrm{d}$. Specific yield estimates for the surficial aquifer at each test site ranged from less than 1 percent to 10 percent.

Software-based results of the Neuman (1974) and Moench (1997) solutions were used to derive estimates of hydraulic properties for the surficial aquifer at the five test sites. The Neuman (1974) solution provided a better fit to the late-time data and was used to determine specific yield for the surficial aquifer at each test site. The Moench (1997) solution provided a better overall fit for the data, especially for the early-time drawdown data and observation well response, and provided a better estimate of aquifer transmissivity.

Aquifer properties derived for each site by the Neuman (1974) and Moench (1997) solutions were compared to determine if topographic setting could be used to predict surficial aquifer properties. The lowest transmissivity estimate determined during this investigation was calculated for the Ballards Crossroads site, which is located in a wide valley-flat or flood-plain setting. A transmissivity estimate of $89 \mathrm{ft}^{2} / \mathrm{d}$ and hydraulic conductivity value (slug tests) of $4.6 \mathrm{ft} / \mathrm{d}$ were calculated for this site. For the other flood-plain site (Farmville), a transmissivity estimate of $310 \mathrm{ft}^{2} / \mathrm{d}$ and the highest hydraulic conductivity value determined during this study, $21 \mathrm{ft} / \mathrm{d}$, were derived. A two-layered composite aquifer system was tested at the Scuffleton site, for which the highest transmissivity estimate determined during this investigation, $500 \mathrm{ft}^{2} / \mathrm{d}$, was calculated. The lowest hydraulic conductivity estimate determined during this investigation, $3.3 \mathrm{ft} / \mathrm{d}$, was calculated for the Scuffleton site. If the upper $20 \mathrm{ft}$ of sediments at the Scuffleton site had been tested independently, the hydraulic properties of the upper layers may have differed substantially from those determined for the two-layered composite aquifer.

The area in the Little Contentnea Creek basin has been subjected to multiple sea-level transgressions and regressions, thereby exposing the near-surface sediments to multiple deposition and erosion events. As a result, sediments forming a given topographic feature in one part of the area may have substantially different properties than sediments forming the same type of feature in another area. Likewise, the water-bearing properties of the surficial aquifer in similar topographic settings may differ considerably across the area. Although topography is useful in the general discussion of movement 
and behavior of water, the results from the five sites tested during this investigation indicate that hydraulic characteristics of the surficial aquifer in the Little Contentnea Creek basin cannot be predicted based on topographic setting.

\section{References}

Ator, S.W., Denver, J.M., Krantz, D.E., Newell, W.L., and Martucci, S.K., in press, A surficial hydrogeologic framework for the mid-Atlantic Coastal Plain: U.S. Geological Survey Professional Paper 1680, 83 p.

Barlow, P.M., and Moench, A.F., 1999, WTAQ-A computer program for calculating drawdowns and estimating hydraulic properties for confined and water-table aquifers: U.S. Geological Survey Water-Resources Investigations Report 99-4225, 74 p.

Bouwer, H., and Rice, R.C., 1976, A slug test method for determining hydraulic conductivity of unconfined aquifers with completely or partially penetrating wells: Water Resources Research, v. 12, no. 3, p. 423-428.

Butler, J.J., Jr., 1998, The design, performance, and analysis of slug tests: Boca Raton, FL, Lewis Publishers, 252 p.

Cooper, H.H., and Jacob, C.E., 1946, A generalized graphical method for evaluating formation constants and summarizing well field history: Transaction of American Geophysical Union, v. 27, p. 526-534.

Daniels, R.B., Kleiss, H.J., Buol, S.W., Byrd, H.J., and Phillips, J.A., 1984, Soil systems in North Carolina: Raleigh, North Carolina Agricultural Research Service, Bulletin 467.

Farrell, K.M., Mew, H.E., Jr., Keyworth, A.J., and Clark, T.W., 2003, Comprehensive landscape analysis, geomorphology, and sequence stratigraphy in eastern North Carolina's Little Contentnea Creek watershed of the Neuse River basinMethods for constructing reconnaissance-level geologic maps of a relic Plio-Pleistocene terrane, in Farrell, K.M., and Keyworth, A.J., eds., Surficial geology and shallow aquifer system of the Little Contentnea Creek watershed, Neuse River basin, North Carolina: Carolina Geological Society Annual Field Trip, November 14-16, 2003, 56 p.

Fetter, C.W., 1994, Applied hydrogeology (3d ed.): Upper Saddle River, NJ, Prentice Hall, Inc., 691 p.

Halford, K.J., and Kuniansky, E.L., 2002, Documentation of spreadsheets for the analysis of aquifer-test and slug-test data: U.S. Geological Survey Open-File Report 02-197, $54 \mathrm{p}$.

Heath, R.C., 1980, Basic elements of ground-water hydrology with reference to conditions in North Carolina: U.S. Geological Survey Open-File Report 80-44, 86 p.
Heath, R.C., 1983, Basic ground-water hydrology: U.S. Geological Survey Water-Supply Paper 2220, 86 p.

HydroSOLVE, Inc., 2003, AQTESOLVTM for Windows, Advanced software for pumping tests and slug tests: Reston, VA, HydroSOLVE, Inc., Aquifer Test Analysis Software.

Jacob, C.E., 1944, Notes on determining permeability by pumping tests under water table conditions: U.S. Geological Survey Open-File Report.

Jacob, C.E., 1950, Flow of ground water, in Rouse, Hunter, Engineering hydraulics: New York, NY, John Wiley and Sons, chap. 5, p. 321-386.

Johnson, A.I., 1962, Specific yield-Compilation of specific yields for various materials: U.S. Geological Survey WaterSupply Paper 1619-U, 25 p.

Kasenow, Michael, 1997, Introduction to aquifer analysis (4th ed.): Highlands Ranch, CO, Water Resource Publications, LLC, $320 \mathrm{p}$.

Kruseman, G.P., and deRidder, N.A., 1990, Analysis and evaluation of pumping test data $(2 \mathrm{~d}$ ed.): Wageningen, The Netherlands, International Institute for Land Reclamation and Improvement, Publication 47, 377 p.

McMahon, Gerard, and Lloyd, O.B., Jr., 1995, Water-quality assessment of the Albemarle-Pamlico drainage basin, North Carolina and Virginia - Environmental setting and waterquality issues: U.S. Geological Survey Open-File Report 95-136, $72 \mathrm{p}$.

Moench, A.F., 1997, Flow to a well of finite diameter in a homogeneous, anisotropic water table aquifer: Water Resources Research, v. 33, no. 6, p. 1397-1407.

Neuman, S.P., 1972, Theory of flow in unconfined aquifers considering delayed response of the water table: Water Resources Research, v. 8, no. 4, p. 1031.

Neuman, S.P., 1974, Effect of partial penetration on flow in unconfined aquifers considering delayed gravity response: Water Resources Research, v. 10, no. 2, p. 303-312.

Neuman, S.P., 1975, Analysis of pumping test data from anisotropic unconfined aquifers considering delayed gravity response: Water Resources Research, v. 11, p. 329-342.

Southeast Regional Climate Center, 2002, Historical climate summaries for North Carolina: accessed in October 2004 at http://www.dnr.state.sc.us/water/climate/sercc/climateinfo/ historical/historical_nc.html

Spruill, T.B., Harned, D.A., Ruhl, P.M., Eimers, J.L., McMahon, Gerard, Smith, K.E., Galeone, D.R., and Woodside, M.D., 1998, Water quality in the AlbemarlePamlico drainage basin, North Carolina and Virginia, 1992-95: U.S. Geological Survey Circular 1157, 36 p. 
Stallman, R.W., 1971, Aquifer-test design, observation, and data analysis: Applications of hydraulics: U.S. Geological Survey Techniques of Water-Resources Investigations, book 3, chap. B1, $26 \mathrm{p}$.

Theis, C.V., 1935, The relation between the lowering of the piezometric surface and the rate and duration of discharge of a well using groundwater storage: Transaction of American Geophysical Union, v. 16, p. 519-524.
Walton, W.C., 1970, Groundwater resource evaluation: New York, NY, McGraw-Hill Book Company, 664 p.

Walton, W.C., 1996, Aquifer test analysis with Windows software: Boca Raton, FL, Lewis Publishing, 301 p.

Winner, M.D., and Coble, R.W., 1996, Hydrogeologic framework of the North Carolina Coastal Plain, Regional Aquifer-System Analysis: U.S. Geological Survey Professional Paper 1404-I, 106 p., 24 pls. 



\section{Appendix 1. Slug-test results for wells at each of the five aquifer-test sites in the Little Contentnea Creek basin, North Carolina, 2002-03}

1-A. Triangle aquifer-test site, Greene County, North Carolina

1-B. Barrett's Farm aquifer-test site, Greene County, North Carolina

1-C. Scuffleton aquifer-test site, Pitt County, North Carolina

1-D. Ballards Crossroads aquifer-test site, Pitt County, North Carolina

1-E. Farmville aquifer-test site, Pitt County, North Carolina

NOTE: The reference for values listed for water level (DTW), top of screen (TOS), and base of aquifer (DTB) in the following datasets is the measuring point at the top of the surface casing. 

Appendix 1A. Slug-test results for wells at the Triangle aquifer-test site in the Little Contentnea Creek basin, Greene County, North Carolina, 2002-03.

WELL ID: TS-1 SLUGIN 1

\begin{tabular}{|cr}
\hline \multicolumn{2}{c}{ INPUT } \\
\hline Construction: & \\
\hline Casing dia. $\left(\mathrm{d}_{\mathrm{c}}\right)$ & 4 Inch \\
Annulus dia. $\left(\mathrm{d}_{\mathrm{w}}\right)$ & 10.25 Inch \\
Screen Length (L) & 15 Feet \\
Depths to: & \\
\hline water level (DTW) & 4.83 Feet \\
top of screen (TOS) & 11.65 Feet \\
Base of Aquifer (DTB) & 26.65 Feet \\
\hline Annular Fill: & \\
across screen -- Fine Sand \\
above screen -- Bentonite \\
Aquifer Material -- Fine Sand
\end{tabular}

Local ID: 1 SLUGIN 1

Date: $4 / 7 / 2004$

Time: $y 0=$

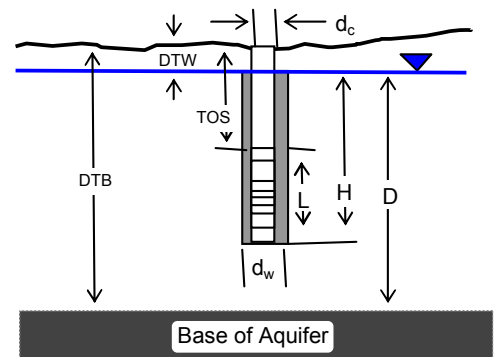

Adjust slope of line to estimate $\mathrm{K}$

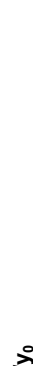

From look-up table using $\mathrm{L} / \mathrm{r}_{\mathrm{w}}$

Fully penetrate $\mathrm{C}=\quad 2.283$

$\ln (\mathrm{Re} / \mathrm{rw})=\quad 2.901$

$\mathrm{Re}=\quad 7.77$ Feet

Slope $=0.004902 \log _{10} / \mathrm{sec}$

$t_{90 \%}$ recovery $=$ $204 \mathrm{sec}$

Input is consistent.

\section{Feet/Day}

\begin{tabular}{rr}
\hline $\mathrm{K}=$ & 3 Feet/Day \\
\hline
\end{tabular}

REMARKS

Triangle Site, well 1, slug in 1

Assumed annulus 10.25

mw 2.15'

assumed water level as beginning water level from data

assumed slug $5^{\prime}$

$\begin{array}{ccc} & \text { Reduced Data } & \\ & \text { Time, } & \text { Water } \\ \text { Entry } & \text { Hr:Min:Sec } & \text { Level } \\ 1 & 10: 49: 55.0 & 3.80 \\ 2 & 10: 49: 58.0 & 3.85 \\ 3 & 10: 50: 01.0 & 3.90 \\ 4 & 10: 50: 04.0 & 3.95 \\ 5 & 10: 50: 07.0 & 3.99 \\ 6 & 10: 50: 10.0 & 4.04 \\ 7 & 10: 50: 13.0 & 4.07 \\ 8 & 10: 50: 16.0 & 4.10 \\ 9 & 10: 50: 19.0 & 4.14 \\ 10 & 10: 50: 22.0 & 4.17 \\ 11 & 10: 50: 25.0 & 4.20 \\ 12 & 10: 50: 28.0 & 4.23 \\ 13 & 10: 50: 31.0 & 4.26 \\ 14 & 10: 50: 34.0 & 4.29 \\ 15 & 10: 50: 37.0 & 4.31 \\ 16 & 10: 50: 39.0 & 4.32 \\ 17 & 10: 50: 42.0 & 4.35 \\ 18 & 10: 50: 45.0 & 4.37 \\ 19 & 10: 50: 48.0 & 4.39 \\ 20 & 10: 50: 51.0 & 4.41 \\ 21 & 10: 50: 54.0 & 4.43 \\ 22 & 10: 50: 58.0 & 4.45 \\ 23 & 10: 51: 01.0 & 4.46 \\ 24 & 10: 51: 05.0 & 4.47 \\ 25 & 10: 51: 09.0 & 4.49 \\ 26 & 10: 51: 13.0 & 4.51 \\ 27 & 10: 51: 18.0 & 4.53 \\ 28 & 10: 51: 23.0 & 4.55 \\ 29 & 10: 51: 28.0 & 4.56 \\ 30 & 10: 51: 33.0 & 4.58 \\ 31 & 10: 51: 38.0 & 4.60 \\ 32 & 10: 51: 44.0 & 4.61 \\ 33 & 10: 51: 51.0 & 4.63 \\ 34 & 10: 51: 57.0 & 4.65 \\ 35 & 10: 52: 05.0 & 4.66 \\ 36 & 10: 52: 12.0 & 4.66 \\ 37 & 10: 52: 20.0 & 4.68 \\ 38 & 10: 52: 28.0 & 4.69 \\ 39 & 10: 52: 37.0 & 4.71 \\ 40 & 10: 52: 47.0 & 4.72 \\ 41 & 10: 52: 57.0 & 4.73 \\ 43 & 10: 53: 07.0 & 4.74 \\ 45 & 10: 53: 19.0 & 4.75 \\ & 10: 53: 31.0 & 4.76 \\ 10: 53: 43.0 & 4.76\end{array}$


Appendix 1A. Slug-test results for wells at the Triangle aquifer-test site in the Little Contentnea Creek basin, Greene County, North Carolina, 2002-03. - Continued

WELL ID: TS-1 SLUGOUT 1

\begin{tabular}{|c|c|}
\hline & NPUT \\
\hline \multicolumn{2}{|l|}{ Construction: } \\
\hline Casing dia. $\left(\mathrm{d}_{\mathrm{c}}\right)$ & 4 Inch \\
\hline Annulus dia. $\left(\mathrm{d}_{\mathrm{w}}\right)$ & 10.25 Inch \\
\hline Screen Length (L) & 15 Feet \\
\hline \multicolumn{2}{|l|}{ Depths to: } \\
\hline water level (DTW) & 4.83 Feet \\
\hline top of screen (TOS) & 11.65 Feet \\
\hline Base of Aquifer (DTB) & 26.65 Feet \\
\hline \multicolumn{2}{|c|}{ Annular Fill: } \\
\hline \multicolumn{2}{|c|}{$\begin{array}{c}\text { across screen -- Fine Sand } \\
\text { above screen -- Bentonite }\end{array}$} \\
\hline \multicolumn{2}{|c|}{ Aquifer Material -- Fine Sand } \\
\hline \multicolumn{2}{|c|}{ COMPUTED } \\
\hline $\mathrm{L}_{\text {wetted }}$ & 15 Feet \\
\hline$D=$ & 21.82 Feet \\
\hline $\mathrm{H}=$ & 21.82 Feet \\
\hline $\mathrm{L} / \mathrm{r}_{\mathrm{w}}=$ & 35.12 \\
\hline $\mathrm{y}_{0-D I S P L A C E M E N T}=$ & 1.13 Feet \\
\hline $\mathrm{y}_{0-\mathrm{SLUG}}=$ & 1.95 Feet \\
\hline \multicolumn{2}{|c|}{ From look-up table using $L / r_{w}$} \\
\hline Fully penetrate $\mathrm{C}=$ & 2.283 \\
\hline $\ln (\operatorname{Re} / r w)=$ & 2.901 \\
\hline $\mathrm{Re}=$ & 7.77 Feet \\
\hline Slope $=$ & $0.006673 \log _{10} / \mathrm{sec}$ \\
\hline$t_{90 \%}$ recovery $=$ & $150 \mathrm{sec}$ \\
\hline \multicolumn{2}{|l|}{ Input is consistent. } \\
\hline $\mathrm{K}=$ & 4 Feet/Day \\
\hline
\end{tabular}

REMARKS:

Triangle Site, well 1, slug out 1

Assumed annulus 10.25

mw 2.15'

assumed water level as beginning water level from data

assumed slug $5^{\prime}$
Local ID: TS-1 SLUGOUT 1

Date: $4 / 7 / 2004$

Time: $y 0=$

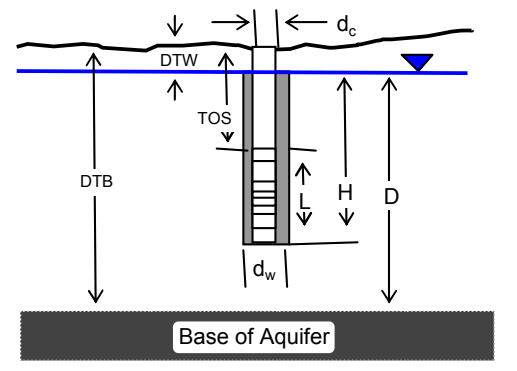

Adjust slope of line to estimate K

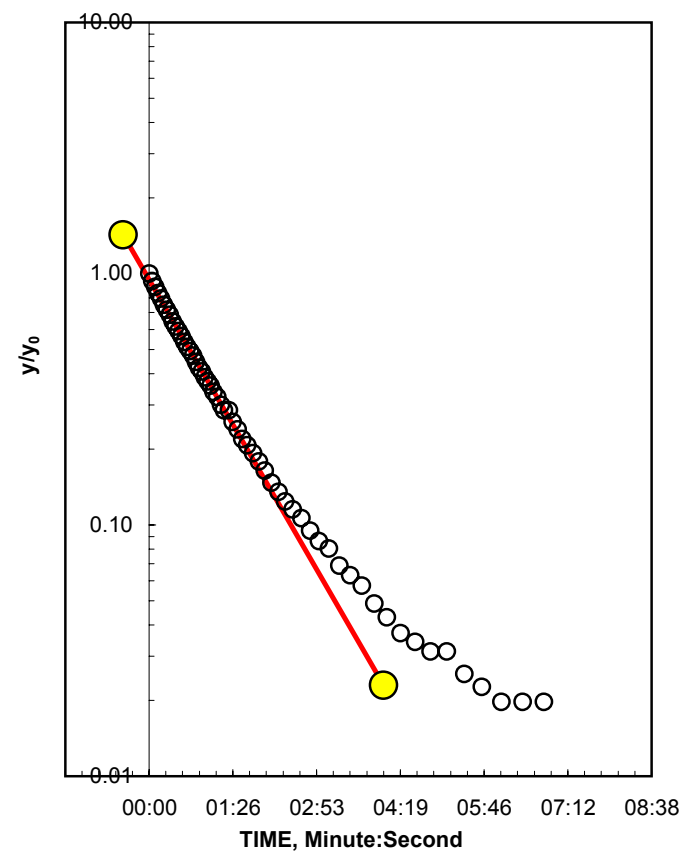

Bouwer and Rice (1976) analysis of slug test

$\begin{array}{ccc} & \text { Reduced Data } & \\ & \text { Time, } & \text { Water } \\ \text { Entry } & \text { Hr:Min:Sec } & \text { Level } \\ 1 & 11: 07: 51.0 & 5.96 \\ 2 & 11: 07: 54.0 & 5.89 \\ 3 & 11: 07: 57.0 & 5.83 \\ 4 & 11: 08: 00.0 & 5.78 \\ 5 & 11: 08: 03.0 & 5.73 \\ 6 & 11: 08: 06.0 & 5.68 \\ 7 & 11: 08: 09.0 & 5.64 \\ 8 & 11: 08: 12.0 & 5.61 \\ 9 & 11: 08: 15.0 & 5.56 \\ 10 & 11: 08: 18.0 & 5.53 \\ 11 & 11: 08: 21.0 & 5.50 \\ 12 & 11: 08: 24.0 & 5.47 \\ 13 & 11: 08: 27.0 & 5.44 \\ 14 & 11: 08: 30.0 & 5.41 \\ 15 & 11: 08: 33.0 & 5.39 \\ 16 & 11: 08: 36.0 & 5.36 \\ 17 & 11: 08: 39.0 & 5.33 \\ 18 & 11: 08: 42.0 & 5.31 \\ 19 & 11: 08: 45.0 & 5.29 \\ 20 & 11: 08: 48.0 & 5.27 \\ 21 & 11: 08: 51.0 & 5.25 \\ 22 & 11: 08: 54.0 & 5.24 \\ 23 & 11: 08: 57.0 & 5.21 \\ 24 & 11: 09: 01.0 & 5.20 \\ 25 & 11: 09: 05.0 & 5.17 \\ 26 & 11: 09: 08.0 & 5.15 \\ 27 & 11: 09: 13.0 & 5.15 \\ 28 & 11: 09: 17.0 & 5.12 \\ 29 & 11: 09: 22.0 & 5.10 \\ 30 & 11: 09: 27.0 & 5.08 \\ 31 & 11: 09: 32.0 & 5.07 \\ 32 & 11: 09: 38.0 & 5.05 \\ 33 & 11: 09: 44.0 & 5.03 \\ 34 & 11: 09: 50.0 & 5.02 \\ 35 & 11: 09: 57.0 & 5.00 \\ 36 & 11: 10: 04.0 & 4.98 \\ 37 & 11: 10: 11.0 & 4.97 \\ 38 & 11: 10: 19.0 & 4.96 \\ 39 & 11: 10: 28.0 & 4.95 \\ 40 & 11: 10: 37.0 & 4.94 \\ 43 & 11: 10: 46.0 & 4.93 \\ 43 & 11: 10: 56.0 & 4.92 \\ & 11: 11: 07.0 & 4.91 \\ 11: 11: 18.0 & 4.90 \\ 13 & & 4.90\end{array}$


Appendix 1A. Slug-test results for wells at the Triangle aquifer-test site in the Little Contentnea Creek basin, Greene County, North Carolina, 2002-03. - Continued

WELL ID: TS-1A SLUGIN 1

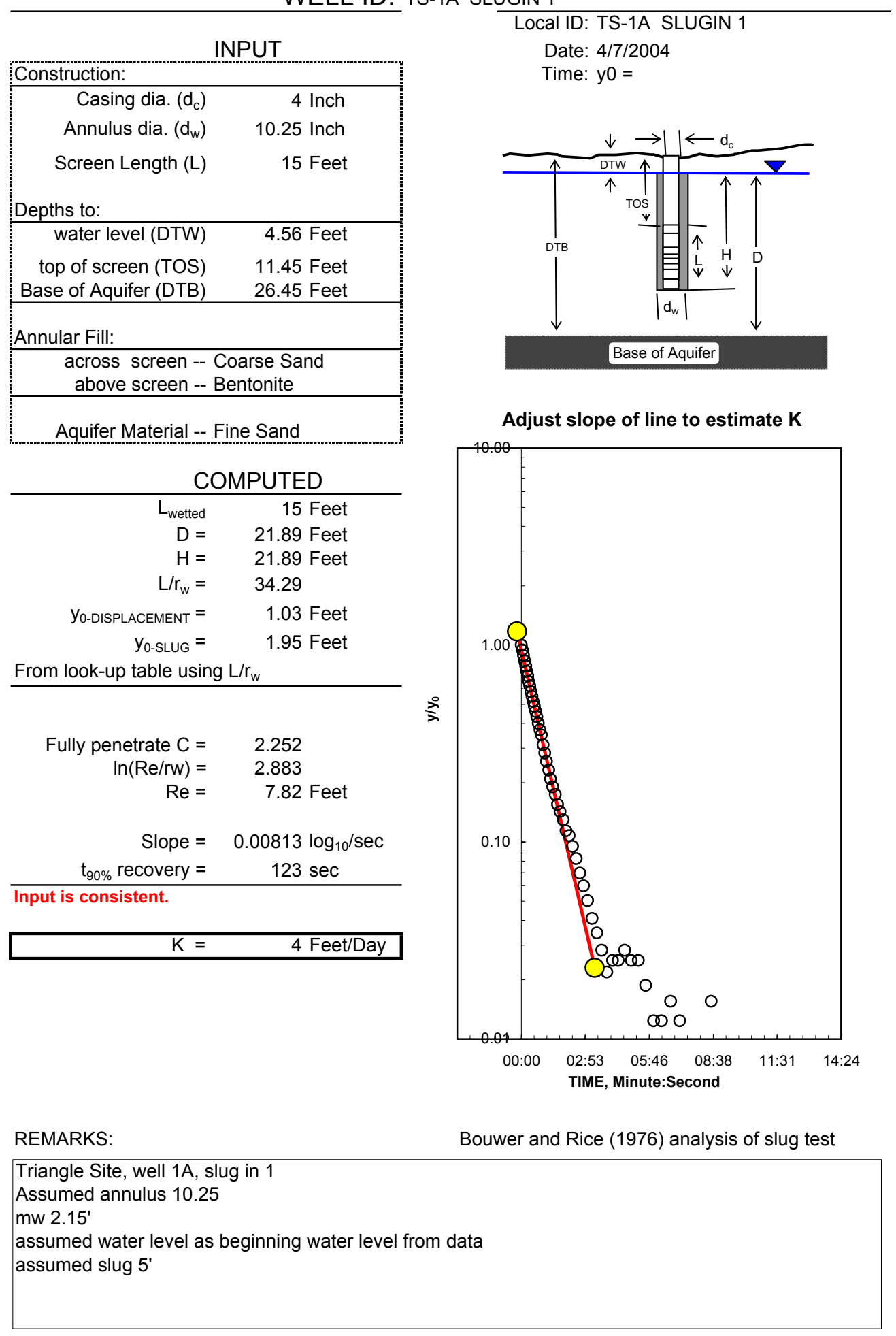

\begin{tabular}{ccc} 
& Reduced Data & \\
& Time, & Water \\
Entry & Hr:Min:Sec & Level \\
1 & $15: 09: 04.0$ & 3.53 \\
2 & $15: 09: 07.0$ & 3.59 \\
3 & $15: 09: 10.0$ & 3.65 \\
4 & $15: 09: 13.0$ & 3.70 \\
5 & $15: 09: 16.0$ & 3.75 \\
6 & $15: 09: 18.0$ & 3.80 \\
7 & $15: 09: 21.0$ & 3.84 \\
8 & $15: 09: 24.0$ & 3.88 \\
9 & $15: 09: 27.0$ & 3.92 \\
10 & $15: 09: 30.0$ & 3.96 \\
11 & $15: 09: 33.0$ & 3.99 \\
12 & $15: 09: 36.0$ & 4.03 \\
13 & $15: 09: 39.0$ & 4.06 \\
14 & $15: 09: 43.0$ & 4.08 \\
15 & $15: 09: 46.0$ & 4.11 \\
16 & $15: 09: 50.0$ & 4.15 \\
17 & $15: 09: 54.0$ & 4.18 \\
18 & $15: 09: 58.0$ & 4.20 \\
19 & $15: 10: 03.0$ & 4.24 \\
20 & $15: 10: 07.0$ & 4.27 \\
21 & $15: 10: 12.0$ & 4.29 \\
22 & $15: 10: 18.0$ & 4.32 \\
23 & $15: 10: 23.0$ & 4.34 \\
24 & $15: 10: 29.0$ & 4.36 \\
25 & $15: 10: 36.0$ & 4.38 \\
26 & $15: 10: 42.0$ & 4.40 \\
27 & $15: 10: 49.0$ & 4.41 \\
28 & $15: 10: 57.0$ & 4.43 \\
29 & $15: 11: 05.0$ & 4.44 \\
30 & $15: 11: 13.0$ & 4.45 \\
31 & $15: 11: 22.0$ & 4.46 \\
32 & $15: 11: 32.0$ & 4.48 \\
33 & $15: 11: 42.0$ & 4.49 \\
34 & $15: 11: 52.0$ & 4.50 \\
35 & $15: 12: 03.0$ & 4.51 \\
36 & $15: 12: 15.0$ & 4.52 \\
37 & $15: 12: 28.0$ & 4.52 \\
38 & $15: 12: 41.0$ & 4.53 \\
39 & $15: 12: 55.0$ & 4.54 \\
40 & $15: 13: 10.0$ & 4.53 \\
41 & $15: 13: 26.0$ & 4.53 \\
$15: 13: 43.0$ & 4.53 \\
\hline 2 & $15: 14: 01.0$ & 4.53 \\
\hline $3: 14: 40.0$ & 4.53 \\
\hline 3 & & 4.54
\end{tabular}


Appendix 1A. Slug-test results for wells at the Triangle aquifer-test site in the Little Contentnea Creek basin, Greene County, North Carolina, 2002-03. - Continued

WELL ID: TS-1A SLUGOUT 1

\begin{tabular}{|c|c|}
\hline & NPUT \\
\hline \multicolumn{2}{|l|}{ Construction: } \\
\hline Casing dia. $\left(\mathrm{d}_{\mathrm{c}}\right)$ & 4 Inch \\
\hline Annulus dia. $\left(d_{w}\right)$ & 10.25 Inch \\
\hline Screen Length $(\mathrm{L})$ & 15 Feet \\
\hline \multicolumn{2}{|l|}{ Depths to: } \\
\hline water level (DTW) & 4.56 Feet \\
\hline top of screen (TOS) & 11.45 Feet \\
\hline Base of Aquifer (DTB) & 26.45 Feet \\
\hline \multicolumn{2}{|c|}{ Annular Fill: } \\
\hline \multicolumn{2}{|c|}{$\begin{array}{c}\text { across screen -- Coarse Sand } \\
\text { above screen -- Bentonite }\end{array}$} \\
\hline \multicolumn{2}{|c|}{ Aquifer Material -- Fine Sand } \\
\hline \multicolumn{2}{|c|}{ COMPUTED } \\
\hline $\mathrm{L}_{\text {wetted }}$ & 15 Feet \\
\hline$D=$ & 21.89 Feet \\
\hline$H=$ & 21.89 Feet \\
\hline $\mathrm{L} / \mathrm{r}_{\mathrm{w}}=$ & 35.12 \\
\hline $\mathrm{y}_{0 \text {-DISPLACEMENT }}=$ & 1.10 Feet \\
\hline $\mathrm{y}_{0-S L U G}=$ & 1.95 Feet \\
\hline \multicolumn{2}{|c|}{ From look-up table using $\mathrm{L} / \mathrm{r}_{\mathrm{w}}$} \\
\hline Fully penetrate $C=$ & 2.283 \\
\hline $\ln (\operatorname{Re} / r w)=$ & 2.903 \\
\hline $\operatorname{Re}=$ & 7.79 Feet \\
\hline Slope $=$ & $0.007946 \log _{10} / \mathrm{sec}$ \\
\hline$t_{90 \%}$ recovery $=$ & $126 \mathrm{sec}$ \\
\hline \multicolumn{2}{|l|}{ Input is consistent. } \\
\hline $\mathrm{K}=$ & 4 Feet/Day \\
\hline
\end{tabular}

REMARKS:

Triangle Site, well $1 \mathrm{~A}$, slug out 1

Assumed annulus 10.25

mw 2.15'

assumed water level as beginning water level from data

assumed slug $5^{\prime}$

\section{Local ID: TS-1A SLUGOUT 1}

Date: $4 / 7 / 2004$

Time: $\mathrm{y} 0=$
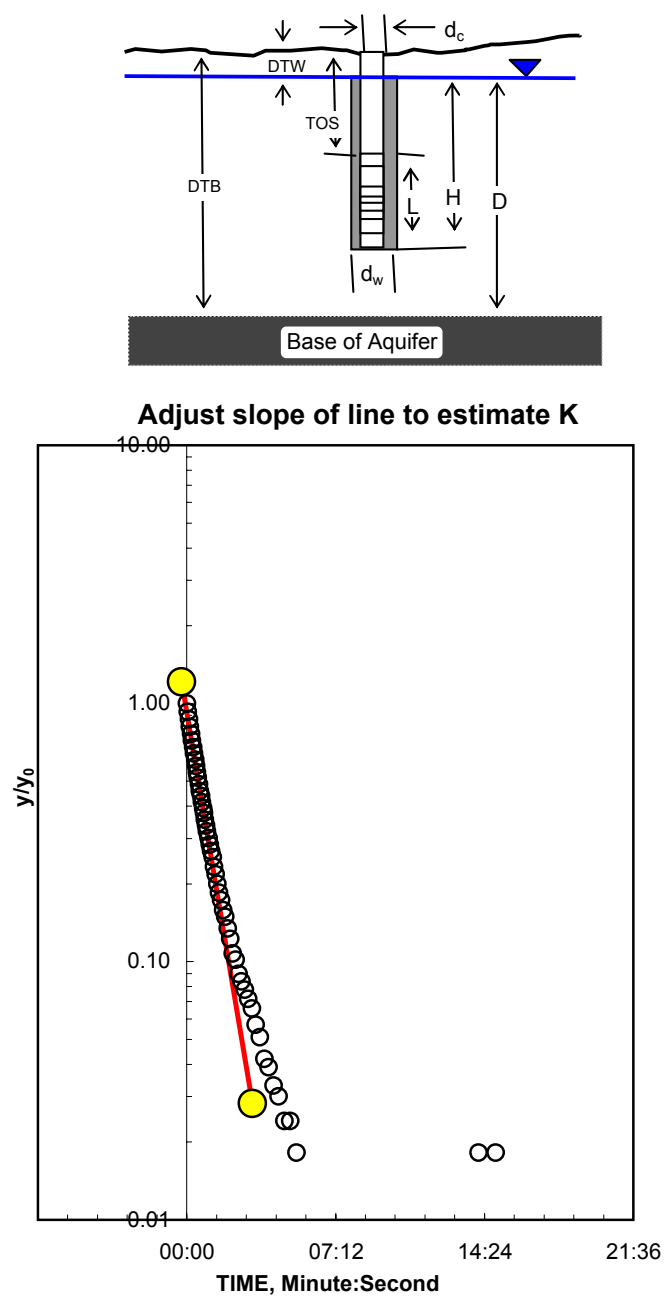

Bouwer and Rice (1976) analysis of slug test

\begin{tabular}{ccc} 
& Reduced Data & \\
& Time, & Water \\
Entry & Hr:Min:Sec & Level \\
1 & $15: 25: 48.0$ & 5.66 \\
2 & $15: 25: 51.0$ & 5.58 \\
3 & $15: 25: 54.0$ & 5.52 \\
4 & $15: 25: 57.0$ & 5.46 \\
5 & $15: 26: 00.0$ & 5.40 \\
6 & $15: 26: 03.0$ & 5.35 \\
7 & $15: 26: 06.0$ & 5.31 \\
8 & $15: 26: 09.0$ & 5.27 \\
9 & $15: 26: 12.0$ & 5.23 \\
10 & $15: 26: 15.0$ & 5.19 \\
11 & $15: 26: 17.0$ & 5.16 \\
12 & $15: 26: 20.0$ & 5.13 \\
13 & $15: 26: 23.0$ & 5.10 \\
14 & $15: 26: 26.0$ & 5.07 \\
15 & $15: 26: 29.0$ & 5.04 \\
16 & $15: 26: 32.0$ & 5.02 \\
17 & $15: 26: 35.0$ & 4.99 \\
18 & $15: 26: 38.0$ & 4.97 \\
19 & $15: 26: 41.0$ & 4.95 \\
20 & $15: 26: 44.0$ & 4.93 \\
21 & $15: 26: 47.0$ & 4.91 \\
22 & $15: 26: 51.0$ & 4.89 \\
23 & $15: 26: 55.0$ & 4.87 \\
24 & $15: 26: 59.0$ & 4.86 \\
25 & $15: 27: 03.0$ & 4.84 \\
26 & $15: 27: 07.0$ & 4.82 \\
27 & $15: 27: 12.0$ & 4.80 \\
28 & $15: 27: 17.0$ & 4.78 \\
29 & $15: 27: 22.0$ & 4.76 \\
30 & $15: 27: 28.0$ & 4.75 \\
31 & $15: 27: 34.0$ & 4.73 \\
33 & $15: 29: 20.0$ & 4.62 \\
32 & $15: 27: 40.0$ & 4.72 \\
33 & $15: 27: 47.0$ & 4.71 \\
34 & $15: 27: 54.0$ & 4.69 \\
35 & $15: 28: 02.0$ & 4.68 \\
36 & $15: 28: 10.0$ & 4.67 \\
37 & $15: 28: 18.0$ & 4.66 \\
38 & $15: 28: 27.0$ & 4.65 \\
39 & $15: 28: 36.0$ & 4.65 \\
40 & $15: 28: 46.0$ & 4.64 \\
& $15: 28: 57.0$ & 4.63 \\
43 & & 4.61 \\
\hline 3 & & 4.60
\end{tabular}


Appendix 1A. Slug-test results for wells at the Triangle aquifer-test site in the Little Contentnea Creek basin, Greene County, North Carolina, 2002-03. - Continued

WELL ID: TS-2 SLUGIN 2

\begin{tabular}{|c|c|}
\hline & NPUT \\
\hline \multicolumn{2}{|l|}{ Construction: } \\
\hline Casing dia. $\left(\mathrm{d}_{\mathrm{c}}\right)$ & 2 Inch \\
\hline Annulus dia. $\left(d_{w}\right)$ & 8.25 Inch \\
\hline Screen Length (L) & 15 Feet \\
\hline \multicolumn{2}{|l|}{ Depths to: } \\
\hline water level (DTW) & 3.4 Feet \\
\hline top of screen (TOS) & 9.7 Feet \\
\hline Base of Aquifer (DTB) & 24.7 Feet \\
\hline \multicolumn{2}{|c|}{ Annular Fill: } \\
\hline \multicolumn{2}{|c|}{$\begin{array}{c}\text { across screen -- Fine Sand } \\
\text { above screen -- Bentonite }\end{array}$} \\
\hline \multicolumn{2}{|c|}{ Aquifer Material -- Fine Sand } \\
\hline \multicolumn{2}{|c|}{ COMPUTED } \\
\hline $\mathrm{L}_{\text {wetted }}$ & 15 Feet \\
\hline$D=$ & 21.3 Feet \\
\hline $\mathrm{H}=$ & 21.3 Feet \\
\hline $\mathrm{L} / \mathrm{r}_{\mathrm{w}}=$ & 43.64 \\
\hline $\mathrm{y}_{0 \text {-DISPLACEMENT }}=$ & 0.93 Feet \\
\hline $\mathrm{y}_{0-\mathrm{SLUG}}=$ & 1.25 Feet \\
\hline \multicolumn{2}{|c|}{ From look-up table using $\mathrm{L} / \mathrm{r}_{\mathrm{w}}$} \\
\hline Fully penetrate $\mathrm{C}=$ & 2.563 \\
\hline $\ln (\mathrm{Re} / \mathrm{rw})=$ & 3.074 \\
\hline $\mathrm{Re}=$ & 7.44 Feet \\
\hline Slope $=$ & $0.032077 \log _{10} / \mathrm{sec}$ \\
\hline$t_{90 \%}$ recovery $=$ & $31 \mathrm{sec}$ \\
\hline \multicolumn{2}{|l|}{ Input is consistent. } \\
\hline $\mathrm{K}=$ & 5 Feet/Day \\
\hline
\end{tabular}

REMARKS:

Triangle Site, well 2, slug in 2

Assumed annulus 8.25

mw $0.7^{\prime}$

assumed water level as beginning water level from data

assumed slug $5^{\prime}$
Local ID: 2 SLUGIN 2

Date: $4 / 7 / 2004$

Time: $y 0=$
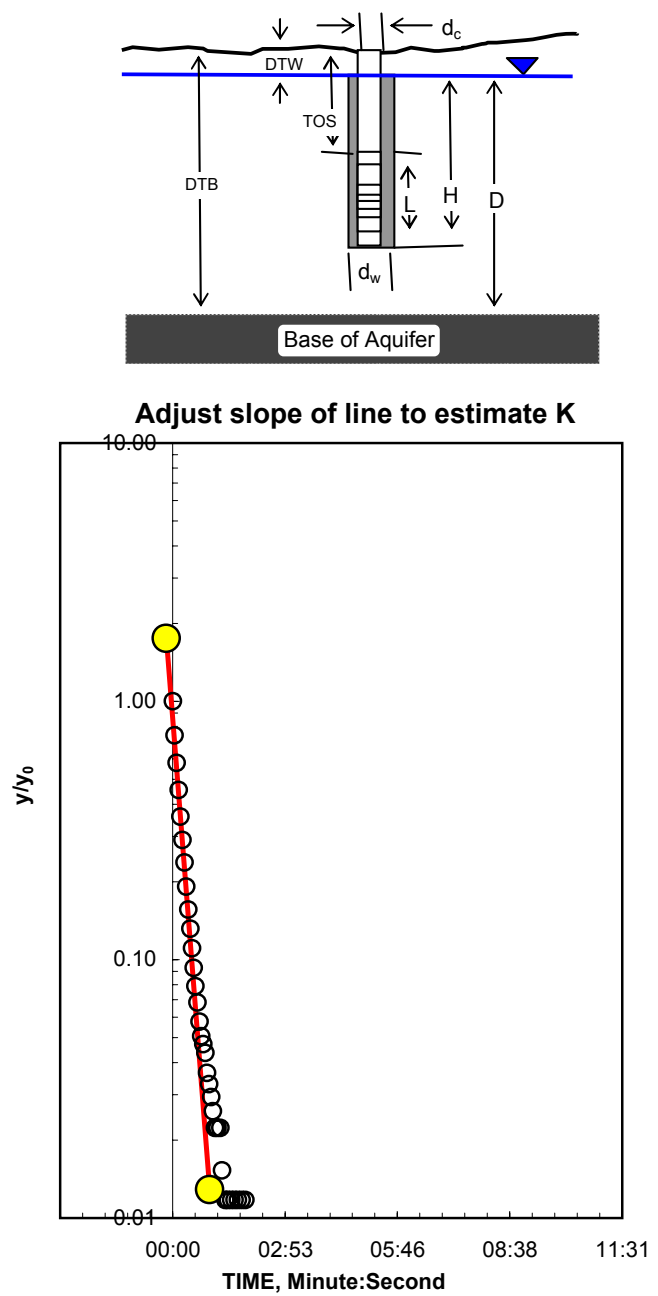

Bouwer and Rice (1976) analysis of slug test

\begin{tabular}{ccc} 
& Reduced Data & \\
& Time, & Water \\
Entry & Hr:Min:Sec & Level \\
1 & $12: 21: 48.0$ & 2.47 \\
2 & $12: 21: 51.0$ & 2.71 \\
3 & $12: 21: 54.0$ & 2.86 \\
4 & $12: 21: 57.0$ & 2.98 \\
5 & $12: 22: 00.0$ & 3.07 \\
6 & $12: 22: 03.0$ & 3.13 \\
7 & $12: 22: 06.0$ & 3.18 \\
8 & $12: 22: 09.0$ & 3.22 \\
9 & $12: 22: 12.0$ & 3.25 \\
10 & $12: 22: 15.0$ & 3.28 \\
11 & $12: 22: 18.0$ & 3.30 \\
12 & $12: 22: 20.0$ & 3.31 \\
13 & $12: 22: 23.0$ & 3.33 \\
14 & $12: 22: 26.0$ & 3.34 \\
15 & $12: 22: 29.0$ & 3.35 \\
16 & $12: 22: 32.0$ & 3.35 \\
17 & $12: 22: 35.0$ & 3.36 \\
18 & $12: 22: 38.0$ & 3.36 \\
19 & $12: 22: 41.0$ & 3.37 \\
20 & $12: 22: 44.0$ & 3.37 \\
21 & $12: 22: 47.0$ & 3.37 \\
22 & $12: 22: 50.0$ & 3.38 \\
23 & $12: 22: 53.0$ & 3.38 \\
24 & $12: 22: 57.0$ & 3.38 \\
25 & $12: 23: 01.0$ & 3.38 \\
26 & $12: 23: 04.0$ & 3.39 \\
27 & $12: 23: 09.0$ & 3.39 \\
28 & $12: 23: 13.0$ & 3.39 \\
29 & $12: 23: 18.0$ & 3.39 \\
30 & $12: 23: 23.0$ & 3.39 \\
31 & $12: 23: 28.0$ & 3.39 \\
32 & $12: 23: 34.0$ & 3.39 \\
33 & $12: 23: 40.0$ & 3.39 \\
34 & $12: 23: 46.0$ & 3.39 \\
35 & $12: 23: 53.0$ & 3.39 \\
36 & $12: 24: 00.0$ & 3.40 \\
37 & $12: 24: 07.0$ & 3.40 \\
38 & $12: 24: 15.0$ & 3.40 \\
39 & $12: 24: 24.0$ & 3.40 \\
40 & $12: 24: 33.0$ & 3.40 \\
45 & $12: 24: 42.0$ & 3.40 \\
& $12: 24: 52.0$ & 3.40 \\
& $12: 25: 03.0$ & 3.40 \\
$12: 25: 14.0$ & 3.40 \\
\hline 3 & $12: 25: 26.0$ & 3.40
\end{tabular}


Appendix 1A. Slug-test results for wells at the Triangle aquifer-test site in the Little Contentnea Creek basin, Greene County, North Carolina, 2002-03. - Continued

WELL ID: TS-2 SLUGOUT 1

\begin{tabular}{|c|c|}
\hline \multicolumn{2}{|c|}{ INPUT } \\
\hline \multicolumn{2}{|l|}{ Construction: } \\
\hline Casing dia. $\left(\mathrm{d}_{\mathrm{c}}\right)$ & 2 Inch \\
\hline Annulus dia. $\left(\mathrm{d}_{\mathrm{w}}\right)$ & 8.25 Inch \\
\hline Screen Length (L) & 15 Feet \\
\hline \multicolumn{2}{|l|}{ Depths to: } \\
\hline water level (DTW) & 3.4 Feet \\
\hline top of screen (TOS) & 9.7 Feet \\
\hline Base of Aquifer (DTB) & 24.7 Feet \\
\hline \multicolumn{2}{|c|}{ Annular Fill: } \\
\hline \multicolumn{2}{|c|}{$\begin{array}{c}\text { across screen -- Fine Sand } \\
\text { above screen -- Bentonite }\end{array}$} \\
\hline \multicolumn{2}{|c|}{ Aquifer Material -- Fine Sand } \\
\hline \multicolumn{2}{|c|}{ COMPUTED } \\
\hline $\mathrm{L}_{\text {wetted }}$ & 15 Feet \\
\hline$D=$ & 21.3 Feet \\
\hline $\mathrm{H}=$ & 21.3 Feet \\
\hline $\mathrm{L} / \mathrm{r}_{\mathrm{w}}=$ & 43.64 \\
\hline $\mathrm{y}_{0-\text { DISPLACEMENT }}=$ & 0.95 Feet \\
\hline $\mathrm{y}_{0-\mathrm{SLUG}}=$ & 0.75 Feet \\
\hline \multicolumn{2}{|c|}{ From look-up table using $\mathrm{L} / \mathrm{r}_{\mathrm{w}}$} \\
\hline Fully penetrate $\mathrm{C}=$ & 2.563 \\
\hline $\ln (\operatorname{Re} / r w)=$ & 3.074 \\
\hline $\operatorname{Re}=$ & 7.44 Feet \\
\hline Slope $=$ & $0.030734 \log _{10} / \mathrm{sec}$ \\
\hline$t_{90 \%}$ recovery $=$ & $33 \mathrm{sec}$ \\
\hline \multicolumn{2}{|l|}{ Input is consistent. } \\
\hline $\mathrm{K}=$ & 4 Feet/Day \\
\hline
\end{tabular}

REMARKS:

Triangle Site, well 2, slug out 1

Assumed annulus 8.25

mw- 0.7'

assumed water level as beginning water level from data

assumed slug $3^{\prime}$
Local ID: TS-2 SLUGOUT 1

Date: $4 / 7 / 2004$

Time: $\mathrm{y} 0=$
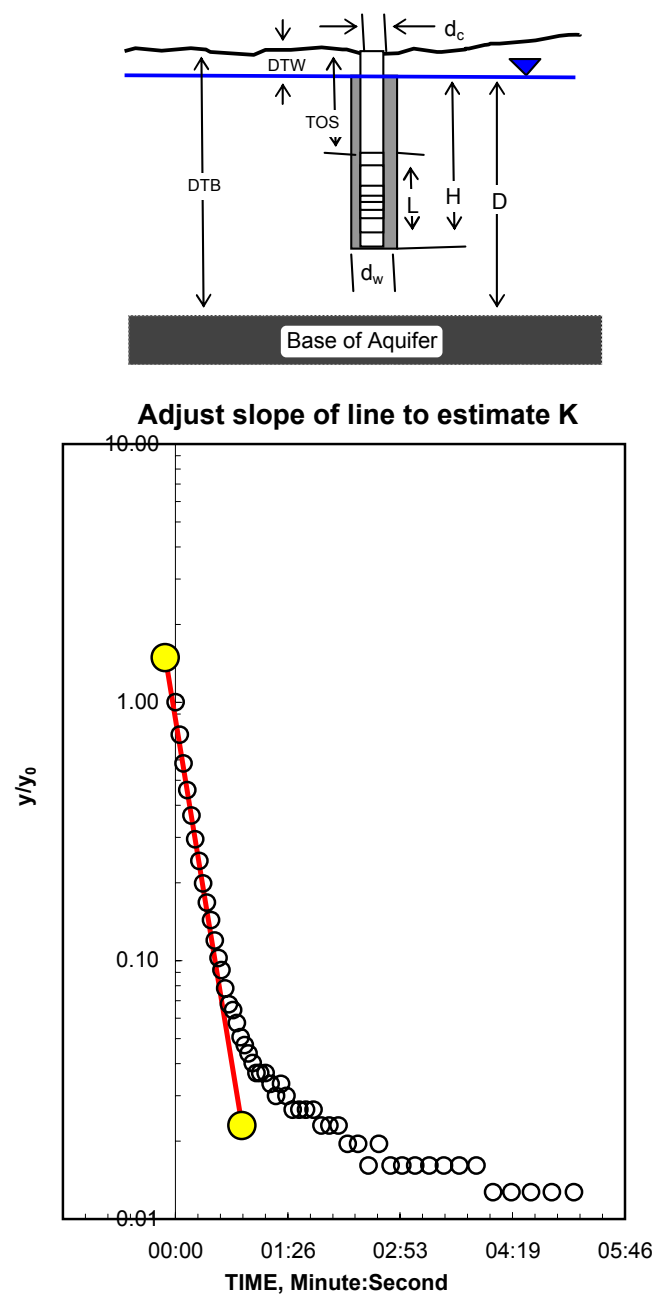

Bouwer and Rice (1976) analysis of slug test

\begin{tabular}{ccc} 
& Reduced Data & \\
& Time, & Water \\
Entry & Hr:Min:Sec & Level \\
1 & $12: 11: 06.0$ & 4.35 \\
2 & $12: 11: 09.0$ & 4.11 \\
3 & $12: 11: 12.0$ & 3.95 \\
4 & $12: 11: 15.0$ & 3.84 \\
5 & $12: 11: 18.0$ & 3.75 \\
6 & $12: 11: 21.0$ & 3.68 \\
7 & $12: 11: 24.0$ & 3.63 \\
8 & $12: 11: 27.0$ & 3.59 \\
9 & $12: 11: 30.0$ & 3.56 \\
10 & $12: 11: 33.0$ & 3.54 \\
11 & $12: 11: 36.0$ & 3.51 \\
12 & $12: 11: 39.0$ & 3.50 \\
13 & $12: 11: 41.0$ & 3.49 \\
14 & $12: 11: 44.0$ & 3.47 \\
15 & $12: 11: 47.0$ & 3.46 \\
16 & $12: 11: 50.0$ & 3.46 \\
17 & $12: 11: 53.0$ & 3.45 \\
18 & $12: 11: 56.0$ & 3.45 \\
19 & $12: 11: 59.0$ & 3.44 \\
20 & $12: 12: 02.0$ & 3.44 \\
21 & $12: 12: 05.0$ & 3.44 \\
22 & $12: 12: 08.0$ & 3.44 \\
23 & $12: 12: 11.0$ & 3.44 \\
24 & $12: 12: 15.0$ & 3.44 \\
25 & $12: 12: 19.0$ & 3.43 \\
26 & $12: 12: 23.0$ & 3.43 \\
27 & $12: 12: 27.0$ & 3.43 \\
28 & $12: 12: 31.0$ & 3.43 \\
29 & $12: 12: 36.0$ & 3.43 \\
30 & $12: 12: 41.0$ & 3.43 \\
31 & $12: 12: 46.0$ & 3.43 \\
32 & $12: 12: 52.0$ & 3.43 \\
33 & $12: 12: 58.0$ & 3.42 \\
34 & $12: 13: 04.0$ & 3.42 \\
35 & $12: 13: 11.0$ & 3.42 \\
36 & $12: 13: 18.0$ & 3.42 \\
37 & $12: 13: 26.0$ & 3.42 \\
38 & $12: 13: 34.0$ & 3.42 \\
39 & $12: 13: 42.0$ & 3.42 \\
40 & $12: 13: 51.0$ & 3.42 \\
41 & $12: 14: 00.0$ & 3.42 \\
42 & $12: 14: 10.0$ & 3.42 \\
45 & $12: 14: 21.0$ & 3.42 \\
& $12: 14: 32.0$ & 3.42 \\
$12: 14: 44.0$ & 3.42 \\
\hline 3 & &
\end{tabular}


Appendix 1A. Slug-test results for wells at the Triangle aquifer-test site in the Little Contentnea Creek basin, Greene County, North Carolina, 2002-03. - Continued

WELL ID: TS-3 SLUGIN 1

\begin{tabular}{|c|c|}
\hline & INPUT \\
\hline \multicolumn{2}{|l|}{ Construction: } \\
\hline Casing dia. $\left(\mathrm{d}_{\mathrm{c}}\right)$ & 2 Inch \\
\hline Annulus dia. $\left(\mathrm{d}_{\mathrm{w}}\right)$ & 8.25 Inch \\
\hline Screen Length (L) & 15 Feet \\
\hline \multicolumn{2}{|l|}{ Depths to: } \\
\hline water level (DTW) & 3.56 Feet \\
\hline top of screen (TOS) & 9.85 Feet \\
\hline Base of Aquifer (DTB) & 24.85 Feet \\
\hline \multicolumn{2}{|c|}{ Annular Fill: } \\
\hline \multicolumn{2}{|c|}{$\begin{array}{c}\text { across screen -- Fine Sand } \\
\text { above screen -- Bentonite }\end{array}$} \\
\hline \multicolumn{2}{|c|}{ Aquifer Material -- Fine Sand } \\
\hline \multicolumn{2}{|c|}{ COMPUTED } \\
\hline $\mathrm{L}_{\text {wetted }}$ & 15 Feet \\
\hline$D=$ & 21.29 Feet \\
\hline$H=$ & 21.29 Feet \\
\hline $\mathrm{L} / \mathrm{r}_{\mathrm{w}}=$ & 43.64 \\
\hline $\mathrm{y}_{0 \text {-DISPLACEMENT }}=$ & 1.14 Feet \\
\hline $\mathrm{y}_{0-\mathrm{SLUG}}=$ & 1.25 Feet \\
\hline \multicolumn{2}{|c|}{ From look-up table using $\mathrm{L} / \mathrm{r}_{\mathrm{w}}$} \\
\hline Fully penetrate $\mathrm{C}=$ & 2.563 \\
\hline $\ln (\mathrm{Re} / \mathrm{rw})=$ & 3.074 \\
\hline $\operatorname{Re}=$ & 7.43 Feet \\
\hline Slope $=$ & $0.072953 \log _{10} / \mathrm{sec}$ \\
\hline$t_{90 \%}$ recovery $=$ & $14 \mathrm{sec}$ \\
\hline \multicolumn{2}{|l|}{ Input is consistent. } \\
\hline $\mathrm{K}=$ & 10 Feet/Day \\
\hline
\end{tabular}

REMARKS:

Triangle Site, well 3, slug in 1

Assumed annulus 8.25

$\mathrm{mw}=0.85^{\prime}$

assumed water level as beginning water level from data

assumed slug $5^{\prime}$
Local ID: 3 SLUGIN 1

Date: $4 / 7 / 2004$

Time: $\mathrm{y} 0=$
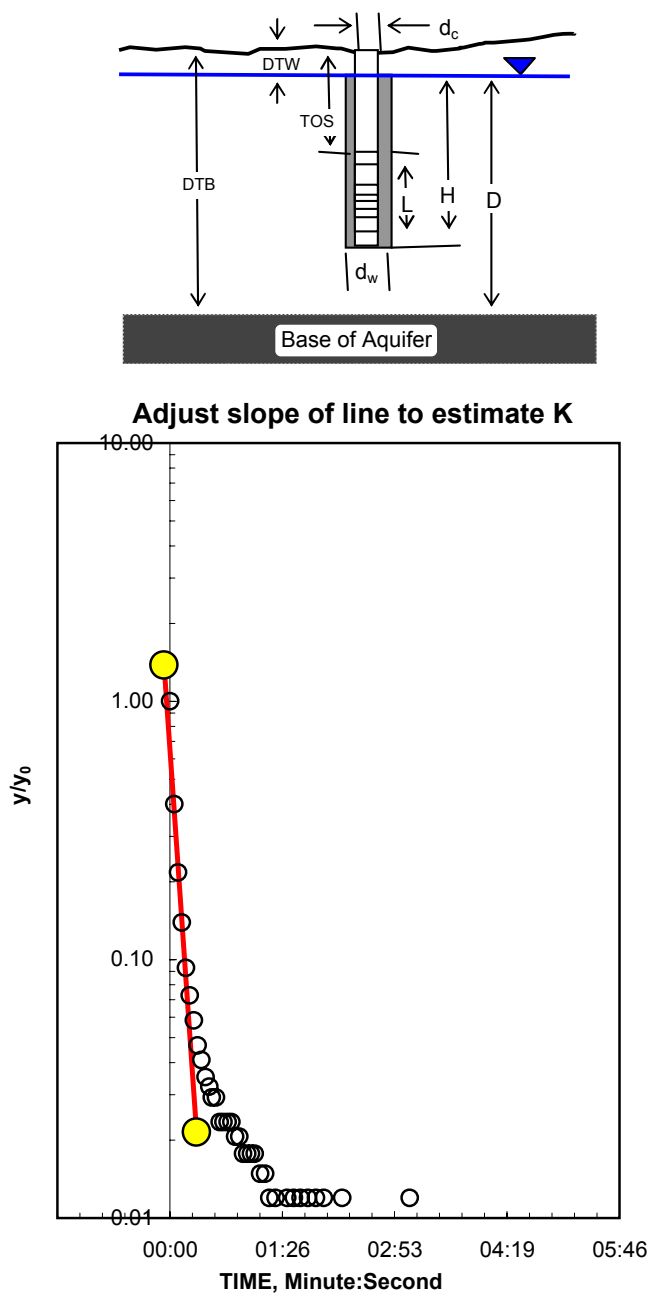

Bouwer and Rice (1976) analysis of slug test

\begin{tabular}{|c|c|c|}
\hline \multicolumn{3}{|c|}{ Reduced Data } \\
\hline & Time, & Water \\
\hline Entry & Hr:Min:Sec & Level \\
\hline 1 & 13:00:04.0 & 2.43 \\
\hline 2 & 13:00:07.0 & 3.12 \\
\hline 3 & 13:00:10.0 & 3.32 \\
\hline 4 & 13:00:13.0 & 3.41 \\
\hline 5 & 13:00:16.0 & 3.46 \\
\hline 6 & 13:00:19.0 & 3.49 \\
\hline 7 & 13:00:22.0 & 3.50 \\
\hline 8 & $13: 00: 25.0$ & 3.52 \\
\hline 9 & $13: 00: 28.0$ & 3.52 \\
\hline 10 & $13: 00: 31.0$ & 3.53 \\
\hline 11 & $13: 00: 34.0$ & 3.53 \\
\hline 12 & $13: 00: 36.0$ & 3.54 \\
\hline 13 & $13: 00: 39.0$ & 3.54 \\
\hline 14 & $13: 00: 42.0$ & 3.54 \\
\hline 15 & $13: 00: 45.0$ & 3.54 \\
\hline 16 & $13: 00: 48.0$ & 3.54 \\
\hline 17 & $13: 00: 51.0$ & 3.54 \\
\hline 18 & $13: 00: 54.0$ & 3.55 \\
\hline 19 & $13: 00: 57.0$ & 3.55 \\
\hline 20 & $13: 01: 00.0$ & 3.55 \\
\hline 21 & $13: 01: 03.0$ & 3.55 \\
\hline 22 & 13:01:06.0 & 3.55 \\
\hline 23 & 13:01:09.0 & 3.55 \\
\hline 24 & 13:01:13.0 & 3.55 \\
\hline 25 & 13:01:17.0 & 3.55 \\
\hline 26 & $13: 01: 20.0$ & 3.56 \\
\hline 27 & $13: 01: 25.0$ & 3.56 \\
\hline 28 & $13: 01: 29.0$ & 3.56 \\
\hline 29 & $13: 01: 34.0$ & 3.56 \\
\hline 30 & 13:01:39.0 & 3.56 \\
\hline 31 & $13: 01: 44.0$ & 3.56 \\
\hline 32 & 13:01:50.0 & 3.56 \\
\hline 33 & 13:01:56.0 & 3.56 \\
\hline 34 & $13: 02: 02.0$ & 3.56 \\
\hline 35 & $13: 02: 09.0$ & 3.56 \\
\hline 36 & $13: 02: 16.0$ & 3.56 \\
\hline 37 & $13: 02: 23.0$ & 3.56 \\
\hline 38 & $13: 02: 31.0$ & 3.56 \\
\hline 39 & $13: 02: 40.0$ & 3.56 \\
\hline 40 & $13: 02: 49.0$ & 3.56 \\
\hline 41 & $13: 02: 58.0$ & 3.56 \\
\hline 42 & $13: 03: 08.0$ & 3.56 \\
\hline 43 & $13: 03: 19.0$ & 3.56 \\
\hline 44 & $13: 03: 30.0$ & 3.56 \\
\hline 45 & $13: 03: 42.0$ & 3.56 \\
\hline
\end{tabular}


Appendix 1A. Slug-test results for wells at the Triangle aquifer-test site in the Little Contentnea Creek basin, Greene County, North Carolina, 2002-03. - Continued

WELL ID: TS-3 SLUGOUT 1

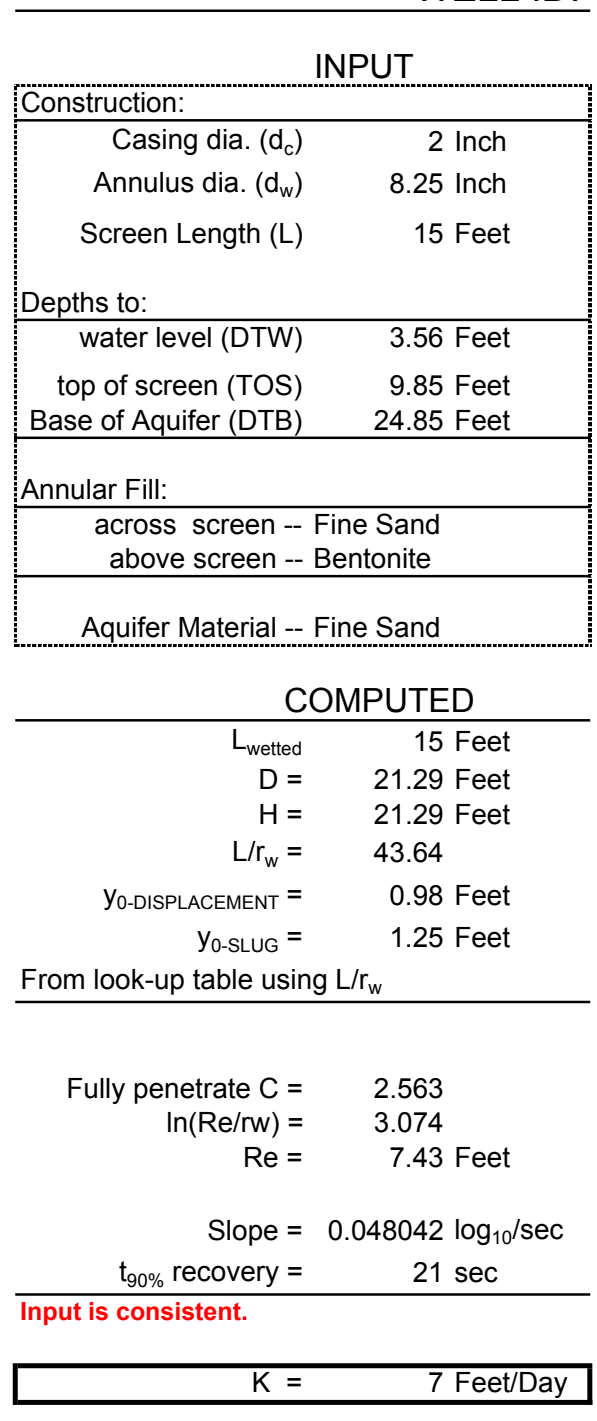

REMARKS:
Bouwer and Rice (1976) analysis of slug test

Local ID: TS-3 SLUGOUT 1

Date: $4 / 7 / 2004$

Time: $y 0=$

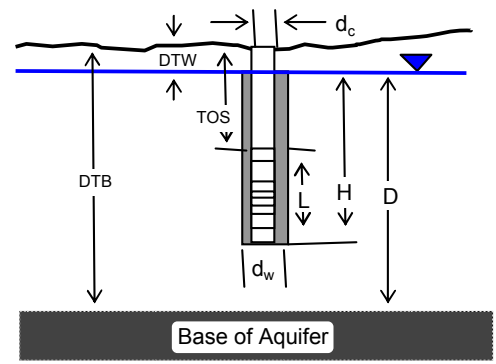

Adjust slope of line to estimate K

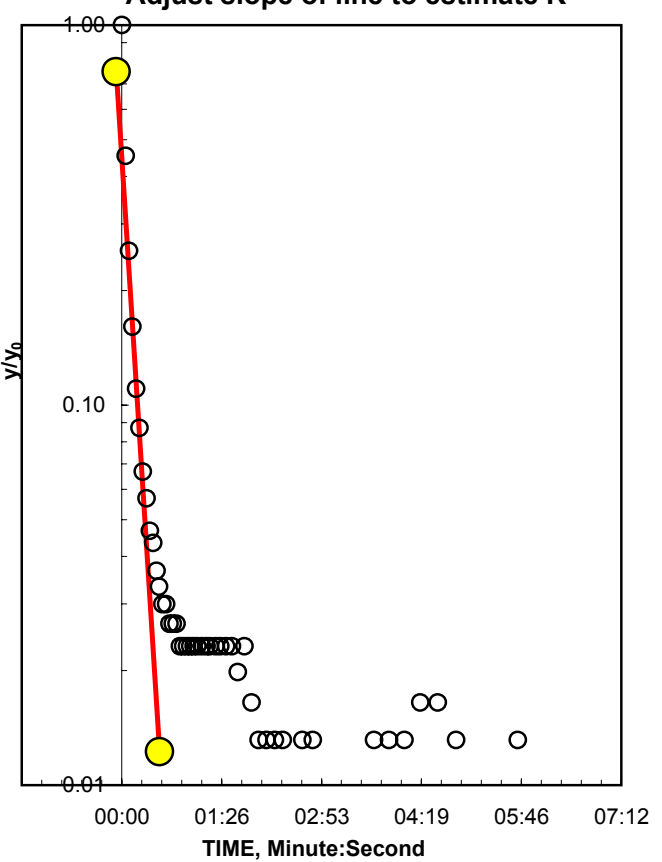

Assumed annulus 8.25

mw-0.85

assumed water level as beginning water level from data

assumed slug 5'

\begin{tabular}{|c|c|c|}
\hline \multicolumn{3}{|c|}{ Reduced Data } \\
\hline & Time, & Water \\
\hline Entry & Hr:Min:Sec & Level \\
\hline 1 & 13:07:49.0 & 4.54 \\
\hline 2 & $13: 07: 52.0$ & 4.00 \\
\hline 3 & $13: 07: 55.0$ & 3.81 \\
\hline 4 & $13: 07: 58.0$ & 3.72 \\
\hline 5 & 13:08:01.0 & 3.67 \\
\hline 6 & 13:08:04.0 & 3.65 \\
\hline 7 & 13:08:07.0 & 3.63 \\
\hline 8 & 13:08:10.0 & 3.62 \\
\hline 9 & 13:08:13.0 & 3.61 \\
\hline 10 & $13: 08: 16.0$ & 3.60 \\
\hline 11 & 13:08:19.0 & 3.60 \\
\hline 12 & $13: 08: 21.0$ & 3.59 \\
\hline 13 & $13: 08: 24.0$ & 3.59 \\
\hline 14 & 13:08:27.0 & 3.59 \\
\hline 15 & 13:08:30.0 & 3.59 \\
\hline 16 & 13:08:33.0 & 3.59 \\
\hline 17 & $13: 08: 36.0$ & 3.59 \\
\hline 18 & 13:08:39.0 & 3.58 \\
\hline 19 & $13: 08: 42.0$ & 3.58 \\
\hline 20 & $13: 08: 45.0$ & 3.58 \\
\hline 21 & 13:08:48.0 & 3.58 \\
\hline 22 & 13:08:51.0 & 3.58 \\
\hline 23 & 13:08:54.0 & 3.58 \\
\hline 24 & 13:08:58.0 & 3.58 \\
\hline 25 & 13:09:02.0 & 3.58 \\
\hline 26 & 13:09:05.0 & 3.58 \\
\hline 27 & 13:09:10.0 & 3.58 \\
\hline 28 & 13:09:14.0 & 3.58 \\
\hline 29 & 13:09:19.0 & 3.58 \\
\hline 30 & $13: 09: 24.0$ & 3.58 \\
\hline 31 & $13: 09: 29.0$ & 3.58 \\
\hline 32 & 13:09:35.0 & 3.58 \\
\hline 33 & 13:09:41.0 & 3.58 \\
\hline 34 & 13:09:47.0 & 3.57 \\
\hline 35 & $13: 09: 54.0$ & 3.57 \\
\hline 36 & $13: 10: 01.0$ & 3.57 \\
\hline 37 & $13: 10: 08.0$ & 3.57 \\
\hline 38 & $13: 10: 16.0$ & 3.57 \\
\hline 39 & $13: 10: 25.0$ & 3.57 \\
\hline 40 & $13: 10: 34.0$ & 3.57 \\
\hline 41 & $13: 10: 43.0$ & 3.57 \\
\hline 42 & $13: 10: 53.0$ & 3.57 \\
\hline 43 & $13: 11: 04.0$ & 3.57 \\
\hline 44 & $13: 11: 15.0$ & 3.57 \\
\hline 45 & $13: 11: 27.0$ & 3.57 \\
\hline
\end{tabular}


Appendix 1A. Slug-test results for wells at the Triangle aquifer-test site in the Little Contentnea Creek basin, Greene County, North Carolina, 2002-03. - Continued

WELL ID: TS-5 SLUGIN1

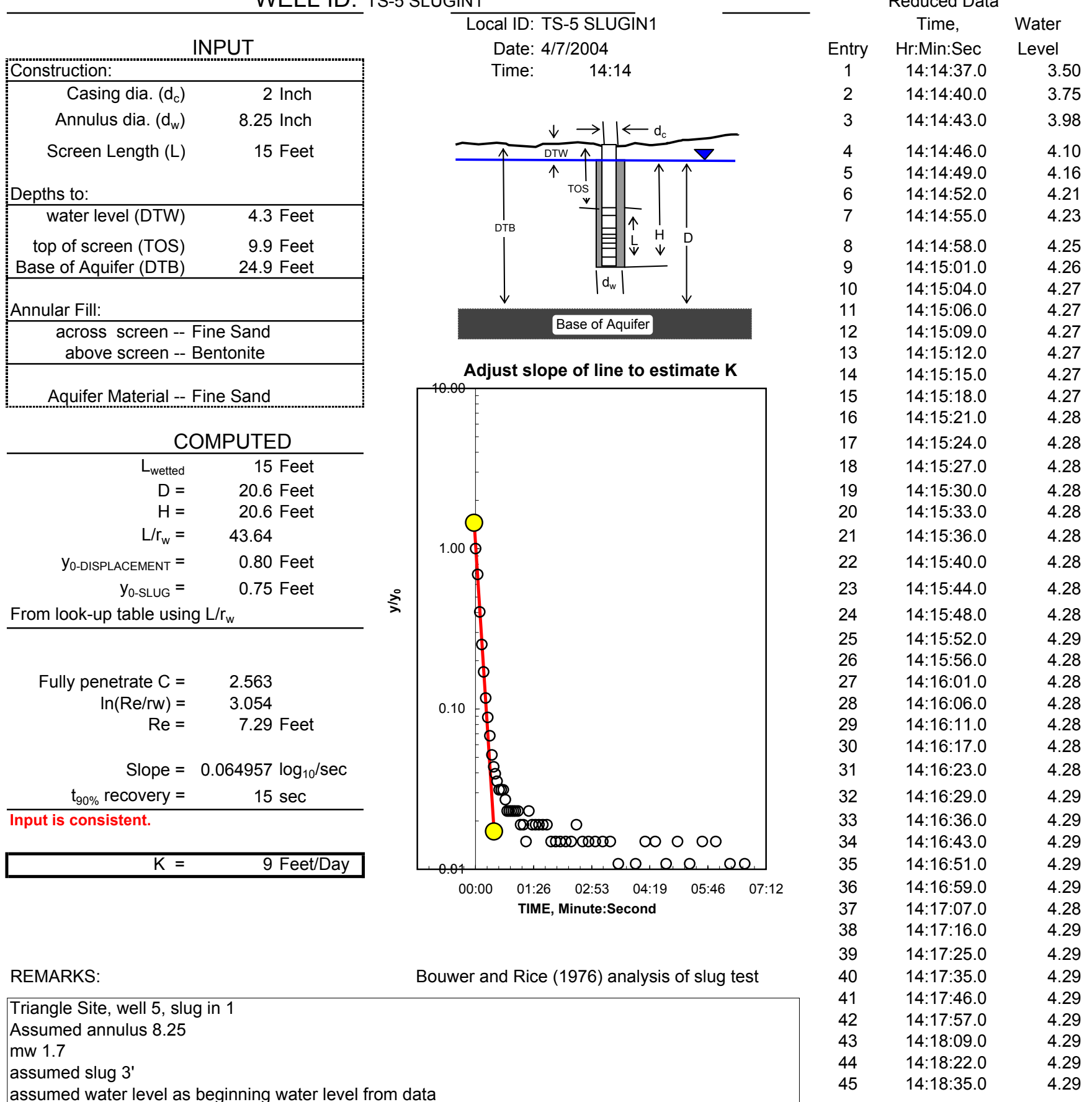


Appendix 1A. Slug-test results for wells at the Triangle aquifer-test site in the Little Contentnea Creek basin, Greene County, North Carolina, 2002-03. - Continued

WELL ID: TS-5 SLUGOUT 1

\begin{tabular}{|c|c|}
\hline \multicolumn{2}{|c|}{ INPUT } \\
\hline \multicolumn{2}{|l|}{ Construction: } \\
\hline Casing dia. $\left(\mathrm{d}_{\mathrm{c}}\right)$ & 2 Inch \\
\hline Annulus dia. $\left(\mathrm{d}_{\mathrm{w}}\right)$ & 8.25 Inch \\
\hline Screen Length (L) & 15 Feet \\
\hline \multicolumn{2}{|l|}{ Depths to: } \\
\hline water level (DTW) & 4.3 Feet \\
\hline top of screen (TOS) & 9.9 Feet \\
\hline Base of Aquifer (DTB) & 24.9 Feet \\
\hline \multicolumn{2}{|l|}{ Annular Fill: } \\
\hline \multicolumn{2}{|c|}{$\begin{array}{c}\text { across screen -- Fine Sand } \\
\text { above screen -- Bentonite }\end{array}$} \\
\hline \multicolumn{2}{|c|}{ Aquifer Material -- Fine Sand } \\
\hline \multicolumn{2}{|c|}{ COMPUTED } \\
\hline $\mathrm{L}_{\text {wetted }}$ & 15 Feet \\
\hline$D=$ & 20.6 Feet \\
\hline $\mathrm{H}=$ & 20.6 Feet \\
\hline $\mathrm{L} / \mathrm{r}_{\mathrm{w}}=$ & 43.64 \\
\hline $\mathrm{y}_{0 \text {-DISPLACEMENT }}=$ & 0.84 Feet \\
\hline $\mathrm{y}_{0-S L U G}=$ & 0.75 Feet \\
\hline \multicolumn{2}{|c|}{ From look-up table using $\mathrm{L} / \mathrm{r}_{\mathrm{w}}$} \\
\hline
\end{tabular}

Fully penetrate $\mathrm{C}=\quad 2.563$ $\ln (\mathrm{Re} / \mathrm{rw})=3.054$ $\operatorname{Re}=\quad 7.29$ Feet

Slope $=0.05752 \log _{10} / \mathrm{sec}$ $t_{90 \%}$ recovery $=$ $17 \mathrm{sec}$ Input is consistent.

$\mathrm{K}=\quad 8 \mathrm{Feet} /$ Day

REMARKS:

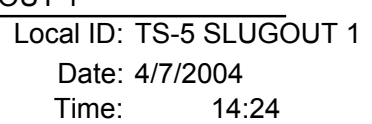

Time: $\quad 14: 24$

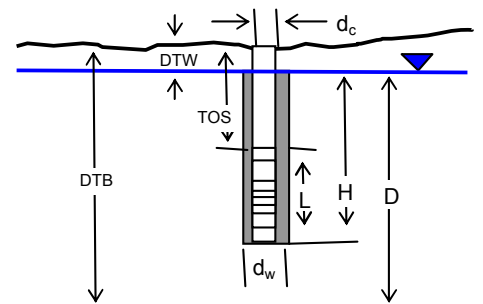

Base of Aquifer

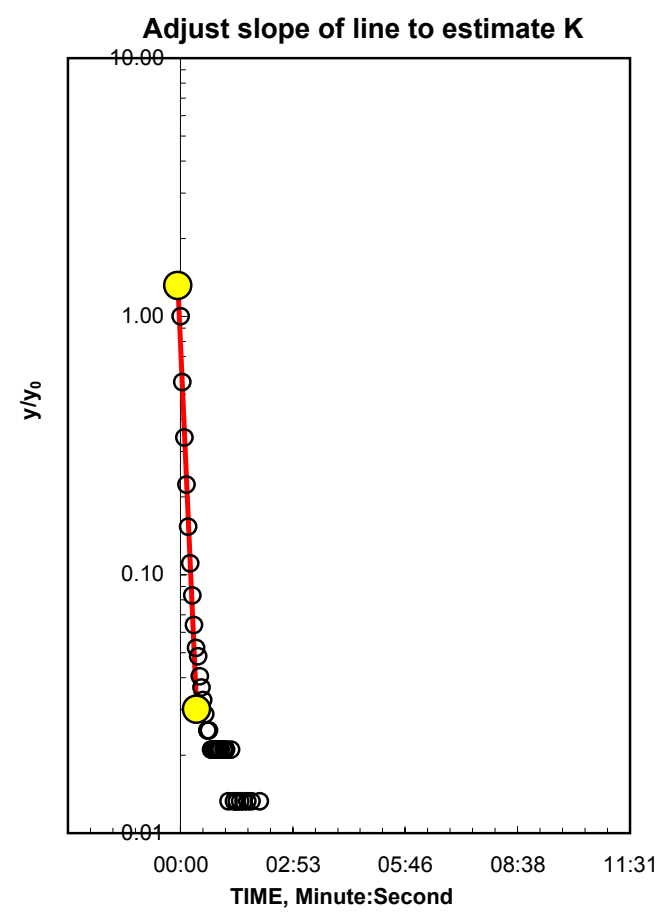

Bouwer and Rice (1976) analysis of slug test

Triangle Site, well 5, slug out 1

Assumed annulus 8.25

mw 1.7'

assumed water level as beginning water level from data

assumed slug $3^{\prime}$ 
Appendix 1B. Slug-test results for wells at the Barrett's Farm aquifer-test site in the Little Contentnea Creek basin, Greene County, North Carolina, 2002-03.

WELL ID: CBW-1 SLUGIN 1

\begin{tabular}{|c|c|}
\hline \multicolumn{2}{|c|}{ INPUT } \\
\hline \multicolumn{2}{|l|}{ Construction: } \\
\hline Casing dia. $\left(\mathrm{d}_{\mathrm{c}}\right)$ & 4 Inch \\
\hline Annulus dia. $\left(\mathrm{d}_{\mathrm{w}}\right)$ & 10.25 Inch \\
\hline Screen Length (L) & 15 Feet \\
\hline \multicolumn{2}{|l|}{ Depths to: } \\
\hline water level (DTW) & 5.7 Feet \\
\hline top of screen (TOS) & 10.54 Feet \\
\hline Base of Aquifer (DTB) & 25.54 Feet \\
\hline \multicolumn{2}{|c|}{ Annular Fill: } \\
\hline \multicolumn{2}{|c|}{$\begin{array}{c}\text { across screen -- Coarse Sand } \\
\text { above screen -- Bentonite }\end{array}$} \\
\hline \multicolumn{2}{|c|}{ Aquifer Material -- Fine Sand } \\
\hline \multicolumn{2}{|c|}{ COMPUTED } \\
\hline $\mathrm{L}_{\text {wetted }}$ & 15 Feet \\
\hline$D=$ & 19.84 Feet \\
\hline $\mathrm{H}=$ & 19.84 Feet \\
\hline $\mathrm{L} / \mathrm{r}_{\mathrm{w}}=$ & 35.12 \\
\hline $\mathrm{y}_{0 \text {-DISPLACEMENT }}=$ & 1.48 Feet \\
\hline $\mathrm{y}_{0-S L U G}=$ & 1.95 Feet \\
\hline \multicolumn{2}{|c|}{ From look-up table using $\mathrm{L} / \mathrm{r}_{\mathrm{w}}$} \\
\hline Fully penetrate $\mathrm{C}=$ & 2.283 \\
\hline $\ln (\mathrm{Re} / \mathrm{rw})=$ & 2.844 \\
\hline $\operatorname{Re}=$ & 7.34 Feet \\
\hline Slope $=$ & $0.011561 \log _{10} / \mathrm{sec}$ \\
\hline $\mathrm{t}_{90 \%}$ recovery $=$ & $87 \mathrm{sec}$ \\
\hline \multicolumn{2}{|l|}{ Input is consistent. } \\
\hline $\begin{array}{l}\mathrm{K}= \\
\mathrm{T}=\end{array}$ & $\begin{array}{l}6.1 \text { Feet/Day } \\
120 \text { Feet2/Day }\end{array}$ \\
\hline
\end{tabular}

\begin{tabular}{cc}
\hline Local ID: CBW-1 SLUGIN 1 \\
Date: & $5 / 25 / 2004$ \\
Time: & $11: 17$
\end{tabular}
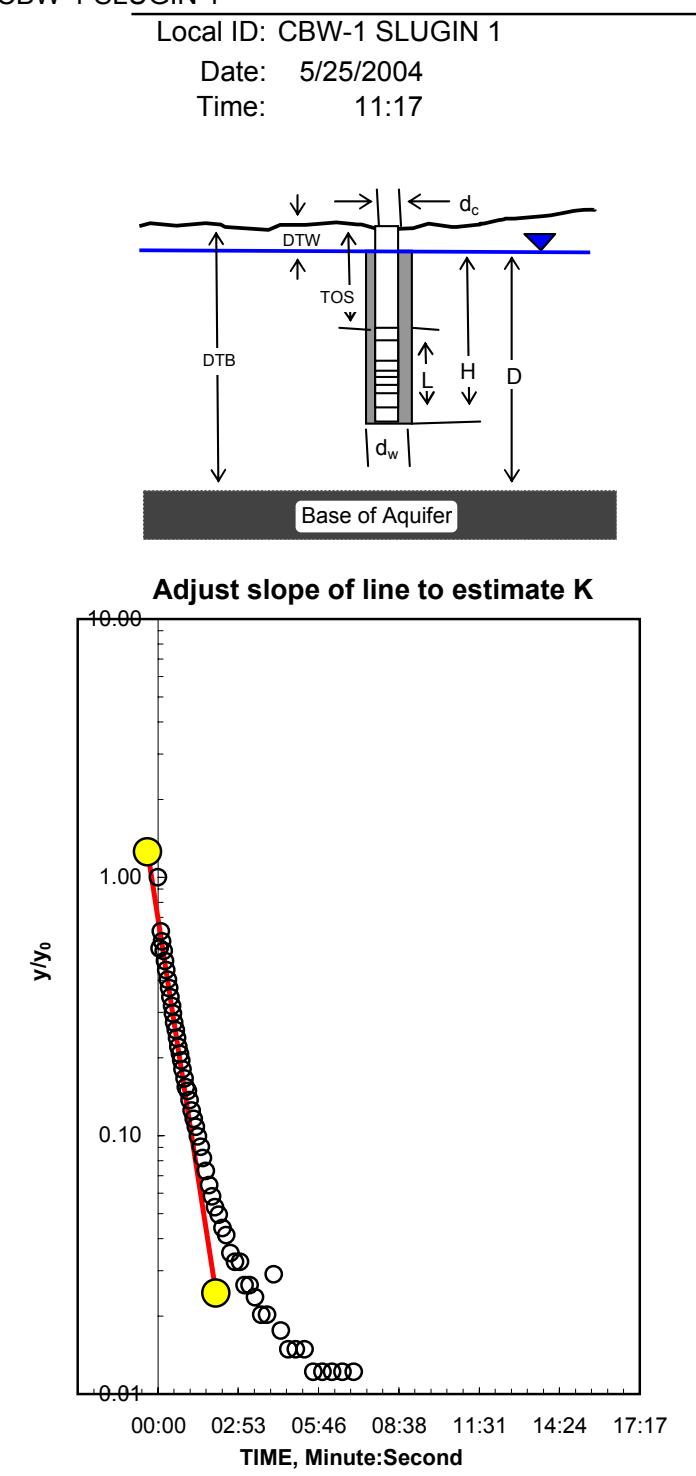

REMARKS:
Bouwer and Rice (1976) analysis of slug test

Barrett's Farm site, well 1, slug in 1 assumed annulus dia 10.25

assumed slug length 5

$\begin{array}{ccc} & \text { Reduced Data } & \\ & \text { Time, } & \text { Water } \\ \text { Entry } & \text { Hr:Min:Sec } & \text { Level } \\ 1 & 11: 17: 42.0 & 4.22 \\ 2 & 11: 17: 45.0 & 4.92 \\ 3 & 11: 17: 48.0 & 4.79 \\ 4 & 11: 17: 51.0 & 4.87 \\ 5 & 11: 17: 54.0 & 4.93 \\ 6 & 11: 17: 57.0 & 5.00 \\ 7 & 11: 18: 00.0 & 5.05 \\ 8 & 11: 18: 03.0 & 5.11 \\ 9 & 11: 18: 06.0 & 5.15 \\ 10 & 11: 18: 09.0 & 5.19 \\ 11 & 11: 18: 12.0 & 5.23 \\ 12 & 11: 18: 14.0 & 5.26 \\ 13 & 11: 18: 17.0 & 5.30 \\ 14 & 11: 18: 20.0 & 5.32 \\ 15 & 11: 18: 23.0 & 5.35 \\ 16 & 11: 18: 26.0 & 5.37 \\ 17 & 11: 18: 29.0 & 5.39 \\ 18 & 11: 18: 32.0 & 5.41 \\ 19 & 11: 18: 35.0 & 5.43 \\ 20 & 11: 18: 39.0 & 5.45 \\ 21 & 11: 18: 42.0 & 5.47 \\ 22 & 11: 18: 46.0 & 5.48 \\ 23 & 11: 18: 50.0 & 5.50 \\ 24 & 11: 18: 54.0 & 5.52 \\ 25 & 11: 18: 59.0 & 5.53 \\ 26 & 11: 19: 03.0 & 5.54 \\ 27 & 11: 19: 08.0 & 5.55 \\ 28 & 11: 19: 14.0 & 5.57 \\ 29 & 11: 19: 19.0 & 5.58 \\ 30 & 11: 19: 25.0 & 5.59 \\ 31 & 11: 19: 32.0 & 5.61 \\ 32 & 11: 19: 38.0 & 5.61 \\ 35 & 11: 21: 24.0 & 5.67 \\ 33 & 11: 19: 45.0 & 5.62 \\ 34 & 11: 19: 53.0 & 5.63 \\ 35 & 11: 20: 01.0 & 5.64 \\ 36 & 11: 20: 09.0 & 5.64 \\ 37 & 11: 20: 18.0 & 5.65 \\ 38 & 11: 20: 28.0 & 5.65 \\ 39 & 11: 20: 38.0 & 5.65 \\ 40 & 11: 20: 48.0 & 5.66 \\ & 11: 20: 59.0 & 5.66 \\ 11 & 11: 21: 11.0 & 5.67 \\ 43 & & 5.66\end{array}$


Appendix 1B. Slug-test results for wells at the Barrett's Farm aquifer-test site in the Little Contentnea Creek basin, Greene County, North Carolina, 2002-03. - Continued

WELL ID: CBW-1 SLUGOUT 2

\begin{tabular}{|c|c|}
\hline \multicolumn{2}{|c|}{ INPUT } \\
\hline \multicolumn{2}{|l|}{ Construction: } \\
\hline Casing dia. $\left(\mathrm{d}_{\mathrm{c}}\right)$ & 4 Inch \\
\hline Annulus dia. $\left(d_{w}\right)$ & 10.25 Inch \\
\hline Screen Length (L) & 15 Feet \\
\hline \multicolumn{2}{|l|}{ Depths to: } \\
\hline water level (DTW) & 5.7 Feet \\
\hline top of screen (TOS) & 10.54 Feet \\
\hline Base of Aquifer (DTB) & 25.54 Feet \\
\hline \multicolumn{2}{|c|}{ Annular Fill: } \\
\hline \multicolumn{2}{|c|}{$\begin{array}{c}\text { across screen -- Fine Sand } \\
\text { above screen -- Bentonite }\end{array}$} \\
\hline \multicolumn{2}{|c|}{ Aquifer Material -- Fine Sand } \\
\hline \multicolumn{2}{|c|}{ COMPUTED } \\
\hline $\mathrm{L}_{\text {wetted }}$ & 15 Feet \\
\hline$D=$ & 19.84 Feet \\
\hline $\mathrm{H}=$ & 19.84 Feet \\
\hline $\mathrm{L} / \mathrm{r}_{\mathrm{w}}=$ & 35.12 \\
\hline $\mathrm{y}_{0 \text {-DISPLACEMENT }}=$ & 1.05 Feet \\
\hline $\mathrm{y}_{0-\text { SLUG }}=$ & 1.95 Feet \\
\hline \multicolumn{2}{|c|}{ From look-up table using $\mathrm{L} / \mathrm{r}_{\mathrm{w}}$} \\
\hline Fully penetrate $\mathrm{C}=$ & 2.283 \\
\hline $\ln (\mathrm{Re} / \mathrm{rw})=$ & 2.844 \\
\hline $\operatorname{Re}=$ & 7.34 Feet \\
\hline Slope $=$ & $0.011069 \log _{10} / \mathrm{sec}$ \\
\hline$t_{90 \%}$ recovery $=$ & $90 \mathrm{sec}$ \\
\hline \multicolumn{2}{|l|}{ Input is consistent. } \\
\hline $\mathrm{K}=$ & 5.8 Feet/Day \\
\hline$T=$ & 120 Feet2/Day \\
\hline
\end{tabular}

Local ID: CBW-1 SLUGOUT 2

Date: $5 / 25 / 2004$

Time: $\quad 14: 16$

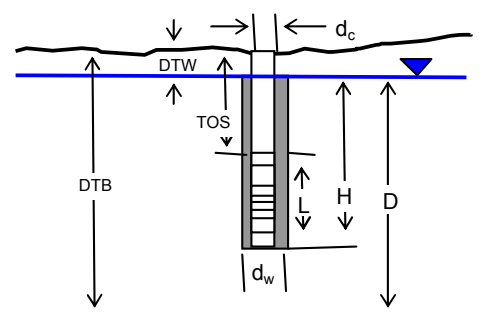

Base of Aquifer

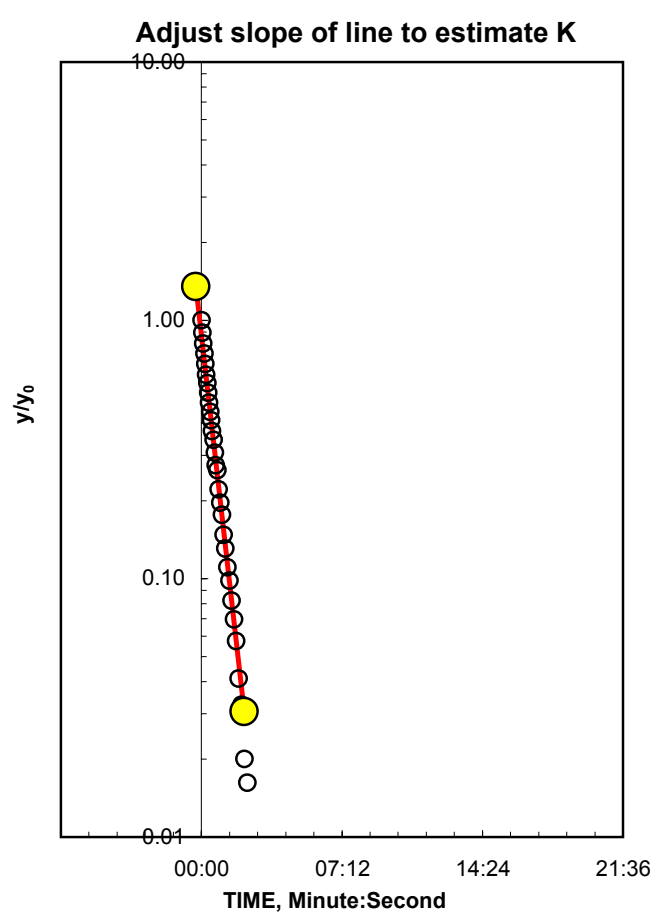

REMARKS:

Bouwer and Rice (1976) analysis of slug test
Reduced Data Time,

Hr:Min:Sec

14:16:59.0

$14: 17: 02.0$

14:17:05.0

$14: 17: 08.0$

$14: 17: 11.0$

$14: 17: 14.0$

$14: 17: 17.0$

$14: 17: 20.0$

$14: 17: 23.0$

$14: 17: 26.0$

$14: 17: 29.0$

14:17:32.0

$14: 17: 36.0$

$14: 17: 40.0$

$14: 17: 43.0$

$14: 17: 48.0$

$14: 17: 52.0$

$14: 17: 57.0$

14:18:02.0

14:18:07.0

$14: 18: 13.0$

14:18:19.0

$14: 18: 25.0$

14:18:32.0

14:18:39.0

$14: 18: 46.0$

14:18:54.0

14:19:03.0

$14: 19: 12.0$

$14: 19: 21.0$

14:19:31.0

$14: 19: 42.0$

14:19:53.0

$14: 20: 05.0$

$14: 20: 18.0$

14:20:31.0

$14: 20: 45.0$

14:21:00.0

$14: 21: 16.0$

$14: 21: 33.0$

14:21:51.0

14:22:09.0

$14: 22: 29.0$

14:22:51.0

14:23:13.0
Water

Level

6.75

6.64

6.55

6.48

6.41

6.35

6.30

6.25

6.20

6.16

6.13

6.09

6.06

6.02

5.99

5.98

5.93

5.91

5.89

5.86

5.84

5.82

5.80

5.79

5.77

5.76

5.74

5.73

5.72

5.72

5.71

5.70

5.70

5.69

5.69

5.68

5.68

5.68

5.67

5.67

5.67

5.67

5.67

5.67

5.66 
Appendix 1B. Slug-test results for wells at the Barrett's Farm aquifer-test site in the Little Contentnea Creek basin, Greene County, North Carolina, 2002-03. _ Continued

WELL ID: CBW-2 SLUGIN 2

\begin{tabular}{|c|c|}
\hline & NPUT \\
\hline \multicolumn{2}{|l|}{ Construction: } \\
\hline Casing dia. $\left(\mathrm{d}_{\mathrm{c}}\right)$ & 2 Inch \\
\hline Annulus dia. $\left(\mathrm{d}_{\mathrm{w}}\right)$ & 8.25 Inch \\
\hline Screen Length (L) & 15 Feet \\
\hline \multicolumn{2}{|l|}{ Depths to: } \\
\hline water level (DTW) & 6.62 Feet \\
\hline top of screen (TOS) & 10.14 Feet \\
\hline Base of Aquifer (DTB) & 25.14 Feet \\
\hline \multicolumn{2}{|c|}{ Annular Fill: } \\
\hline \multicolumn{2}{|c|}{$\begin{array}{c}\text { across screen -- Fine Sand } \\
\text { above screen -- Bentonite }\end{array}$} \\
\hline \multicolumn{2}{|c|}{ Aquifer Material -- Fine Sand } \\
\hline \multicolumn{2}{|c|}{ COMPUTED } \\
\hline$L_{\text {wetted }}$ & 15 Feet \\
\hline$D=$ & 18.52 Feet \\
\hline$H=$ & 18.52 Feet \\
\hline $\mathrm{L} / \mathrm{r}_{\mathrm{w}}=$ & 43.64 \\
\hline $\mathrm{y}_{0 \text {-DISPLACEMENT }}=$ & 0.58 Feet \\
\hline $\mathrm{y}_{0-\mathrm{SLUG}}=$ & 0.75 Feet \\
\hline \multicolumn{2}{|c|}{ From look-up table using $\mathrm{L} / \mathrm{r}_{\mathrm{w}}$} \\
\hline Fully penetrate $\mathrm{C}=$ & 2.563 \\
\hline $\ln (\operatorname{Re} / r w)=$ & 2.988 \\
\hline $\operatorname{Re}=$ & 6.82 Feet \\
\hline Slope $=$ & $0.024755 \log _{10} / \mathrm{sec}$ \\
\hline$t_{90 \%}$ recovery $=$ & $40 \mathrm{sec}$ \\
\hline \multicolumn{2}{|l|}{ Input is consistent. } \\
\hline $\begin{array}{l}\mathrm{K}= \\
\mathrm{T}=\end{array}$ & $\begin{array}{l}3.4 \text { Feet/Day } \\
63 \text { Feet2/Day }\end{array}$ \\
\hline
\end{tabular}

REMARKS:

Barrett's Farm site, well 2, slug in 2 assumed annulus dia 8.25 assumed slug $5^{\prime}$
Local ID: CBW-2 SLUGIN 2

Date: $5 / 25 / 2004$

Time: $\quad 14: 46$
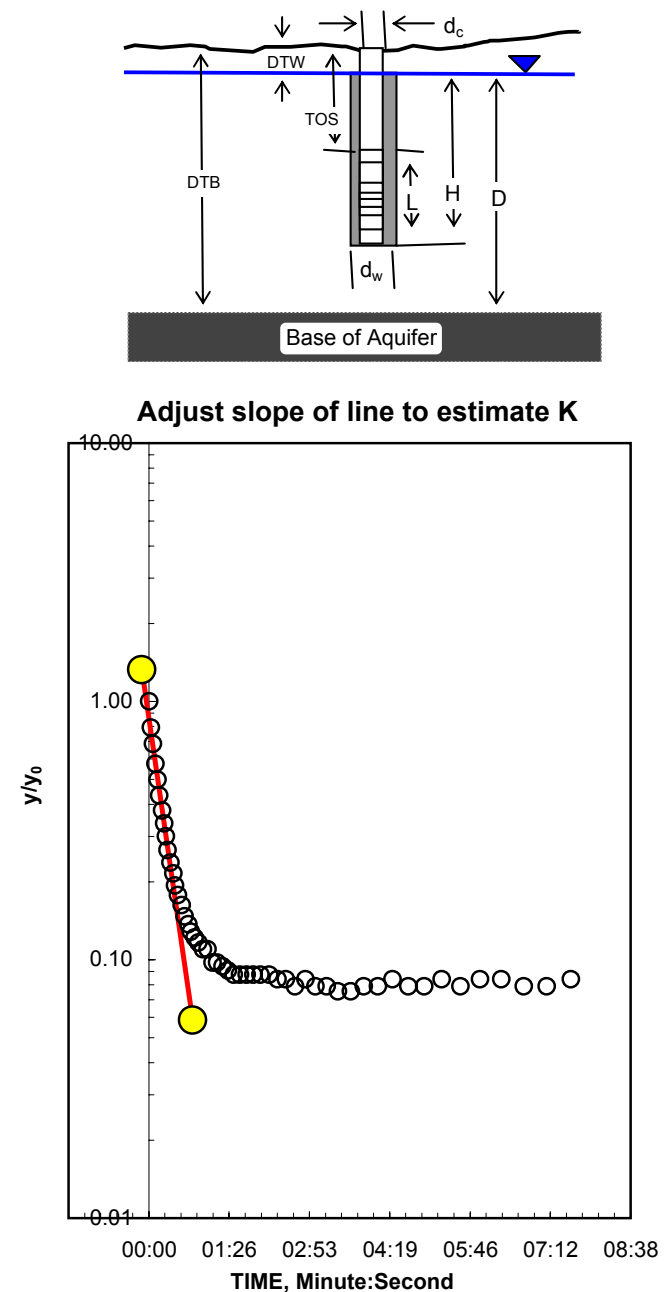

Bouwer and Rice (1976) analysis of slug test

\begin{tabular}{ccc} 
& Reduced Data & \\
& Time & Water \\
Entry & Hr:Min:Sec & Level \\
1 & $14: 46: 45.0$ & 6.04 \\
2 & $14: 46: 47.0$ & 6.16 \\
3 & $14: 46: 49.0$ & 6.22 \\
4 & $14: 46: 52.0$ & 6.29 \\
5 & $14: 46: 54.0$ & 6.33 \\
6 & $14: 46: 56.0$ & 6.37 \\
7 & $14: 46: 59.0$ & 6.40 \\
8 & $14: 47: 01.0$ & 6.42 \\
9 & $14: 47: 03.0$ & 6.45 \\
10 & $14: 47: 05.0$ & 6.47 \\
11 & $14: 47: 08.0$ & 6.48 \\
12 & $14: 47: 11.0$ & 6.49 \\
13 & $14: 47: 13.0$ & 6.51 \\
14 & $14: 47: 16.0$ & 6.52 \\
15 & $14: 47: 20.0$ & 6.53 \\
16 & $14: 47: 23.0$ & 6.53 \\
17 & $14: 47: 27.0$ & 6.54 \\
18 & $14: 47: 30.0$ & 6.55 \\
19 & $14: 47: 34.0$ & 6.55 \\
20 & $14: 47: 38.0$ & 6.55 \\
21 & $14: 47: 43.0$ & 6.56 \\
22 & $14: 47: 48.0$ & 6.56 \\
23 & $14: 47: 53.0$ & 6.56 \\
24 & $14: 47: 58.0$ & 6.56 \\
25 & $14: 48: 04.0$ & 6.57 \\
26 & $14: 48: 10.0$ & 6.57 \\
27 & $14: 48: 16.0$ & 6.57 \\
28 & $14: 48: 23.0$ & 6.57 \\
29 & $14: 48: 30.0$ & 6.57 \\
30 & $14: 48: 37.0$ & 6.57 \\
31 & $14: 48: 45.0$ & 6.57 \\
32 & $14: 48: 54.0$ & 6.57 \\
33 & $14: 49: 03.0$ & 6.57 \\
34 & $14: 49: 12.0$ & 6.57 \\
35 & $14: 49: 22.0$ & 6.57 \\
36 & $14: 49: 33.0$ & 6.57 \\
37 & $14: 49: 44.0$ & 6.57 \\
38 & $14: 49: 56.0$ & 6.57 \\
39 & $14: 50: 08.0$ & 6.58 \\
40 & $14: 50: 22.0$ & 6.58 \\
& $14: 50: 36.0$ & 6.57 \\
\hline 1 & $14: 50: 51.0$ & 6.57 \\
\hline 3 & & 6.57 \\
$34: 51: 44.0$ & 6.57 \\
\hline 3 & & 6.57
\end{tabular}


Appendix 1B. Slug-test results for wells at the Barrett's Farm aquifer-test site in the Little Contentnea Creek basin, Greene County, North Carolina, 2002-03. - Continued

WELL ID: CBW-2 SLUGOUT 1

\begin{tabular}{|c|c|}
\hline & NPUT \\
\hline \multicolumn{2}{|l|}{ Construction: } \\
\hline Casing dia. $\left(\mathrm{d}_{\mathrm{c}}\right)$ & 2 Inch \\
\hline Annulus dia. $\left(\mathrm{d}_{\mathrm{w}}\right)$ & 8.25 Inch \\
\hline Screen Length (L) & 15 Feet \\
\hline \multicolumn{2}{|l|}{ Depths to: } \\
\hline water level (DTW) & 6.62 Feet \\
\hline top of screen (TOS) & 10.14 Feet \\
\hline Base of Aquifer (DTB) & 25.14 Feet \\
\hline \multicolumn{2}{|c|}{ Annular Fill: } \\
\hline \multicolumn{2}{|c|}{$\begin{array}{c}\text { across screen -- Fine Sand } \\
\text { above screen -- Bentonite }\end{array}$} \\
\hline \multicolumn{2}{|c|}{ Aquifer Material -- Fine Sand } \\
\hline \multicolumn{2}{|c|}{ COMPUTED } \\
\hline $\mathrm{L}_{\text {wetted }}$ & 15 Feet \\
\hline$D=$ & 18.52 Feet \\
\hline $\mathrm{H}=$ & 18.52 Feet \\
\hline $\mathrm{L} / \mathrm{r}_{\mathrm{w}}=$ & 43.64 \\
\hline $\mathrm{y}_{0-\mathrm{DISPLACEMENT}}=$ & 1.05 Feet \\
\hline $\mathrm{y}_{0-S L U G}=$ & 1.25 Feet \\
\hline \multicolumn{2}{|c|}{ From look-up table using $\mathrm{L} / \mathrm{r}_{\mathrm{w}}$} \\
\hline Fully penetrate $\mathrm{C}=$ & 2.563 \\
\hline $\ln (\operatorname{Re} / r w)=$ & 2.988 \\
\hline $\operatorname{Re}=$ & 6.82 Feet \\
\hline Slope $=$ & $0.022668 \log _{10} / \mathrm{sec}$ \\
\hline$t_{90 \%}$ recovery $=$ & $44 \mathrm{sec}$ \\
\hline \multicolumn{2}{|l|}{ Input is consistent. } \\
\hline $\begin{array}{l}\mathrm{K}= \\
\mathrm{T}=\end{array}$ & $\begin{array}{c}3.1 \text { Feet/Day } \\
57 \text { Feet2/Day }\end{array}$ \\
\hline
\end{tabular}

REMARKS:

Barrett's Farm site, well 2, slug out 1 assuming annulus dia 8.25 assuming slug $5 \mathrm{ft}$
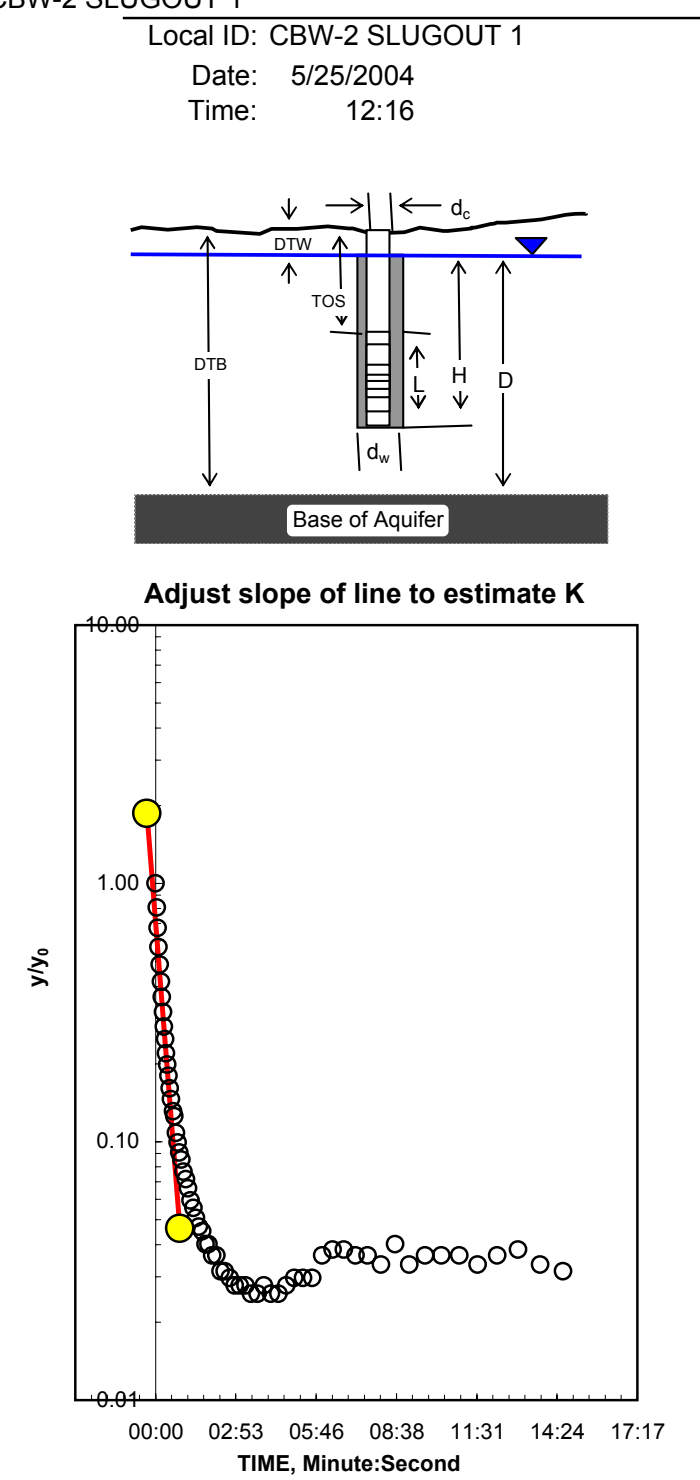

Bouwer and Rice (1976) analysis of slug test

\begin{tabular}{ccc} 
& Reduced Data & \\
& Time, & Water \\
Entry & Hr:Min:Sec & Level \\
1 & $12: 16: 37.0$ & 7.67 \\
2 & $12: 16: 39.0$ & 7.46 \\
3 & $12: 16: 41.0$ & 7.32 \\
4 & $12: 16: 43.0$ & 7.21 \\
5 & $12: 16: 46.0$ & 7.13 \\
6 & $12: 16: 48.0$ & 7.06 \\
7 & $12: 16: 50.0$ & 7.00 \\
8 & $12: 16: 53.0$ & 6.95 \\
9 & $12: 16: 55.0$ & 6.91 \\
10 & $12: 16: 57.0$ & 6.88 \\
11 & $12: 16: 59.0$ & 6.85 \\
12 & $12: 17: 02.0$ & 6.83 \\
13 & $12: 17: 05.0$ & 6.81 \\
14 & $12: 17: 07.0$ & 6.79 \\
15 & $12: 17: 10.0$ & 6.77 \\
16 & $12: 17: 14.0$ & 6.76 \\
17 & $12: 17: 17.0$ & 6.75 \\
18 & $12: 17: 21.0$ & 6.73 \\
19 & $12: 17: 24.0$ & 6.72 \\
20 & $12: 17: 28.0$ & 6.72 \\
21 & $12: 17: 32.0$ & 6.71 \\
22 & $12: 17: 37.0$ & 6.70 \\
23 & $12: 17: 42.0$ & 6.70 \\
24 & $12: 17: 47.0$ & 6.69 \\
25 & $12: 17: 52.0$ & 6.68 \\
26 & $12: 17: 58.0$ & 6.68 \\
27 & $12: 18: 04.0$ & 6.67 \\
28 & $12: 18: 10.0$ & 6.67 \\
29 & $12: 18: 17.0$ & 6.67 \\
30 & $12: 18: 24.0$ & 6.66 \\
31 & $12: 18: 31.0$ & 6.66 \\
43 & $12: 20: 45.0$ & 6.65 \\
32 & $12: 18: 39.0$ & 6.66 \\
33 & $12: 18: 48.0$ & 6.66 \\
34 & $12: 18: 57.0$ & 6.65 \\
35 & $12: 19: 06.0$ & 6.65 \\
36 & $12: 19: 16.0$ & 6.65 \\
37 & $12: 19: 27.0$ & 6.65 \\
38 & $12: 19: 38.0$ & 6.65 \\
39 & $12: 19: 50.0$ & 6.65 \\
40 & $12: 20: 02.0$ & 6.65 \\
\hline 1 & $12: 20: 16.0$ & 6.65 \\
\hline 3 & $12: 20: 30.0$ & 6.65 \\
\hline 3 & & 6.65 \\
\hline 3 & &
\end{tabular}


Appendix 1B. Slug-test results for wells at the Barrett's Farm aquifer-test site in the Little Contentnea Creek basin, Greene County, North Carolina, 2002-03. _ Continued

WELL ID: CBW-3 SLUGIN 1

\begin{tabular}{|c|c|}
\hline & NPUT \\
\hline \multicolumn{2}{|l|}{ Construction: } \\
\hline Casing dia. $\left(d_{c}\right)$ & 2 Inch \\
\hline Annulus dia. $\left(\mathrm{d}_{\mathrm{w}}\right)$ & 8.25 Inch \\
\hline Screen Length (L) & 15 Feet \\
\hline \multicolumn{2}{|l|}{ Depths to: } \\
\hline water level (DTW) & 6.45 Feet \\
\hline top of screen (TOS) & 10.45 Feet \\
\hline Base of Aquifer (DTB) & 25.45 Feet \\
\hline \multicolumn{2}{|c|}{ Annular Fill: } \\
\hline \multicolumn{2}{|c|}{$\begin{array}{c}\text { across screen -- Fine Sand } \\
\text { above screen -- Bentonite }\end{array}$} \\
\hline \multicolumn{2}{|c|}{ Aquifer Material -- Fine Sand } \\
\hline \multicolumn{2}{|c|}{ COMPUTED } \\
\hline$L_{\text {wetted }}$ & 15 Feet \\
\hline$D=$ & 19 Feet \\
\hline$H=$ & 19 Feet \\
\hline $\mathrm{L} / \mathrm{r}_{\mathrm{w}}=$ & 43.64 \\
\hline $\mathrm{y}_{0-\text { DISPLACEMENT }}=$ & 1.04 Feet \\
\hline $\mathrm{y}_{0-\text { SLUG }}=$ & 1.25 Feet \\
\hline \multicolumn{2}{|c|}{ From look-up table using $\mathrm{L} / \mathrm{r}_{\mathrm{w}}$} \\
\hline Fully penetrate $C=$ & 2.563 \\
\hline $\ln (\operatorname{Re} / r w)=$ & 3.004 \\
\hline $\operatorname{Re}=$ & 6.93 Feet \\
\hline Slope $=$ & $0.024625 \log _{10} / \mathrm{sec}$ \\
\hline$t_{90 \%}$ recovery $=$ & $41 \mathrm{sec}$ \\
\hline \multicolumn{2}{|l|}{ Input is consistent. } \\
\hline $\begin{array}{l}\mathrm{K}= \\
\mathrm{T}=\end{array}$ & $\begin{array}{c}3.4 \text { Feet/Day } \\
65 \text { Feet2/Day }\end{array}$ \\
\hline
\end{tabular}

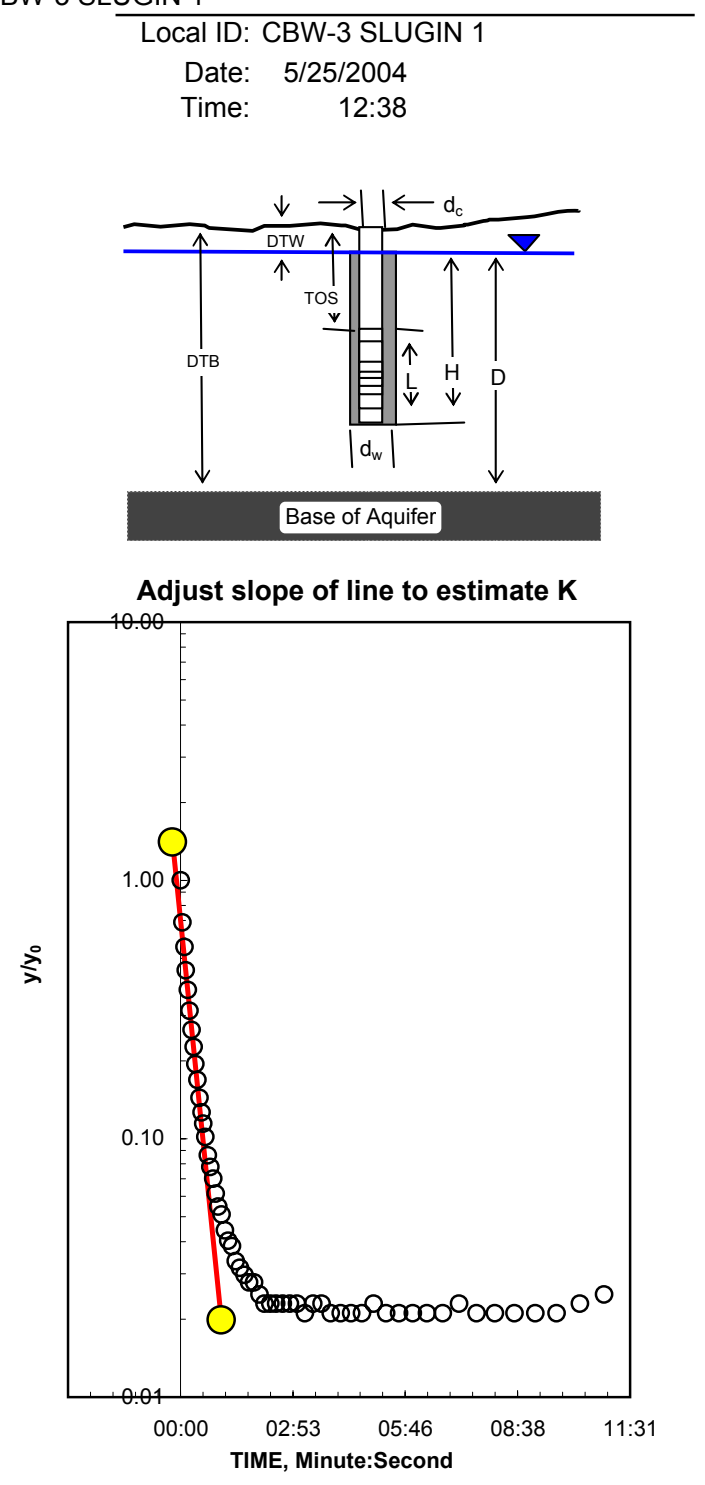

$\begin{array}{ccc} & \text { Reduced Data } & \\ & \text { Time, } & \text { Water } \\ \text { Entry } & \text { Hr:Min:Sec } & \text { Level } \\ 1 & 12: 38: 09.0 & 5.41 \\ 2 & 12: 38: 12.0 & 5.73 \\ 3 & 12: 38: 15.0 & 5.88 \\ 4 & 12: 38: 17.0 & 5.98 \\ 5 & 12: 38: 20.0 & 6.06 \\ 6 & 12: 38: 23.0 & 6.12 \\ 7 & 12: 38: 26.0 & 6.18 \\ 8 & 12: 38: 29.0 & 6.21 \\ 9 & 12: 38: 32.0 & 6.25 \\ 10 & 12: 38: 35.0 & 6.27 \\ 11 & 12: 38: 38.0 & 6.30 \\ 12 & 12: 38: 41.0 & 6.32 \\ 13 & 12: 38: 44.0 & 6.33 \\ 14 & 12: 38: 47.0 & 6.34 \\ 15 & 12: 38: 51.0 & 6.36 \\ 16 & 12: 38: 55.0 & 6.37 \\ 17 & 12: 38: 59.0 & 6.38 \\ 18 & 12: 39: 03.0 & 6.39 \\ 19 & 12: 39: 07.0 & 6.39 \\ 20 & 12: 39: 12.0 & 6.40 \\ 21 & 12: 39: 17.0 & 6.40 \\ 22 & 12: 39: 22.0 & 6.41 \\ 23 & 12: 39: 28.0 & 6.41 \\ 24 & 12: 39: 34.0 & 6.42 \\ 25 & 12: 39: 40.0 & 6.42 \\ 26 & 12: 39: 47.0 & 6.42 \\ 27 & 12: 39: 54.0 & 6.42 \\ 28 & 12: 40: 02.0 & 6.42 \\ 29 & 12: 40: 10.0 & 6.42 \\ 30 & 12: 40: 18.0 & 6.43 \\ 31 & 12: 40: 27.0 & 6.43 \\ 43 & 12: 43: 06.0 & 6.43 \\ 32 & 12: 40: 36.0 & 6.43 \\ 33 & 12: 40: 46.0 & 6.43 \\ 34 & 12: 40: 57.0 & 6.43 \\ 35 & 12: 41: 08.0 & 6.43 \\ 36 & 12: 41: 20.0 & 6.43 \\ 37 & 12: 41: 33.0 & 6.43 \\ 38 & 12: 41: 46.0 & 6.43 \\ 39 & 12: 42: 00.0 & 6.43 \\ 40 & 12: 42: 15.0 & 6.43 \\ & 12: 42: 31.0 & 6.43 \\ 43 & 12: 42: 48.0 & 6.43 \\ 34 & & 6.43 \\ & 12.43 .0 & \end{array}$

REMARKS:

Bouwer and Rice (1976) analysis of slug test

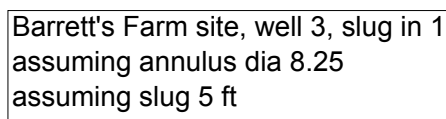


Appendix 1B. Slug-test results for wells at the Barrett's Farm aquifer-test site in the Little Contentnea Creek basin, Greene County, North Carolina, 2002-03. - Continued

WELL ID: CBW-3 SLUG OUT 1

\begin{tabular}{|c|c|}
\hline \multicolumn{2}{|c|}{ INPUT } \\
\hline \multicolumn{2}{|l|}{ Construction: } \\
\hline Casing dia. $\left(\mathrm{d}_{\mathrm{c}}\right)$ & 2 Inch \\
\hline Annulus dia. $\left(\mathrm{d}_{\mathrm{w}}\right)$ & 8.25 Inch \\
\hline Screen Length (L) & 15 Feet \\
\hline \multicolumn{2}{|l|}{ Depths to: } \\
\hline water level (DTW) & 6.45 Feet \\
\hline top of screen (TOS) & 10.45 Feet \\
\hline Base of Aquifer (DTB) & 25.45 Feet \\
\hline \multicolumn{2}{|c|}{ Annular Fill: } \\
\hline \multicolumn{2}{|c|}{$\begin{array}{c}\text { across screen -- Fine Sand } \\
\text { above screen -- Bentonite }\end{array}$} \\
\hline \multicolumn{2}{|c|}{ Aquifer Material -- Fine Sand } \\
\hline \multicolumn{2}{|c|}{ COMPUTED } \\
\hline $\mathrm{L}_{\text {wetted }}$ & 15 Feet \\
\hline$D=$ & 19 Feet \\
\hline$H=$ & 19 Feet \\
\hline $\mathrm{L} / \mathrm{r}_{\mathrm{w}}=$ & 43.64 \\
\hline $\mathrm{y}_{0-\text { DISPLACEMENT }}=$ & 0.97 Feet \\
\hline $\mathrm{y}_{0-S L U G}=$ & 1.25 Feet \\
\hline \multicolumn{2}{|c|}{ From look-up table using $\mathrm{L} / \mathrm{r}_{\mathrm{w}}$} \\
\hline Fully penetrate $\mathrm{C}=$ & 2.563 \\
\hline $\ln (\operatorname{Re} / r w)=$ & 3.004 \\
\hline $\operatorname{Re}=$ & 6.93 Feet \\
\hline Slope $=$ & $0.032079 \log _{10} / \mathrm{sec}$ \\
\hline$t_{90 \%}$ recovery $=$ & $31 \mathrm{sec}$ \\
\hline \multicolumn{2}{|l|}{ Input is consistent. } \\
\hline $\begin{array}{l}\mathrm{K}= \\
\mathrm{T}=\end{array}$ & $\begin{array}{l}4.4 \text { Feet/Day } \\
84 \text { Feet2/Day }\end{array}$ \\
\hline
\end{tabular}

REMARKS:

Barrett's Farm site, well 3, slug out 1 assuming annulus dia 8.25

assuming slug $5 \mathrm{ft}$
Local ID: CBW-3 SLUG OUT 1

Date: $5 / 25 / 2004$

Time: $\quad$ 13:03

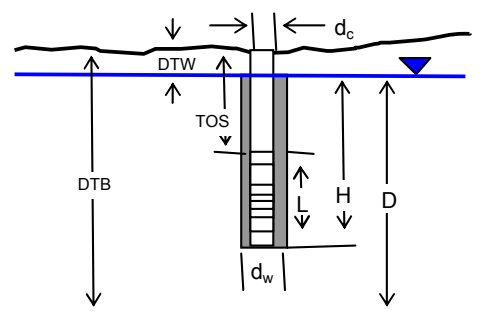

Base of Aquifer

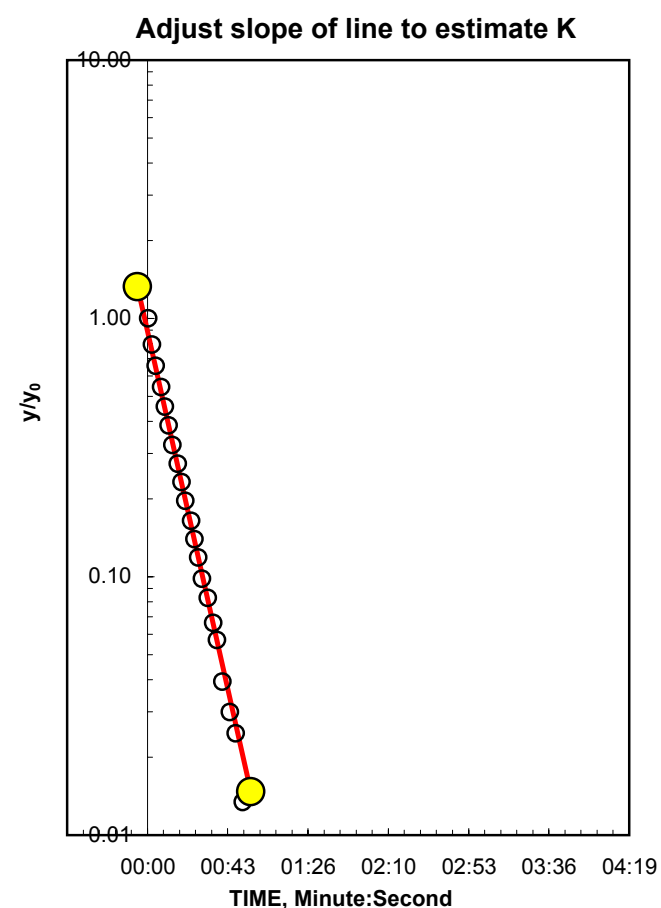

Bouwer and Rice (1976) analysis of slug test
Reduced Data Time,

Hr:Min:Sec

13:03:42.0

13:03:44.0

13:03:46.0

13:03:49.0

13:03:51.0

13:03:53.0

13:03:55.0

13:03:58.0

13:04:00.0

13:04:02.0

13:04:05.0

13:04:07.0

13:04:09.0

13:04:11.0

13:04:14.0

13:04:17.0

13:04:19.0

13:04:22.0

13:04:26.0

13:04:29.0

13:04:33.0

13:04:36.0

13:04:40.0

13:04:44.0

13:04:49.0

13:04:54.0

13:04:59.0

13:05:04.0

13:05:10.0

13:05:16.0

13:05:22.0

13:05:29.0

13:05:36.0

13:05:43.0

13:05:51.0

13:06:00.0

13:06:09.0

13:06:18.0

13:06:28.0

13:06:39.0

13:06:50.0

13:07:02.0

13:07:14.0

13:07:28.0
Water

Level

7.42

7.22

7.09

6.98

6.89

6.82

6.76

6.72

6.68

6.64

6.61

6.59

6.57

6.55

6.53

6.51

6.51

6.49

6.48

6.47

6.46

6.46

6.45

6.45

6.44

6.44

6.43

6.43

6.43

6.43

6.42

6.42

6.42

6.42

6.42

6.42

6.42

6.42

6.42

6.42

6.42

6.42

6.42

6.42 
Appendix 1B. Slug-test results for wells at the Barrett's Farm aquifer-test site in the Little Contentnea Creek basin, Greene County, North Carolina, 2002-03. _ Continued

WELL ID: CBW-4 SLUGIN 2

\begin{tabular}{|c|c|}
\hline \multicolumn{2}{|c|}{ INPUT } \\
\hline \multicolumn{2}{|l|}{ Construction: } \\
\hline Casing dia. $\left(\mathrm{d}_{\mathrm{c}}\right)$ & 2 Inch \\
\hline Annulus dia. $\left(\mathrm{d}_{\mathrm{w}}\right)$ & 8.25 Inch \\
\hline Screen Length (L) & 15 Feet \\
\hline \multicolumn{2}{|l|}{ Depths to: } \\
\hline water level (DTW) & 6.35 Feet \\
\hline top of screen (TOS) & 10.45 Feet \\
\hline Base of Aquifer (DTB) & 25.45 Feet \\
\hline \multicolumn{2}{|c|}{ Annular Fill: } \\
\hline \multicolumn{2}{|c|}{$\begin{array}{c}\text { across screen -- Fine Sand } \\
\text { above screen -- Bentonite }\end{array}$} \\
\hline \multicolumn{2}{|c|}{ Aquifer Material -- Fine Sand } \\
\hline \multicolumn{2}{|c|}{ COMPUTED } \\
\hline$L_{\text {wetted }}$ & 15 Feet \\
\hline$D=$ & 19.1 Feet \\
\hline $\mathrm{H}=$ & 19.1 Feet \\
\hline $\mathrm{L} / \mathrm{r}_{\mathrm{w}}=$ & 43.64 \\
\hline $\mathrm{y}_{0-\text { DISPLACEMENT }}=$ & 0.86 Feet \\
\hline $\mathrm{y}_{0-S L U G}=$ & 0.75 Feet \\
\hline From look-up table using & \\
\hline
\end{tabular}

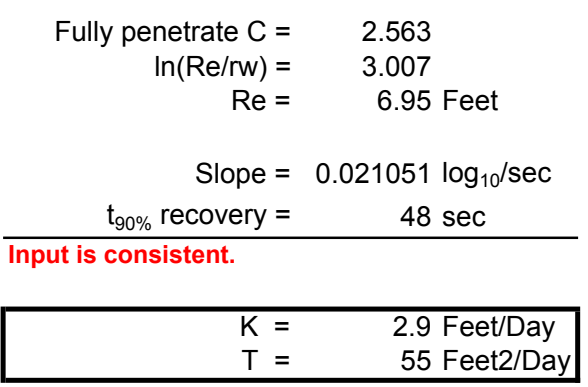

Local ID: CBW-4 SLUGIN 2

$$
\text { Date: } 5 / 25 / 2004
$$$$
\text { Time: } \quad 14: 46
$$
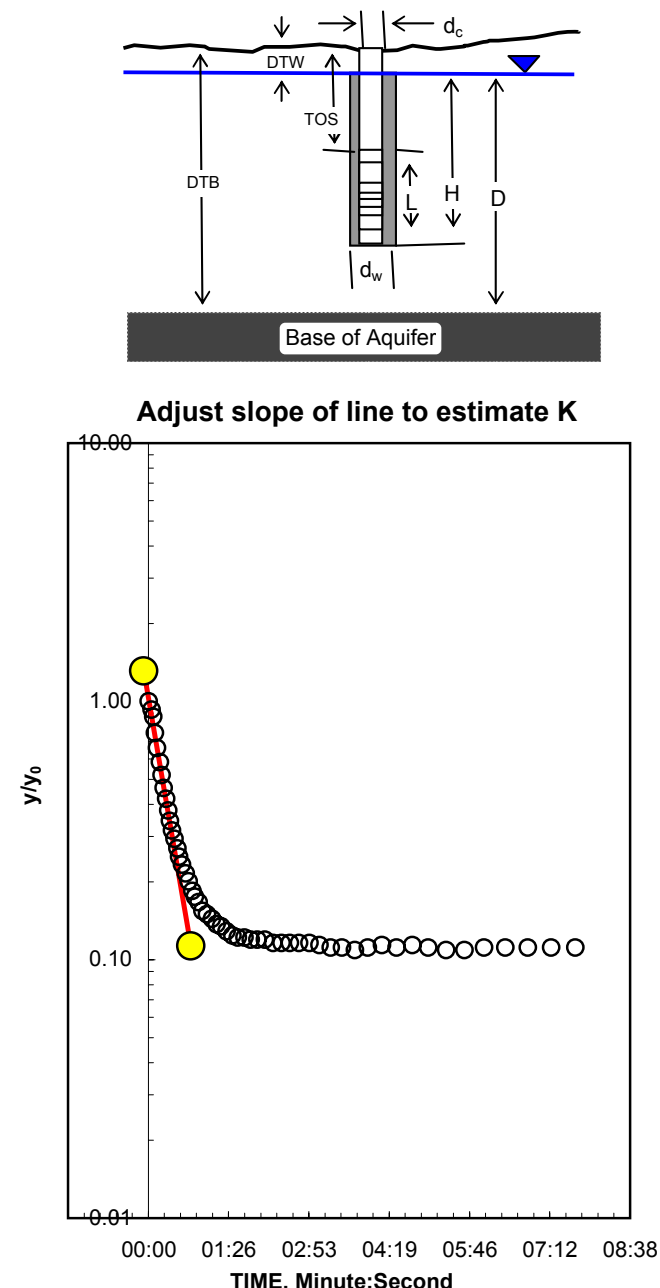

$K=2.9$ is less than likely minimum of 3 for Fine Sand REMARKS: Bouwer and Rice (1976) analysis of slug test

Barrett's Farm site, well 4, slug in 2 assuming annulus dia 8.25 assuming slug $3 \mathrm{ft}$
Reduced Data Time, Water Hr:Min:Sec Level $14: 46: 40.0 \quad 5.49$ $14: 46: 43.0 \quad 5.55$ $14: 46: 45.0 \quad 5.60$ $14: 46: 47.0 \quad 5.70$ $14: 46: 49.0 \quad 5.78$ $14: 46: 52.0 \quad 5.85$ 14:46:54.0 $\quad 5.90$

$14: 46: 56.0 \quad 5.95$

$14: 46: 59.0 \quad 5.99$

$14: 47: 01.0 \quad 6.02$

$14: 47: 03.0 \quad 6.05$

$14: 47: 05.0 \quad 6.08$

$14: 47: 08.0 \quad 6.10$

$14: 47: 11.0 \quad 6.12$

$14: 47: 13.0 \quad 6.13$

$14: 47: 16.0 \quad 6.15$

$14: 47: 20.0 \quad 6.16$

$14: 47: 23.0 \quad 6.18$

$14: 47: 27.0 \quad 6.19$

$14: 47: 30.0 \quad 6.20$

$14: 47: 34.0 \quad 6.21$

$14: 47: 38.0 \quad 6.22$

$14: 47: 43.0 \quad 6.22$

$14: 47: 48.0 \quad 6.23$

$14: 47: 53.0 \quad 6.23$

$14: 47: 58.0 \quad 6.23$

$14: 48: 04.0 \quad 6.24$

14:48:10.0 6.24

$14: 48: 16.0 \quad 6.25$

$14: 48: 23.0 \quad 6.25$

$14: 48: 30.0 \quad 6.25$

$14: 48: 37.0 \quad 6.25$

$14: 48: 45.0 \quad 6.25$

$14: 48: 54.0 \quad 6.25$

14:49:03.0 $\quad 6.25$

$14: 49: 12.0 \quad 6.25$

$14: 49: 22.0 \quad 6.25$

$14: 49: 33.0 \quad 6.25$

$14: 49: 44.0 \quad 6.25$

$14: 49: 56.0 \quad 6.25$

14:50:08.0 $\quad 6.25$

$14: 50: 22.0 \quad 6.26$

$14: 50: 36.0 \quad 6.25$

$14: 50: 51.0 \quad 6.25$

$\begin{array}{ll}14: 51: 07.0 & 6.25\end{array}$ 
Appendix 1B. Slug-test results for wells at the Barrett's Farm aquifer-test site in the Little Contentnea Creek basin, Greene County, North Carolina, 2002-03. - Continued

WELL ID: CBW-4 SLUGOUT 1

\begin{tabular}{|c|c|}
\hline \multicolumn{2}{|c|}{ INPUT } \\
\hline \multicolumn{2}{|l|}{ Construction: } \\
\hline Casing dia. $\left(\mathrm{d}_{\mathrm{c}}\right)$ & 2 Inch \\
\hline Annulus dia. $\left(\mathrm{d}_{\mathrm{w}}\right)$ & 8.25 Inch \\
\hline Screen Length (L) & 15 Feet \\
\hline \multicolumn{2}{|l|}{ Depths to: } \\
\hline water level (DTW) & 6.35 Feet \\
\hline top of screen (TOS) & 10.45 Feet \\
\hline Base of Aquifer (DTB) & 25.45 Feet \\
\hline \multicolumn{2}{|c|}{ Annular Fill: } \\
\hline \multicolumn{2}{|c|}{$\begin{array}{c}\text { across screen -- Fine Sand } \\
\text { above screen -- Bentonite }\end{array}$} \\
\hline \multicolumn{2}{|c|}{ Aquifer Material -- Fine Sand } \\
\hline \multicolumn{2}{|c|}{ COMPUTED } \\
\hline $\mathrm{L}_{\text {wetted }}$ & 15 Feet \\
\hline$D=$ & 19.1 Feet \\
\hline $\mathrm{H}=$ & 19.1 Feet \\
\hline $\mathrm{L} / \mathrm{r}_{\mathrm{w}}=$ & 43.64 \\
\hline $\mathrm{y}_{0-\mathrm{DISPLACEMENT}}=$ & 0.81 Feet \\
\hline $\mathrm{y}_{0-S L U G}=$ & 0.75 Feet \\
\hline \multicolumn{2}{|c|}{ From look-up table using $\mathrm{L} / \mathrm{r}_{\mathrm{w}}$} \\
\hline Fully penetrate $\mathrm{C}=$ & 2.563 \\
\hline $\ln (\operatorname{Re} / r w)=$ & 3.007 \\
\hline $\mathrm{Re}=$ & 6.95 Feet \\
\hline Slope $=$ & $0.033321 \log _{10} / \mathrm{sec}$ \\
\hline$t_{90 \%}$ recovery $=$ & $30 \mathrm{sec}$ \\
\hline \multicolumn{2}{|l|}{ Input is consistent. } \\
\hline $\begin{array}{l}\mathrm{K}= \\
\mathrm{T}=\end{array}$ & $\begin{array}{l}4.6 \text { Feet/Day } \\
88 \text { Feet2/Day }\end{array}$ \\
\hline
\end{tabular}
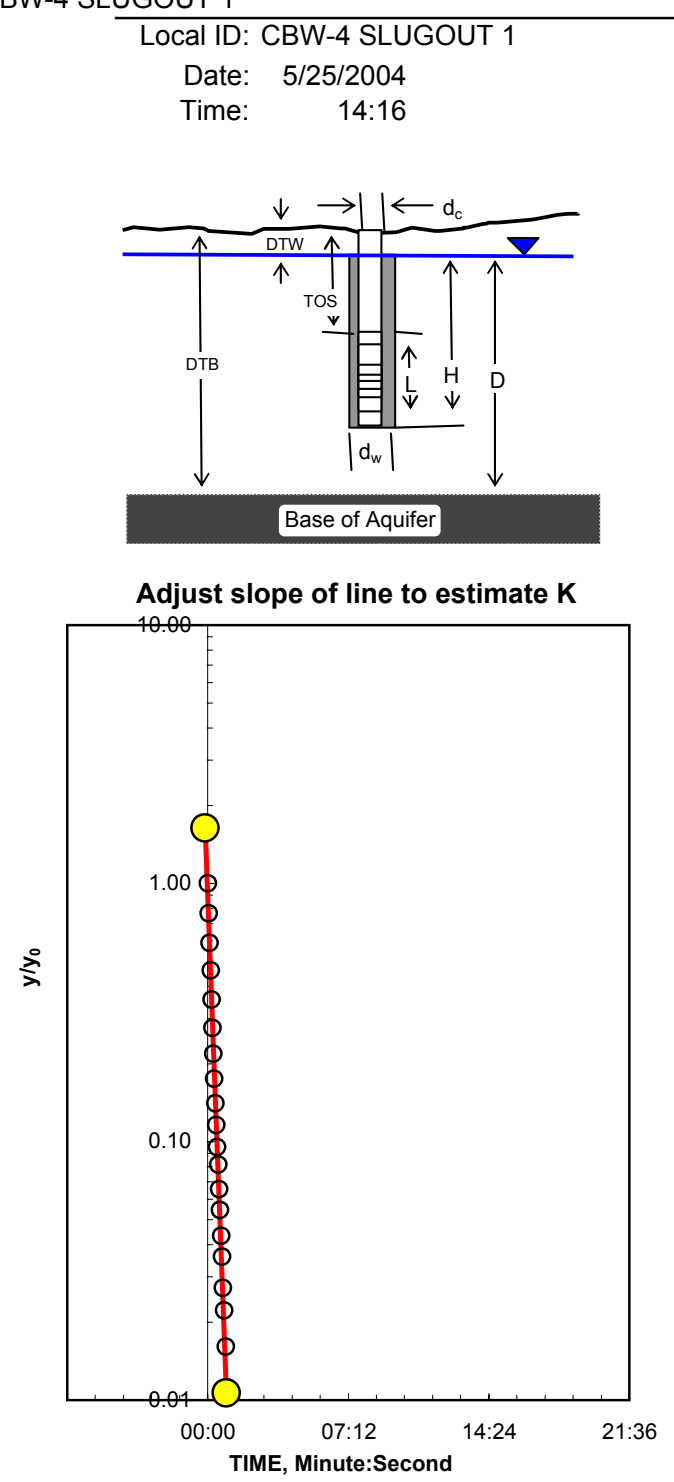

REMARKS:

Barrett's Farm site, well 4, slug out 1 assuming annulus dia 8.25

assuming slug $3 \mathrm{ft}$
Reduced Data Time, Water

Hr:Min:Sec Level 14:16:45.0 $\quad 7.16$ $14: 16: 48.0 \quad 6.97$ $14: 16: 51.0 \quad 6.83$

$14: 16: 54.0 \quad 6.72$

$14: 16: 57.0 \quad 6.64$

$14: 16: 59.0 \quad 6.57$

$14: 17: 02.0 \quad 6.53$

$14: 17: 05.0 \quad 6.49$

$14: 17: 08.0 \quad 6.46$

$14: 17: 11.0 \quad 6.44$

$14: 17: 14.0 \quad 6.43$

$14: 17: 17.0 \quad 6.42$

$14: 17: 20.0 \quad 6.40$

$14: 17: 23.0 \quad 6.39$

$14: 17: 26.0 \quad 6.39$

$14: 17: 29.0 \quad 6.38$

$14: 17: 32.0 \quad 6.37$

$14: 17: 36.0 \quad 6.37$

$14: 17: 40.0 \quad 6.36$

$14: 17: 43.0 \quad 6.36$

$14: 17: 48.0 \quad 6.36$

$14: 17: 52.0 \quad 6.35$

$14: 17: 57.0 \quad 6.35$

$14: 18: 02.0 \quad 6.34$

$14: 18: 07.0 \quad 6.34$

$14: 18: 13.0 \quad 6.34$

$14: 18: 19.0 \quad 6.33$

$14: 18: 25.0 \quad 6.33$

$14: 18: 32.0 \quad 6.33$

$14: 18: 39.0 \quad 6.32$

$14: 18: 46.0 \quad 6.32$

$14: 18: 54.0 \quad 6.32$

14:19:03.0 6.32

$14: 19: 12.0 \quad 6.31$

$14: 19: 21.0 \quad 6.31$

$14: 19: 31.0 \quad 6.31$

$14: 19: 42.0 \quad 6.30$

$14: 19: 53.0 \quad 6.30$

$14: 20: 05.0 \quad 6.30$

$14: 20: 18.0 \quad 6.29$

$14: 20: 31.0 \quad 6.29$

$14: 20: 45.0 \quad 6.29$

$14: 21: 00.0 \quad 6.29$

$14: 21: 16.0 \quad 6.29$

$\begin{array}{ll}14: 21: 33.0 & 6.29\end{array}$ 
Appendix 1B. Slug-test results for wells at the Barrett's Farm aquifer-test site in the Little Contentnea Creek basin, Greene County, North Carolina, 2002-03. _ Continued

WELL ID: CBW-5 SLUGIN 2

\begin{tabular}{|c|c|}
\hline & NPUT \\
\hline \multicolumn{2}{|l|}{ Construction: } \\
\hline Casing dia. $\left(\mathrm{d}_{\mathrm{c}}\right)$ & 2 Inch \\
\hline Annulus dia. $\left(d_{w}\right)$ & 8.25 Inch \\
\hline Screen Length (L) & 15 Feet \\
\hline \multicolumn{2}{|l|}{ Depths to: } \\
\hline water level (DTW) & 8.31 Feet \\
\hline top of screen (TOS) & 12.66 Feet \\
\hline Base of Aquifer (DTB) & 27.66 Feet \\
\hline \multicolumn{2}{|c|}{ Annular Fill: } \\
\hline \multicolumn{2}{|c|}{$\begin{array}{c}\text { across screen -- Fine Sand } \\
\text { above screen -- Bentonite }\end{array}$} \\
\hline \multicolumn{2}{|c|}{ Aquifer Material -- Fine Sand } \\
\hline \multicolumn{2}{|c|}{ COMPUTED } \\
\hline $\mathrm{L}_{\text {wetted }}$ & 15 Feet \\
\hline$D=$ & 19.35 Feet \\
\hline$H=$ & 19.35 Feet \\
\hline $\mathrm{L} / \mathrm{r}_{\mathrm{w}}=$ & 43.64 \\
\hline $\mathrm{y}_{0 \text {-DISPLACEMENT }}=$ & 0.93 Feet \\
\hline $\mathrm{y}_{0-\mathrm{SLUG}}=$ & 0.75 Feet \\
\hline \multicolumn{2}{|c|}{ From look-up table using $\mathrm{L} / \mathrm{r}_{\mathrm{w}}$} \\
\hline Fully penetrate $\mathrm{C}=$ & 2.563 \\
\hline $\ln (\operatorname{Re} / r w)=$ & 3.015 \\
\hline $\operatorname{Re}=$ & 7.01 Feet \\
\hline Slope $=$ & $0.023192 \log _{10} / \mathrm{sec}$ \\
\hline$t_{90 \%}$ recovery $=$ & $43 \mathrm{sec}$ \\
\hline \multicolumn{2}{|l|}{ Input is consistent. } \\
\hline $\begin{array}{l}\mathrm{K}= \\
\mathrm{T}=\end{array}$ & $\begin{array}{l}3.2 \text { Feet/Day } \\
62 \text { Feet2/Day }\end{array}$ \\
\hline
\end{tabular}

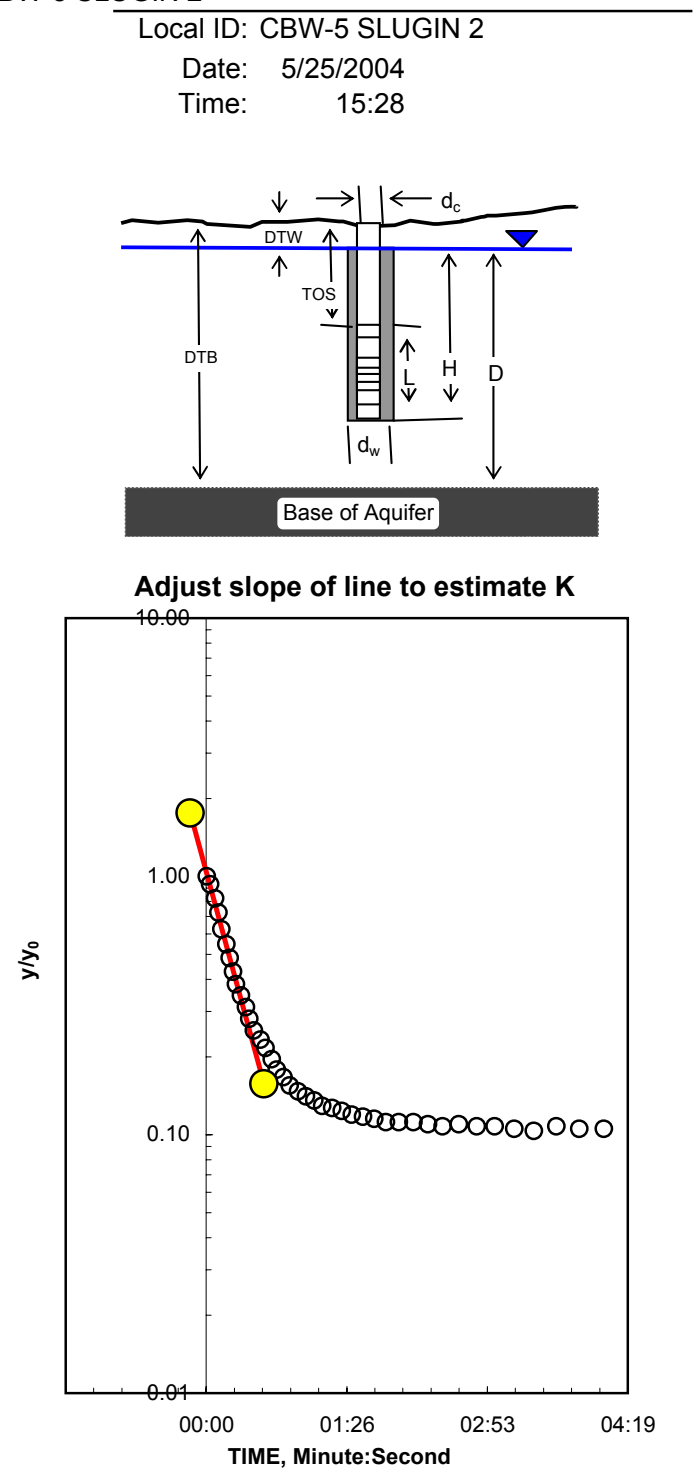

$\begin{array}{ccc} & \text { Reduced Data } & \\ & \text { Time, } & \text { Water } \\ \text { Entry } & \text { Hr:Min:Sec } & \text { Level } \\ 1 & 15: 28: 30.0 & 7.38 \\ 2 & 15: 28: 32.0 & 7.44 \\ 3 & 15: 28: 35.0 & 7.55 \\ 4 & 15: 28: 37.0 & 7.64 \\ 5 & 15: 28: 39.0 & 7.73 \\ 6 & 15: 28: 42.0 & 7.80 \\ 7 & 15: 28: 44.0 & 7.86 \\ 8 & 15: 28: 46.0 & 7.91 \\ 9 & 15: 28: 48.0 & 7.95 \\ 10 & 15: 28: 51.0 & 7.99 \\ 11 & 15: 28: 54.0 & 8.02 \\ 12 & 15: 28: 56.0 & 8.05 \\ 13 & 15: 28: 59.0 & 8.08 \\ 14 & 15: 29: 03.0 & 8.09 \\ 15 & 15: 29: 06.0 & 8.11 \\ 16 & 15: 29: 10.0 & 8.13 \\ 17 & 15: 29: 13.0 & 8.14 \\ 18 & 15: 29: 17.0 & 8.16 \\ 19 & 15: 29: 21.0 & 8.17 \\ 20 & 15: 29: 26.0 & 8.17 \\ 21 & 15: 29: 31.0 & 8.18 \\ 22 & 15: 29: 36.0 & 8.18 \\ 23 & 15: 29: 41.0 & 8.19 \\ 24 & 15: 29: 47.0 & 8.19 \\ 25 & 15: 29: 53.0 & 8.20 \\ 26 & 15: 29: 59.0 & 8.20 \\ 27 & 15: 30: 06.0 & 8.20 \\ 28 & 15: 30: 13.0 & 8.20 \\ 29 & 15: 30: 20.0 & 8.21 \\ 30 & 15: 30: 28.0 & 8.21 \\ 31 & 15: 30: 37.0 & 8.21 \\ 32 & 15: 30: 46.0 & 8.21 \\ 33 & 15: 30: 55.0 & 8.21 \\ 34 & 15: 31: 05.0 & 8.21 \\ 35 & 15: 31: 16.0 & 8.21 \\ 36 & 15: 31: 27.0 & 8.21 \\ 37 & 15: 31: 39.0 & 8.21 \\ 38 & 15: 31: 51.0 & 8.21 \\ 39 & 15: 32: 05.0 & 8.21 \\ 40 & 15: 32: 19.0 & 8.21 \\ 41 & 15: 32: 34.0 & 8.21\end{array}$

Bouwer and Rice (1976) analysis of slug test

Barrett's Farm site, well 5, slug in 2 assuming annulus dia 8.25

assuming slug $5 \mathrm{ft}$ 
Appendix 1B. Slug-test results for wells at the Barrett's Farm aquifer-test site in the Little Contentnea Creek basin, Greene County, North Carolina, 2002-03. - Continued

WELL ID: CBW-5 SLUGOUT 1

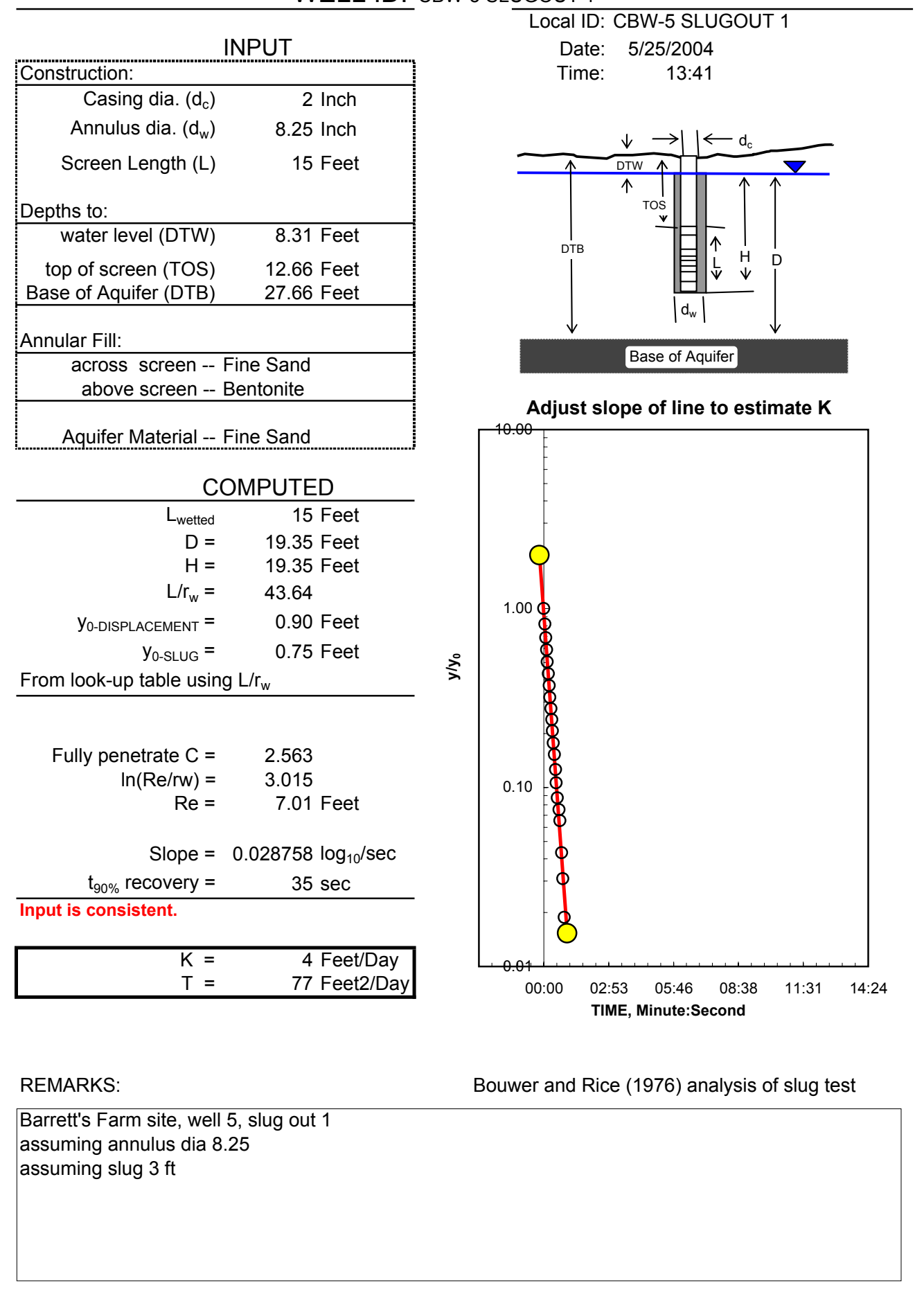

$\begin{array}{ccc} & \text { Reduced Data } & \\ & \text { Time, } & \text { Water } \\ \text { Entry } & \text { Hr:Min:Sec } & \text { Level } \\ 1 & 13: 41: 50.0 & 9.21 \\ 2 & 13: 41: 53.0 & 9.05 \\ 3 & 13: 41: 55.0 & 8.93 \\ 4 & 13: 41: 57.0 & 8.84 \\ 5 & 13: 41: 59.0 & 8.76 \\ 6 & 13: 42: 02.0 & 8.70 \\ 7 & 13: 42: 04.0 & 8.65 \\ 8 & 13: 42: 06.0 & 8.60 \\ 9 & 13: 42: 09.0 & 8.56 \\ 10 & 13: 42: 11.0 & 8.53 \\ 11 & 13: 42: 13.0 & 8.50 \\ 12 & 13: 42: 15.0 & 8.47 \\ 13 & 13: 42: 18.0 & 8.45 \\ 14 & 13: 42: 21.0 & 8.42 \\ 15 & 13: 42: 23.0 & 8.41 \\ 16 & 13: 42: 26.0 & 8.39 \\ 17 & 13: 42: 30.0 & 8.38 \\ 18 & 13: 42: 33.0 & 8.37 \\ 19 & 13: 42: 37.0 & 8.35 \\ 20 & 13: 42: 40.0 & 8.34 \\ 21 & 13: 42: 44.0 & 8.33 \\ 22 & 13: 42: 48.0 & 8.32 \\ 23 & 13: 42: 53.0 & 8.31 \\ 24 & 13: 42: 58.0 & 8.31 \\ 25 & 13: 43: 03.0 & 8.30 \\ 26 & 13: 43: 08.0 & 8.29 \\ 27 & 13: 43: 14.0 & 8.29 \\ 28 & 13: 43: 20.0 & 8.29 \\ 29 & 13: 43: 26.0 & 8.29 \\ 30 & 13: 43: 33.0 & 8.28 \\ 31 & 13: 43: 40.0 & 8.28 \\ 32 & 13: 43: 47.0 & 8.28 \\ 33 & 13: 43: 55.0 & 8.28 \\ 34 & 13: 44: 04.0 & 8.28 \\ 35 & 13: 44: 13.0 & 8.27 \\ 36 & 13: 44: 22.0 & 8.27 \\ 37 & 13: 44: 32.0 & 8.28 \\ 38 & 13: 44: 43.0 & 8.27 \\ 39 & 13: 44: 54.0 & 8.27 \\ 40 & 13: 45: 06.0 & 8.27 \\ 45 & 13: 45: 18.0 & 8.27 \\ & 13: 45: 32.0 & 8.27 \\ 13: 45: 46.0 & 8.27 \\ 13: 46: 01.0 & 8.27 \\ 13: 46: 17.0 & 8.27\end{array}$


Appendix 1C. Slug-test results for wells at the Scuffleton aquifer-test site in the Little Contentnea Creek basin, Pitt County, North Carolina, 2002-03.

WELL ID: MFW-1A Slug-Out 1

\begin{tabular}{|c|c|}
\hline & NPUT \\
\hline \multicolumn{2}{|l|}{ Construction: } \\
\hline Casing dia. $\left(\mathrm{d}_{\mathrm{c}}\right)$ & 4 Inch \\
\hline Annulus dia. $\left(\mathrm{d}_{\mathrm{w}}\right)$ & 10.25 Inch \\
\hline Screen Length (L) & 30 Feet \\
\hline \multicolumn{2}{|l|}{ Depths to: } \\
\hline water level (DTW) & 10.8 Feet \\
\hline top of screen (TOS) & 15.45 Feet \\
\hline Base of Aquifer (DTB) & 45.45 Feet \\
\hline \multicolumn{2}{|c|}{ Annular Fill: } \\
\hline \multicolumn{2}{|c|}{$\begin{array}{c}\text { across screen -- Coarse Sand } \\
\text { above screen -- Bentonite }\end{array}$} \\
\hline \multicolumn{2}{|c|}{ Aquifer Material -- Fine Sand } \\
\hline \multicolumn{2}{|c|}{ COMPUTED } \\
\hline $\mathrm{L}_{\text {wetted }}$ & 30 Feet \\
\hline$D=$ & 34.65 Feet \\
\hline$H=$ & 34.65 Feet \\
\hline $\mathrm{L} / \mathrm{r}_{\mathrm{w}}=$ & 70.24 \\
\hline $\mathrm{y}_{0-\text { DISPLACEMENT }}=$ & 0.97 Feet \\
\hline $\mathrm{y}_{0-S L U G}=$ & 1.95 Feet \\
\hline \multicolumn{2}{|c|}{ From look-up table using $\mathrm{L} / \mathrm{r}_{\mathrm{w}}$} \\
\hline Fully penetrate $C=$ & 3.391 \\
\hline $\ln (\operatorname{Re} / r w)=$ & 3.350 \\
\hline $\operatorname{Re}=$ & 12.17 Feet \\
\hline Slope $=$ & $0.021472 \log _{10} / \mathrm{sec}$ \\
\hline$t_{90 \%}$ recovery $=$ & $47 \mathrm{sec}$ \\
\hline \multicolumn{2}{|l|}{ Input is consistent. } \\
\hline $\begin{array}{l}\mathrm{K}= \\
\mathrm{T}=\end{array}$ & $\begin{array}{l}\text { 6.6 Feet/Day } \\
230 \text { Feet2/Day }\end{array}$ \\
\hline
\end{tabular}

REMARKS:

Scuffleton - MFW-1A slug out 1
Local ID: IA slug-out1

$$
\text { Date: } \quad 5 / 4 / 2004
$$$$
\text { Time: } \quad 0: 00
$$
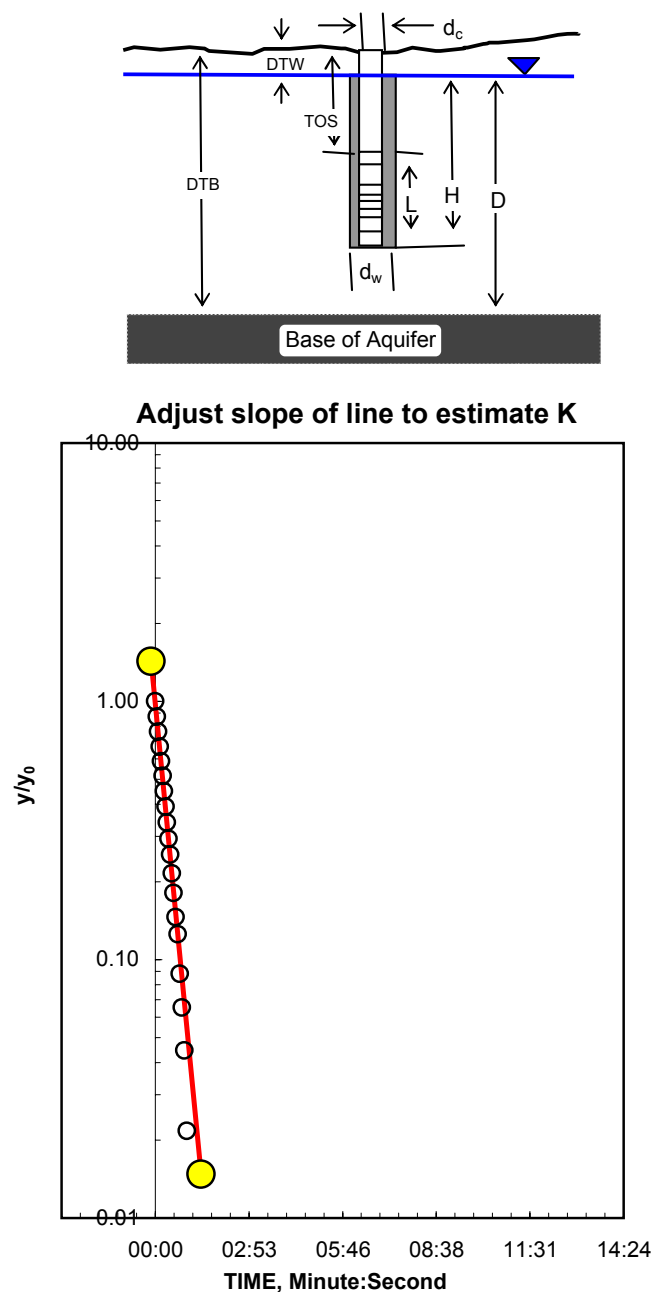

Bouwer and Rice (1976) analysis of slug test

\begin{tabular}{|c|c|c|}
\hline & Reduced Data & \\
\hline & Time, & Water \\
\hline Entry & Hr:Min:Sec & Level \\
\hline 1 & 0:00:00.0 & 11.77 \\
\hline 2 & $0: 00: 02.6$ & 11.64 \\
\hline 3 & 0:00:05.3 & 11.54 \\
\hline 4 & 0:00:07.9 & 11.45 \\
\hline 5 & 0:00:10.6 & 11.37 \\
\hline 6 & $0: 00: 13.2$ & 11.30 \\
\hline 7 & $0: 00: 15.8$ & 11.23 \\
\hline 8 & $0: 00: 18.5$ & 11.18 \\
\hline 9 & $0: 00: 21.1$ & 11.13 \\
\hline 10 & $0: 00: 24.0$ & 11.08 \\
\hline 11 & $0: 00: 27.0$ & 11.05 \\
\hline 12 & $0: 00: 30.1$ & 11.01 \\
\hline 13 & $0: 00: 33.5$ & 10.98 \\
\hline 14 & $0: 00: 37.0$ & 10.94 \\
\hline 15 & $0: 00: 40.8$ & 10.92 \\
\hline 16 & $0: 00: 44.7$ & 10.89 \\
\hline 17 & $0: 00: 49.0$ & 10.86 \\
\hline 18 & $0: 00: 53.4$ & 10.84 \\
\hline 19 & $0: 00: 58.2$ & 10.82 \\
\hline 20 & $0: 01: 03.2$ & 10.81 \\
\hline 21 & 0:01:08.5 & 10.79 \\
\hline 22 & $0: 01: 14.1$ & 10.78 \\
\hline 23 & 0:01:20.1 & 10.77 \\
\hline 24 & $0: 01: 26.4$ & 10.76 \\
\hline 25 & $0: 01: 33.1$ & 10.76 \\
\hline 26 & $0: 01: 40.2$ & 10.75 \\
\hline 27 & $0: 01: 47.7$ & 10.75 \\
\hline 28 & $0: 01: 55.7$ & 10.74 \\
\hline 29 & $0: 02: 04.1$ & 10.74 \\
\hline 30 & $0: 02: 13.0$ & 10.74 \\
\hline 31 & $0: 02: 22.5$ & 10.74 \\
\hline 32 & $0: 02: 32.5$ & 10.74 \\
\hline 33 & $0: 02: 43.1$ & 10.73 \\
\hline 34 & $0: 02: 54.3$ & 10.73 \\
\hline 35 & 0:03:06.2 & 10.73 \\
\hline 36 & $0: 03: 18.8$ & 10.73 \\
\hline 37 & $0: 03: 32.2$ & 10.73 \\
\hline 38 & $0: 03: 46.3$ & 10.73 \\
\hline 39 & 0:04:01.3 & 10.73 \\
\hline 40 & $0: 04: 17.2$ & 10.73 \\
\hline 41 & $0: 04: 34.0$ & 10.73 \\
\hline 42 & $0: 04: 51.9$ & 10.73 \\
\hline 43 & $0: 05: 10.7$ & 10.73 \\
\hline 44 & $0: 05: 30.7$ & 10.73 \\
\hline 45 & $0: 05: 51.9$ & 10.73 \\
\hline
\end{tabular}


Appendix 1C. Slug-test results for wells at the Scuffleton aquifer-test site in the Little Contentnea Creek basin, Pitt County, North Carolina, 2002-03. - Continued

WELL ID: MFW-2 Slug-Out 2

\begin{tabular}{|c|c|}
\hline \multicolumn{2}{|c|}{ INPUT } \\
\hline \multicolumn{2}{|l|}{ Construction: } \\
\hline Casing dia. $\left(\mathrm{d}_{\mathrm{c}}\right)$ & 2 Inch \\
\hline Annulus dia. $\left(\mathrm{d}_{\mathrm{w}}\right)$ & 8.25 Inch \\
\hline Screen Length (L) & 35 Feet \\
\hline \multicolumn{2}{|l|}{ Depths to: } \\
\hline water level (DTW) & 10.12 Feet \\
\hline top of screen (TOS) & 10.35 Feet \\
\hline Base of Aquifer (DTB) & 45.35 Feet \\
\hline \multicolumn{2}{|c|}{ Annular Fill: } \\
\hline \multicolumn{2}{|c|}{$\begin{array}{c}\text { across screen -- Fine Sand } \\
\text { above screen -- Bentonite }\end{array}$} \\
\hline \multicolumn{2}{|c|}{ Aquifer Material -- Fine Sand } \\
\hline \multicolumn{2}{|c|}{ COMPUTED } \\
\hline $\mathrm{L}_{\text {wetted }}$ & 35 Feet \\
\hline$D=$ & 35.23 Feet \\
\hline $\mathrm{H}=$ & 35.23 Feet \\
\hline $\mathrm{L} / \mathrm{r}_{\mathrm{w}}=$ & 101.82 \\
\hline $\mathrm{y}_{0 \text {-DISPLACEMENT }}=$ & 0.24 Feet \\
\hline $\mathrm{y}_{0-S L U G}=$ & 0.75 Feet \\
\hline From look-up table usin & \\
\hline
\end{tabular}

Fully penetrate $\mathrm{C}=\quad 4.370$ $\ln (\mathrm{Re} / \mathrm{rw})=\quad 3.565$

$\operatorname{Re}=12.15$ Feet

Slope $=0.03219 \log _{10} / \mathrm{sec}$

$t_{90 \%}$ recovery $=$ $31 \mathrm{sec}$

Input is consistent.

$\begin{array}{lr}\mathrm{K}= & 2.3 \text { Feet/Day } \\ \mathrm{T}= & 81 \text { Feet2/Day }\end{array}$
Local ID: MWF-2 Slug-Out 2

$\begin{array}{lr}\text { Date: } & 5 / 4 / 2004 \\ \text { Time: } & 0: 00\end{array}$
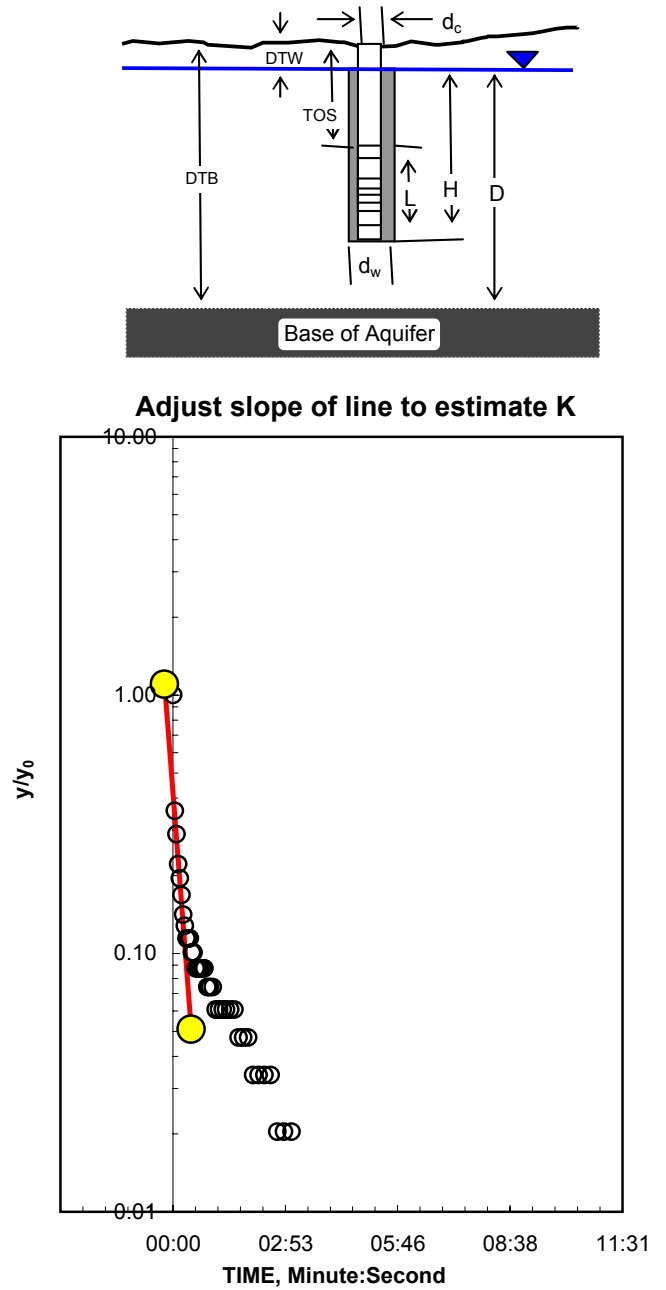

$K=2.3$ is less than likely minimum of 3 for Fine Sand REMARKS:

Bouwer and Rice (1976) analysis of slug test
Scuffleton - MFW-2 slug out 2

\begin{tabular}{|c|c|c|}
\hline \multicolumn{3}{|c|}{ Reduced Data } \\
\hline & Time, & Water \\
\hline Entry & Hr:Min:Sec & Level \\
\hline 1 & 0:00:00.0 & 10.34 \\
\hline 2 & 0:00:02.6 & 10.19 \\
\hline 3 & 0:00:05.2 & 10.17 \\
\hline 4 & 0:00:07.9 & 10.15 \\
\hline 5 & $0: 00: 10.5$ & 10.15 \\
\hline 6 & 0:00:13.1 & 10.14 \\
\hline 7 & $0: 00: 15.7$ & 10.13 \\
\hline 8 & $0: 00: 18.3$ & 10.13 \\
\hline 9 & $0: 00: 21.0$ & 10.13 \\
\hline 10 & $0: 00: 23.6$ & 10.13 \\
\hline 11 & $0: 00: 26.2$ & 10.13 \\
\hline 12 & $0: 00: 28.9$ & 10.12 \\
\hline 13 & $0: 00: 31.7$ & 10.12 \\
\hline 14 & $0: 00: 34.7$ & 10.12 \\
\hline 15 & $0: 00: 37.8$ & 10.12 \\
\hline 16 & $0: 00: 41.2$ & 10.12 \\
\hline 17 & $0: 00: 44.7$ & 10.12 \\
\hline 18 & 0:00:48.5 & 10.12 \\
\hline 19 & $0: 00: 52.5$ & 10.12 \\
\hline 20 & $0: 00: 56.7$ & 10.12 \\
\hline 21 & 0:01:01.2 & 10.12 \\
\hline 22 & 0:01:05.9 & 10.11 \\
\hline 23 & 0:01:10.9 & 10.11 \\
\hline 24 & $0: 01: 16.2$ & 10.11 \\
\hline 25 & $0: 01: 21.9$ & 10.11 \\
\hline 26 & $0: 01: 27.8$ & 10.11 \\
\hline 27 & $0: 01: 34.1$ & 10.11 \\
\hline 28 & $0: 01: 40.8$ & 10.11 \\
\hline 29 & $0: 01: 47.9$ & 10.11 \\
\hline 30 & $0: 01: 55.4$ & 10.11 \\
\hline 31 & $0: 02: 03.4$ & 10.11 \\
\hline 32 & 0:02:11.8 & 10.11 \\
\hline 33 & $0: 02: 20.7$ & 10.11 \\
\hline 34 & $0: 02: 30.2$ & 10.11 \\
\hline 35 & $0: 02: 40.2$ & 10.10 \\
\hline 36 & $0: 02: 50.8$ & 10.10 \\
\hline 37 & $0: 03: 02.0$ & 10.10 \\
\hline 38 & $0: 03: 14.0$ & 10.10 \\
\hline 39 & $0: 03: 26.6$ & 10.10 \\
\hline 40 & 0:03:39.9 & 10.10 \\
\hline 41 & $0: 03: 54.1$ & 10.10 \\
\hline 42 & 0:04:09.1 & 10.10 \\
\hline 43 & $0: 04: 24.9$ & 10.10 \\
\hline 44 & $0: 04: 41.8$ & 10.10 \\
\hline 45 & 0:04:59.6 & 10.10 \\
\hline
\end{tabular}


Appendix 1C. Slug-test results for wells at the Scuffleton aquifer-test site in the Little Contentnea Creek basin, Pitt County, North Carolina, 2002-03. - Continued

WELL ID: MFW-3 Slug-Out 1

\begin{tabular}{|c|c|}
\hline & NPUT \\
\hline \multicolumn{2}{|l|}{ Construction: } \\
\hline Casing dia. $\left(\mathrm{d}_{\mathrm{c}}\right)$ & 2 Inch \\
\hline Annulus dia. $\left(\mathrm{d}_{\mathrm{w}}\right)$ & 8.25 Inch \\
\hline Screen Length (L) & 35 Feet \\
\hline \multicolumn{2}{|l|}{ Depths to: } \\
\hline water level (DTW) & 10.1 Feet \\
\hline top of screen (TOS) & 10.2 Feet \\
\hline Base of Aquifer (DTB) & 45.2 Feet \\
\hline \multicolumn{2}{|c|}{ Annular Fill: } \\
\hline \multicolumn{2}{|c|}{$\begin{array}{c}\text { across screen -- Fine Sand } \\
\text { above screen -- Bentonite }\end{array}$} \\
\hline \multicolumn{2}{|c|}{ Aquifer Material -- Fine Sand } \\
\hline \multicolumn{2}{|c|}{ COMPUTED } \\
\hline $\mathrm{L}_{\text {wetted }}$ & 35 Feet \\
\hline$D=$ & 35.1 Feet \\
\hline$H=$ & 35.1 Feet \\
\hline $\mathrm{L} / \mathrm{r}_{\mathrm{w}}=$ & 101.82 \\
\hline $\mathrm{y}_{0 \text {-DISPLACEMENT }}=$ & 0.61 Feet \\
\hline $\mathrm{y}_{0-S L U G}=$ & 0.75 Feet \\
\hline \multicolumn{2}{|c|}{ From look-up table using $\mathrm{L} / \mathrm{r}_{\mathrm{w}}$} \\
\hline Fully penetrate $C=$ & 4.370 \\
\hline $\ln (\operatorname{Re} / r w)=$ & 3.563 \\
\hline $\operatorname{Re}=$ & 12.12 Feet \\
\hline Slope $=$ & $0.062934 \log _{10} / \mathrm{sec}$ \\
\hline$t_{90 \%}$ recovery $=$ & $16 \mathrm{sec}$ \\
\hline \multicolumn{2}{|l|}{ Input is consistent. } \\
\hline $\begin{array}{l}\mathrm{K}= \\
\mathrm{T}=\end{array}$ & $\begin{array}{l}4.4 \text { Feet/Day } \\
150 \text { Feet2/Day }\end{array}$ \\
\hline
\end{tabular}

REMARKS:

Scuffleton - MFW-3 slug out 1
Local ID: 3 slug-out 1

Date: $\quad 5 / 4 / 2004$

Time: $\quad$ 0:00
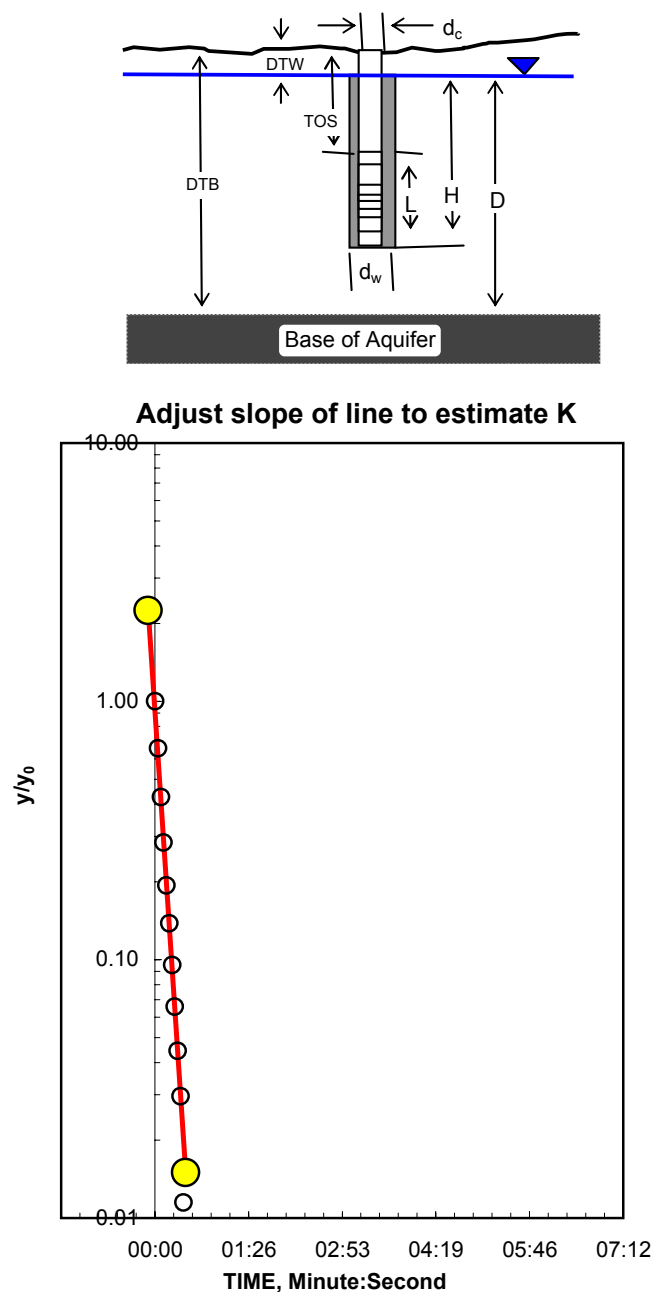

Bouwer and Rice (1976) analysis of slug test
Reduced Data Time, Water

Hr:Min:Sec Level 0:00:00.0 $\quad 10.71$

0:00:02.6 $\quad 10.50$

0:00:05.2 $\quad 10.36$

0:00:07.8 $\quad 10.27$

0:00:10.4 10.22

$0: 00: 12.9 \quad 10.18$

0:00:15.5 $\quad 10.16$

0:00:18.1 $\quad 10.14$

$0: 00: 20.7 \quad 10.13$

0:00:23.3 $\quad 10.12$

0:00:25.9 $\quad 10.11$

0:00:28.5 $\quad 10.10$

$0: 00: 31.1 \quad 10.10$

$0: 00: 33.7 \quad 10.10$

$0: 00: 36.3 \quad 10.09$

$0: 00: 38.9 \quad 10.09$

0:00:41.7 $\quad 10.09$

0:00:44.7 10.09

$0: 00: 47.9 \quad 10.09$

$0: 00: 51.2 \quad 10.09$

$0: 00: 54.8 \quad 10.08$

$0: 00: 58.5 \quad 10.09$

0:01:02.5 $\quad 10.08$

0:01:06.8 $\quad 10.08$

$0: 01: 11.2 \quad 10.08$

$0: 01: 16.0 \quad 10.08$

$0: 01: 21.0 \quad 10.08$

$0: 01: 26.3 \quad 10.08$

0:01:31.9 $\quad 10.07$

$0: 01: 37.9 \quad 10.08$

0:01:44.2 $\quad 10.07$

$0: 01: 50.9 \quad 10.07$

0:01:58.0 $\quad 10.07$

0:02:05.5 $\quad 10.07$

$0: 02: 13.4 \quad 10.07$

0:02:21.9 10.07

0:02:30.8 $\quad 10.07$

0:02:40.2 $\quad 10.07$

$0: 02: 50.3 \quad 10.07$

0:03:00.9 $\quad 10.07$

0:03:12.1 $\quad 10.07$

$0: 03: 24.0 \quad 10.07$

0:03:36.6 $\quad 10.07$

0:03:50.0 $\quad 10.07$

0:04:04.1 10.07 
Appendix 1C. Slug-test results for wells at the Scuffleton aquifer-test site in the Little Contentnea Creek basin, Pitt County, North Carolina, 2002-03. - Continued

WELL ID: MFW-4 Slug-Out 1

\begin{tabular}{|c|c|}
\hline \multicolumn{2}{|c|}{ INPUT } \\
\hline \multicolumn{2}{|l|}{ Construction: } \\
\hline Casing dia. $\left(\mathrm{d}_{\mathrm{c}}\right)$ & 2 Inch \\
\hline Annulus dia. $\left(d_{w}\right)$ & 8.25 Inch \\
\hline Screen Length (L) & 35 Feet \\
\hline \multicolumn{2}{|l|}{ Depths to: } \\
\hline water level (DTW) & 9.89 Feet \\
\hline top of screen (TOS) & 10.5 Feet \\
\hline Base of Aquifer (DTB) & 45.5 Feet \\
\hline \multicolumn{2}{|c|}{ Annular Fill: } \\
\hline \multicolumn{2}{|c|}{$\begin{array}{c}\text { across screen -- Fine Sand } \\
\text { above screen -- Bentonite }\end{array}$} \\
\hline \multicolumn{2}{|c|}{ Aquifer Material -- Fine Sand } \\
\hline \multicolumn{2}{|c|}{ COMPUTED } \\
\hline $\mathrm{L}_{\text {wetted }}$ & 35 Feet \\
\hline$D=$ & 35.61 Feet \\
\hline$H=$ & 35.61 Feet \\
\hline $\mathrm{L} / \mathrm{r}_{\mathrm{w}}=$ & 101.82 \\
\hline $\mathrm{y}_{0 \text {-DISPLACEMENT }}=$ & 0.98 Feet \\
\hline $\mathrm{y}_{0-S L U G}=$ & 0.75 Feet \\
\hline \multicolumn{2}{|c|}{ From look-up table using $\mathrm{L} / \mathrm{r}_{\mathrm{w}}$} \\
\hline Fully penetrate $\mathrm{C}=$ & 4.370 \\
\hline $\ln (\operatorname{Re} / r w)=$ & 3.572 \\
\hline $\operatorname{Re}=$ & 12.23 Feet \\
\hline Slope $=$ & $0.031816 \log _{10} / \mathrm{sec}$ \\
\hline $\mathrm{t}_{90 \%}$ recovery $=$ & $31 \mathrm{sec}$ \\
\hline \multicolumn{2}{|l|}{ Input is consistent. } \\
\hline $\begin{array}{l}\mathrm{K}= \\
\mathrm{T}=\end{array}$ & $\begin{array}{l}2.2 \text { Feet/Day } \\
78 \text { Feet2/Day }\end{array}$ \\
\hline
\end{tabular}

Local ID: MFW-4 slug-out 1

Date: $5 / 4 / 2004$

Time: $\quad 0: 00$
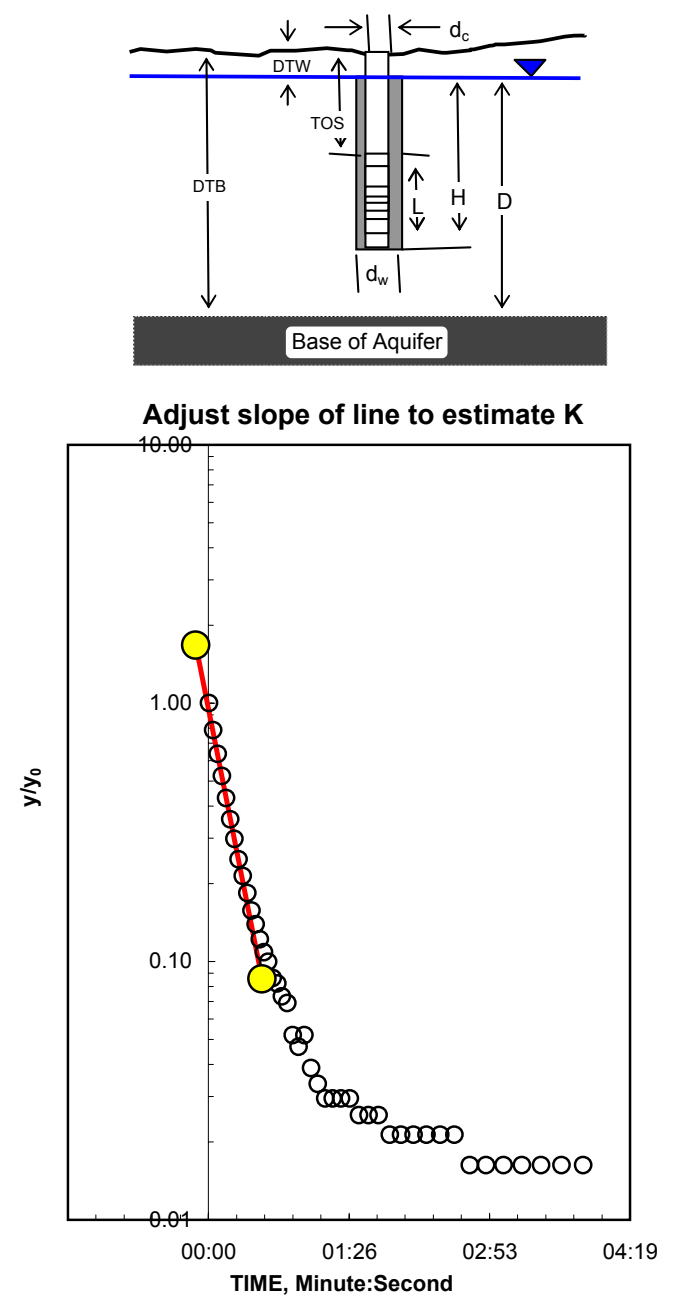

$\mathrm{K}=\mathbf{2 . 2}$ is less than likely minimum of $\mathbf{3}$ for Fine Sand REMARKS:

Bouwer and Rice (1976) analysis of slug test

$\begin{array}{ccc} & \text { Reduced Data } & \\ & \text { Time, } & \text { Water } \\ \text { Entry } & \text { Hr:Min:Sec } & \text { Level } \\ 1 & 0: 00: 00.0 & 10.88 \\ 2 & 0: 00: 02.6 & 10.66 \\ 3 & 0: 00: 05.2 & 10.52 \\ 4 & 0: 00: 07.8 & 10.40 \\ 5 & 0: 00: 10.4 & 10.31 \\ 6 & 0: 00: 13.0 & 10.24 \\ 7 & 0: 00: 15.6 & 10.18 \\ 8 & 0: 00: 18.2 & 10.14 \\ 9 & 0: 00: 20.8 & 10.10 \\ 10 & 0: 00: 23.4 & 10.07 \\ 11 & 0: 00: 26.0 & 10.05 \\ 12 & 0: 00: 28.6 & 10.03 \\ 13 & 0: 00: 31.2 & 10.01 \\ 14 & 0: 00: 33.8 & 10.00 \\ 15 & 0: 00: 36.4 & 9.99 \\ 16 & 0: 00: 39.1 & 9.98 \\ 17 & 0: 00: 41.9 & 9.97 \\ 18 & 0: 00: 44.9 & 9.96 \\ 19 & 0: 00: 48.0 & 9.96 \\ 20 & 0: 00: 51.4 & 9.94 \\ 21 & 0: 00: 54.9 & 9.94 \\ 22 & 0: 00: 58.7 & 9.94 \\ 23 & 0: 01: 02.7 & 9.93 \\ 24 & 0: 01: 06.9 & 9.92 \\ 25 & 0: 01: 11.4 & 9.92 \\ 26 & 0: 01: 16.1 & 9.92 \\ 27 & 0: 01: 21.1 & 9.92 \\ 28 & 0: 01: 26.4 & 9.92 \\ 29 & 0: 01: 32.1 & 9.92 \\ 30 & 0: 01: 38.0 & 9.92 \\ 31 & 0: 01: 44.3 & 9.92 \\ 32 & 0: 01: 51.0 & 9.91 \\ 33 & 0: 01: 58.1 & 9.91 \\ 34 & 0: 02: 05.6 & 9.91 \\ 35 & 0: 02: 13.6 & 9.91 \\ 36 & 0: 02: 22.0 & 9.91 \\ 37 & 0: 02: 30.9 & 9.91 \\ 38 & 0: 02: 40.4 & 9.91 \\ 39 & 0: 02: 50.4 & 9.91 \\ 40 & 0: 03: 01.0 & 9.91 \\ 41 & 0: 03: 12.3 & 9.91 \\ 42 & 0: 03: 24.1 & 9.91 \\ 43 & 0: 03: 36.8 & 9.91\end{array}$


Appendix 1C. Slug-test results for wells at the Scuffleton aquifer-test site in the Little Contentnea Creek basin, Pitt County, North Carolina, 2002-03. - Continued

WELL ID: MFW-5 Slug-Out 2

\begin{tabular}{|c|c|}
\hline & NPUT \\
\hline \multicolumn{2}{|l|}{ Construction: } \\
\hline Casing dia. $\left(\mathrm{d}_{\mathrm{c}}\right)$ & 2 Inch \\
\hline Annulus dia. $\left(\mathrm{d}_{\mathrm{w}}\right)$ & 8.25 Inch \\
\hline Screen Length (L) & 35 Feet \\
\hline \multicolumn{2}{|l|}{ Depths to: } \\
\hline water level (DTW) & 9.5 Feet \\
\hline top of screen (TOS) & 8.5 Feet \\
\hline Base of Aquifer (DTB) & 43.5 Feet \\
\hline \multicolumn{2}{|c|}{ Annular Fill: } \\
\hline \multicolumn{2}{|c|}{$\begin{array}{c}\text { across screen -- Fine Sand } \\
\text { above screen -- Bentonite }\end{array}$} \\
\hline \multicolumn{2}{|c|}{ Aquifer Material -- Fine Sand } \\
\hline \multicolumn{2}{|c|}{ COMPUTED } \\
\hline $\mathrm{L}_{\text {wetted }}$ & 34 Feet \\
\hline$D=$ & 34 Feet \\
\hline$H=$ & 34 Feet \\
\hline $\mathrm{L} / \mathrm{r}_{\mathrm{w}}=$ & 98.91 \\
\hline $\mathrm{y}_{0 \text {-DISPLACEMENT }}=$ & 1.04 Feet \\
\hline $\mathrm{y}_{0-\mathrm{SLUG}}=$ & 1.25 Feet \\
\hline \multicolumn{2}{|c|}{ From look-up table using $\mathrm{L} / \mathrm{r}_{\mathrm{w}}$} \\
\hline Fully penetrate $\mathrm{C}=$ & 4.257 \\
\hline $\ln (\mathrm{Re} / \mathrm{rw})=$ & 3.540 \\
\hline $\operatorname{Re}=$ & 11.85 Feet \\
\hline Slope $=$ & $0.011865 \log _{10} / \mathrm{sec}$ \\
\hline$t_{90 \%}$ recovery $=$ & $84 \mathrm{sec}$ \\
\hline \multicolumn{2}{|l|}{ Input is consistent. } \\
\hline $\begin{array}{l}\mathrm{K}= \\
\mathrm{T}=\end{array}$ & $\begin{array}{l}0.85 \text { Feet/Day } \\
29 \text { Feet2/Day }\end{array}$ \\
\hline
\end{tabular}

Local ID: .5 slug-out 2

Date: $\quad 5 / 4 / 2004$

Time: $\quad 0: 00$
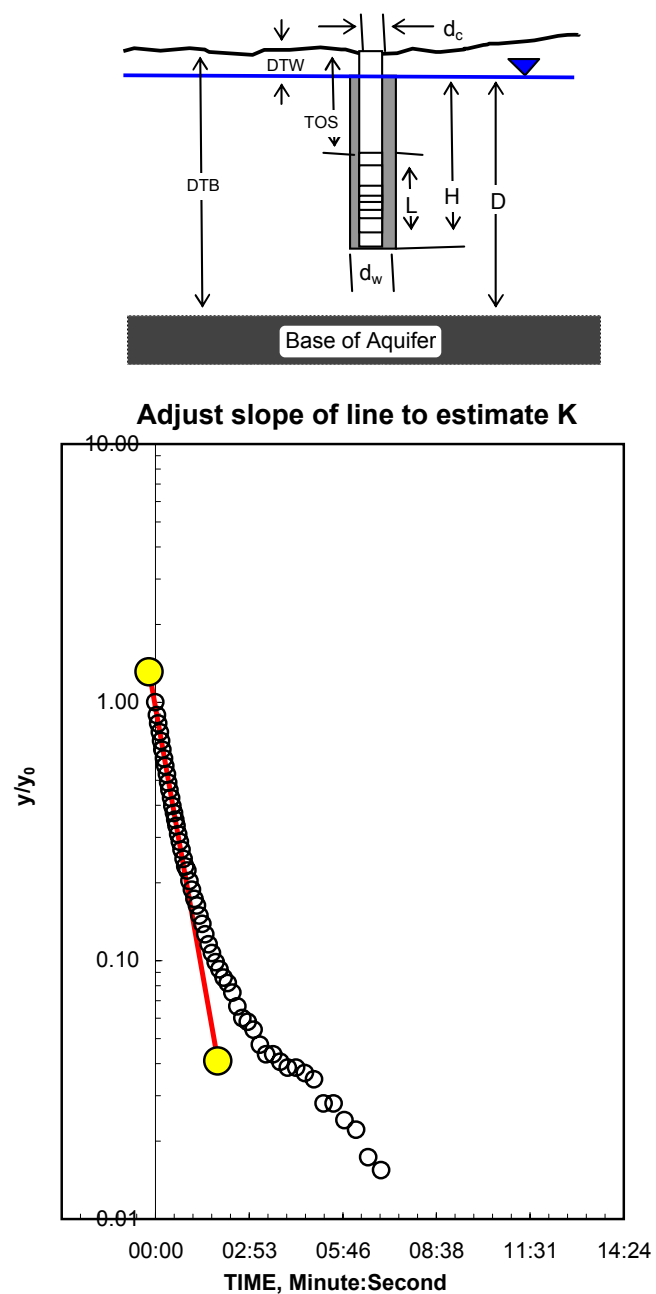

$K=\mathbf{0 . 8 5}$ is less than likely minimum of 3 for Fine Sand REMARKS: Bouwer and Rice (1976) analysis of slug test

\begin{tabular}{ccc} 
& Reduced Data & \\
& Time, & Water \\
Entry & Hr:Min:Sec & Level \\
1 & $0: 00: 00.0$ & 10.24 \\
2 & $0: 00: 02.6$ & 10.12 \\
3 & $0: 00: 05.2$ & 10.06 \\
4 & $0: 00: 07.8$ & 9.99 \\
5 & $0: 00: 10.4$ & 9.93 \\
6 & $0: 00: 13.1$ & 9.88 \\
7 & $0: 00: 15.7$ & 9.83 \\
8 & $0: 00: 18.3$ & 9.79 \\
9 & $0: 00: 20.9$ & 9.75 \\
10 & $0: 00: 23.5$ & 9.71 \\
11 & $0: 00: 26.1$ & 9.67 \\
12 & $0: 00: 28.7$ & 9.64 \\
13 & $0: 00: 31.3$ & 9.61 \\
14 & $0: 00: 33.9$ & 9.59 \\
15 & $0: 00: 36.5$ & 9.56 \\
16 & $0: 00: 39.2$ & 9.54 \\
17 & $0: 00: 42.0$ & 9.52 \\
18 & $0: 00: 45.0$ & 9.50 \\
19 & $0: 00: 48.2$ & 9.48 \\
20 & $0: 00: 51.5$ & 9.46 \\
21 & $0: 00: 55.1$ & 9.44 \\
22 & $0: 00: 58.8$ & 9.43 \\
23 & $0: 01: 02.8$ & 9.41 \\
24 & $0: 01: 07.0$ & 9.40 \\
25 & $0: 01: 11.5$ & 9.38 \\
26 & $0: 01: 16.2$ & 9.37 \\
27 & $0: 01: 21.3$ & 9.36 \\
28 & $0: 01: 26.6$ & 9.34 \\
29 & $0: 01: 32.2$ & 9.33 \\
30 & $0: 01: 38.2$ & 9.32 \\
31 & $0: 01: 44.5$ & 9.31 \\
32 & $0: 01: 51.2$ & 9.30 \\
33 & $0: 01: 58.3$ & 9.30 \\
34 & $0: 02: 05.8$ & 9.29 \\
35 & $0: 02: 13.7$ & 9.29 \\
36 & $0: 02: 22.2$ & 9.28 \\
37 & $0: 02: 31.1$ & 9.27 \\
38 & $0: 02: 40.5$ & 9.26 \\
39 & $0: 02: 50.5$ & 9.26 \\
40 & $0: 03: 01.2$ & 9.26 \\
41 & $0: 03: 12.4$ & 9.25 \\
43 & $0: 03: 24.3$ & 9.25 \\
$0: 03: 36.9$ & 9.25 \\
& $0: 03: 50.3$ & 9.24 \\
$0: 04: 04.4$ & 9.24 \\
\hline 3 & &
\end{tabular}


Appendix 1D. Slug-test results for wells at the Ballards Crossroads aquifer-test site in the Little Contentnea Creek basin, Pitt County, North Carolina, 2002-03.

WELL ID: Ballard's Crossroads well BCW-1 slug in \#1

\begin{tabular}{|c|c|}
\hline & VPUT \\
\hline \multicolumn{2}{|l|}{ Construction: } \\
\hline Casing dia. $\left(\mathrm{d}_{\mathrm{c}}\right)$ & 2 Inch \\
\hline Annulus dia. $\left(\mathrm{d}_{\mathrm{w}}\right)$ & 8.5 Inch \\
\hline Screen Length (L) & 10 Feet \\
\hline \multicolumn{2}{|l|}{ Depths to: } \\
\hline water level (DTW) & 4.43 Feet \\
\hline top of screen (TOS) & $\begin{array}{r}8 \text { Feet } \\
18 \text { Feet }\end{array}$ \\
\hline \multicolumn{2}{|c|}{ Annular Fill: } \\
\hline \multicolumn{2}{|c|}{$\begin{array}{c}\text { across screen -- Fine Sand } \\
\text { above screen -- Bentonite }\end{array}$} \\
\hline \multicolumn{2}{|c|}{ Aquifer Material -- Fine Sand } \\
\hline \multicolumn{2}{|c|}{ COMPUTED } \\
\hline $\mathrm{L}_{\text {wetted }}$ & 10 Feet \\
\hline$D=$ & 13.57 Feet \\
\hline$H=$ & 13.57 Feet \\
\hline $\mathrm{L} / \mathrm{r}_{\mathrm{w}}=$ & 28.24 \\
\hline $\mathrm{y}_{0 \text {-DISPLACEMENT }}=$ & 1.08 Feet \\
\hline $\mathrm{y}_{0-S L U G}=$ & 1.25 Feet \\
\hline \multicolumn{2}{|c|}{ From look-up table using $\mathrm{L} / \mathrm{r}_{\mathrm{w}}$} \\
\hline Fully penetrate $C=$ & 2.010 \\
\hline $\ln (\operatorname{Re} / r w)=$ & 2.682 \\
\hline $\operatorname{Re}=$ & 5.17 Feet \\
\hline Slope $=$ & $0.030594 \log _{10} / \mathrm{sec}$ \\
\hline$t_{90 \%}$ recovery $=$ & $33 \mathrm{sec}$ \\
\hline \multicolumn{2}{|l|}{ Input is consistent. } \\
\hline $\mathrm{K}=$ & 6 Feet/Day \\
\hline
\end{tabular}

REMARKS:

Slug in test \#1. DGS/BAH
Reduced Data Time, Water ocal ID: $\quad$ BCW-1 Date: $11 / 4 / 2003$ Time: $\quad$ 10:44

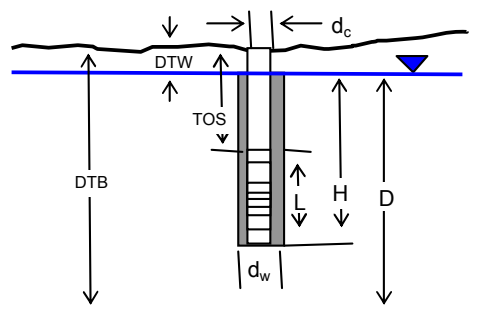

Base of Aquifer

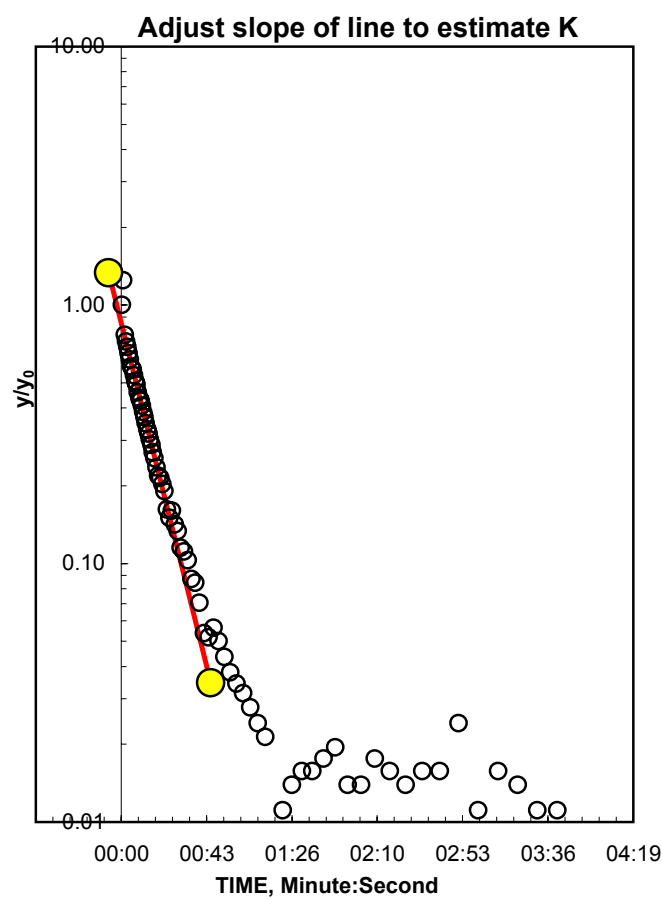

Bouwer and Rice (1976) analysis of slug test
Hr:Min:Sec Level

0:00:00.4 $\quad 3.35$

$0: 00: 01.1 \quad 3.08$

$0: 00: 01.8 \quad 3.60$

$0: 00: 02.5 \quad 3.65$

$0: 00: 03.1 \quad 3.69$

0:00:03.8 $\quad 3.73$

$0: 00: 04.5 \quad 3.77$

$0: 00: 05.1 \quad 3.81$

0:00:05.8 3.82

$0: 00: 06.5 \quad 3.85$

$0: 00: 07.1 \quad 3.88$

0:00:07.8 $\quad 3.90$

0:00:08.5 3.93

0:00:09.2 $\quad 3.96$

0:00:09.8 $\quad 3.97$

$0: 00: 10.5 \quad 3.99$

0:00:11.2 $\quad 4.01$

$0: 00: 11.8 \quad 4.03$

$0: 00: 12.5 \quad 4.05$

$0: 00: 13.2 \quad 4.07$

$0: 00: 13.8 \quad 4.09$

$0: 00: 14.5 \quad 4.10$

0:00:15.3 $\quad 4.12$

$0: 00: 16.1 \quad 4.14$

$0: 00: 16.9 \quad 4.15$

$0: 00: 17.8 \quad 4.18$

$0: 00: 18.8 \quad 4.19$

$0: 00: 19.8 \quad 4.20$

$0: 00: 20.8 \quad 4.21$

$0: 00: 21.9 \quad 4.22$

$0: 00: 23.1 \quad 4.26$

$0: 00: 24.4 \quad 4.27$

$0: 00: 25.7 \quad 4.26$

$0: 00: 27.1 \quad 4.28$

$0: 00: 28.6 \quad 4.29$

$0: 00: 30.2 \quad 4.31$

$0: 00: 31.9 \quad 4.31$

$0: 00: 33.7 \quad 4.32$

$0: 00: 35.5 \quad 4.34$

$0: 00: 37.5 \quad 4.34$

$0: 00: 39.6 \quad 4.35$

$0: 00: 41.9 \quad 4.37$

$0: 00: 44.2 \quad 4.37$

$0: 00: 46.8 \quad 4.37$

$0: 00: 49.4 \quad 4.38$ 
Appendix 1D. Slug-test results for wells at the Ballards Crossroads aquifer-test site in the Little Contentnea Creek basin, Pitt County, North Carolina, 2002-03. - Continued

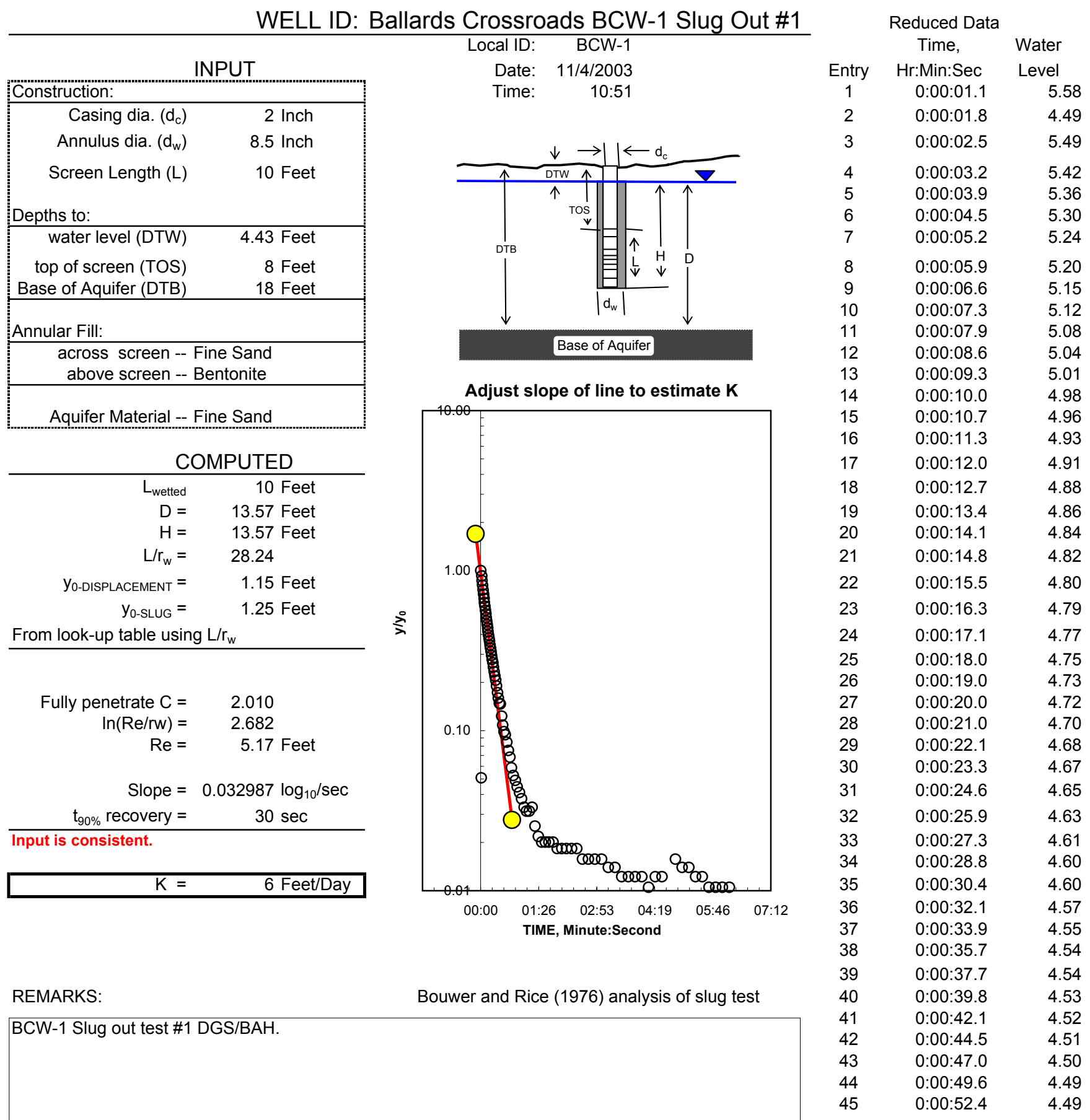


Appendix 1D. Slug-test results for wells at the Ballards Crossroads aquifer-test site in the Little Contentnea Creek basin, Pitt County, North Carolina, 2002-03. - Continued

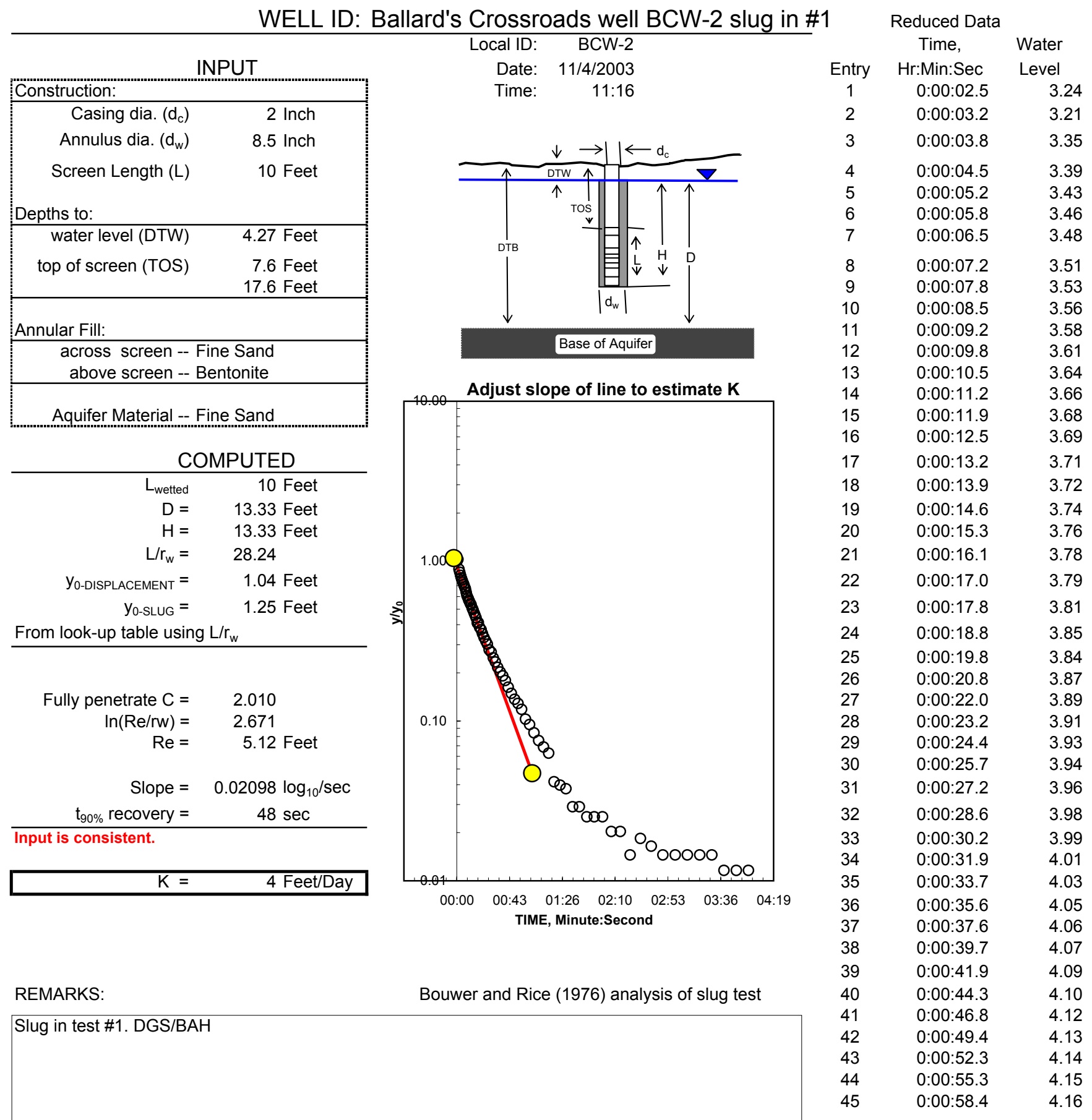


Appendix 1D. Slug-test results for wells at the Ballards Crossroads aquifer-test site in the Little Contentnea Creek basin, Pitt County, North Carolina, 2002-03. _ Continued

WELL ID: Ballard's Crossroads well BCW-2 slug out \#1

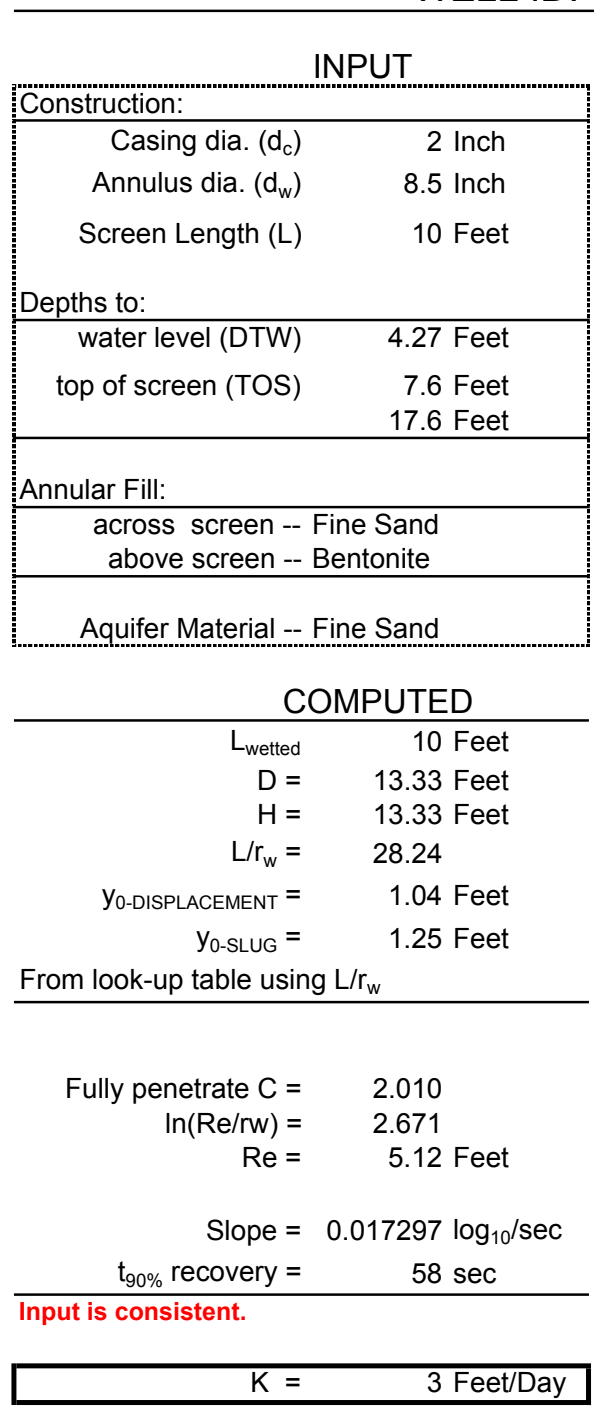

REMARKS:

Slug out test \#1. DGS/BAH $\begin{array}{rr}\text { Local ID: } & \text { BCW-2 } \\ \text { Date: } & 11 / 4 / 2003\end{array}$

Time: $\quad 11: 25$
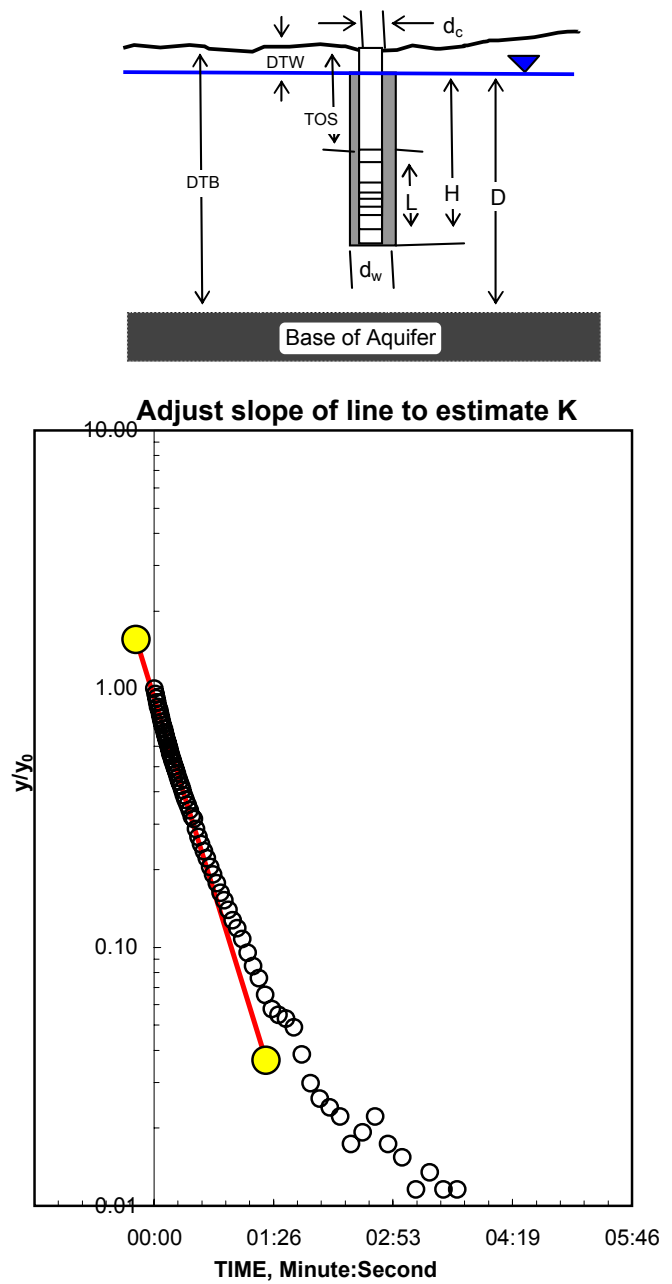

Bouwer and Rice (1976) analysis of slug test
Reduced Data

Time, Water

Hr:Min:Sec Level

$1 \quad 0: 00: 01.8 \quad 5.31$

$2 \quad 0: 00: 02.5 \quad 5.26$

$3 \quad 0: 00: 03.2 \quad 5.23$

$4 \quad 0: 00: 03.8 \quad 5.19$

$5 \quad 0: 00: 04.5 \quad 5.16$

$6 \quad 0: 00: 05.2 \quad 5.13$

$7 \quad 0: 00: 05.8 \quad 5.10$

$8 \quad 0: 00: 06.5 \quad 5.07$

$9 \quad 0: 00: 07.2 \quad 5.04$

$10 \quad 0: 00: 07.8 \quad 5.02$

$11 \quad 0: 00: 08.5 \quad 5.00$

$12 \quad 0: 00: 09.2 \quad 4.97$

$13 \quad 0: 00: 09.9 \quad 4.95$

$14 \quad 0: 00: 10.5 \quad 4.94$

$15 \quad 0: 00: 11.2 \quad 4.91$

$16 \quad 0: 00: 11.9 \quad 4.90$

$17 \quad 0: 00: 12.5 \quad 4.88$

$18 \quad 0: 00: 13.2 \quad 4.86$

$19 \quad 0: 00: 13.9 \quad 4.84$

$20 \quad 0: 00: 14.6 \quad 4.83$

$21 \quad 0: 00: 15.3 \quad 4.81$

$22 \quad 0: 00: 16.1 \quad 4.79$

$23 \quad 0: 00: 17.0 \quad 4.78$

$24 \quad 0: 00: 17.8 \quad 4.76$

$25 \quad 0: 00: 18.8 \quad 4.74$

$26 \quad 0: 00: 19.8 \quad 4.73$

$27 \quad 0: 00: 20.8 \quad 4.71$

$28 \quad 0: 00: 22.0 \quad 4.69$

$29 \quad 0: 00: 23.2 \quad 4.67$

$30 \quad 0: 00: 24.4 \quad 4.66$

$31 \quad 0: 00: 25.7 \quad 4.64$

$32 \quad 0: 00: 27.2 \quad 4.62$

$33 \quad 0: 00: 28.6 \quad 4.60$

$34 \quad 0: 00: 30.2 \quad 4.60$

$35 \quad 0: 00: 31.9 \quad 4.57$

$36 \quad 0: 00: 33.7 \quad 4.55$

$37 \quad 0: 00: 35.6 \quad 4.53$

$38 \quad 0: 00: 37.6 \quad 4.52$

$39 \quad 0: 00: 39.7 \quad 4.50$

$40 \quad 0: 00: 41.9 \quad 4.48$

$41 \quad 0: 00: 44.3 \quad 4.47$

$42 \quad 0: 00: 46.8 \quad 4.45$

$43 \quad 0: 00: 49.4 \quad 4.44$

$44 \quad 0: 00: 52.3 \quad 4.43$

$45 \quad 0: 00: 55.3 \quad 4.42$ 
Appendix 1D. Slug-test results for wells at the Ballards Crossroads aquifer-test site in the Little Contentnea Creek basin, Pitt County, North Carolina, 2002-03. - Continued

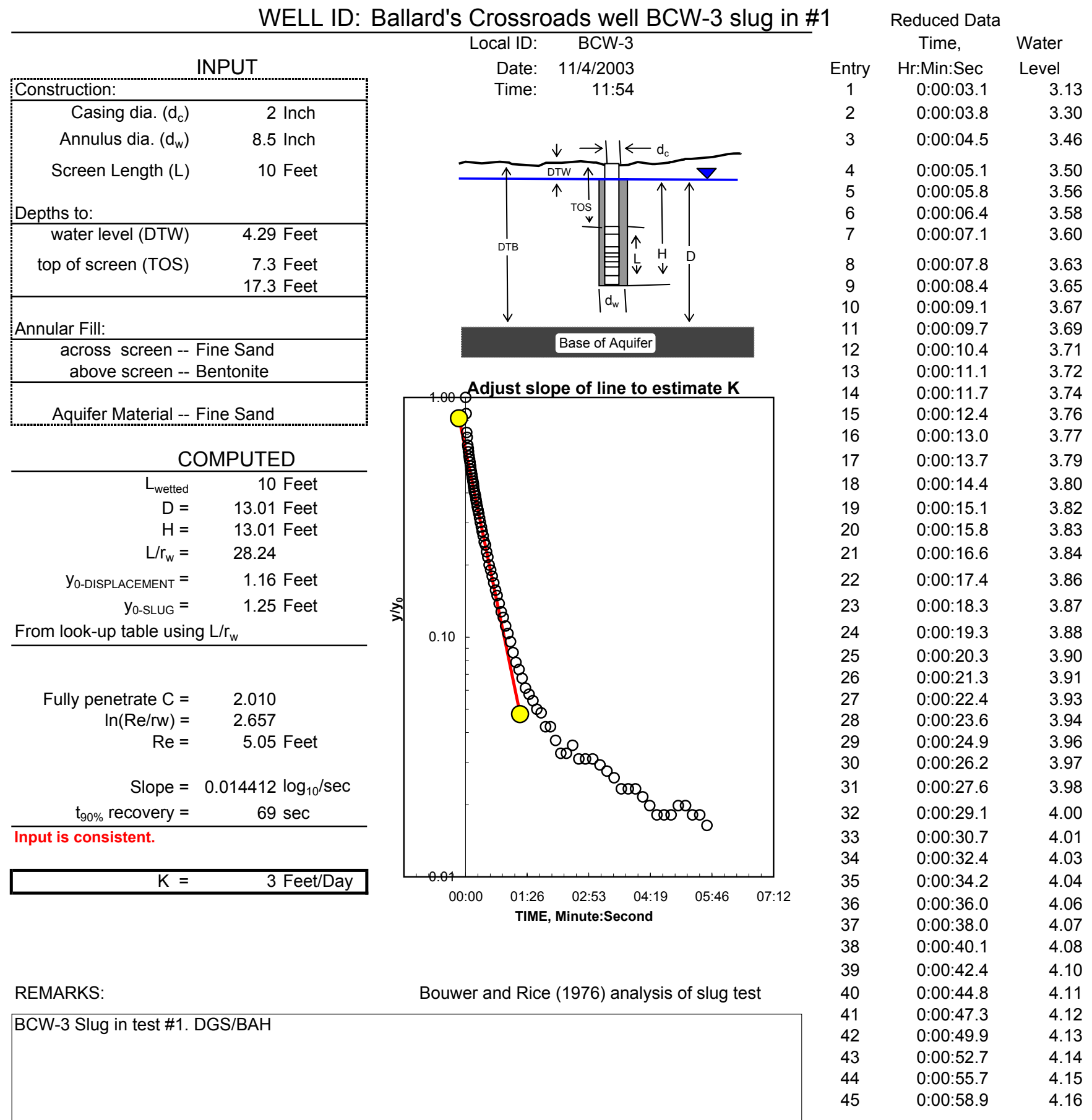


Appendix 1D. Slug-test results for wells at the Ballards Crossroads aquifer-test site in the Little Contentnea Creek basin, Pitt County, North Carolina, 2002-03. _ Continued

WELL ID: Ballard's Crossroads well BCW-3 slug out \#1

\begin{tabular}{|c|c|}
\hline \multicolumn{2}{|c|}{ INPUT } \\
\hline \multicolumn{2}{|l|}{ Construction: } \\
\hline Casing dia. $\left(\mathrm{d}_{\mathrm{c}}\right)$ & 2 Inch \\
\hline Annulus dia. $\left(\mathrm{d}_{\mathrm{w}}\right)$ & 8.5 Inch \\
\hline Screen Length (L) & 10 Feet \\
\hline \multicolumn{2}{|l|}{ Depths to: } \\
\hline water level (DTW) & 4.29 Feet \\
\hline top of screen (TOS) & $\begin{array}{l}\text { 7.3 Feet } \\
17.3 \text { Feet }\end{array}$ \\
\hline \multicolumn{2}{|l|}{ Annular Fill: } \\
\hline \multicolumn{2}{|c|}{$\begin{array}{c}\text { across screen -- Fine Sand } \\
\text { above screen -- Bentonite }\end{array}$} \\
\hline \multicolumn{2}{|c|}{ Aquifer Material -- Fine Sand } \\
\hline \multicolumn{2}{|c|}{ COMPUTED } \\
\hline $\mathrm{L}_{\text {wetted }}$ & 10 Feet \\
\hline $\begin{array}{l}D= \\
H=\end{array}$ & $\begin{array}{l}13.01 \text { Feet } \\
13.01 \text { Feet }\end{array}$ \\
\hline $\mathrm{L} / \mathrm{r}_{\mathrm{w}}=$ & 28.24 \\
\hline $\mathrm{y}_{0-\text { DISPLACEMENT }}=$ & 0.97 Feet \\
\hline $\mathrm{y}_{0-S L U G}=$ & 1.25 Feet \\
\hline From look-up table using & \\
\hline
\end{tabular}

Fully penetrate $C=\quad 2.010$

$\ln (\mathrm{Re} / \mathrm{rw})=2.657$

$\mathrm{Re}=\quad 5.05$ Feet

Slope $=0.015021 \log _{10} / \mathrm{sec}$

$t_{90 \%}$ recovery $=$

$67 \mathrm{sec}$

Input is consistent.

$\mathrm{K}=$

3 Feet/Day

REMARKS:

Bouwer and Rice (1976) analysis of slug test

Local ID: $\quad$ BCW-3

Date: $11 / 4 / 2003$

Time: $\quad 12: 01$

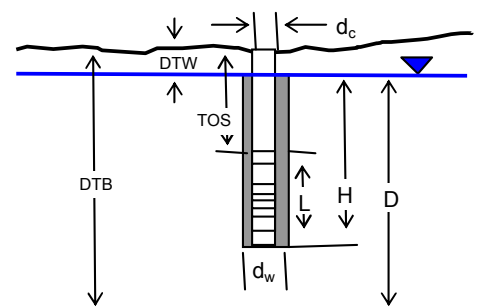

Base of Aquifer

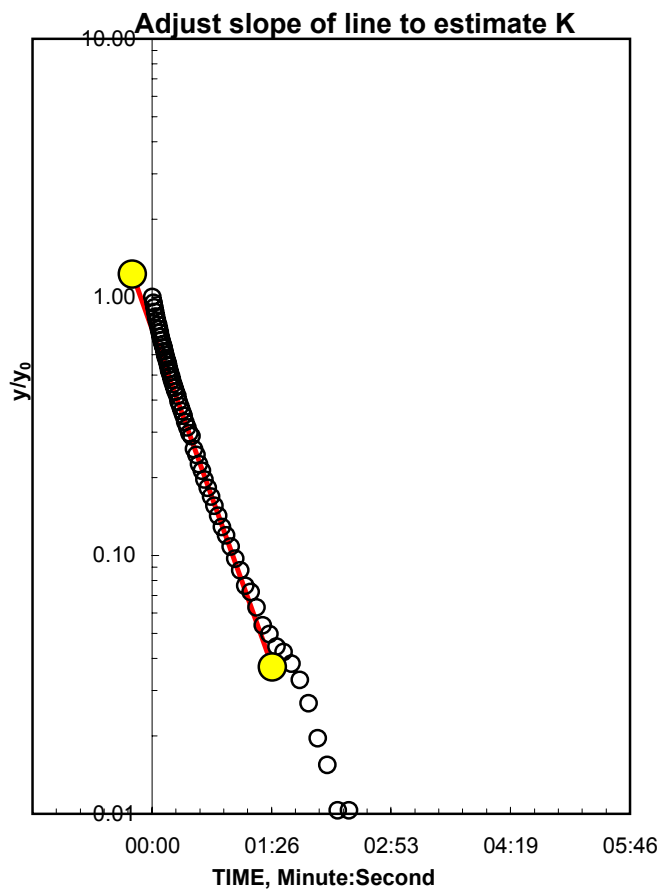

BCW-3 Slug out test \#1. DGS/BAH
Reduced Data

Time, Water

Entry Hr:Min:Sec Level

$1 \quad 0: 00: 02.5 \quad 5.26$

$2 \quad 0: 00: 03.1 \quad 5.21$

$3 \quad 0: 00: 03.8 \quad 5.17$

$4 \quad 0: 00: 04.5 \quad 5.14$

$5 \quad 0: 00: 05.1 \quad 5.11$

$6 \quad 0: 00: 05.8 \quad 5.08$

$7 \quad 0: 00: 06.4 \quad 5.05$

$8 \quad 0: 00: 07.1 \quad 5.02$

$9 \quad 0: 00: 07.8 \quad 5.00$

$10 \quad 0: 00: 08.4 \quad 4.97$

$11 \quad 0: 00: 09.1 \quad 4.95$

$12 \quad 0: 00: 09.7 \quad 4.93$

$13 \quad 0: 00: 10.4 \quad 4.91$

$14 \quad 0: 00: 11.1 \quad 4.89$

$15 \quad 0: 00: 11.7 \quad 4.87$

$16 \quad 0: 00: 12.4 \quad 4.85$

$17 \quad 0: 00: 13.0 \quad 4.83$

$18 \quad 0: 00: 13.7 \quad 4.82$

$19 \quad 0: 00: 14.4 \quad 4.80$

$20 \quad 0: 00: 15.1 \quad 4.79$

$21 \quad 0: 00: 15.8 \quad 4.77$

$22 \quad 0: 00: 16.6 \quad 4.75$

$23 \quad 0: 00: 17.4 \quad 4.74$

$24 \quad 0: 00: 18.3 \quad 4.72$

$25 \quad 0: 00: 19.3 \quad 4.71$

$26 \quad 0: 00: 20.3 \quad 4.69$

$27 \quad 0: 00: 21.3 \quad 4.67$

$28 \quad 0: 00: 22.4 \quad 4.66$

$29 \quad 0: 00: 23.6 \quad 4.64$

$30 \quad 0: 00: 24.9 \quad 4.63$

$31 \quad 0: 00: 26.2 \quad 4.61$

$32 \quad 0: 00: 27.6 \quad 4.59$

$33 \quad 0: 00: 29.1 \quad 4.58$

$34 \quad 0: 00: 30.7 \quad 4.57$

$35 \quad 0: 00: 32.4 \quad 4.54$

$36 \quad 0: 00: 34.2 \quad 4.53$

$37 \quad 0: 00: 36.1 \quad 4.51$

$38 \quad 0: 00: 38.0 \quad 4.50$

$39 \quad 0: 00: 40.1 \quad 4.48$

$40 \quad 0: 00: 42.4 \quad 4.47$

$41 \quad 0: 00: 44.8 \quad 4.45$

$42 \quad 0: 00: 47.3 \quad 4.44$

$43 \quad 0: 00: 49.9 \quad 4.43$

$44 \quad 0: 00: 52.7 \quad 4.42$

$45 \quad 0: 00: 55.7 \quad 4.41$ 
Appendix 1D. Slug-test results for wells at the Ballards Crossroads aquifer-test site in the Little Contentnea Creek basin, Pitt County, North Carolina, 2002-03. - Continued

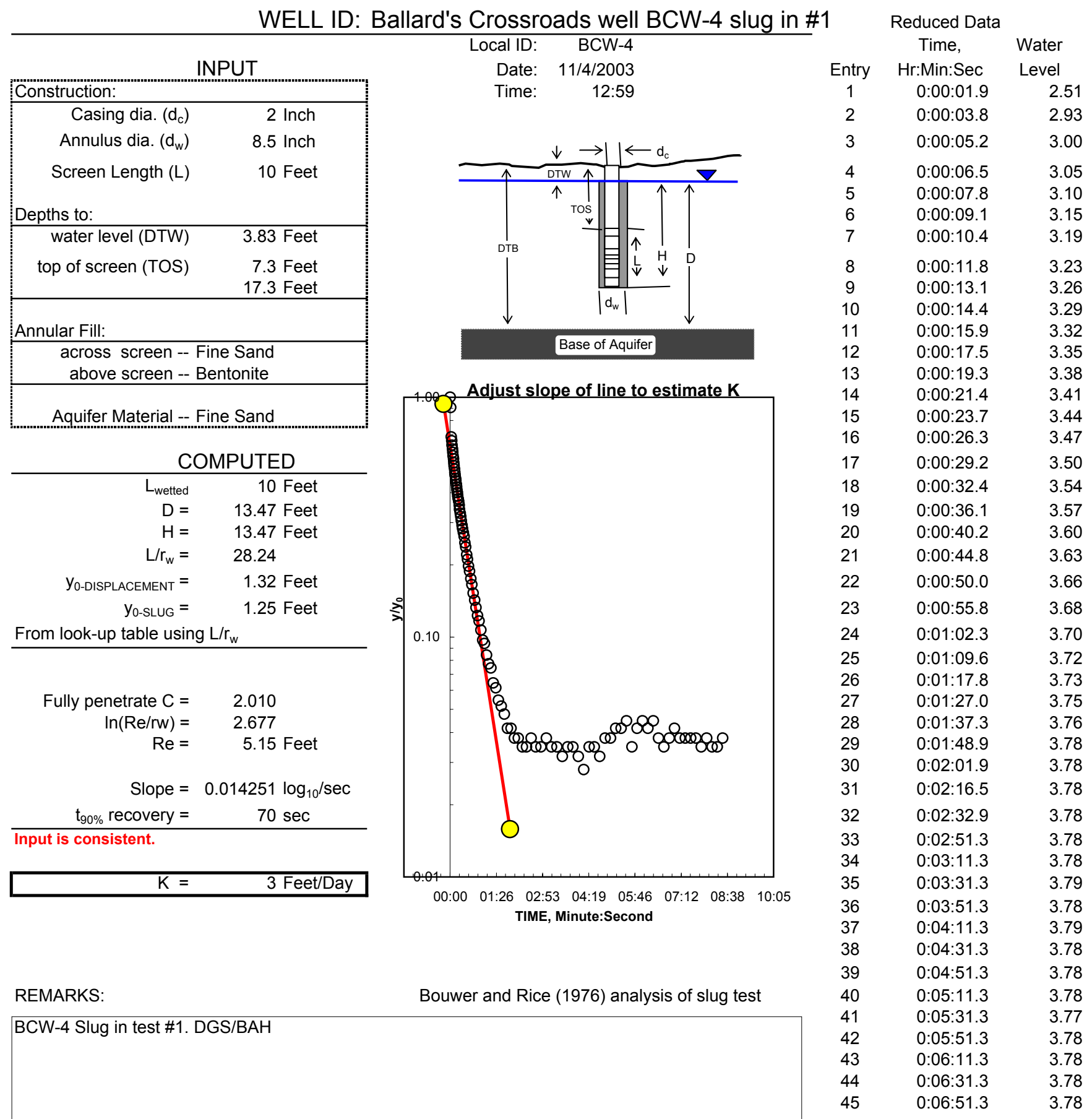


Appendix 1D. Slug-test results for wells at the Ballards Crossroads aquifer-test site in the Little Contentnea Creek basin, Pitt County, North Carolina, 2002-03. _ Continued

WELL ID: Ballard's Crossroads well BCW-4 slug out 1

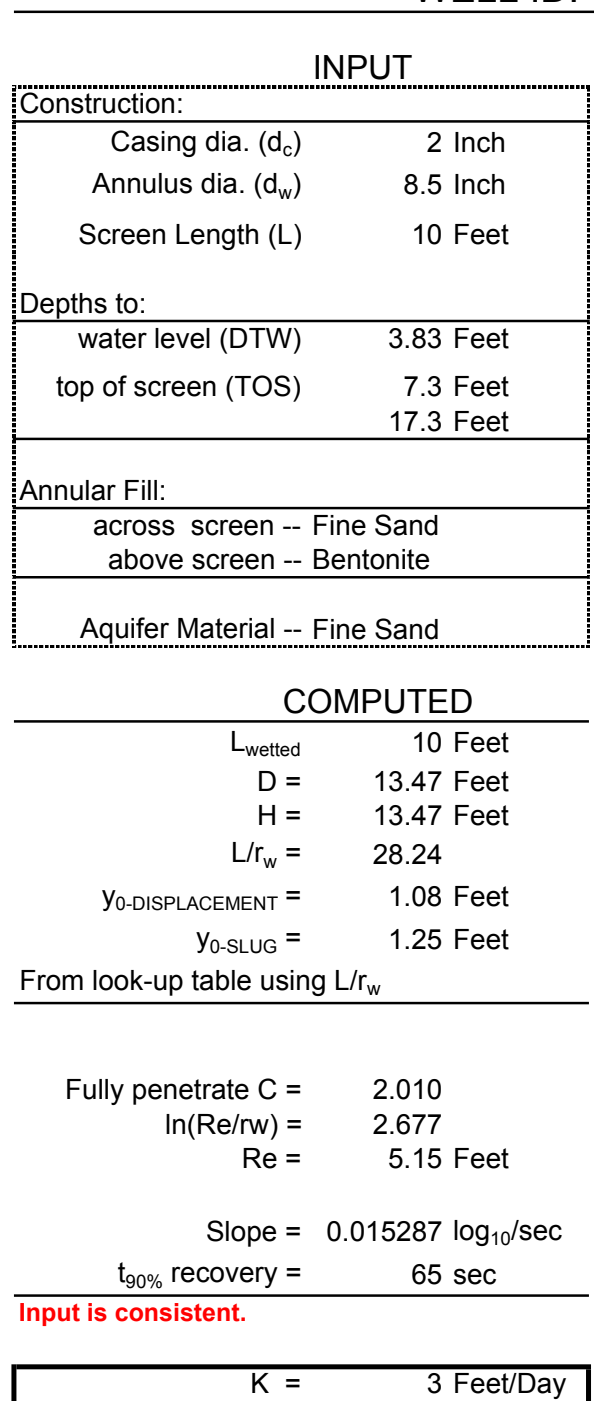

REMARKS:
Bouwer and Rice (1976) analysis of slug test

Local ID: BCW-4

Date: $11 / 4 / 2003$

Time: 13:11:00 PM
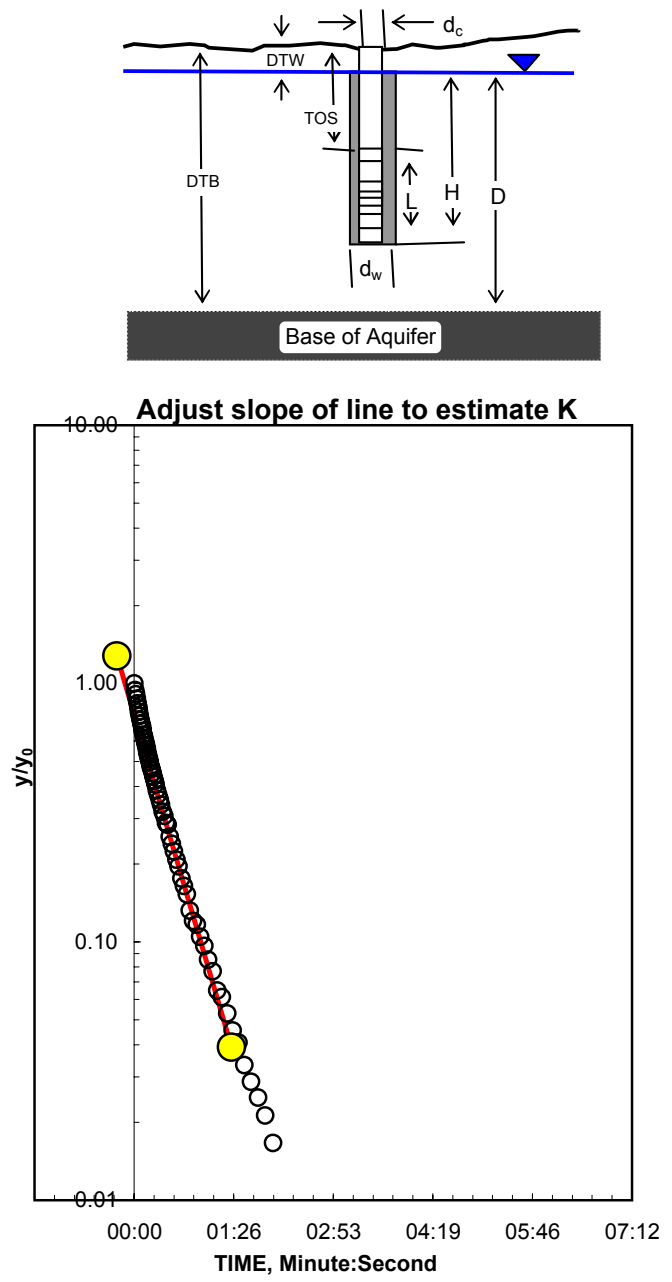

BCW-4 Slug out test \#1. DGS/BAH
Reduced Data

Time, Water

\begin{tabular}{ccc} 
Entry & Hr:Min:Sec & \multicolumn{1}{c}{ Level } \\
1 & $0: 00: 01.9$ & 4.91
\end{tabular}

$2 \quad 0: 00: 02.5 \quad 4.85$

$3 \quad 0: 00: 03.2 \quad 4.81$

$4 \quad 0: 00: 03.8 \quad 4.77$

$5 \quad 0: 00: 04.5 \quad 4.73$

$6 \quad 0: 00: 05.2 \quad 4.70$

$7 \quad 0: 00: 05.8 \quad 4.67$

$8 \quad 0: 00: 06.5 \quad 4.64$

$9 \quad 0: 00: 07.1 \quad 4.61$

$\begin{array}{ccc}9 & 0.00: 07.1 & 4.61 \\ 10 & 0: 00: 07.8 & 4.58\end{array}$

$11 \quad 0: 00: 08.5 \quad 4.56$

$12 \quad 0: 00: 09.1 \quad 4.54$

$13 \quad 0: 00: 09.8 \quad 4.52$

$14 \quad 0: 00: 10.4 \quad 4.49$

$15 \quad 0: 00: 11.1 \quad 4.47$

$16 \quad 0: 00: 11.8 \quad 4.46$

$17 \quad 0: 00: 12.4 \quad 4.43$

$18 \quad 0: 00: 13.1 \quad 4.42$

$19 \quad 0: 00: 13.7 \quad 4.40$

$20 \quad 0: 00: 14.4 \quad 4.38$

$21 \quad 0: 00: 15.1 \quad 4.37$

$22 \quad 0: 00: 15.9 \quad 4.35$

$23 \quad 0: 00: 16.6 \quad 4.33$

$24 \quad 0: 00: 17.5 \quad 4.32$

$25 \quad 0: 00: 18.4 \quad 4.30$

$26 \quad 0: 00: 19.3 \quad 4.28$

$27 \quad 0: 00: 20.3 \quad 4.27$

$28 \quad 0: 00: 21.4 \quad 4.25$

$29 \quad 0: 00: 22.5 \quad 4.23$

$30 \quad 0: 00: 23.7 \quad 4.21$

$31 \quad 0: 00: 25.0 \quad 4.20$

$32 \quad 0: 00: 26.3 \quad 4.18$

$33 \quad 0: 00: 27.7 \quad 4.16$

$34 \quad 0: 00: 29.2 \quad 4.14$

$35 \quad 0: 00: 30.8 \quad 4.14$

$36 \quad 0: 00: 32.4 \quad 4.11$

$37 \quad 0: 00: 34.2 \quad 4.09$

$38 \quad 0: 00: 36.1 \quad 4.07$

$39 \quad 0: 00: 38.1 \quad 4.06$

$40 \quad 0: 00: 40.2 \quad 4.04$

$41 \quad 0: 00: 42.4 \quad 4.02$

$42 \quad 0: 00: 44.8 \quad 4.01$

$43 \quad 0: 00: 47.3 \quad 4.00$

$44 \quad 0: 00: 50.0 \quad 3.97$

$45 \quad 0: 00: 52.8 \quad 3.96$ 
Appendix 1D. Slug-test results for wells at the Ballards Crossroads aquifer-test site in the Little Contentnea Creek basin, Pitt County, North Carolina, 2002-03. _ Continued

WELL ID: Ballard's Crossroads well BCW-5A slug in1

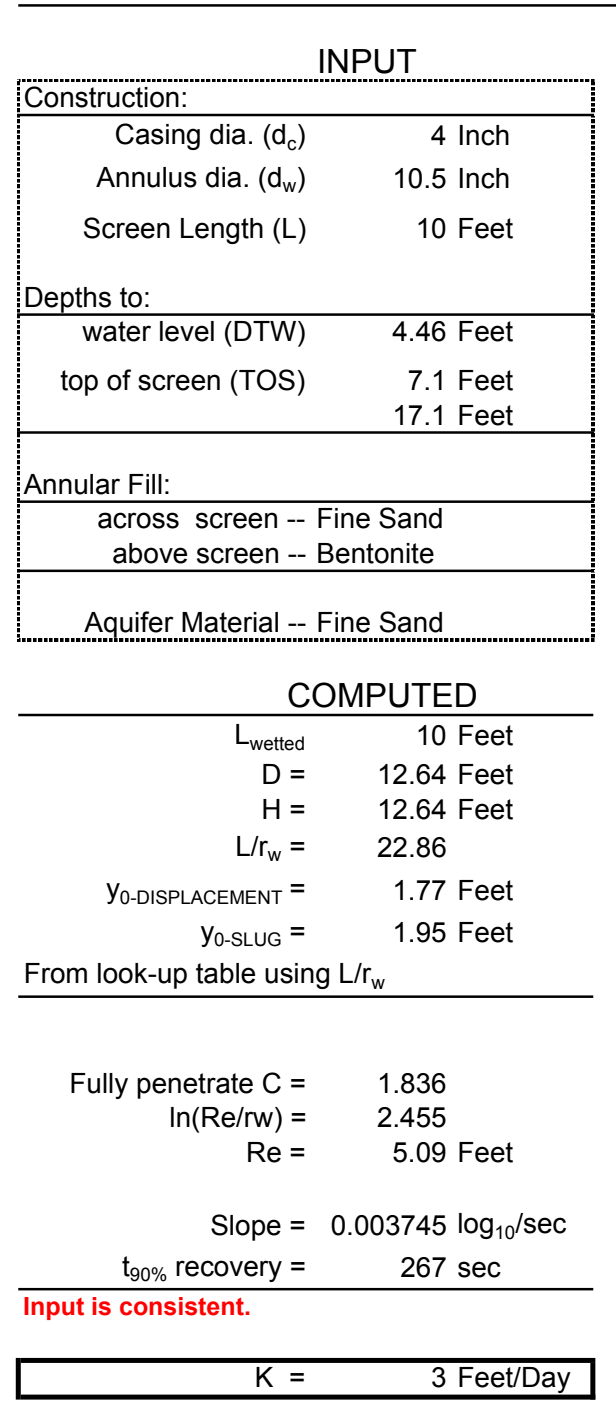

REMARKS:

Bouwer and Rice (1976) analysis of slug test

Local ID: $\mathrm{BCW}-5 \mathrm{~A}$

Date: $11 / 4 / 2003$

Time: 14:43:00 PM

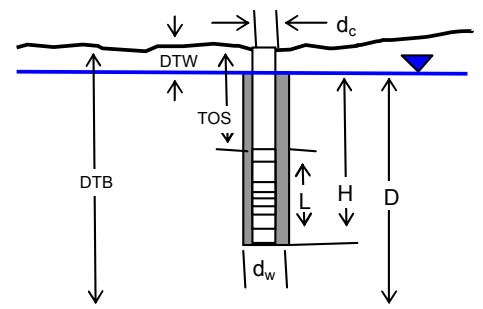

Base of Aquifer

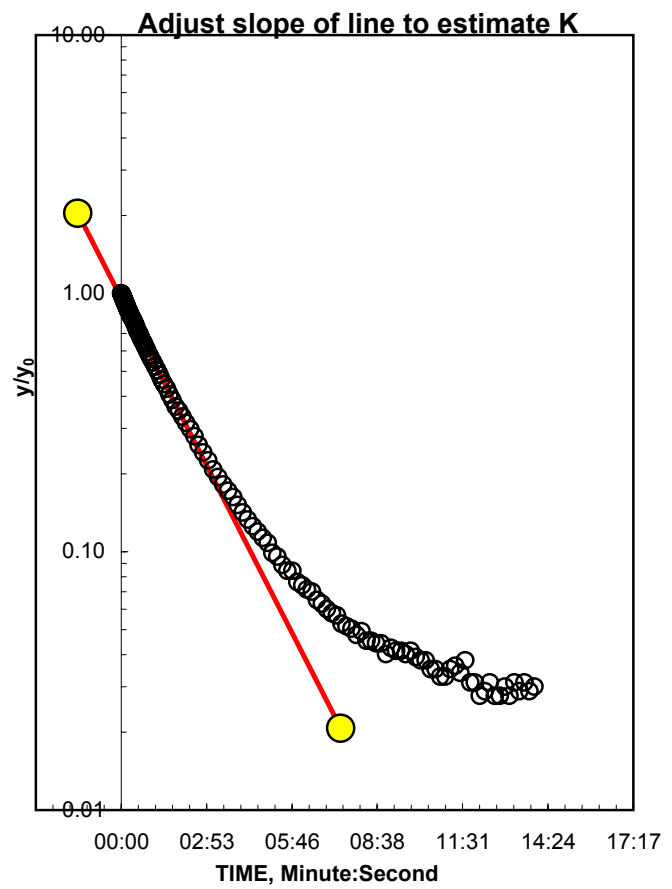

BCW-5A Slug in test \#1. DGS/BAH
Reduced Data

$$
\text { Time, }
$$

Hr:Min:Sec

0:00:05.2

0:00:06.6

0:00:07.9

0:00:09.2

0:00:10.5

0:00:11.8

0:00:13.2

0:00:14.5

$0: 00: 15.9$

0:00:17.6

$0: 00: 19.4$

0:00:21.4

$0: 00: 23.8$

0:00:26.3

0:00:29.2

$0: 00: 32.5$

$0: 00: 36.2$

$0: 00: 40.3$

0:00:44.9

0:00:50.0

$0: 00: 55.9$

0:01:02.4

0:01:09.7

0:01:17.9

0:01:27.1

$0: 01: 37.4$

0:01:49.0

0:02:02.0

0:02:16.6

0:02:33.0

0:02:51.4

0:03:11.4

0:03:31.4

0:03:51.4

0:04:11.4

0:04:31.4

0:04:51.4

0:05:11.4

0:05:31.4

0:05:51.4

0:06:11.4

0:06:31.4

0:06:51.4

0:07:11.4

0:07:31.4
Water

Level

2.69

2.71

2.74

2.76

2.79

2.81

2.83

2.86

2.88

2.91

2.94

2.97

3.00

3.03

3.07

3.12

3.17

3.21

3.27

3.32

3.38

3.44

3.51

3.57

3.64

3.71

3.78

3.84

3.90

3.97

4.03

4.09

4.14

4.17

4.21

4.24

4.26

4.29

4.30

4.31

4.33

4.34

4.35

4.36 4.37 
Appendix 1D. Slug-test results for wells at the Ballards Crossroads aquifer-test site in the Little Contentnea Creek basin, Pitt County, North Carolina, 2002-03. _ Continued

WELL ID: Ballard's Crossroads well BCW-5A slug out1

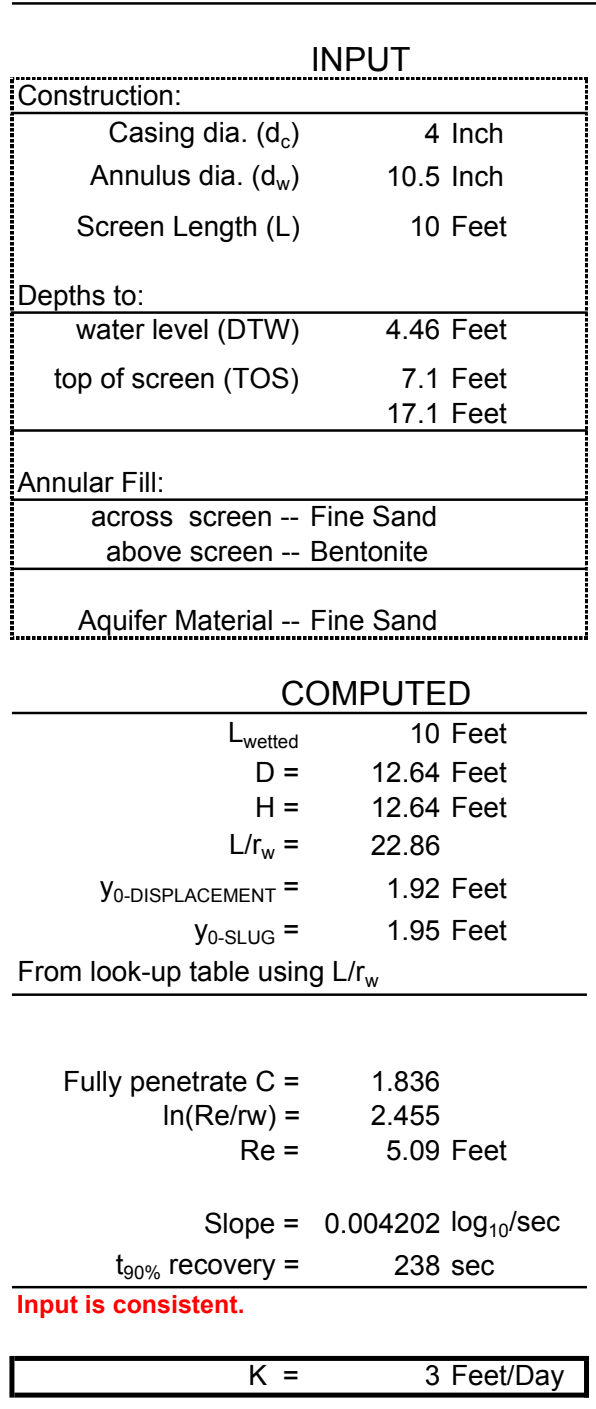

REMARKS:

Bouwer and Rice (1976) analysis of slug test

Local ID: BCW-5A

Date: $11 / 4 / 2003$

Time: 15:01:00 PM

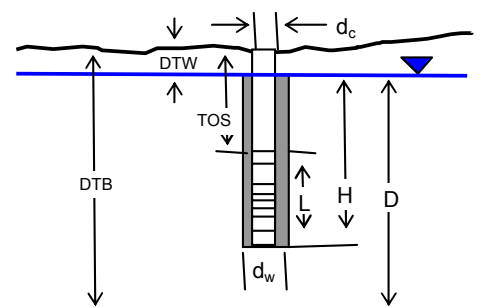

Base of Aquifer

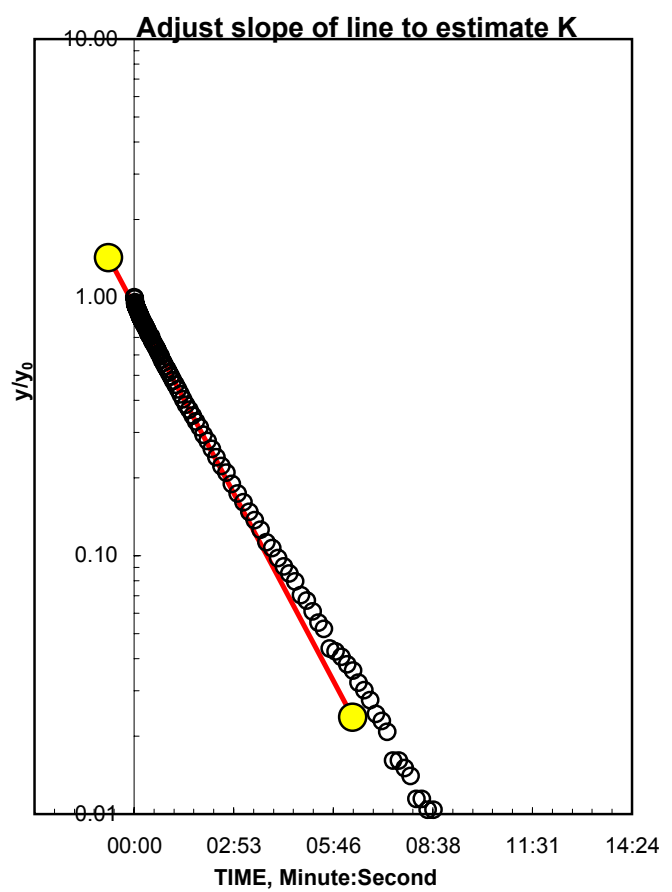

BCW-5A Slug out test \#1. DGS/BAH
Reduced Data

$$
\text { Time, }
$$

Water

Entry Hr:Min:Sec Level

$1 \quad 0: 00: 01.9 \quad 6.38$

$2 \quad 0: 00: 03.3 \quad 6.30$

$3 \quad 0: 00: 04.6 \quad 6.26$

$4 \quad 0: 00: 05.9 \quad 6.22$

$5 \quad 0: 00: 07.2 \quad 6.19$

$6 \quad 0: 00: 08.5 \quad 6.16$

$7 \quad 0: 00: 09.9 \quad 6.13$

$8 \quad 0: 00: 11.2 \quad 6.11$

$9 \quad 0: 00: 12.5 \quad 6.08$

$10 \quad 0: 00: 13.8 \quad 6.06$

$11 \quad 0: 00: 15.2 \quad 6.03$

$12 \quad 0: 00: 16.7 \quad 6.01$

$13 \quad 0: 00: 18.5 \quad 5.98$

$14 \quad 0: 00: 20.4 \quad 5.95$

$15 \quad 0: 00: 22.6 \quad 5.92$

$16 \quad 0: 00: 25.0 \quad 5.88$

$17 \quad 0: 00: 27.8 \quad 5.84$

$18 \quad 0: 00: 30.8 \quad 5.82$

$19 \quad 0: 00: 34.3 \quad 5.76$

$20 \quad 0: 00: 38.2 \quad 5.70$

$21 \quad 0: 00: 42.5 \quad 5.66$

$22 \quad 0: 00: 47.4 \quad 5.60$

$23 \quad 0: 00: 52.9 \quad 5.53$

$24 \quad 0: 00: 59.0 \quad 5.47$

$25 \quad 0: 01: 05.9 \quad 5.41$

$26 \quad 0: 01: 13.7 \quad 5.34$

$27 \quad 0: 01: 22.4 \quad 5.27$

$28 \quad 0: 01: 32.1 \quad 5.20$

$29 \quad 0: 01: 43.1 \quad 5.13$

$30 \quad 0: 01: 55.3 \quad 5.06$

$31 \quad 0: 02: 09.1 \quad 4.99$

$32 \quad 0: 02: 24.6 \quad 4.92$

$33 \quad 0: 02: 41.9 \quad 4.86$

$34 \quad 0: 03: 01.4 \quad 4.80$

$35 \quad 0: 03: 21.4 \quad 4.74$

$36 \quad 0: 03: 41.4 \quad 4.70$

$37 \quad 0: 04: 01.4 \quad 4.67$

$38 \quad 0: 04: 21.4 \quad 4.64$

$39 \quad 0: 04: 41.4 \quad 4.61$

$40 \quad 0: 05: 01.4 \quad 4.59$

$41 \quad 0: 05: 21.4 \quad 4.57$

$42 \quad 0: 05: 41.4 \quad 4.54$

$43 \quad 0: 06: 01.4 \quad 4.54$

$44 \quad 0: 06: 21.4 \quad 4.53$

$45 \quad 0: 06: 41.4 \quad 4.52$ 
Appendix 1D. Slug-test results for wells at the Ballards Crossroads aquifer-test site in the Little Contentnea Creek basin, Pitt County, North Carolina, 2002-03. - Continued

WELL ID: Ballard's Crossroads well BCW-5B slug in1

\begin{tabular}{|c|c|}
\hline & NPUT \\
\hline \multicolumn{2}{|l|}{ Construction: } \\
\hline Casing dia. $\left(\mathrm{d}_{\mathrm{c}}\right)$ & 4 Inch \\
\hline Annulus dia. $\left(\mathrm{d}_{\mathrm{w}}\right)$ & 10.5 Inch \\
\hline Screen Length $(L)$ & 10 Feet \\
\hline \multicolumn{2}{|l|}{ Depths to: } \\
\hline water level (DTW) & 4.46 Feet \\
\hline top of screen (TOS) & $\begin{array}{r}\text { 7.1 Feet } \\
\text { 17.1 Feet }\end{array}$ \\
\hline \multicolumn{2}{|c|}{ Annular Fill: } \\
\hline \multicolumn{2}{|c|}{$\begin{array}{l}\text { across screen -- Coarse Sand } \\
\text { above screen -- Bentonite }\end{array}$} \\
\hline \multicolumn{2}{|c|}{ Aquifer Material -- Fine Sand } \\
\hline \multicolumn{2}{|c|}{ COMPUTED } \\
\hline $\mathrm{L}_{\text {wetted }}$ & 10 Feet \\
\hline$D=$ & 13.25 Feet \\
\hline $\mathrm{H}=$ & 13.25 Feet \\
\hline $\mathrm{L} / \mathrm{r}_{\mathrm{w}}=$ & 22.86 \\
\hline $\mathrm{y}_{0 \text {-DISPLACEMENT }}=$ & 1.88 Feet \\
\hline $\mathrm{y}_{0-\mathrm{SLUG}}=$ & 1.95 Feet \\
\hline \multicolumn{2}{|c|}{ From look-up table using $\mathrm{L} / \mathrm{r}_{\mathrm{w}}$} \\
\hline Fully penetrate $\mathrm{C}=$ & 1.836 \\
\hline $\ln (\mathrm{Re} / \mathrm{rw})=$ & 2.482 \\
\hline $\operatorname{Re}=$ & 5.24 Feet \\
\hline Slope $=$ & $0.010175 \log _{10} / \mathrm{sec}$ \\
\hline $\mathrm{t}_{90 \%}$ recovery $=$ & $98 \mathrm{sec}$ \\
\hline \multicolumn{2}{|l|}{ Input is consistent. } \\
\hline $\mathrm{K}=$ & 7 Feet/Day \\
\hline
\end{tabular}

REMARKS:

Bouwer and Rice (1976) analysis of slug test Local ID: BCW-5B

Date: $11 / 4 / 2003$

Time: 16:26:00 PM
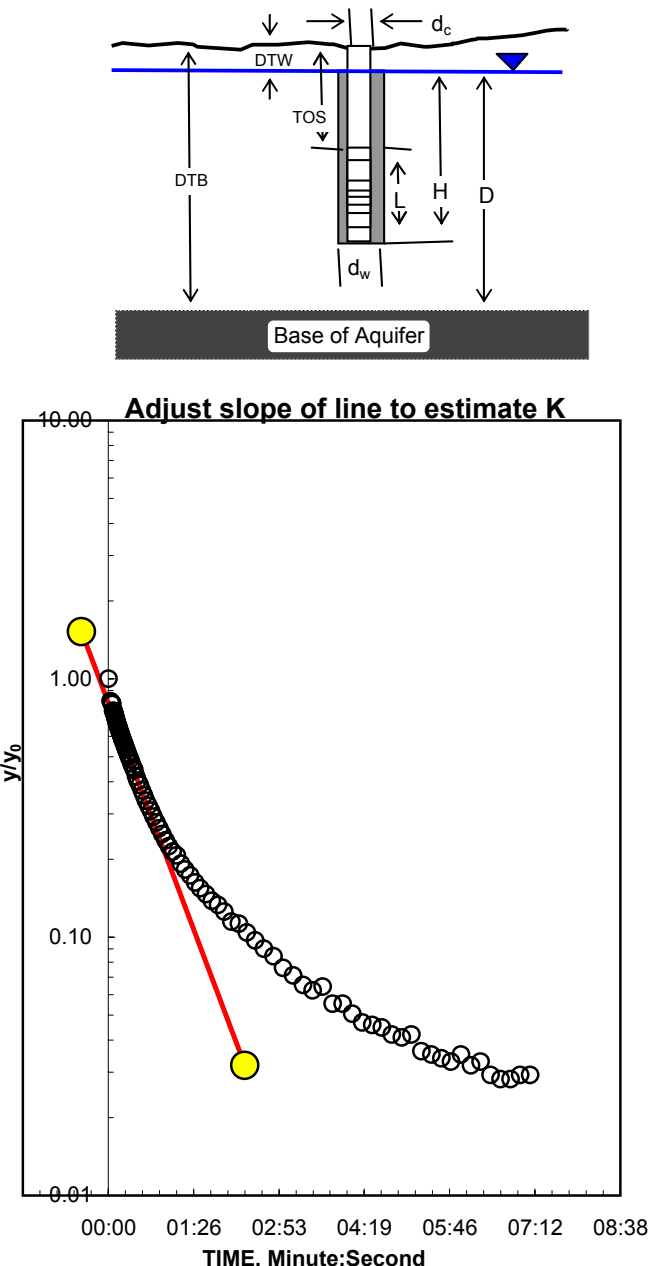

BCW-5B Slug in test \#1. DGS/BAH
Reduced Data Time, Water Entry Hr:Min:Sec Level $1 \quad 0: 00: 04.6 \quad 2.58$

$2 \quad 0: 00: 06.6 \quad 2.92$

$3 \quad 0: 00: 07.9 \quad 2.94$

$4 \quad 0: 00: 08.6 \quad 2.96$

$5 \quad 0: 00: 09.3 \quad 3.04$

$6 \quad 0: 00: 09.9 \quad 3.05$

$7 \quad 0: 00: 10.6 \quad 3.08$

$8 \quad 0: 00: 11.2 \quad 3.11$

$9 \quad 0: 00: 11.9 \quad 3.14$

$10 \quad 0: 00: 12.6 \quad 3.16$

$11 \quad 0: 00: 13.2 \quad 3.19$

$12 \quad 0: 00: 13.9 \quad 3.21$

$13 \quad 0: 00: 14.5 \quad 3.24$

$14 \quad 0: 00: 15.2 \quad 3.26$

$15 \quad 0: 00: 16.0 \quad 3.28$

$16 \quad 0: 00: 16.8 \quad 3.31$

$17 \quad 0: 00: 17.6 \quad 3.33$

$18 \quad 0: 00: 18.5 \quad 3.36$

$19 \quad 0: 00: 19.5 \quad 3.38$

$20 \quad 0: 00: 20.5 \quad 3.41$

$21 \quad 0: 00: 21.5 \quad 3.44$

$22 \quad 0: 00: 22.6 \quad 3.46$

$23 \quad 0: 00: 23.8 \quad 3.49$

$24 \quad 0: 00: 25.1 \quad 3.52$

$25 \quad 0: 00: 26.4 \quad 3.54$

$26 \quad 0: 00: 27.8 \quad 3.57$

$27 \quad 0: 00: 29.3 \quad 3.61$

$28 \quad 0: 00: 30.9 \quad 3.63$

$29 \quad 0: 00: 32.6 \quad 3.67$

$30 \quad 0: 00: 34.4 \quad 3.70$

$31 \quad 0: 00: 36.2 \quad 3.73$

$32 \quad 0: 00: 38.2 \quad 3.76$

$33 \quad 0: 00: 40.3 \quad 3.79$

$34 \quad 0: 00: 42.6 \quad 3.83$

$35 \quad 0: 00: 44.9 \quad 3.85$

$36 \quad 0: 00: 47.5 \quad 3.88$

$37 \quad 0: 00: 50.1 \quad 3.91$

$38 \quad 0: 00: 52.9 \quad 3.94$

$39 \quad 0: 00: 55.9 \quad 3.96$

$40 \quad 0: 00: 59.1 \quad 3.99$

$41 \quad 0: 01: 02.4 \quad 4.02$

$42 \quad 0: 01: 06.0 \quad 4.04$

$43 \quad 0: 01: 09.7 \quad 4.06$

$44 \quad 0: 01: 13.7 \quad 4.07$

$45 \quad 0: 01: 17.9 \quad 4.10$ 
Appendix 1D. Slug-test results for wells at the Ballards Crossroads aquifer-test site in the Little Contentnea Creek basin, Pitt County, North Carolina, 2002-03. _ Continued

WELL ID: Ballard's Crossroads well BCW-5B slug out1

\begin{tabular}{|c|c|}
\hline & INPUT \\
\hline \multicolumn{2}{|l|}{ Construction: } \\
\hline Casing dia. $\left(\mathrm{d}_{\mathrm{c}}\right)$ & 4 Inch \\
\hline Annulus dia. $\left(\mathrm{d}_{\mathrm{w}}\right)$ & 10.5 Inch \\
\hline Screen Length $(\mathrm{L})$ & 10 Feet \\
\hline \multicolumn{2}{|l|}{ Depths to: } \\
\hline water level (DTW) & 4.46 Feet \\
\hline top of screen (TOS) & $\begin{array}{r}7.1 \text { Feet } \\
17.1 \text { Feet }\end{array}$ \\
\hline \multicolumn{2}{|c|}{ Annular Fill: } \\
\hline \multicolumn{2}{|c|}{$\begin{array}{c}\text { across screen -- Coarse Sand } \\
\text { above screen -- Bentonite }\end{array}$} \\
\hline \multicolumn{2}{|c|}{ Aquifer Material -- Fine Sand } \\
\hline \multicolumn{2}{|c|}{ COMPUTED } \\
\hline $\mathrm{L}_{\text {wetted }}$ & 10 Feet \\
\hline$D=$ & 13.26 Feet \\
\hline $\mathrm{H}=$ & 13.26 Feet \\
\hline $\mathrm{L} / \mathrm{r}_{\mathrm{w}}=$ & 22.86 \\
\hline $\mathrm{y}_{0 \text {-DISPLACEMENT }}=$ & 1.99 Feet \\
\hline $\mathrm{y}_{0-S L U G}=$ & 1.95 Feet \\
\hline \multicolumn{2}{|c|}{ From look-up table using $\mathrm{L} / \mathrm{r}_{\mathrm{w}}$} \\
\hline Fully penetrate $\mathrm{C}=$ & 1.836 \\
\hline $\ln (\mathrm{Re} / \mathrm{rw})=$ & 2.483 \\
\hline $\operatorname{Re}=$ & 5.24 Feet \\
\hline Slope $=$ & $0.010563 \log _{10} / \mathrm{sec}$ \\
\hline$t_{90 \%}$ recovery $=$ & $95 \mathrm{sec}$ \\
\hline \multicolumn{2}{|l|}{ Input is consistent. } \\
\hline $\mathrm{K}=$ & 7 Feet/Day \\
\hline
\end{tabular}

REMARKS:

Bouwer and Rice (1976) analysis of slug test Local ID: BCW-5B

Date: $11 / 4 / 2003$

Time: 16:13:00 PM
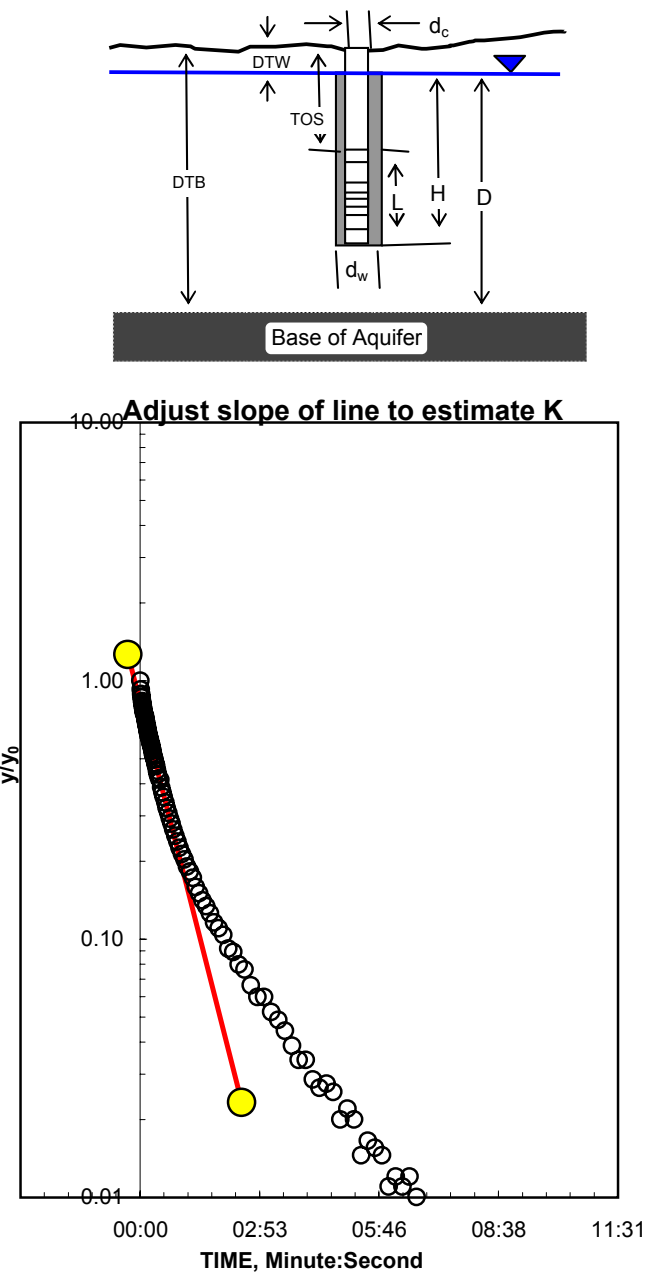

BCW-5B Slug out test \#1. DGS/BAH
Reduced Data

Time, Water

Hr:Min:Sec Level

$1 \quad 0: 00: 02.0 \quad 6.45$

$2 \quad 0: 00: 03.3 \quad 6.23$

$3 \quad 0: 00: 04.6 \quad 6.12$

$4 \quad 0: 00: 06.0 \quad 6.04$

$5 \quad 0: 00: 07.3 \quad 5.98$

$6 \quad 0: 00: 08.6 \quad 5.92$

$7 \quad 0: 00: 09.9 \quad 5.86$

$8 \quad 0: 00: 11.2 \quad 5.80$

$9 \quad 0: 00: 12.6 \quad 5.75$

$10 \quad 0: 00: 13.9 \quad 5.70$

$11 \quad 0: 00: 15.2 \quad 5.65$

$12 \quad 0: 00: 16.8 \quad 5.61$

$13 \quad 0: 00: 18.5 \quad 5.56$

$14 \quad 0: 00: 20.4 \quad 5.50$

$15 \quad 0: 00: 22.6 \quad 5.45$

$16 \quad 0: 00: 25.1 \quad 5.39$

$17 \quad 0: 00: 27.8 \quad 5.32$

$18 \quad 0: 00: 30.9 \quad 5.28$

$19 \quad 0: 00: 34.3 \quad 5.20$

$20 \quad 0: 00: 38.2 \quad 5.13$

$21 \quad 0: 00: 42.6 \quad 5.08$

$22 \quad 0: 00: 47.4 \quad 5.02$

$23 \quad 0: 00: 52.9 \quad 4.96$

$24 \quad 0: 00: 59.1 \quad 4.91$

$25 \quad 0: 01: 06.0 \quad 4.87$

$26 \quad 0: 01: 13.7 \quad 4.82$

$27 \quad 0: 01: 22.4 \quad 4.78$

$28 \quad 0: 01: 32.2 \quad 4.74$

$29 \quad 0: 01: 43.1 \quad 4.71$

$30 \quad 0: 01: 55.4 \quad 4.68$

$31 \quad 0: 02: 09.2 \quad 4.64$

$32 \quad 0: 02: 24.6 \quad 4.62$

$33 \quad 0: 02: 42.0 \quad 4.59$

$34 \quad 0: 03: 01.4 \quad 4.58$

$35 \quad 0: 03: 21.4 \quad 4.56$

$36 \quad 0: 03: 41.4 \quad 4.54$

$37 \quad 0: 04: 01.4 \quad 4.53$

$38 \quad 0: 04: 21.4 \quad 4.51$

$39 \quad 0: 04: 41.4 \quad 4.51$

$40 \quad 0: 05: 01.4 \quad 4.50$

$41 \quad 0: 05: 21.4 \quad 4.49$

$42 \quad 0: 05: 41.4 \quad 4.49$

$43 \quad 0: 06: 01.4 \quad 4.48$

$44 \quad 0: 06: 21.4 \quad 4.48$

$45 \quad 0: 06: 41.4 \quad 4.48$ 
Appendix 1D. Slug-test results for wells at the Ballards Crossroads aquifer-test site in the Little Contentnea Creek basin, Pitt County, North Carolina, 2002-03. - Continued

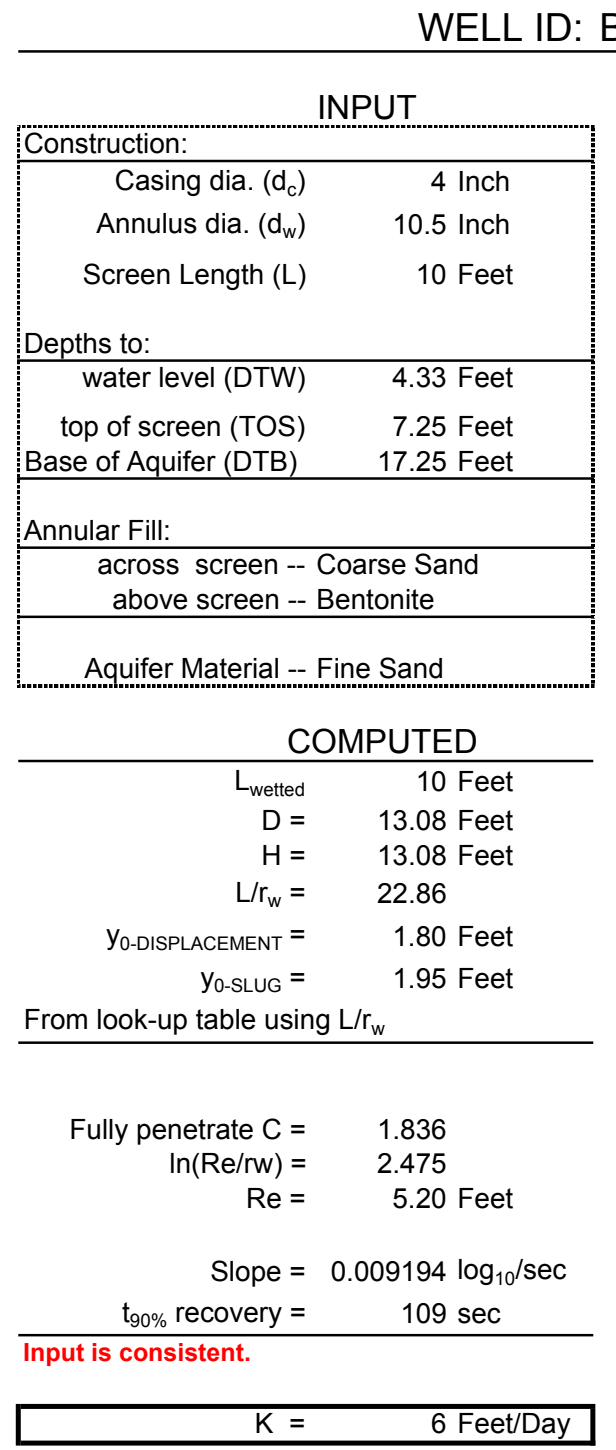

REMARKS:

BCW-5C Slug in test \#1. DGS/BAH
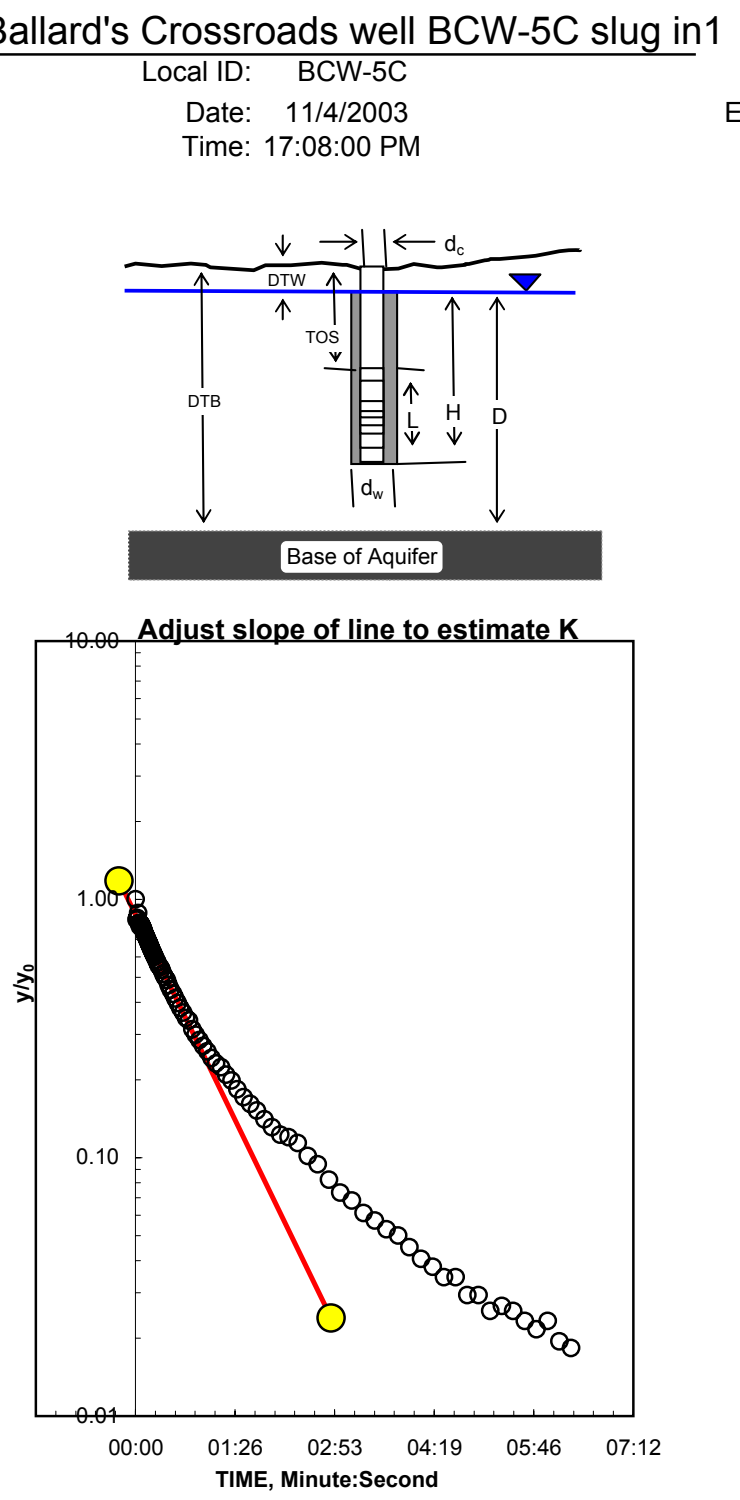

Bouwer and Rice (1976) analysis of slug test
Reduced Data

Time, Water

Entry Hr:Min:Sec Level

$1 \quad 0: 00: 04.0 \quad 2.52$

$2 \quad 0: 00: 04.7 \quad 2.82$

$3 \quad 0: 00: 05.3 \quad 2.79$

$4 \quad 0: 00: 06.0 \quad 2.73$

$5 \quad 0: 00: 06.7 \quad 2.86$

$6 \quad 0: 00: 07.3 \quad 2.90$

$\begin{array}{lll}7 & 0: 00: 08.0 & 2.87\end{array}$

$8 \quad 0: 00: 08.6 \quad 2.88$

$9 \quad 0: 00: 09.3 \quad 2.90$

$10 \quad 0: 00: 10.0 \quad 2.93$

$11 \quad 0: 00: 10.6 \quad 2.95$

$12 \quad 0: 00: 11.3 \quad 2.98$

$13 \quad 0: 00: 11.9 \quad 3.00$

$14 \quad 0: 00: 12.6 \quad 3.02$

$15 \quad 0: 00: 13.3 \quad 3.04$

$16 \quad 0: 00: 13.9 \quad 3.06$

$17 \quad 0: 00: 14.6 \quad 3.09$

$18 \quad 0: 00: 15.3 \quad 3.11$

$19 \quad 0: 00: 16.0 \quad 3.13$

$20 \quad 0: 00: 16.8 \quad 3.15$

$21 \quad 0: 00: 17.7 \quad 3.17$

$22 \quad 0: 00: 18.5 \quad 3.19$

$23 \quad 0: 00: 19.5 \quad 3.22$

$24 \quad 0: 00: 20.5 \quad 3.24$

$25 \quad 0: 00: 21.5 \quad 3.27$

$26 \quad 0: 00: 22.7 \quad 3.29$

$27 \quad 0: 00: 23.9 \quad 3.32$

$28 \quad 0: 00: 25.1 \quad 3.34$

$29 \quad 0: 00: 26.4 \quad 3.36$

$30 \quad 0: 00: 27.9 \quad 3.39$

$31 \quad 0: 00: 29.3 \quad 3.42$

$32 \quad 0: 00: 30.9 \quad 3.44$

$33 \quad 0: 00: 32.6 \quad 3.48$

$34 \quad 0: 00: 34.4 \quad 3.52$

$35 \quad 0: 00: 36.3 \quad 3.55$

$36 \quad 0: 00: 38.3 \quad 3.58$

$37 \quad 0: 00: 40.4 \quad 3.61$

$38 \quad 0: 00: 42.6 \quad 3.64$

$39 \quad 0: 00: 45.0 \quad 3.66$

$40 \quad 0: 00: 47.5 \quad 3.70$

$41 \quad 0: 00: 50.1 \quad 3.71$

$42 \quad 0: 00: 53.0 \quad 3.76$

$43 \quad 0: 00: 56.0 \quad 3.78$

$44 \quad 0: 00: 59.1 \quad 3.81$

$45 \quad 0: 01: 02.5 \quad 3.83$ 
Appendix 1D. Slug-test results for wells at the Ballards Crossroads aquifer-test site in the Little Contentnea Creek basin, Pitt County, North Carolina, 2002-03. _ Continued

WELL ID: Ballard's Crossroads well BCW-5C slug out1

\begin{tabular}{|c|c|}
\hline \multicolumn{2}{|c|}{ INPUT } \\
\hline \\
\hline Casing dia. $\left(d_{c}\right)$ & 4 Inch \\
\hline Annulus dia. $\left(\mathrm{d}_{\mathrm{w}}\right)$ & 10.5 Inch \\
\hline Screen Length (L) & 10 Feet \\
\hline \multicolumn{2}{|l|}{ Depths to: } \\
\hline water level (DTW) & 4.33 Feet \\
\hline top of screen (TOS) & $\begin{array}{r}7.25 \text { Feet } \\
17.25 \text { Feet }\end{array}$ \\
\hline \multicolumn{2}{|c|}{ Annular Fill: } \\
\hline \multicolumn{2}{|c|}{$\begin{array}{c}\text { across screen -- Coarse Sand } \\
\text { above screen -- Bentonite }\end{array}$} \\
\hline \multicolumn{2}{|c|}{ Aquifer Material -- Fine Sand } \\
\hline \multicolumn{2}{|c|}{ COMPUTED } \\
\hline $\mathrm{L}_{\text {wetted }}$ & 10 Feet \\
\hline $\begin{array}{l}D= \\
H=\end{array}$ & $\begin{array}{l}\text { 13.1 Feet } \\
\text { 13.1 Feet }\end{array}$ \\
\hline $\mathrm{L} / \mathrm{r}_{\mathrm{w}}=$ & 22.86 \\
\hline $\mathrm{y}_{0 \text {-DISPLACEMENT }}=$ & 1.74 Feet \\
\hline $\mathrm{y}_{0-S L U G}=$ & 1.95 Feet \\
\hline \multicolumn{2}{|c|}{ From look-up table using $\mathrm{L} / \mathrm{r}_{\mathrm{w}}$} \\
\hline Fully penetrate $\mathrm{C}=$ & 1.836 \\
\hline $\ln (\mathrm{Re} / \mathrm{rw})=$ & 2.476 \\
\hline $\operatorname{Re}=$ & 5.20 Feet \\
\hline Slope $=$ & $0.010149 \log _{10} / \mathrm{sec}$ \\
\hline$t_{90 \%}$ recovery $=$ & $99 \mathrm{sec}$ \\
\hline \multicolumn{2}{|l|}{ Input is consistent. } \\
\hline $\mathrm{K}=$ & 7 Feet/Day \\
\hline
\end{tabular}

REMARKS:

Bouwer and Rice (1976) analysis of slug test

Local ID: BCW-5C

Date: $\quad 11 / 4 / 2003$

Time: 17:16:00 PM

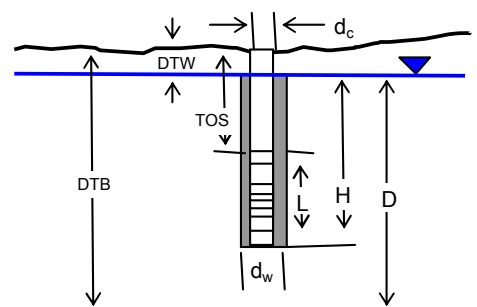

Base of Aquifer

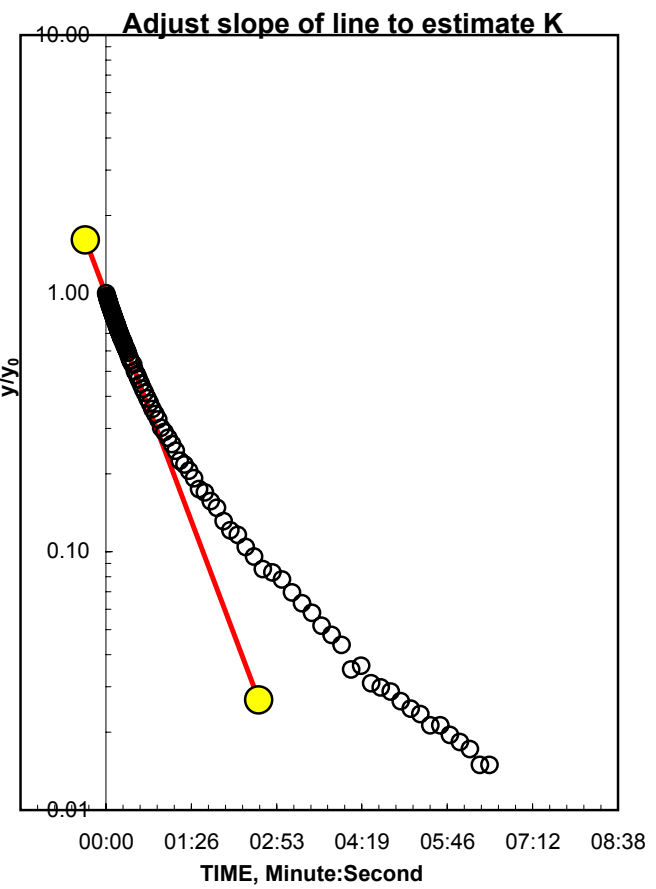

BCW-5C Slug out test \#1. DGS/BAH
Reduced Data

$$
\text { Time, }
$$

Water

Entry Hr:Min:Sec Level

$1 \quad 0: 00: 03.4 \quad 6.07$

$2 \quad 0: 00: 04.7 \quad 6.00$

$3 \quad 0: 00: 06.0 \quad 5.94$

$4 \quad 0: 00: 07.3 \quad 5.88$

$5 \quad 0: 00: 08.6 \quad 5.83$

$6 \quad 0: 00: 10.0 \quad 5.78$

$7 \quad 0: 00: 11.3 \quad 5.73$

$8 \quad 0: 00: 12.6 \quad 5.69$

$9 \quad 0: 00: 13.9 \quad 5.64$

$10 \quad 0: 00: 15.3 \quad 5.60$

$11 \quad 0: 00: 16.8 \quad 5.56$

$12 \quad 0: 00: 18.6 \quad 5.51$

$13 \quad 0: 00: 20.5 \quad 5.46$

$14 \quad 0: 00: 22.7 \quad 5.41$

$15 \quad 0: 00: 25.1 \quad 5.36$

$16 \quad 0: 00: 27.9 \quad 5.29$

$17 \quad 0: 00: 30.9 \quad 5.25$

$18 \quad 0: 00: 34.4 \quad 5.17$

$19 \quad 0: 00: 38.3 \quad 5.11$

$20 \quad 0: 00: 42.6 \quad 5.05$

$21 \quad 0: 00: 47.5 \quad 4.99$

$22 \quad 0: 00: 53.0 \quad 4.93$

$23 \quad 0: 00: 59.1 \quad 4.86$

$24 \quad 0: 01: 06.0 \quad 4.81$

$25 \quad 0: 01: 13.8 \quad 4.76$

$26 \quad 0: 01: 22.5 \quad 4.71$

$27 \quad 0: 01: 32.2 \quad 4.67$

$28 \quad 0: 01: 43.2 \quad 4.63$

$29 \quad 0: 01: 55.4 \quad 4.59$

$30 \quad 0: 02: 09.2 \quad 4.54$

$31 \quad 0: 02: 24.7 \quad 4.51$

$32 \quad 0: 02: 42.0 \quad 4.48$

$33 \quad 0: 03: 01.5 \quad 4.47$

$34 \quad 0: 03: 21.5 \quad 4.44$

$35 \quad 0: 03: 41.5 \quad 4.42$

$36 \quad 0: 04: 01.5 \quad 4.41$

$37 \quad 0: 04: 21.5 \quad 4.39$

$38 \quad 0: 04: 41.5 \quad 4.38$

$39 \quad 0: 05: 01.5 \quad 4.38$

$40 \quad 0: 05: 21.5 \quad 4.37$

$41 \quad 0: 05: 41.5 \quad 4.37$

$42 \quad 0: 06: 01.5 \quad 4.36$

$43 \quad 0: 06: 21.5 \quad 4.36$

$44 \quad 0: 06: 41.5 \quad 4.34$

$45 \quad 0: 07: 01.5 \quad 4.35$ 
Appendix 1E. Slug-test results for wells at the Farmville aquifer-test site in the Little Contentnea Creek basin, Pitt County, North Carolina, 2002-03.

WELL ID: BFW-7 SLUG OUT 3

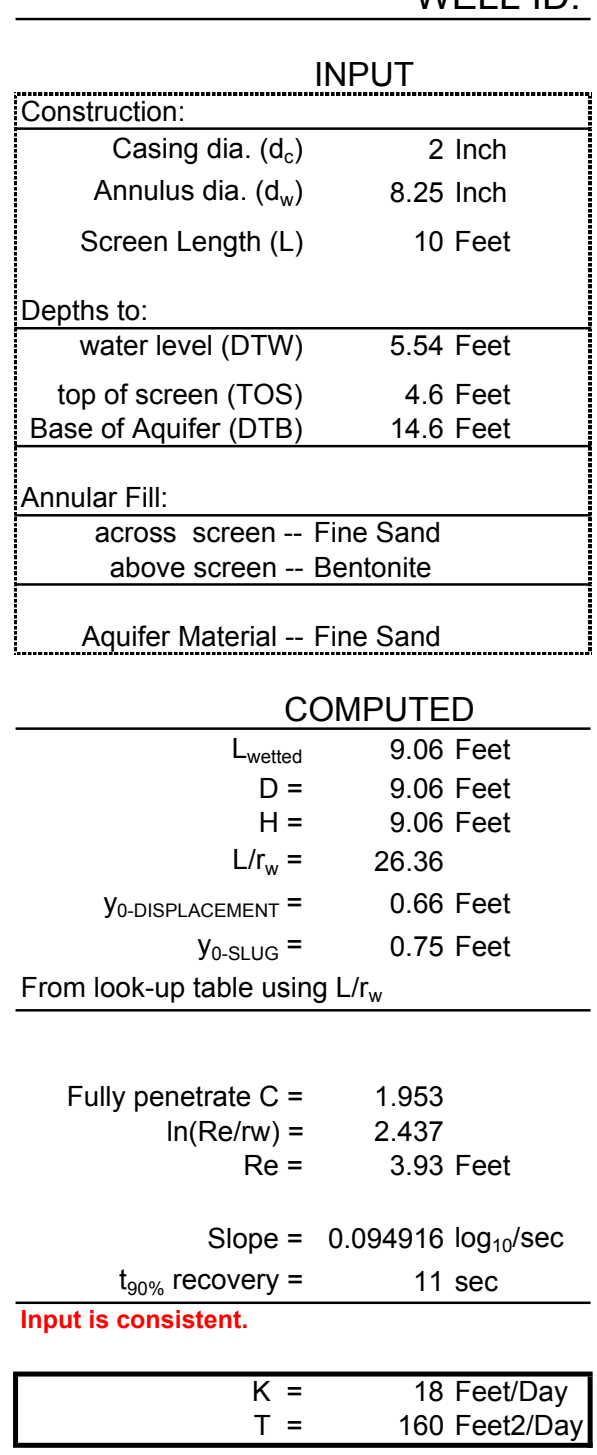

REMARKS:

Farmville site, well BFW-7, slug out 3 assumed annulus dia 8.25 assumed slug length 3 '
Local ID: BFW-7 SLUG OUT 3

Date: $5 / 20 / 2004$

Time: $\quad$ 0:00
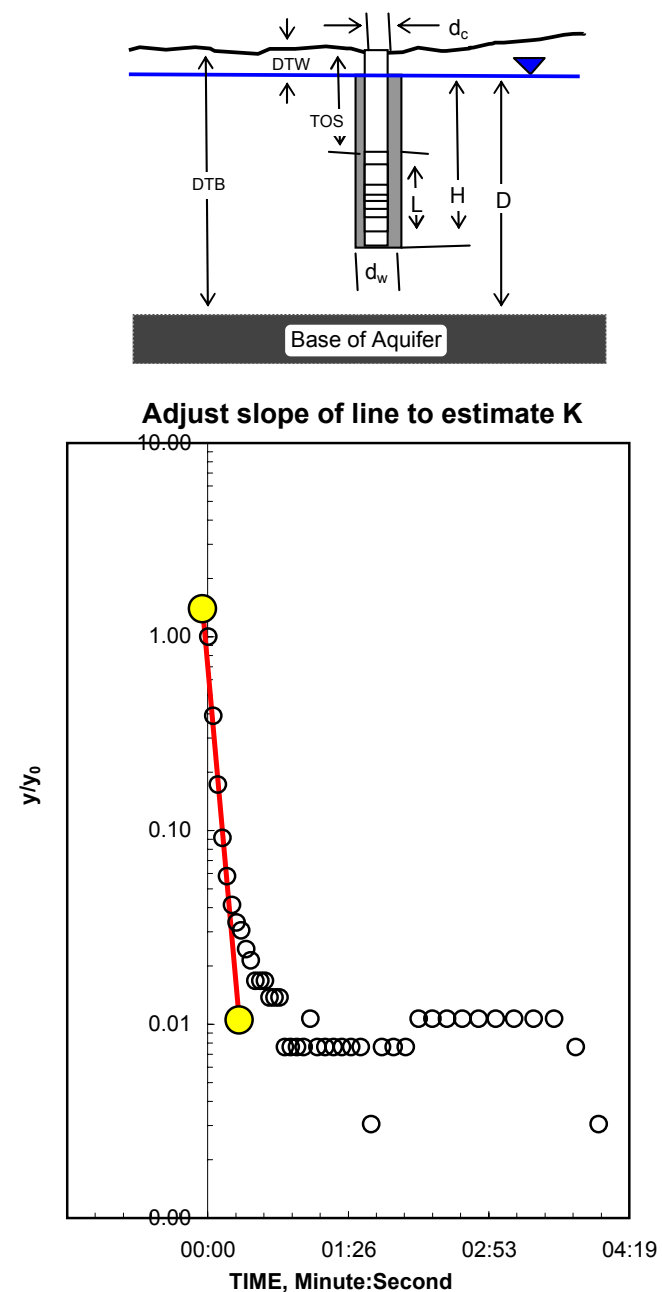

Bouwer and Rice (1976) analysis of slug test

$\begin{array}{ccc} & \text { Reduced Data } & \\ & \text { Time, } & \text { Water } \\ \text { Entry } & \text { Hr:Min:Sec } & \text { Level } \\ 1 & 0: 00: 00.0 & 6.29 \\ 2 & 0: 00: 02.9 & 5.89 \\ 3 & 0: 00: 05.8 & 5.74 \\ 4 & 0: 00: 08.7 & 5.69 \\ 5 & 0: 00: 11.6 & 5.67 \\ 6 & 0: 00: 14.5 & 5.66 \\ 7 & 0: 00: 17.4 & 5.65 \\ 8 & 0: 00: 20.3 & 5.65 \\ 9 & 0: 00: 23.2 & 5.65 \\ 10 & 0: 00: 26.1 & 5.64 \\ 11 & 0: 00: 29.0 & 5.64 \\ 12 & 0: 00: 31.9 & 5.64 \\ 13 & 0: 00: 34.8 & 5.64 \\ 14 & 0: 00: 37.7 & 5.64 \\ 15 & 0: 00: 40.7 & 5.64 \\ 16 & 0: 00: 43.9 & 5.64 \\ 17 & 0: 00: 47.2 & 5.64 \\ 18 & 0: 00: 50.8 & 5.64 \\ 19 & 0: 00: 54.5 & 5.64 \\ 20 & 0: 00: 58.5 & 5.64 \\ 21 & 0: 01: 02.7 & 5.64 \\ 22 & 0: 01: 07.2 & 5.64 \\ 23 & 0: 01: 11.9 & 5.64 \\ 24 & 0: 01: 16.9 & 5.64 \\ 25 & 0: 01: 22.3 & 5.64 \\ 26 & 0: 01: 27.9 & 5.64 \\ 27 & 0: 01: 33.8 & 5.64 \\ 28 & 0: 01: 40.2 & 5.63 \\ 29 & 0: 01: 46.9 & 5.64 \\ 30 & 0: 01: 53.9 & 5.64 \\ 31 & 0: 02: 01.5 & 5.64 \\ 32 & 0: 02: 09.4 & 5.64 \\ 33 & 0: 02: 17.8 & 5.64 \\ 34 & 0: 02: 26.8 & 5.64 \\ 35 & 0: 02: 36.2 & 5.64 \\ 36 & 0: 02: 46.2 & 5.64 \\ 37 & 0: 02: 56.8 & 5.64 \\ 38 & 0: 03: 08.1 & 5.64 \\ 39 & 0: 03: 20.0 & 5.64 \\ 40 & 0: 03: 32.6 & 5.64 \\ 41 & 0: 03: 45.9 & 5.64 \\ & & \end{array}$


Appendix 1E. Slug-test results for wells at the Farmville aquifer-test site in the Little Contentnea Creek basin, Pitt County, North Carolina, 2002-03. - Continued

WELL ID: BFW-8 SLUG OUT 3

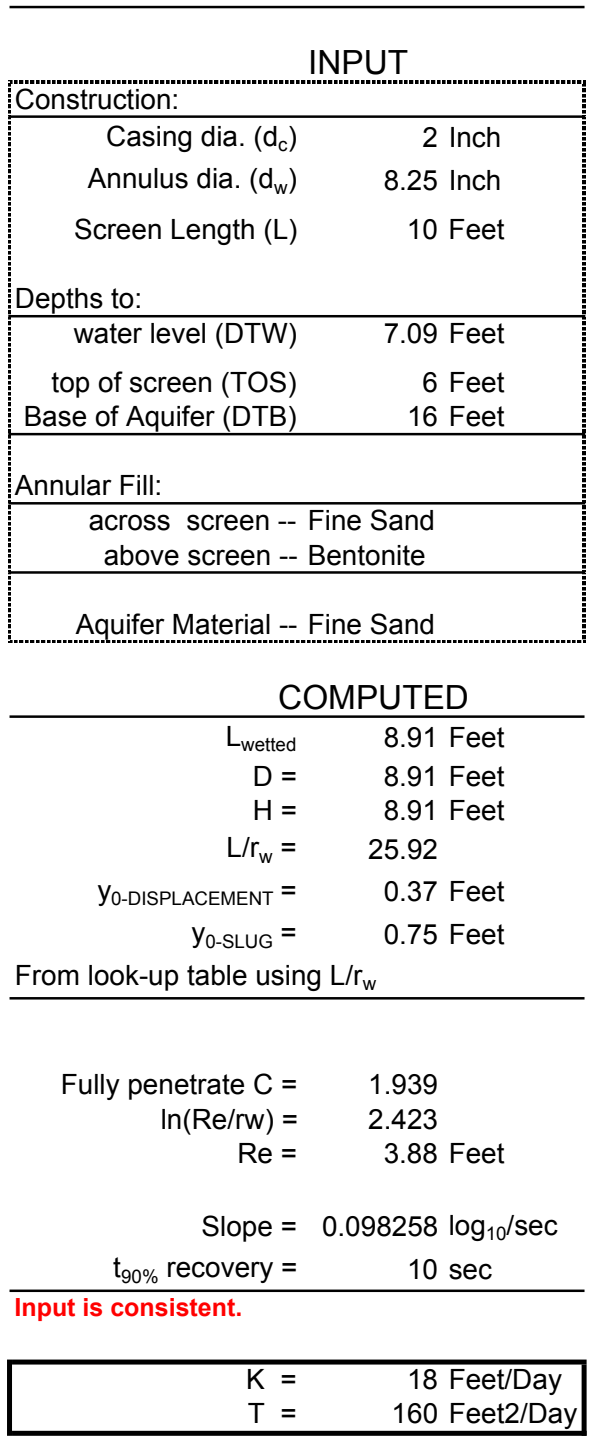

Local ID: BFW-8 SLUG OUT 3

Date: $5 / 20 / 2004$

Time: $\quad 0: 00$
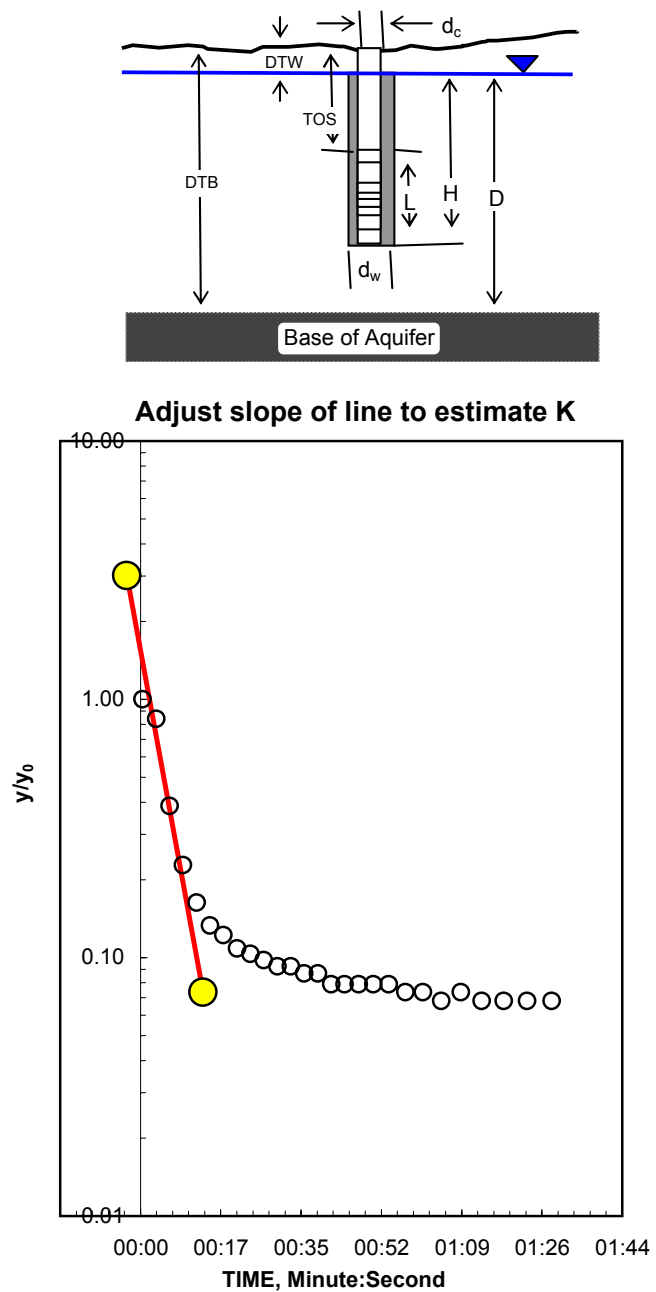

Reduced Data Time, Water Hr:Min:Sec Level $0: 00: 00.0 \quad 7.51$ $0: 00: 02.9 \quad 7.45$ 0:00:05.8 $\quad 7.28$ $0: 00: 08.7 \quad 7.22$ $0: 00: 11.6 \quad 7.20$ 0:00:14.5 $\quad 7.19$ $0: 00: 17.4 \quad 7.19$

$0: 00: 20.3 \quad 7.18$

$0: 00: 23.2 \quad 7.18$

$0: 00: 26.1 \quad 7.18$

$0: 00: 29.0 \quad 7.17$

$0: 00: 31.9 \quad 7.17$

$0: 00: 34.8 \quad 7.17$

$0: 00: 37.7 \quad 7.17$

0:00:40.6 $\quad 7.17$

$0: 00: 43.5 \quad 7.17$

$0: 00: 46.5 \quad 7.17$

$0: 00: 49.7 \quad 7.17$

$0: 00: 53.0 \quad 7.17$

$0: 00: 56.6 \quad 7.17$

$0: 01: 00.3 \quad 7.17$

$0: 01: 04.3 \quad 7.17$

0:01:08.5 $\quad 7.17$

0:01:13.0 $\quad 7.17$

$0: 01: 17.7 \quad 7.17$

0:01:22.7 $\quad 7.17$

REMARKS:

Bouwer and Rice (1976) analysis of slug test

Farmville site, well BFW-8, slug out 3

assumed annulus dia 8.25

assumed slug length 
Appendix 1E. Slug-test results for wells at the Farmville aquifer-test site in the Little Contentnea Creek basin, Pitt County, North Carolina, 2002-03. - Continued

WELL ID: BFW-9 SLUG OUT 3

\begin{tabular}{|c|c|}
\hline \multicolumn{2}{|c|}{ INPUT } \\
\hline \multicolumn{2}{|l|}{ Construction: } \\
\hline Casing dia. $\left(\mathrm{d}_{\mathrm{c}}\right)$ & 2 Inch \\
\hline Annulus dia. $\left(\mathrm{d}_{\mathrm{w}}\right)$ & 8.25 Inch \\
\hline Screen Length (L) & 10 Feet \\
\hline \multicolumn{2}{|l|}{ Depths to: } \\
\hline water level (DTW) & 6.22 Feet \\
\hline top of screen (TOS) & 5.4 Feet \\
\hline Base of Aquifer (DTB) & 15.4 Feet \\
\hline \multicolumn{2}{|c|}{ Annular Fill: } \\
\hline \multicolumn{2}{|c|}{$\begin{array}{c}\text { across screen -- Fine Sand } \\
\text { above screen -- Bentonite }\end{array}$} \\
\hline \multicolumn{2}{|c|}{ Aquifer Material -- Fine Sand } \\
\hline \multicolumn{2}{|c|}{ COMPUTED } \\
\hline$L_{\text {wetted }}$ & 9.18 Feet \\
\hline$D=$ & 9.18 Feet \\
\hline $\mathrm{H}=$ & 9.18 Feet \\
\hline $\mathrm{L} / \mathrm{r}_{\mathrm{w}}=$ & 26.71 \\
\hline $\mathrm{y}_{0 \text {-DISPLACEMENT }}=$ & 0.20 Feet \\
\hline $\mathrm{y}_{0-S L U G}=$ & 0.75 Feet \\
\hline \multicolumn{2}{|c|}{ From look-up table using $\mathrm{L} / \mathrm{r}_{\mathrm{w}}$} \\
\hline Fully penetrate $\mathrm{C}=$ & 1.964 \\
\hline $\ln (\operatorname{Re} / r w)=$ & 2.449 \\
\hline $\operatorname{Re}=$ & 3.98 Feet \\
\hline Slope $=$ & $0.097122 \log _{10} / \mathrm{sec}$ \\
\hline$t_{90 \%}$ recovery $=$ & $10 \mathrm{sec}$ \\
\hline \multicolumn{2}{|l|}{ Input is consistent. } \\
\hline $\begin{array}{l}\mathrm{K}= \\
\mathrm{T}=\end{array}$ & $\begin{array}{c}18 \text { Feet/Day } \\
170 \text { Feet2/Day }\end{array}$ \\
\hline
\end{tabular}

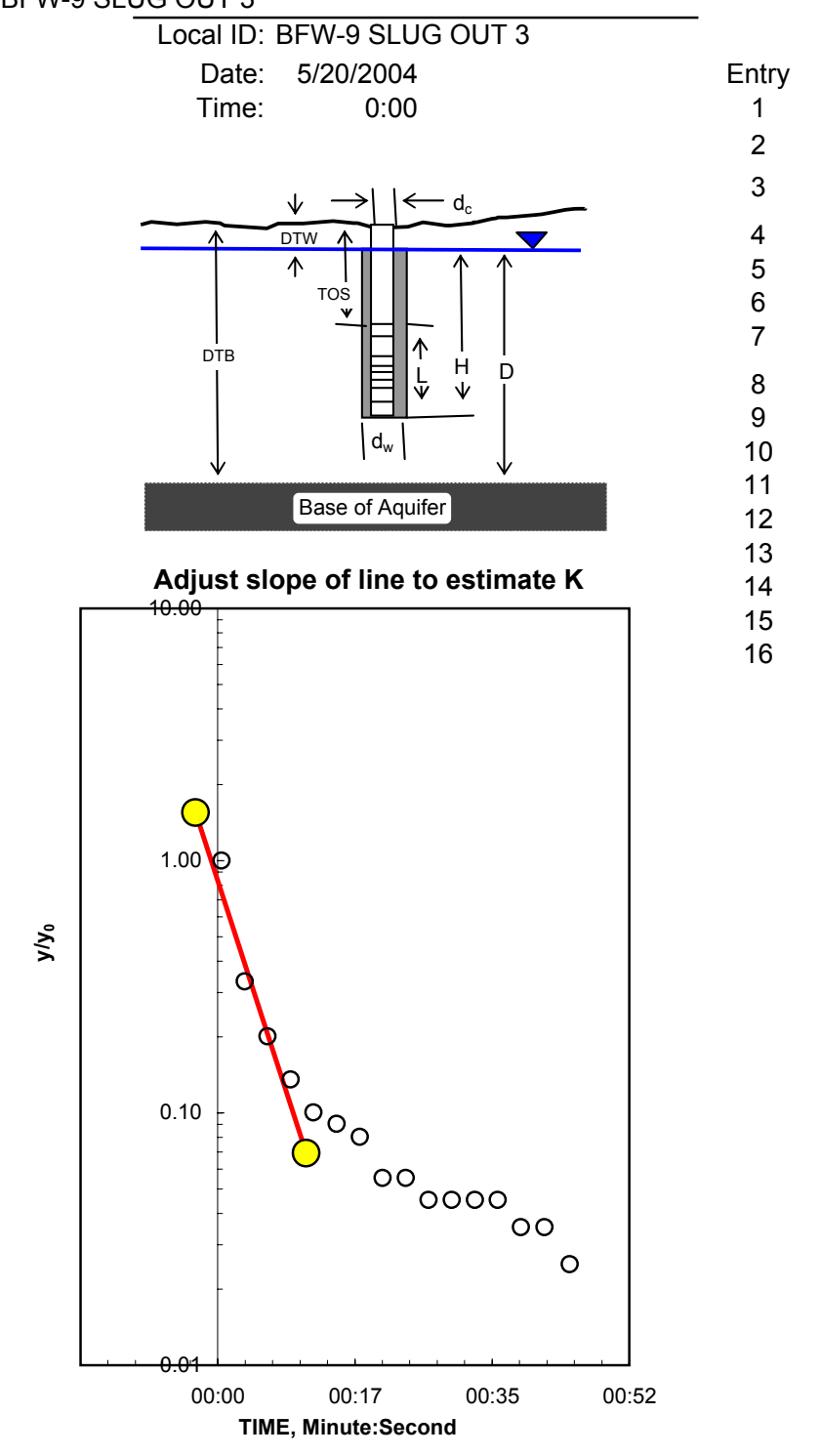

Reduced Data Time, Water Hr:Min:Sec Level $0: 00: 00.0 \quad 6.46$ $0: 00: 02.9 \quad 6.33$

$0: 00: 05.8 \quad 6.30$

$0: 00: 08.7 \quad 6.29$

$0: 00: 11.6 \quad 6.28$

$0: 00: 14.5 \quad 6.28$

$0: 00: 17.4 \quad 6.28$

$0: 00: 20.3 \quad 6.27$

$0: 00: 23.2 \quad 6.27$

$0: 00: 26.1 \quad 6.27$

$0: 00: 29.0 \quad 6.27$

$0: 00: 31.9 \quad 6.27$

$0: 00: 34.8 \quad 6.27$

$0: 00: 37.7 \quad 6.27$

$0: 00: 40.7 \quad 6.27$

$0: 00: 43.9 \quad 6.27$

REMARKS:

Farmville site, well BFW-9, slug out 3 assumed annulus dia 8.25

assumed slug length 3 ' 
Appendix 1E. Slug-test results for wells at the Farmville aquifer-test site in the Little Contentnea Creek basin, Pitt County, North Carolina, 2002-03. - Continued

WELL ID: BFW-10 SLUG OUT 2

\begin{tabular}{|c|c|}
\hline \multicolumn{2}{|c|}{ INPUT } \\
\hline \multicolumn{2}{|c|}{ Construction: } \\
\hline Casing dia. $\left(\mathrm{d}_{\mathrm{c}}\right)$ & 4 Inch \\
\hline Annulus dia. $\left(\mathrm{d}_{\mathrm{w}}\right)$ & 10.25 Inch \\
\hline Screen Length (L) & 10 Feet \\
\hline \multicolumn{2}{|l|}{ Depths to: } \\
\hline water level (DTW) & 6.91 Feet \\
\hline top of screen (TOS) & 5 Feet \\
\hline Base of Aquifer (DTB) & 15 Feet \\
\hline \multicolumn{2}{|c|}{ Annular Fill: } \\
\hline \multicolumn{2}{|c|}{$\begin{array}{c}\text { across screen -- Coarse Sand } \\
\text { above screen -- Bentonite }\end{array}$} \\
\hline \multicolumn{2}{|c|}{ Aquifer Material -- Medium Sand } \\
\hline \multicolumn{2}{|c|}{ COMPUTED } \\
\hline $\mathrm{L}_{\text {wetted }}$ & 8.09 Feet \\
\hline$D=$ & 8.09 Feet \\
\hline $\mathrm{H}=$ & 8.09 Feet \\
\hline $\mathrm{L} / \mathrm{r}_{\mathrm{w}}=$ & 18.94 \\
\hline $\mathrm{y}_{0 \text {-DISPLACEMENT }}=$ & 0.73 Feet \\
\hline $\mathrm{y}_{0-S L U G}=$ & 1.95 Feet \\
\hline \multicolumn{2}{|c|}{ From look-up table using $\mathrm{L} / \mathrm{r}_{\mathrm{w}}$} \\
\hline Fully penetrate $\mathrm{C}=$ & 1.683 \\
\hline $\ln (\operatorname{Re} / r w)=$ & 2.161 \\
\hline $\operatorname{Re}=$ & 3.71 Feet \\
\hline Slope $=$ & $0.033372 \log _{10} / \mathrm{sec}$ \\
\hline$t_{90 \%}$ recovery $=$ & $30 \mathrm{sec}$ \\
\hline \multicolumn{2}{|l|}{ Input is consistent. } \\
\hline $\begin{array}{l}\mathrm{K}= \\
\mathrm{T}=\end{array}$ & $\begin{array}{l}25 \text { Feet/Day } \\
200 \text { Feet2/Day }\end{array}$ \\
\hline
\end{tabular}

Local ID: BFW-10 SLUG OUT 2

Date: $\quad 5 / 20 / 2004$

Time: $\quad 0: 00$

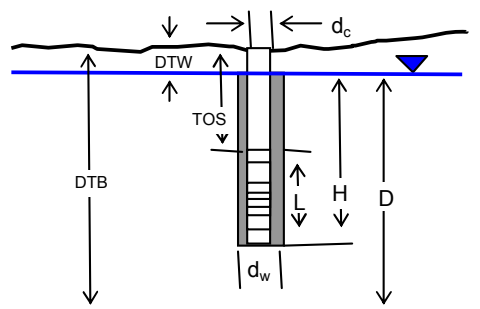

Base of Aquifer

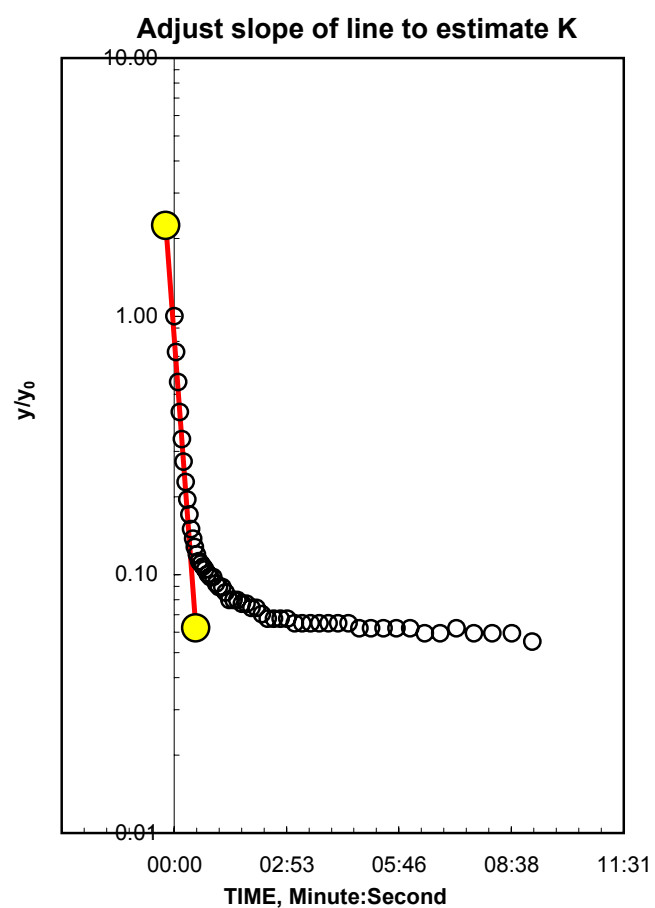

REMARKS:

Bouwer and Rice (1976) analysis of slug test
Reduced Data Time,

Hr:Min:Sec

0:00:00.0

0:00:02.9

0:00:05.8

0:00:08.7

0:00:11.6

$0: 00: 14.5$

0:00:17.4

0:00:20.3

0:00:23.2

0:00:26.1

0:00:29.0

$0: 00: 31.9$

$0: 00: 34.8$

$0: 00: 37.8$

$0: 00: 41.0$

$0: 00: 44.3$

$0: 00: 47.8$

$0: 00: 51.6$

$0: 00: 55.6$

0:00:59.8

0:01:04.3

0:01:09.0

0:01:14.0

0:01:19.4

0:01:25.0

0:01:30.9

$0: 01: 37.3$

$0: 01: 44.0$

$0: 01: 51.0$

$0: 01: 58.5$

0:02:06.5

0:02:14.9

0:02:23.9

$0: 02: 33.3$

$0: 02: 43.3$

0:02:53.9

0:03:05.2

0:03:17.1

0:03:29.7

0:03:43.0

0:03:57.2

$0: 04: 12.2$

0:04:28.1

0:04:44.9

0:05:02.7
Water

Level

7.64

7.44

7.31

7.22

7.15

7.11

7.08

7.05

7.03

7.02

7.01

7.00

7.00

6.99

6.99

6.99

6.99

6.98

6.98

6.98

6.98

6.98

6.98

6.97

6.97

6.97

6.97

6.97

6.97

6.96

6.96

6.96

6.96

6.96

6.96

6.96

6.96

6.96

6.96

6.96

6.96

6.96

6.96

6.96

6.96 
Appendix 1E. Slug-test results for wells at the Farmville aquifer-test site in the Little Contentnea Creek basin, Pitt County, North Carolina, 2002-03. - Continued

WELL ID: BFW-11 SLUG OUT 3

\begin{tabular}{|c|c|}
\hline \multicolumn{2}{|c|}{ INPUT } \\
\hline \multicolumn{2}{|l|}{ Construction: } \\
\hline Casing dia. $\left(\mathrm{d}_{\mathrm{c}}\right)$ & 2 Inch \\
\hline Annulus dia. $\left(\mathrm{d}_{\mathrm{w}}\right)$ & 8.25 Inch \\
\hline Screen Length (L) & 10 Feet \\
\hline \multicolumn{2}{|l|}{ Depths to: } \\
\hline water level (DTW) & 6.99 Feet \\
\hline top of screen (TOS) & 5.05 Feet \\
\hline Base of Aquifer (DTB) & 15.05 Feet \\
\hline \multicolumn{2}{|c|}{ Annular Fill: } \\
\hline \multicolumn{2}{|c|}{$\begin{array}{c}\text { across screen -- Fine Sand } \\
\text { above screen -- Bentonite }\end{array}$} \\
\hline \multicolumn{2}{|c|}{ Aquifer Material -- Medium Sand } \\
\hline \multicolumn{2}{|c|}{ COMPUTED } \\
\hline $\mathrm{L}_{\text {wetted }}$ & 8.06 Feet \\
\hline$D=$ & 8.06 Feet \\
\hline$H=$ & 8.06 Feet \\
\hline $\mathrm{L} / \mathrm{r}_{\mathrm{w}}=$ & 23.45 \\
\hline $\mathrm{y}_{0 \text {-DISPLACEMENT }}=$ & 0.14 Feet \\
\hline $\mathrm{y}_{0-S L U G}=$ & 0.75 Feet \\
\hline \multicolumn{2}{|c|}{ From look-up table using $\mathrm{L} / \mathrm{r}_{\mathrm{w}}$} \\
\hline Fully penetrate $\mathrm{C}=$ & 1.857 \\
\hline $\ln (\operatorname{Re} / r w)=$ & 2.337 \\
\hline $\operatorname{Re}=$ & 3.56 Feet \\
\hline Slope $=$ & $0.128008 \log _{10} / \mathrm{sec}$ \\
\hline $\mathrm{t}_{90 \%}$ recovery $=$ & $8 \mathrm{sec}$ \\
\hline \multicolumn{2}{|l|}{ Input is consistent. } \\
\hline $\begin{array}{l}\mathrm{K}= \\
\mathrm{T}=\end{array}$ & $\begin{array}{c}26 \text { Feet/Day } \\
210 \text { Feet2/Day }\end{array}$ \\
\hline
\end{tabular}

Local ID: BFW-11 SLUG OUT 3

$$
\text { Date: } 5 / 20 / 2004
$$$$
\text { Time: } \quad 0: 00
$$

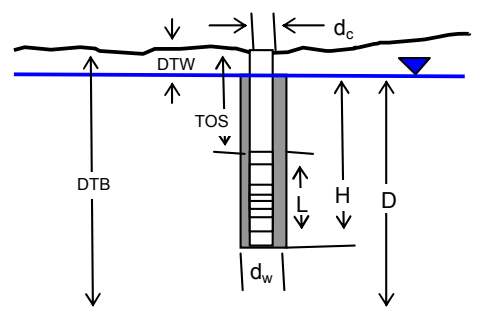

Base of Aquifer

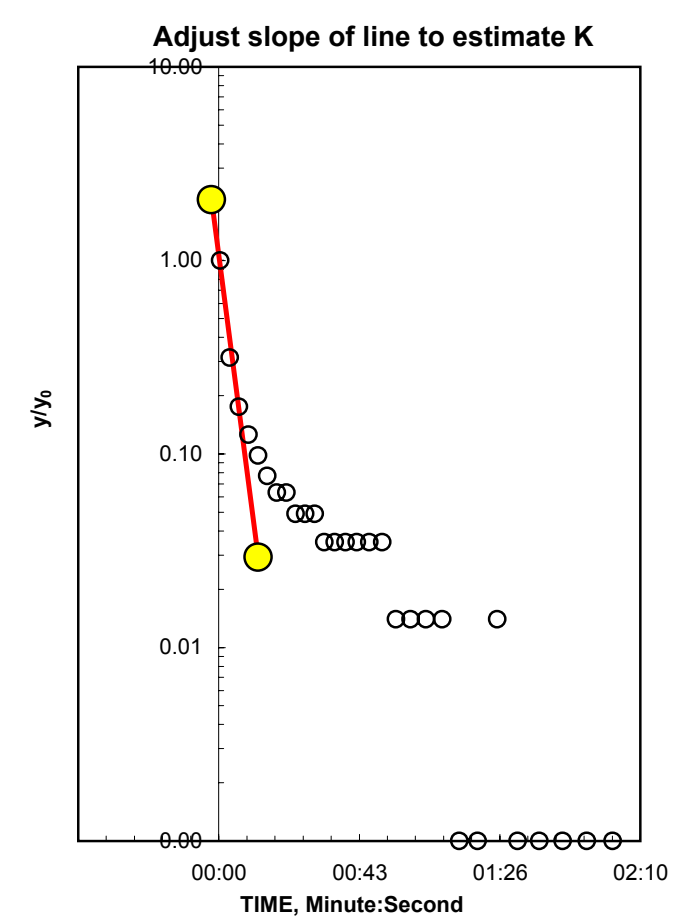

Reduced Data Time, Water

Hr:Min:Sec Level 0:00:00.0 $\quad 7.21$

0:00:02.9 $\quad 7.12$

0:00:05.8 $\quad 7.10$

0:00:08.7 $\quad 7.09$

$0: 00: 11.6 \quad 7.08$

0:00:14.5 $\quad 7.08$

$0: 00: 17.4 \quad 7.08$

0:00:20.3 $\quad 7.08$

$0: 00: 23.2 \quad 7.08$

0:00:26.1 $\quad 7.08$

0:00:29.0 $\quad 7.08$

$0: 00: 32.0 \quad 7.08$

0:00:35.2 $\quad 7.08$

$0: 00: 38.5 \quad 7.08$

$0: 00: 42.1 \quad 7.08$

$0: 00: 45.8 \quad 7.08$

0:00:49.8 $\quad 7.08$

0:00:54.0 $\quad 7.07$

0:00:58.5 $\quad 7.07$

0:01:03.2 $\quad 7.07$

0:01:08.2 $\quad 7.07$

0:01:13.6 $\quad 7.07$

0:01:19.2 $\quad 7.07$

0:01:25.1 $\quad 7.07$

0:01:31.5 $\quad 7.07$

$0: 01: 38.2 \quad 7.07$

$0: 01: 45.2 \quad 7.07$

0:01:52.8 $\quad 7.07$

REMARKS:

Bouwer and Rice (1976) analysis of slug test

Farmville site, well BFW-11, slug out 3 assumed annulus dia 8.25

assumed slug length 3 ' with 1.0 " diameter. 


\section{总}

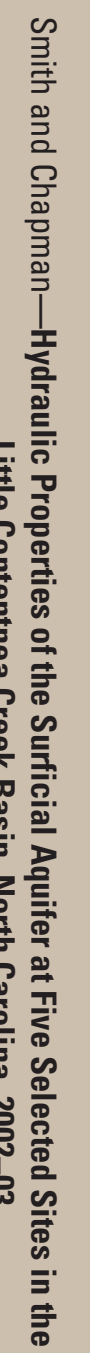

6 Printed on recycled paper

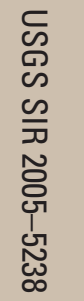

